\title{
Gender and the Genocide in Rwanda
}

This book examines the mobilization, role, and trajectory of women rescuers and perpetrators during the 1994 genocide in Rwanda.

While much has been written about the victimization of women during the 1994 genocide in Rwanda, very little has been said about women who rescued targeted victims or perpetrated crimes against humanity. This book explores and analyzes the role played by women who exercised agency as rescuers and as perpetrators during the genocide in Rwanda. As women, they took actions and decisions within the context of a deeply entrenched patriarchal system that limited their choices.

This work examines two diverging paths of women's agency during this period: to rescue from genocide or to perpetrate genocide. It seeks to answer three questions: First, how were certain Rwandan women mobilized to participate in genocide, and by whom? Second, what were the specific actions of women during this period of violence and upheaval? Finally, what were the trajectories of women rescuers and perpetrators after the genocide? Comparing and contrasting how women rescuers and perpetrators were mobilized, the actions they undertook, and their post-genocide trajectories, and concluding with a broader discussion of the long-term impact of ignoring these women, this book develops a more nuanced and holistic view of women's agency and the genocide in Rwanda.

This book will be of interest to students of gender studies, genocide studies, African politics and critical security studies.

Sara E. Brown is a Fellow at the USC Shoah Foundation - The Institute for Visual History and Education, and has a PhD in Comparative Genocide Studies from Clark University, USA. 


\author{
Routledge Studies in Gender and Security \\ Series editors: Laura Sjoberg \\ University of Florida \\ and \\ Caron E. Gentry \\ University of St. Andrews
}

This series looks to publish books at the intersection of gender studies, international relations, and security studies. It will publish a broad sampling of work in gender and security - from private military companies to world wars, from food insecurity to battlefield tactics, from large-n to deconstructive, and across different areas of the world. In addition to seeking a diverse sampling of substantive work in gender and security, the series seeks a diverse author pool looking for cutting-edge junior scholars alongside more established authors, and authors from a wide variety of locations and across a spectrum of backgrounds.

\title{
Gender and the Genocide in Rwanda
}

Women as Rescuers and Perpetrators

Sara E. Brown 


\title{
Gender and the Genocide in Rwanda \\ Women as Rescuers and Perpetrators
}

\author{
Sara E. Brown
}


First published 2018

by Routledge

2 Park Square, Milton Park, Abingdon, Oxon OX14 4RN

and by Routledge

711 Third Avenue, New York, NY 10017

Routledge is an imprint of the Taylor \& Francis Group, an informa business

(C) 2018 Sara E. Brown

The right of Sara E. Brown to be identified as author of this work has been asserted by her in accordance with sections 77 and 78 of the Copyright, Designs and Patents Act 1988.

The Open Access version of this book, available at www.taylorfrancis.com, has been made available under a Creative Commons Attribution-Non Commercial-No Derivatives 4.0 license.

Trademark notice: Product or corporate names may be trademarks or registered trademarks, and are used only for identification and explanation without intent to infringe.

British Library Cataloguing-in-Publication Data

A catalogue record for this book is available from the British Library

Library of Congress Cataloging-in-Publication Data

A catalog record for this book has been requested

ISBN: 978-1-138-04353-4 (hbk)

ISBN: 978-1-315-17307-8 (ebk)

Typeset in Times New Roman

by Wearset Ltd, Boldon, Tyne and Wear 
In honor of Morton and Pauline Kleinman, and in memory of the Rwandans who lost their lives as a result of the genocide. 



\section{Contents}

Acknowledgments viii

List of abbreviations ix

Introduction: A Study in Contrasts

1 Finding the Right Flashlight: Frames of Analysis and Review of Literature 5

2 History of Rwanda 23

3 Mobilization and Militarization 39

4 Rescuers $\quad 59$

5 Perpetrators 91

6 Post-Genocide Trajectories 121

7 Sharing Salt 145

$\begin{array}{ll}\text { Epilogue } & 161\end{array}$

Appendix A: Ethnographic interview questions for community and government stakeholders 165

Appendix B: Semi-structured interview questions for individuals who are survivors, witnesses, rescuers, or perpetrators 167

$\begin{array}{ll}\text { Glossary } & 169\end{array}$

$\begin{array}{ll}\text { Index } & 170\end{array}$ 


\section{Acknowledgments}

This book first took shape as my doctoral dissertation and was made possible thanks to many individuals. First and foremost, I am grateful to the Stern family for its generous support of this research. I thank Debórah Dwork from the bottom of my heart for her unflagging mentoring, guidance, and support. Heartfelt thanks to Cynthia Enloe and David Simon for their feedback, counsel, and encouragement.

I am thankful for the Clark University community and everyone who saw me through my undergraduate years and into my doctoral studies. Thanks to Barbara Harff, Yehuda Bauer, Marion Pritchard, Shelly Tenenbaum, Kristen Williams, Taner Akçam, Ken MacLean, Mary Jane Rein, Marianne Sarkis, Cynthia Fenner, Jean Hearns, and my center classmates and colleagues. I also thank the staff at the Interdisciplinary Center, Galia Golan and Isaac Kfir in particular. Thanks too to Mike Auman for his patient mentoring.

Murakoze canye to Susan Mbabazi for her research, translation assistance, and friendship. Thanks to Christian Alain Bizimana and Sharon Batamuriza who assisted me with my research. Thanks also to Marlene Bellamy for her careful editing on earlier drafts and thoughtful advice.

Murakoze to Jean-Damascène Gasanabo at the CNLG Research and Documentation Center on Genocide, Odeth Kantengwa, Omar Ndiyeze, Usta Kaitesi, Odette Kayirere at AVEGA Agahozo, James Smith, John Petrie, and the staff at the Kigali Genocide Memorial (KGM) and Genocide Archive of Rwanda, and the staff at the Gacaca Court Archives.

My family served as my emotional backbone throughout this process. Thank you to my mother and lifelong editor and guide, Babs, and to my brother and best friend Josh and his family for their love and support. Thank you to my grandparents, who instilled in me the value of education. Thank you to Yannick Tona for joining my family later in life and inspiring much of my research. Thanks also to the Nahmias/Kurta family for opening their hearts and homes to me.

Special thanks to my husband, Elliott, who committed to this journey with me, never gave up on me, and never let me give up.

Finally, warm thanks to the individuals who agreed to participate in this study. Without you, this book would not exist. Imana ibahe umugisha kandi ibane namwe. 


\section{Abbreviations}

$\begin{array}{ll}\text { AERG } & \text { Association des Etudiants et Éleves Rescapés Du Genocide } \\ \text { AOCM } & \text { Association des Orphelins Chefs de Ménages } \\ \text { AVEGA } & \text { Association des Veuves du Genocide or the Association of the } \\ & \text { Widows of Genocide } \\ \text { CDR } & \text { Coalition pour la Défense de la République } \\ \text { FAR } & \text { Forces Armées Rwandaises } \\ \text { HAGARUKA } & \text { Association for the Defense of Women and Children's Rights } \\ \text { ICTR } & \text { International Criminal Tribunal for Rwanda } \\ \text { MRND } & \text { Mouvement Révolutionnaire National pour le Développement } \\ & \text { (before 1991) } \\ \text { MRNDD } & \text { Mouvement Républicain National pour la Démocratie et le } \\ & \text { Développement (after 1991) } \\ \text { NPS } & \text { National Prison Service } \\ \text { RPF } & \text { Rwandan Patriotic Front, referred to in slang as Inkotanyi } \\ \text { RTLM } & \text { Radio Télévision Libre des Mille Collines } \\ \text { TIG } & \text { Travaux d'Intérêt Général or Works for General Interest }\end{array}$





\title{
Introduction
}

\author{
A Study in Contrasts
}

At a TIG internment camp in Muhanga district, Rwanda, Suzanne, an elderly Hutu woman with cataracts, clutched her white plastic rosary as she spoke. At the time, she was serving a 12-year sentence for participating in the 1994 Genocide against the Tutsi genocide in Rwanda. ${ }^{1}$ She launched into her story. "The reason why I'm here is because I'm accused, I actually killed my grandson, one of my grandkids during the war. That's why I came here."2 The details unfolded in fits and starts. In 1994, Suzanne lived with her husband, her daughter, and two grandchildren who were the product of her daughter's relationship with a Tutsi man from whom she had since separated. When Suzanne began to describe the genocide, she offered differing versions of what proceeded. But what remained constant was that at some point during the genocide, Suzanne and her husband had helped their daughter kill at least one of her children due to its ethnically mixed parentage.

Further south, near Murambi, Rwanda, Wendy, a religious mother of three, sat in her living room and recounted her heroic acts quietly. This unassuming woman chose a different trajectory when the genocide began. When a Tutsi family fleeing the killings arrived at her doorstep, she immediately offered them refuge in her home. She did not waver though she knew the risks she incurred by rescuing Tutsis. If she were caught, she would likely be murdered. Asked what prompted her to rescue while so many of her neighbors stood by or, worse, perpetrated genocide, she grew indignant, asserting that her readiness to help was the only conceivable response. ${ }^{3}$

Gender and the Genocide in Rwanda: Women as Rescuers and Perpetrators explores and analyzes the central role played by women who exercised agency as rescuers and as perpetrators during the genocide in Rwanda in 1994. Much of the existing genocide studies literature focuses on rescue or perpetration in an effort to determine how and why individuals took action during genocide. Few texts compare and contrast between these diverging expressions of agency, and even fewer focus on women and their unique experience as actors during genocide. But as women in 1994 Rwanda, they took actions and decisions within the unique context of a deeply entrenched patriarchal system that limited their agency. Thus Gender and the Genocide in Rwanda deliberately examines these two diverging paths of women's constrained agency during this period of intense communal violence: to rescue from genocide or to perpetrate genocide. 


\section{Introduction}

While much has been written about the victimization of women, ${ }^{4}$ most of the literature does not scrutinize women who rescued targeted victims of the genocide in Rwanda or perpetrated crimes against humanity. Women are traditionally cast as victims during mass violence, and indeed many women do suffer horrific sex-specific abuse and violence. This was certainly the case in Rwanda where the United Nations Special Rapporteur of the Commission on Human Rights, René Degni-Ségui, estimated that between 250,000 and 500,000 women were targeted for rape in $1994 .{ }^{5}$ But, as noted by author Chimamanda Ngozi Adichie, "The single story creates stereotypes, and the problem with stereotypes is not that they are untrue, but that they are incomplete. They make one story become the only story." This gender-based characterization of Rwandan women thus elides women who exercised agency and became rescuers or perpetrators.

Gender and the Genocide in Rwanda seeks to answer three core sets of questions. First, how were certain Rwandan women mobilized and militarized to participate in genocide, and by whom? A series of sub-questions flows from this main question: How were some women galvanized to commit atrocities while others took a stand against them, becoming, to use the former United States Ambassador to the United Nations, Samantha Power's term, "upstanders"? What was the role of the media, leadership, and key individuals in preparing the ground for some women's involvement in committing mass atrocities? My second question pertains to the specific actions of women who exercised agency during this period of violence and upheaval. Women's participation in acts of rescue or genocidal violence was widespread though not uniform, and their actions, feelings, and strategies during this period are largely unknown. Finally, I trace what happened to these women rescuers and perpetrators in the aftermath of the genocide. Was their role recognized and acknowledged by the local population, country, and broader international community? Were rescuers hailed as heroes and perpetrators brought to justice?

Comparing and contrasting how women rescuers and perpetrators were mobilized and militarized, the actions they undertook, and their post-genocide trajectories, I aim to develop a more nuanced and holistic view of women's agency and the genocide in Rwanda.

\section{Narrative structure}

Moving beyond commonly held assumptions, Gender and the Genocide in Rwanda: Women as Rescuers and Perpetrators examines how, during the genocide, the traditional gendered role of women broke down alongside the rule of law and state institutions. Focusing on the role and agency of women immediately before and during the genocide, Gender and the Genocide in Rwanda concludes with an analysis of the post-genocide trajectory of these women's lives, and the continuing impact of that trajectory on Rwandan society.

Chapter 1, "Finding the Right Flashlight," outlines the theoretical framework of Gender and the Genocide in Rwanda, assessing relevant bodies of literature. It defines and contextualizes key terms specific to the genocide and details the 
research methodology utilized. Chapter 2, "History of Rwanda," analyzes the underlying social, political, and patriarchal structures in Rwanda, spanning its pre-colonial, colonial, and independence periods. It examines how the transition to colonial indirect rule, first under the Germans and, most notably, under the Belgians, led to upheaval in Rwandan society, changing gender norms, and a subsequent shift in the nexus of power. It then traces Rwanda's postindependence trajectory and the intersecting influence and impact of sex-based and ethnic relations to trace developments that directly and indirectly contributed to the role of women during the 1994 genocide.

Chapter 3, "Mobilization and Militarization," moves to the events leading to the genocide in Rwanda, exploring how the population, most notably the women, was mobilized and self-mobilized. It drills down on the role of the media, leadership, and key individuals as the country descended into mass violence, setting the stage for genocide. Chapter 3 also compares and contrasts the reactions of women rescuers and perpetrators to these efforts, and how these processes persisted throughout the genocide. Chapters 4, "Rescuers," and 5, "Perpetrators," focus on the myriad actions, experiences, and strategies employed by women rescuers and perpetrators during the genocide. These chapters plumb women's motivations, thoughts, and feelings during the genocide. While there is no singular narrative or experience for women rescuers or perpetrators, certain recurring themes contribute to our better understanding the role and actions of women rescuers and perpetrators.

The lives of women rescuers and perpetrators continued after the genocide, and Chapter 6, "Post-Genocide Trajectories," traces their diverging and converging courses over the next 20 years. It analyzes the impact of gendered insecurity experienced by many women rescuers and the overwhelming anonymity women perpetrators initially enjoyed. The final chapter, Chapter 7, "Sharing Salt," concludes with a broader discussion of the importance and impact of this gendered silence on reconciliation initiatives in Rwanda and on women rescuers and perpetrators. Broadly, it addresses the negative implications of a gender-based impunity-by-attrition culture on reconstruction and rehabilitation.

Gendered assumptions about women's agency and conduct during the genocide in Rwanda ignore the fact that many Tutsis attribute their survival to the efforts of brave women who risked their lives to assist them. And it ignores the thousands of women tried for crimes committed during the genocide, many of whom are serving sentences in jails throughout the country. Gender and the Genocide in Rwanda attempts to fill a lacuna in the literature. In 1994's Rwanda, women could be mothers, wives, daughters, sisters, and rescuers or perpetrators; these roles were not and are not mutually exclusive. Though fewer in number than the men who acted during the genocide, and though marginalized socially and economically within Rwandan society, the women who exercised agency during the genocide in Rwanda were significant, and their participation and its continued impact on Rwanda today are the primary focus of this study. 


\section{Introduction}

\section{Notes}

1 Also referred to as "the genocide" or "the genocide in Rwanda."

2 Interview G 2 "Suzanne," interview by Sara E. Brown, Muhanga, Rwanda, 30 June 2011.

3 Interview R 2 "Wendy," interview by Sara E. Brown, Murambi, Rwanda, 28 June 2011.

4 For example, inter alia, Anne-Marie de Brouwer and Sandra Ka Hon Chu (eds.), The Men Who Killed Me: Rwandan Survivors of Sexual Violence (Toronto: Douglas \& McIntyre, 2009); Jennie E. Burnet, Genocide Lives in Us: Women, Memory, and Silence in Rwanda (Madison: University of Wisconsin Press, 2012); Llezlie L. Green, "Propaganda and Sexual Violence in the Rwandan Genocide: An Argument for Intersectionality in International Law," Columbia Human Rights Law Review 33 (Summer 2002): 733-76; Donatilla Mukamama and Petra Brysiewicz, "The Lived Experience of Genocide Rape Survivors in Rwanda," Journal of Nursing Scholarship 40, no. 4 (2008): 379-84; Binaifer Nowrojee, "Shattered Lives: Sexual Violence during the Rwandan Genocide and its Aftermath," Human Rights Watch (September 1996); Christopher Taylor, Sacrifice as Terror: The Rwandan Genocide of 1994 (Berg: Oxford International, 1999); and Samuel Totten (ed.), Plight and Fate of Women During and Following Genocide (New Brunswick: Transaction Publishers, 2012).

5 René Degni-Ségui, "Question of the Violation of Human Rights and Fundamental Freedoms in any Part of the World, with Particular Reference to Colonial and Other Dependent Countries and Territories: Report on the Situation of Human Rights in Rwanda," United Nations Economic and Social Council, 29 January 1996.

6 Chimamanda Ngozi Adichie, "The Danger of a Single Story,” TED Talk, July 2009.

\section{References}

Adichie, Chimamanda Ngozi. “The Danger of a Single Story.” TED Talk. July 2009.

Degni-Ségui, René. "Question of the Violation of Human Rights and Fundamental Freedoms in any Part of the World, with Particular Reference to Colonial and Other Dependent Countries and Territories: Report on the Situation of Human Rights in Rwanda." United Nations Economic and Social Council. 29 January 1996.

Interview G 2 "Suzanne." Interview by Sara E. Brown. Muhanga, Rwanda. 30 June 2011. Interview R 2 "Wendy." Interview by Sara E. Brown. Murambi, Rwanda, 28 June 2011. 


\section{Finding the Right Flashlight \\ Frames of Analysis and Review of Literature}

Feminist scholar J. Ann Tickner writes that "too often women's experiences have been deemed trivial, or important only in so far as they relate to the experiences of men." Gender and the Genocide in Rwanda offers a new approach to women's agency during genocide and is rooted in a multi-disciplinary theoretical framework informed by feminist theory, comparative historical analysis, comparative genocide studies, and constructivism and sociology. This interdisciplinary approach builds on feminist theorist Cynthia Enloe's advice.

I find it helpful to judge the usefulness of any concept in the same way that I judge a flashlight. Someone hands you a flashlight and you say, "I wonder if it is a good flashlight." So you go into a darkened room, you turn it on, and you judge if corners of the room previously in the shadows now become easier to see than before. If you find that this particular flashlight distorts the shapes in the room or if the beam is too weak and you still trip over objects on the floor, then you return that flashlight with a polite "thank you."

Feminist theory opens questions that help us understand women's agency during genocide and J. Ann Tickner's body of work in particular elucidates the gendered frame of the genocide in Rwanda. Feminist sociologist Cynthia Cockburn asserts that, "A gender analysis alerts us to an intentionality in differentiation between the sexes. It also makes us hesitate to take at face value other distinctions...." According to Tickner, "there is a hierarchy of masculinities in which gender interacts with class and race" ${ }^{4}$ and, in the Rwandan case, ethnicity. In order to fully examine the role of women during the genocide in Rwanda, I ask questions inspired by Enloe, including "Where are the women?"; "How did they get there?"; "What are they doing?" and "Why?" In order to capture the voices of women, I collect and analyze oral histories; as gender and conflict expert Erin Baines notes, "life stories are a particularly useful method to shed insight into the social positions of oppressed groups within a given institution and historical setting, to comprehend human agency, motivation, and choice." ${ }^{5}$ Oral histories shed light on human agency, thinking, feeling, and behavior. Using Tickner's construct and grounding my research in oral histories, Gender and the Genocide in Rwanda lays bare the gendered foundations of the genocide in Rwanda and 


\section{Finding the Right Flashlight}

women's agency, including limitations and particularities, in order to understand the invisibility of women's narratives during the genocide in Rwanda. ${ }^{6}$

Feminist theory also helps us grasp how human agency is simultaneously social and individual; international and personal. ${ }^{7}$ Enloe asserts that the personal is international and vice versa, and that the invisibility of women and the silence that surrounds them during conflict stems from the home and expands into the international sphere. ${ }^{8}$ At the same time, the international community perpetuates a masculinized interpretation of conflict that denies women a role in the violence aside from that of victim or bystander. Educational psychologist David Moshman writes about the conceptual lens through which genocide is analyzed and the flaws inherent in subjective conceptual thought. ${ }^{9}$ Redirecting Moshman's theory to examine gendered narratives of genocide, the conceptual lens through which genocide is researched, reported on, documented, and (ideally) prevented often ignores women's agency and typecasts women as passive victims or bystanders. These gendered concepts through which scholars examine the genocide in Rwanda are therefore informed by Moshman's analysis of subjectivity in conceptual structures; gendered concepts and their resulting biases are largely invisible and therefore go unacknowledged. Due to this invisible gendered lens, most scholars, humanitarians, and interested individuals who study the genocide in Rwanda see men as perpetrators or victims and women as victims or bystanders. There is little space to explore women as rescuers or as perpetrators; as noted by Adler et al, "Genocide is more often than not characterized as a male crime, the outcome of contemporary notions of masculinity." 10

This denial of agency (which extends into the personal realm) prompts me to re-examine the myth of women's pacifism. With a few notable exceptions, women agents are typically overlooked because of gendered assumptions, often supported by otherwise impressive scholarship, about "inherent pacifism" that are essentialist and flawed. ${ }^{11}$ If history is any indication, women are capable of acts of belligerence and of heroism. A group of key works address women's participation in violent social movements. Sociologist Kathleen Blee explores in Women of the Klan the recruitment and involvement of women in the $\mathrm{Ku}$ Klux Klan in the 1920s. ${ }^{12}$ The constrained and gendered participation of women is also addressed by historian Claudia Koonz's Mothers in the Fatherland. Her study sheds light on women's contributions to the Nazi party and their subjugation to the patriarchal foundations of the fascist regime. ${ }^{13}$ The motivations, actions, and fate of women perpetrators during the Holocaust are further scrutinized by historian Wendy Lower in Hitler's Furies. Her analysis further emphasizes the ordinary nature of women Nazis. ${ }^{14}$ These groundbreaking works laid the foundation for the conversation this study endeavors to join. Gender and the Genocide in Rwanda also addresses more broadly the small but growing body of literature that explores women as combatants and armed insurgents. ${ }^{15}$

Still, gendered assumptions about the pacifism of women persist in scholarly discourse, muting discussion of women's agency and capacity for violence in pursuit of rescue or murder. To move research beyond readily available statistics that reinforce gendered generalizations requires methods for "studying silences," 
the title of Annica Kronsell's 2006 article ${ }^{16}$ Kronsell offers techniques for looking beyond gendered practices and overcoming the absence of readily available data. Ackerly et al. also write about studying silences, asserting that doing so "means that the research has to rely on methods of deconstruction." ${ }^{17}$ Due to the gendered invisibility of women during times of violent upheaval, unless given visibility as victims, silence shrouds their motivations, actions, and experiences post-violence. In instances when a spotlight is cast upon women who participate in violence, they are "othered," denied "both agency and womanhood," and cast into gender-specific typecasts such as the "mother, monster, whore" narratives explored by Laura Sjoberg and Caron Gentry. ${ }^{18}$ As a result of a combination of these and specific gendered processes particular to Rwandan culture, the full scope of agency exhibited by women rescuers and perpetrators during the genocide in Rwanda remains uncharted, along with how their agency was performed and under what types of socially (and inherently masculine) prescribed constraints.

Women's constrained agency during the genocide was in part a result of deliberate gendered mobilization that normalized violence against Tutsi women. Research by feminist scholars Andrea Dworkin and Catherine MacKinnon on the role of pornography in normalizing violence against women helps to frame in broader terms the treatment of women during the genocide in Rwanda. ${ }^{19}$ It contextualizes the extremist literature and pornographic cartoons that targeted Tutsi women prior to and during the 1994 genocide as part of a process of hypersexualization and dehumanization that catalyzed violence against Tutsi women, sometimes at the hands of Hutu women. This hyper-sexualization of African women has its roots in a colonial combination of sexual repression, exoticism, and racism that existed in white Europe at the turn of the twentieth century. ${ }^{20}$ Feminist scholar Jan J. Pettman noted how following colonization many of these "racialized gender stereotypes [that] frequently represented colonized women as promiscuous and exotic" were adopted and adapted in Rwanda to include ethnicity as another boundary-marker of the "other", and catalyzed violence against Tutsi women during the genocide. ${ }^{21}$

If feminist theory serves as the backbone of this study, scholarship on the role of the individual as victim, bystander, perpetrator, or "upstander" during conflict further develops Gender and the Genocide in Rwanda. Research by Ervin Staub and James Waller examine individual and group motivations for horrific crimes, while Victoria Barnett explores the development and importance of bystanders during the Holocaust. ${ }^{22}$ As there is little scholarship on rescue in Rwanda, and none on women rescuers, Gender and the Genocide in Rwanda relies heavily on research on rescue during the Holocaust. Staub offers an answer to his own quandaries, examining in Overcoming Evil: Genocide, Violent Conflict, and Terrorism how to develop a culture of upstander-ship in instances of mass violence. He provides a lens of analysis for those who rescue that is supported by Samuel and Pearl Oliner's work on altruism, and Nechama Tec's research on rescuers and resisters during the Holocaust. ${ }^{23}$ Gender and the Genocide in Rwanda also reflects the influence of Dr. Marion Pritchard, a rescuer during the Holocaust 


\section{Finding the Right Flashlight}

who candidly described the layers of complexity, struggle, and identity inherent in a single rescuer.

Still, most of the scholarship on the genocide in Rwanda focuses on menperpetrated crimes. These include, for example, Jean Hatzfeld's excellent documentation of convicted genocide-perpetrator testimonies and Scott Straus's groundbreaking empirical analysis of genocide perpetrators. Crimes committed by women are mentioned in passing, relevant only in relation to the crimes of men. ${ }^{24}$ This gender-exclusive oversight risks erasing women perpetrators from the supra-narrative of the genocide and is consistent with the ideological constraints that have conditioned "Western views of African women's history" according to historian Christina Saidi. ${ }^{25}$ The first two conditions address the prioritization of women as wives, with considerably less importance given to the roles of mother and sister, and the imposition of the western version of the nuclear family, which ignores women's relationship with her own lineage. The third assumption, "the universally subordinate position of women during all historical periods," ${ }^{26}$ is particularly salient here. In other instances, women have been mentioned in the literature, but as subordinates and in a subsidiary role. Political scientist Mahmood Mamdani briefly notes women's participation during the genocide, albeit in an auxiliary role squarely behind men, "like the second line in a street-to-street battle." ${ }^{27}$ The majority of the crimes committed during the genocide were indeed perpetrated by men; yet, the silence about women's agency undermines the value of existing analyses.

Non-governmental and inter-governmental bodies have furthered this gendered stratification, publishing reports that affirm gendered stereotypes of women's passivity with the occasional, almost offhand, mention of women who participated in the genocide. The United Nations Economic and Social Council's "Report on the situation of human rights in Rwanda" noted that,

It is true that a number of women took part in the genocide and other crimes against humanity. Most, however, were rather the victims. They may even be regarded as the main victims of the massacres, with good reason, since they were raped and massacred and subjected to other brutalities. ${ }^{28}$

In this report, while women's participation in the genocide is acknowledged with one line, it is then overshadowed by three pages dedicated to women victims and no mention of women rescuers. This limited, monolithic narrative overlooks a more complicated (and, for some, uncomfortable) analysis of women during the genocide in Rwanda. And as was aptly noted by Chimamanda Ngozi Adichie during her TED Talk in 2009, "that is how to create a single story. Show a people as one thing over and over again and that is what they become. It is impossible to talk about the single story without talking about power." 29 The limited literary "real estate" afforded to women during the genocide in Rwanda narrows the focus to women victims, their vulnerability, and their systematic victimization, and stymies a more-nuanced examination of women's experiences during the genocide. Women are given a finite amount of space in the narrative 
and so their stories are simplified and amalgamated into the category of "victimhood" because anything more nuanced would require space, time, and effort. Equally significant, such narratives would challenge existing masculinized interpretations of genocide. This extends into broader analysis of international security; as noted by political scientist Jonathan Wadley,

The silencing of agency, the restriction of movement, the claiming of knowledge about threats that the protected do not possess - when viewed in relation to dominant forms of masculinity, it is apparent that such performances establish not only asymmetric relations, but relations that are asymmetric because of their relations to gender norms. ${ }^{30}$

And while there is a degree of acceptance of women's agency during the genocide within Rwanda's borders, it is balanced by a perception of the essentialized woman according to loaded gender norms.

The complicated story is necessary. It is needed to document, learn from, and prevent mass violence. And it is needed to return to Rwandan women their identities, their personhood, and their narrative. A feminist analysis of genocide does not prioritize feminism over the horrific event or mitigate its lasting impact. Rather, feminism is a tool or a lens to better understand genocide. In a volume on women during the Holocaust, editors Dalia Ofer and Lenore Weitzman correctly asserted that the scholarship they presented did not "make the Holocaust secondary to feminism." 31 Instead, such research serves to "enhance our understanding of it [the Holocaust] by locating it in the specificity of individual experiences." 32 In other words, a feminist analysis of the varied modes of women's participation only adds to our understanding of the genocide in Rwanda and constitutes a key piece of the whole and complicated story.

Gender and the Genocide in Rwanda contributes to the small body of work that addresses women who employ violence or facilitate necessary conditions for the perpetration of violence, their crimes, and their reception by society. Specific to Rwanda, in 1995 a report published by the human rights non-governmental organization African Rights, Rwanda: Not So Innocent - When Women Become Killers, was the first to challenge the dominant narrative. Documenting numerous instances of woman-perpetrated genocide as recounted by survivors and witnesses, the report asserts that "women and girls have been described as the principal victims of the genocide in Rwanda, thus obscuring the role of women as aggressors." 33 Several years later, Lisa Sharlach's research diverges from the traditional male-centric documentation of the genocide in Rwanda and focuses on women as participants in the genocide, rather than victims of the violence. An innovative study, its publication preceded the inauguration and completion of the Gacaca courts, a judicial body in Rwanda that tried over one million suspected genocidaires. She emphasizes that "few in the West realize the extent to which women participated in the Rwandan genocide." ${ }^{34}$ Sjoberg and Gentry (Mothers, Monsters, Whores) address case studies of women-perpetrated violence during the genocide in Rwanda, including the influential role of Pauline 
Nyiramasuhuko, minister in the Rwandan government and mother-in-law of Beatrice Munyenyezi. Reva Adler, Cyanne Loyle, and Judith Globerman interviewed ten women perpetrators incarcerated in Rwanda in order to determine the reasons for their participation. Focusing on attitudes and beliefs, they peeled back layers of influence and the "subtle and complicated interplay between accepting their role as homemaker and compliant spouse and, at the same time, forming and acting on political beliefs in making decisions to participate in genocidal activities." ${ }^{35}$ These studies speak to the limited agency exercised by women in Rwanda and further inform expanded research on gendered mobilization, militarization, and perpetration.

But if the role of women during violent upheaval, including the Rwandan case, has gained recognition, the motivations of their agency remain unexplored. Gender and the Genocide in Rwanda thus asks questions about the conditions under which women perpetrate violence, thereby aligning closely with work by Ted Robert Gurr and Barbara Harff, who explore factors that precipitate the perpetration of mass violence, including genocide. ${ }^{36}$

Gender and the Genocide in Rwanda employs a comparative historical approach as a complement to feminist theory. This interdisciplinary approach builds upon the history of gender norms and mobilization during significant junctures in Rwandan history and serves two inter-connected purposes: to deepen the level of analysis and, with that deepened analysis, to develop effective preventive measures. ${ }^{37}$ As Holocaust historian Christopher Browning has shown in his landmark study Ordinary Men: Reserve Police Battalion 101 and the Final Solution in Poland, the (men) perpetrators he studied became killers in a particular historical and social context. ${ }^{38}$ So, too, were Rwanda's citizens shaped by significant historical events that affected women rescuers and perpetrators alike. Yehuda Bauer notes that a comparative analysis is necessary as,

we cannot treat all kinds of mass murder in the same way, because they have to be dealt with differently in order at least to diminish them. You don't treat typhoid and cholera with the same medicine, though they are both deadly illnesses.... The analysis is necessary, then, not to satisfy some abstract intellectual urge, but for very practical reasons: you have to understand what you are dealing with in order to be able to deal with it intelligently. ${ }^{39}$

Careful and nuanced analysis of the diverging roles women rescuers and perpetrators played during the genocide in Rwanda uncovers the intersection of gender and agency with underlying trends, causality, and outcomes that resulted in genocide in 1994 Rwanda. With such an understanding, proactive and effective genocide-prevention strategies may be developed that incorporate women's agency and role in perpetuating or preventing genocide. ${ }^{40}$

If feminist theory helps us to understand one set of issues and a comparative historical approach illuminates violent periods during Rwanda's history, 
sociology and constructivism allow us to plumb the role of identity formation and re-formation during periods of upheaval and uncertainty. This is of particular relevance in the Rwandan case. As sociologist Emile Durkheim posited, "there can be no society that does not feel the need of upholding and reaffirming at regular intervals the collective sentiments and collective ideas that make its unity and personality." ${ }^{\prime 11}$ These processes of formation and affirmation are often accelerated during instances of societal fragmentation and include "gendered identities of state. ${ }^{\prime 42}$ The dynamic nature and influence of identity provides a key analytic lens for the pre-genocide mobilization and militarization of women, diverging manifestations of agency during the genocide, and post-genocide realities. The process of identity formation and the policing of intra- and inter-group boundaries are some of the causal roots of women's agency. These "imagined communities" based upon constructed identity boundaries give a sense of membership and belonging that often result in "us vs. them" mentalities. Such exclusionary frames can then be manipulated to mobilize and sensitize populations to participate in violence ${ }^{43}$ Gendered notions of identity and gender-based identity formation inform the ways people act in the public sphere and in the private sphere. ${ }^{44}$ This is relevant to gender-based grouping and gender-based violence in instances of mass atrocities. Identity does not exist in a vacuum: it is subject to and interacts with other factors that may manipulate the concept of self to trigger acts of altruism or violence.

Grounded in feminist theory, Gender and the Genocide in Rwanda trains an analytical lens on women and incorporates comparative genocide studies and comparative historical analysis, which combine to expose commonalities and differences in experiences between two groups of women during periods of upheaval and violence in Rwanda. Combined with sociology and constructivism, Gender and the Genocide in Rwanda addresses the dynamic nature of individual identity and women's collective identity. This interdisciplinary combination to analyze women's agency during the genocide in Rwanda offers a fresh approach.

\section{Methodology}

I applied a modified grounded theory in the development of my research design, data collection, and comparative analysis. While grounded theory is inductive, pulling findings from analysis of data and developing resulting theories, my modified approach applied a deductive component based upon prior field experience and knowledge. ${ }^{45}$ Gender and the Genocide in Rwanda is founded upon primary source materials and based on the analysis of semi-structured interviews with 77 respondents, ${ }^{46} 15$ oral testimonies provided by the Association des Veuves du Genocide (AVEGA Agahozo, the Association of the Widows of Rwanda), ten oral histories provided by the Kigali Genocide Memorial and the Genocide Archive of Rwanda, archive materials, and six meetings with individuals living in Rwanda who could speak about women rescuers and perpetrators during the genocide in Rwanda. The selection criteria for research 


\section{Finding the Right Flashlight}

respondents was limited to: men or women who were community and government stakeholders; women who were rescuers or perpetrators during the genocide; men or women survivors of the genocide; and women involved in non-governmental organizations who participate(d) in the post-conflict reconstruction and rehabilitation of Rwanda. As the emphasis of this study is on the participation and impact of women, just 16 interviews were conducted with men respondents. Of the 77 respondents, 75 are Rwandan, and they represent a broad spectrum of Rwandan society with respect to socioeconomic status, access to power and influence, formal education, and age. Respondents were not asked to identify their ethnic background but many voluntarily identified themselves as Hutu, Tutsi, Twa, or a combination of these ethnicities. In-country research was conducted over the course of five trips in 2010, 2011, 2012, and two in 2014. ${ }^{47}$

This research sample includes interviews with 16 women rescuers, five women rescuers interviewed by staff at the Kigali Genocide Memorial and Genocide Archive of Rwanda, and 26 women incarcerated for genocide crimes. The disparity in the number of women rescuers and women perpetrators is a result of the institution of the Gacaca courts, which created a formalized mechanism for identifying women perpetrators through the country and verifying their testimonies. No similarly streamlined nationwide mechanism for identifying women (and men) who rescued during the genocide has been developed. Some efforts to identify rescuers have been mounted, including one by IBUKA (meaning "remember" in Kinyarwanda), an umbrella organization that supports survivors throughout Rwanda, but it covers just 14 percent of the sectors. ${ }^{48}$ Other organizations have worked to identify the "righteous" in Rwanda but have not managed to make significant headway. It was thus much more difficult to identify women rescuers and verify their testimonies.

I collected and analyzed testimonies and oral histories provided by survivors, witnesses, rescuers, and perpetrators who identify women actors during the violence, and triangulated their accounts with archival documents and legal testimonies. In an effort to meet women who can speak about the periods of violence they experienced and the role that they or other women played, I interviewed incarcerated women serving time in Works for General Interest (TIG) programs; survivors of the genocide; and individuals who rescued others during the genocide. Interviews took place throughout Rwanda. ${ }^{49}$

Twenty-one of the 26 women perpetrators stated that they had never been interviewed about their participation in the genocide before. Of the 26, 25 were serving time under the second category of offenders, a broad category that includes: murder; torture; dehumanization of a corpse; accomplice to murder; and violence without intent to murder. ${ }^{50}$ All 26 women identified themselves as Christian, affiliated with the Catholic, Protestant, Seventh-day Adventist, or Pentecost churches. The overall level of education among these second-category offenders was low, ranging from no formal education to partial completion of primary school. Just one woman had completed primary school and obtained a certificate in sewing from a trade school. This woman was the only one of the second-category offenders who did not identify herself as a farmer prior to 
incarceration; 25 of the women came from low-income backgrounds, relying on subsistence farming or a trade to survive, and none had earned a secondary school certificate. The women constituted a geographically diverse sample, coming from cities, towns, and small villages throughout the country. They varied in age, level of family involvement in the genocide, and political participation.

Similar to the women perpetrators, all of the 16 women rescuers interviewed identified themselves as Christian, affiliated with the Catholic, Protestant, or Seventh-day Adventist churches. The level of education among the majority of women rescuers and their geographic spread throughout the country - in cities, towns, and small villages - mirrored that of the perpetrators; however, one woman rescuer had obtained a teaching certificate, and another had obtained a $\mathrm{PhD}$ and lived in the United States before returning to Rwanda during the genocide. With the exception of a teacher and a professor, the women were farmers from low-income backgrounds. The five women rescuer testimonies provided by the Kigali Genocide Memorial Center mirrored these demographics with an exception: one rescuer was a Muslim.

There are limitations to the use of oral histories. I have found that participants may be influenced by a host of factors including, most significantly, my gender, race, and nationality. That I am a woman seemed to calm participants, who expressed enthusiasm regarding my gender. In this respect, the influence of my gender weighed in favor of my research. The same can be said about my Jewish identity when I interviewed survivors, who often referred to me as a fellow "survivor." Also, my nationality, both American and Israeli, was well received, but it is difficult to counteract the influence that perceptions of American hegemony, wealth, and power had on the interview. My nationality was problematic almost without exception, both with participants who have been interviewed dozens of times and with participants who were providing their narrative to a researcher for the first time.

Combined, these factors and their influence created a power imbalance that was difficult to counteract. I attempted to neutralize their influence with several deliberate measures. I offered participants an extensive personal introduction in which I explained my work and research experience in the region. After my introduction, I gave participants the opportunity to ask me any questions that came to mind. This unscripted discussion gave the participants a chance to ask me personal and professional questions and determine if they felt comfortable proceeding with the interview. When possible, I used culturally appropriate rituals of greeting, behavior, and language to indicate a familiarity with Rwandan culture and assure the participant that I was not a newcomer. Lastly, I relied upon my rapport with my translator, who was trained in my research and would spend the first few minutes speaking freely with the participant in Kinyarwanda about our work. This allowed the participant to get settled and ask as many questions as necessary of my translator, a fellow Rwandan, in order to feel comfortable.

The semi-structured interview style I employed produced an inter-personal exchange between the interview participant, my translator, and me. Equally 


\section{Finding the Right Flashlight}

significant, the non-uniformity of their answers, encouraged by open-ended questions and a dynamic question-and-answer format, showed variation in intention, thought, and self-awareness, and allowed me to look at the individual beyond rigid grouping categories (such as gender, class, race, etc.). As oral historian Alessandro Portelli has observed, "The fact that a culture is made of individuals different from one another is one of the important things that social sciences sometimes forget, and of which oral history reminds us." ${ }^{51}$ The interpersonal relationship and semi-structured questions thus allowed for a more indepth look at the individual within the social group.

A note about language. Most of my interviews with perpetrators were conducted in Kinyarwanda and I employed a translator. In order to maintain consistency, accuracy, and a high ethical standard, I employed the same translator since 2010, whom I hired upon referral from another organization working with the survivor and rescuer populations in Rwanda. I chose a woman translator upon the recommendation of Rwandan colleagues who stressed that women would be inclined to speak more freely with other women. I trained my translator extensively in specific interviewing techniques, the anonymity of the participants, and the content of my research. She was present for every interview with a woman with the exception of Valerie Bemeriki. For that interview, I trained and employed another translator who also worked as my Kinyarwanda instructor. When interviewing men who were part of the Rwandan military structure, it was recommended that I employ a man as translator in order to respect certain cultural sensitivities (read: performed masculinities) that still exist in the Rwandan military structure. Eager to avoid offending Rwandan culture, I trained and employed a man translator who provided assistance with one interview with a high-ranking military commander. I struggled with this decision. While I wished to respect cultural relativism and accepted certain elements of patriarchy in Rwanda culture in order to conduct quality research, I did not wish to perpetuate a view that militarized masculinity is "normal" and that gender-exclusive interviewing techniques are optimal. In addition, I worked to ensure consistent and accurate Kinyarwanda-to-English translation. I selected a random sample of testimonies from my interviews and the Kigali Genocide Memorial archives, and had them translated by a third translator trained in oral testimonies. I then compared transcripts to verify accuracy, consistency, and quality.

Despite these efforts, certain challenges were unavoidable. Testimonies gathered by the Kigali Genocide Memorial often took the form of lengthy ethnographic interviews and included valuable information but often did not address the gendered experiences of women in a patriarchal state. And testimonies provided to me by AVEGA Agahozo included many details but were already translated into English so I was unable to verify the quality of the translation. In addition, some perpetrator participants I interviewed are reluctant to admit the full scope of their actions during the genocide. This could be due to a lapse in memory due to the passage of time (an issue that sometimes occurs with survivor, witness, and rescuer testimonies as well), my identity or the perceived ethnicity of my translator, or an effort on the part of the participant to misrepresent 
herself. I checked a random sample of their testimonies against Gacaca courts' transcribed records and signed confessions, although this process is not standardized due to the availability of legal records. ${ }^{52}$ Whenever possible, I endeavored to triangulate testimonies with archive sources, corroborating testimony, and transcribed documents. In Rwanda, this includes the former International Criminal Tribunal for Rwanda's Information and Documentation Center, the Kigali Genocide Memorial, the Genocide Archive of Rwanda, and the National Museum.

The collection of oral histories as well as archive materials was undertaken with the permission of the individual or organization as well as the government, which now has a standardized review process in place for research with human subjects similar to the Institutional Review Board in the United States. I met potential participants through a number of routes, including Rwandan organizations whose primary beneficiaries and personnel are women and whose mandate is relevant to my research questions. Through organizations like IBUKA, AVEGA Agahozo, Association des Etudiants et Éleves Rescapés Du Genocide (AERG), and the Kigali Genocide Memorial, I met individual women and men to interview about the violence they experienced and the role that they or other women played. I also sought out organizations that operated during the genocide. Government bodies are key sources of information. I was in contact with the National Courts as well as the Gacaca courts, prison officials at the now consolidated National Prison Service (NPS), and various government bodies in order to interview government stakeholders, women rescuers and perpetrators, review testimonies, and obtain access to government resources. Women perpetrators were randomly sampled from a list of TIG camps that house women incarcerated for genocide-related crimes, provided by NPS. I reached out to universities such as the Center for Conflict Management and the Law School at the National University of Rwanda, now merged into the University of Rwanda. Government and community stakeholder respondents were identified through extensive profile research and through the snowball method of sampling. They were contacted by telephone or e-mail with a letter of introduction and request for an interview. Theses interviews often took the form of ethnographic interviews, including directly lived experience, the experiences of others, and cultural norms in addition to organizational details. In-person and recurring visits served as the foundation for building trust and cultivating long-term relationships with the individuals and organizations that were key to my research.

Throughout my research, I was cognizant of my role as a participant observer. Not only did I conduct my research in Rwanda, gathering information, observing Rwandan society, and collecting interviews, I was a participant in these exchanges and events and was so influenced.

\section{Definitions}

Definitions were developed using the aforementioned modified grounded theory. In Kinyarwanda, the language spoken in Rwanda, there is no word for 
"genocide." Following the 1994 genocide, Rwanda borrowed the western word "genocide," regularly translating it into its French (misspelled) variation jenocide. But in the rural regions of Rwanda where English and French are not as prevalent, Kinyarwanda speakers often described the genocide as an instance of intambara or war, a term many survivors feel is deliberately employed to diminish or deny the horrors of the genocide. At the same time, Kinyarwanda terms have developed over time to describe the people who were affected by the genocide. Victims are referred to as inzirakarengane or innocent people; survivors are abacitse kw'icumu or those who escaped the spear ("spear" here refers to an assortment of calamities); perpetrators are abakoze jenocide or the genocide workers/doers, or more generally as abakoze ibyaha or the sin workers/ doers; and rescuers are abarokoye abatutsi muri jenocide or those who hid Tutsis during the genocide. Though Kinyarwanda has a word for rescuers, abatabazi, this term has a complicated history as it was part of the official title of the genocidal government, Guverinoma y'Abatabazi or government of rescuers, which took over in the days after the assassination of president Juvénal Habyarimana in 1994 and perpetrated the genocide afterwards.

"Agency" refers to conscious acts of compliance with or resistance against the dominant, violent social structure, undertaken at personal risk and within a gendered context during the genocide in Rwanda. This is premised upon the underlying belief that all women made a choice. Women's agency is thus defined as the deliberate choice to take action, often at great personal risk to self and family. Perpetrators took personal risk when they participated in genocidal crimes, and those women who rescued took perhaps even greater risks when they acted to protect targeted victims.

Bystanders, by contrast, made the conscious and active choice not to take action. To be a bystander during the genocide in Rwanda was to exercise a form of agency; the decision not to act was a course of action in its own right. Both men and women stood by due to fear. And many were paralyzed by it and tried to remain invisible throughout the genocide. For women in particular, the choice to remain a bystander and feign neutrality was socially acceptable and encouraged, as it benefitted the perpetrators, not the victims. In addition, contrary to the masculinized characterization of women victims as passive, women victims exercised agency in instances of tremendously limited options.

The definitions for women rescuers and perpetrators were developed over time, informed by interviews with survivors, rescuers, perpetrators, and community and government stakeholders, and with the knowledge gained from archival documents and legal parameters. Women rescuers participated in a broad range of acts that constitute rescue, including harboring, aiding, protecting, and otherwise preventing the victimization of a targeted person or group. I cast a similarly broad net when defining women perpetrators in Rwanda, which include women who participated in acts of direct and indirect violence. Direct person-to-person violence includes murder, assault, theft, and exposing those in hiding, while indirect violence includes planning, organizing, and inciting violence perpetrated by others. 


\section{Notes}

1 J. Ann Tickner, "Feminism Meets International Relations: Some Methodological Issues," in True Feminist Methodologies for International Relations, eds. with Issues." in True Feminist Methodologies for International Relations, edited by Brooke Ackerly, Maria Stern, and Jacqui True (New York: Cambridge University Press, 2006): 25.

2 Cynthia Enloe, Globalization and Militarism: Feminists Make the Link (New York: Rowman \& Littlefield Publishers, 2007): 53.

3 Cynthia Cockburn, "The Continuum of Violence," in Sites of Violence, eds. with Violence." in Sites of Violence, edited by Wenona Giles and Jennifer Hyndman (Los Angeles: University of California Press, 2004): 29.

4 J. Ann Tickner, Gendering World Politics (New York: Columbia University Press, 2001): 15.

5 Erin Baines, "Gender, Responsibility, and the Grey Zone: Considerations for Transitional Justice," Journal of Human Rights 10, no. 4 (2011): 482.

6 Tickner, 2001, 22.

7 Barbara Laslett, Mary Jo Maynes, and Jennifer Pierce, Telling Stories (Ithaca: Cornell University Press, 2008): 15.

8 Cynthia Enloe, "Womenandchildren: Making Feminist Sense of the Persian Gulf War," Village Voice, 25 September 1990.

9 David Moshman, "Conceptual Constraints on Thinking about Genocide," Journal of Genocide Research 3, no. 3 (2001): 431.

10 Reva. N. Adler, Cyanne E. Loyle, and Judith Globerman, "A Calamity in the Neighborhood: Women's Participation in the Rwandan Genocide," Genocide Studies and Prevention 2, no. 3 (2007): 211.

11 Tickner, 2001, 59.

12 Kathleen M. Blee, Women of the Klan: Racism and Gender in the 1920s (Los Angeles: University of California Press, 1991).

13 Claudia Koonz, Mothers in the Fatherland: Women, the Family, and Nazi Politics (New York: St. Martin's Press, 1987).

14 Wendy Lower, Hitler's Furies: German Women in the Nazi Killing Fields (New York: Houghton Mifflin Harcourt, 2013).

15 There is literature I strongly recommend as part of the larger conversation taking place. While not included in this publication, these resources are of great value and will be incorporated into the notes. For example, see: Carrie Hamilton, "The Gender Politics of Political Violence: Women Armed Activists in ETA," Feminist Review 86 (2007): 132-48; Ana Christina Ibanez, "El Salvador: War and Untold Stories Women Guerillas" in Victims, Perpetrators, or Actors? edited by Caroline N. O. Moser and Fiona Clark (New York: Zed Books, 2001): 12-29; Keren Kampwirth, Women \& Guerrilla Movements: Nicaragua, El Salvador, Chiapas, Cuba (University Park: University of Pennsylvania Press, 2002); Megan MacKenzie, "Securitization and De-Securitization: Female Soldiers and the Reconstruction of Women in PostConflict Sierra Leone." In Gender and International Security, edited by Laura Sjoberg (New York: Routledge, 2010): 24-37; Sandra McEvoy's doctoral dissertation on women in the Loyalist paramilitary in Ireland; Dyan Mazurana and Susan McKay, "Where are the Girls? Girls in Fighting Forces in Northern Uganda, Sierra Leone, and Mozambique: Their Lives During and After War," Rights and Democracy (2004); Jan J. Pettman, Worlding Women (New York: Routledge, 1996); and Karen Turner, Even the Women Must Fight: Memories of War from North Vietnam (New York: John Wiley \& Sons, 1998).

16 Annica Kronsell, "Method for Studying Silences: Gender Analysis in Institutions of Hegemonic Masculinity." In True Feminist Methodologies for International Relations, 


\section{Finding the Right Flashlight}

edited by Brooke Ackerly, Maria Stern, and Jacqui True (New York: Cambridge University Press, 2006): 108-28.

17 Brooke Ackerly, Maria Stern, and Jacqui True, "Feminist Methodologies for International Relations." In True Feminist Methodologies for International Relations, edited by Brooke Ackerly, Maria Stern, and Jacqui True (New York: Cambridge University Press, 2006): 1-16.

18 Laura Sjoberg and Carol Gentry, Mothers, Monsters, Whores: Women's Violence in Global Politics (London: Zed Books, 2007): 12-13.

19 Andrea Dworkin, Woman Hating: A Radical Look at Sexuality (New York: Plume, 1974); Catherine A. MacKinnon, Are Women Human? And Other International Dialogues (Cambridge: The Belknap Press of Harvard University Press, 2006).

20 See Chris Crais and Pamela Scully, Sara Baartman and the Hottentot Venus: A Ghost Story and a Biography (Princeton: Princeton University Press, 2009).

21 Jan J. Pettman, Worlding Women (New York: Routledge, 1996): 32.

22 Ervin Staub, The Roots of Evil: The Origins of Genocide and Other Group Violence (Cambridge: Cambridge University Press, 1989); James Waller, Becoming Evil: How Ordinary People Commit Genocide and Mass Killing, 2nd ed. (New York: Oxford University Press, 2011); Victoria Barnett, Bystanders: Conscience and Complicity during the Holocaust (Connecticut: Greenwood Press, 1999).

23 Ervin Staub, Overcoming Evil: Genocide, Violent Conflict, and Terrorism (New York: Oxford University Press, 2011). See also: Samuel P. Oliner and Pearl M. Oliner, The Altruistic Personality: Rescuers of Jews in Nazi Europe (New York: The Free Press, 1988); and multiple publications by Nechama Tec, including Resilience and Courage: Women, Men, and the Holocaust (New Haven: Yale University Press, 2003), Defiance: The Bielski Partisans (New York: Oxford University Press, 1993), In the Lion's Den: The Life of Oswald Rufeisen (New York: Oxford University Press, 1990), and When Light Pierced the Darkness: Christian Rescue of Jews in Nazi-Occupied Poland (New Haven: Yale University Press, 2003).

24 Jean Hatzfeld, Machete Season: The Killers in Rwanda Speak (New York: Farrar, Straus and Giroux, 2005); and Scott Straus, The Order of Genocide: Race, Power, and War in Rwanda (Ithaca, NY: Cornell University Press, 2006).

25 Christine Saidi, Women's Authority and Society in Early East-Central Africa. (Rochester: University of Rochester Press, 2010): 8.

26 Ibid.

27 Mahmood Mamdani, When Victims Become Killers: Colonialism, Nativism, and the Rwandan Genocide (Princeton: Princeton University Press, 2001): 5.

28 René Degni-Ségui, "Question of the Violation of Human Rights and Fundamental Freedoms in any Part of the World, with Particular Reference to Colonial and Other Dependent Countries and Territories: Report on the Situation of Human Rights in Rwanda," United Nations Economic and Social Council, 29 January 1996: 6.

29 Chimamanda Ngozi Adichie, "The Danger of a Single Story,” TED Talk, July 2009.

30 Jonathan D. Wadley, "Gendering the State: Performativity and Protection in International Security." In Gender and International Security: Feminist Perspectives, edited by Laura Sjoberg (New York: Routledge, 2010): 53.

31 Dalia Ofer and Lenore J. Weitzman (eds.), Women in the Holocaust (Binghamton: Vail Ballou Press, 1999): 1.

32 Ibid.: 13.

33 African Rights, Rwanda: Not So Innocent - When Women Become Killers (London: African Rights, 1995): 4.

34 Lisa Sharlach, "Gender and Genocide in Rwanda: Women as Agents and Objects of Genocide," Journal of Genocide Research 1, no. 3 (1999): 387-99: 392.

35 Adler et al.: 222.

36 See Barbara Harff, "No Lessons Learned from the Holocaust? Assessing Risks of Genocide and Political Mass Murder since 1955," American Political Science Review 
97, no. 1 (2003): 57-73; Ted Robert Gurr and Barbara Harff, Ethnic Conflict in World Politics (Boulder: Westview Press, 1994); Ted Robert Gurr and Barbara Harff, "Systematic Early Warning of Humanitarian Emergencies," Journal of Peace Research 35 no. 5 (1998): 551-79; and Ted Robert Gurr's foundational book Why Men Rebel (Princeton: Princeton University Press, 1970).

37 For sources that cover the history of the Rwandan kingdom, colony, and state, see: Jean-Pierre Chrétien, The Great Lakes of Africa: Two Thousand Years of History (New York: Zone Books, 2003); Alison Des Forges and David S. Newbury, Defeat is the Only Bad News: Rwanda under Musinga, 1896-1931 (Madison: The University of Wisconsin Press, 2011); René Lemarchand, Rwanda and Burundi (New York: Praeger Publishers, 1970); Mamdani's previously mentioned work When Victims Become Killers: Colonialism, Nativism, and the Genocide in Rwanda; Jacques Maquet, The Premise of Inequality in Ruanda: A Study of Political Relations in a Central African Kingdom (London: Oxford University Press, 1961); Catherine Newbury, The Cohesion of Oppression: Clientship and Ethnicity in Rwanda, 1860-1960 (New York: Columbia University Press, 1988) and "Ethnicity and the Politics of History in Rwanda," Africa Today 45, no. 1 (1998): 7-24; and Jan Vansina, Antecedents to Modern Rwanda: The Nyiginya Kingdom (Madison: University of Wisconsin Press, 2004).

38 Christopher Browning, Ordinary Men: Reserve Police Battalion 101 and the Final Solution in Poland (New York: HarperCollins Publishers, 1993). The significance of context and the situation has been studied at length by social psychologists including Stanley Milgram (see his "Obedience to Authority" experiment) and Phillip Zimbardo (see his "Stanford Prison" experiment).

39 Yehuda Bauer, "Comparison of Genocide." In Studies in Comparative Genocide, edited by Levon Chorbajian and George Shirinian, 31-43 (New York: St. Martin's Press, 1999): 32.

40 Gender and the Genocide in Rwanda is further informed by Hannah Arendt's The Origins of Totalitarianism (Cleveland: World Publishing, 1948) and scholarly debate about the role of colonial imperialism and genocide. For works on colonialism and genocide, see Christopher Lee, "Locating Hannah Arendt within Postcolonial Thought: A Prospectus," College Literature 38, no. 1 (2011): 95-114; Dirk Moses, "Hannah Arendt, Imperialisms, and the Holocaust," in German Colonialism, Race, the Holocaust, and Postwar Germany, edited by Volker Langbehn and Mohammad Salama, 72-92 (New York: Columbia University Press, 2011); several works by Jürgen Zimmerer including "Annihilation in Africa: The 'Race War' in German Southwest Africa (1904-1908) and its Significance for a Global History of Genocide," GHI Bulletin 37 (2005): 51-7; "Colonial Genocide: The Herero and War (1904-1908) in German South West Africa and its Significance." In The Historiography of Genocide, edited by Dan Stone, 323-43 (London: Palgrave, 2008), and "Colonialism and the Holocaust: Towards an Archeology of genocide," Development Dialogue 50 (2008): 95-125; and Carroll P. Kakel, The American West and the Nazi East: A Comparative and Interpretive Perspective (New York: Palgrave Macmillan, 2011).

41 Emile Durkheim, The Elementary Forms of the Religious Life, translated by J. W. Swain (New York: The Free Press, 1954 [1912]): 427.

42 Tickner, 2001: 53.

43 See Benedict Anderson, Imagined Communities: Reflections on the Origin and Spread of Nationalism (New York: Verso, rev. ed., 1983) and Waller's previously mentioned book Becoming Evil: How Ordinary People Commit Genocide and Mass Killing.

44 For more on the significance of public and private spheres and respective individual and team performances, see Erving Goffman, The Presentation of Self in Everyday Life (New York: Anchor Books, 1959).

45 For example, Atlas.ti software was used for initial analysis of oral history data. Coding was done inductively (pulling codes directly from the text of the interviews) 
and deductively (based upon prior experience that allowed me to understand content in context).

46 See Appendices A and B for the English translation of the questionnaires. Nine interviews were conducted in July/August 2014 as part of research for "Women Spoilers and Peace Builders in Rwanda 1994-2014," submitted to the International Institute for Democracy and Electoral Assistance (International IDEA) in 2014.

47 This research was approved by the Institutional Review Board for Protection of Human Subjects at Clark University.

48 Jean-Marie Kayishema and François Masabo, "The Rwandan Righteous 'Indakemwa' Pilot Study," IBUKA, December 2010; interview Naphtal Ahishakiye, interview by Sara E. Brown, Kigali, Rwanda, 14 January 2014.

49 Interviews were conducted in a semi-structured style, using probing questions to ascertain in greater detail the experiences of the individual.

50 Rwanda Government, "Summary of the Report Presented at the Closing of Gacaca Courts" Activities," June 2012: 6. Further elaboration of "category two" offenses is provided in Chapter 5, "Perpetrators."

51 Alessandro Portelli, The Death of Luigi Trastulli and other Stories: Forms and Meaning in Oral History (New York: State University of New York Press, 1991): 130.

52 At present, Gacaca courts' transcribed proceedings are handwritten and stored in boxes and on shelves. They are not digitized, nor are all records centrally organized.

\section{References}

Ackerly, Brooke, Maria Stern, and Jacqui True. "Feminist Methodologies for International Relations." In True Feminist Methodologies for International Relations, edited by Brooke Ackerly, Maria Stern, and Jacqui True. New York: Cambridge University Press, 2006: 1-16.

Adichie, Chimamanda Ngozi. "The Danger of a Single Story.” TED Talk. July 2009.

Adler, Reva. N., Cyanne E. Loyle, and Judith Globerman. "A Calamity in the Neighborhood: Women's Participation in the Rwandan Genocide." Genocide Studies and Prevention 2, no. 3 (2007): 209-33.

African Rights. Rwanda: Not So Innocent - When Women Become Killers (London: African Rights, 1995).

Baines, Erin. "Gender, Responsibility, and the Grey Zone: Considerations for Transitional Justice." Journal of Human Rights 10, no. 4 (2011): 477-493.

Bauer, Yehuda. "Comparison of Genocide." In Studies in Comparative Genocide, edited by Levon Chorbajian and George Shirinian, 31-43 (New York: St. Martin's Press, 1999).

Blee, Kathleen M. Women of the Klan: Racism and Gender in the 1920s (Los Angeles: University of California Press, 1991).

Browning, Christopher. Ordinary Men: Reserve Police Battalion 101 and the Final Solution in Poland (New York: HarperCollins Publishers, 1993).

Cockburn, Cynthia. "The Continuum of Violence." In Sites of Violence, edited by Wenona Giles and Jennifer Hyndman, 24-44 (Los Angeles: University of California Press, 2004).

Degni-Ségui, René. "Question of the Violation of Human Rights and Fundamental Freedoms in any Part of the World, with Particular Reference to Colonial and Other Dependent Countries and Territories: Report on the Situation of Human Rights in Rwanda." United Nations Economic and Social Council. 29 January 1996. 
Durkheim, Emile. The Elementary Forms of the Religious Life. Translated by J. W. Swain (New York: The Free Press, 1954 [1912]).

Dworkin, Andrea. Woman Hating: A Radical Look at Sexuality (New York: Plume, 1974).

Enloe, Cynthia. Globalization and Militarism: Feminists Make the Link (New York: Rowman \& Littlefield Publishers, 2007).

Enloe, Cynthia. "Womenandchildren: Making Feminist Sense of the Persian Gulf War." Village Voice. 25 September 1990.

Hatzfeld, Jean. Machete Season: The Killers in Rwanda Speak (New York: Farrar, Straus and Giroux, 2005).

Interview Naphtal Ahishakiye. Interview by Sara E. Brown. Kigali, Rwanda, 14 January 2014.

Kayishema, Jean-Marie and François Masabo. "The Rwandan Righteous 'Indakemwa' Pilot Study." IBUKA. December 2010.

Koonz, Claudia. Mothers in the Fatherland: Women, the Family, and Nazi Politics (New York: St. Martin's Press, 1987).

Kronsell, Annica. "Method for Studying Silences: Gender Analysis in Institutions of Hegemonic Masculinity." In True Feminist Methodologies for International Relations, edited by Brooke Ackerly, Maria Stern, and Jacqui True, 108-28 (New York: Cambridge University Press, 2006).

Laslett, Barbara, Mary Jo Maynes, and Jennifer Pierce. Telling Stories (Ithaca: Cornell University Press, 2008).

Lower, Wendy. Hitler's Furies: German Women in the Nazi Killing Fields (New York: Houghton Mifflin Harcourt, 2013).

MacKinnon, Catherine A. Are Women Human? And Other International Dialogues (Cambridge: The Belknap Press of Harvard University Press, 2006).

Mamdani, Mahmood. When Victims Become Killers: Colonialism, Nativism, and the Rwandan Genocide (Princeton: Princeton University Press, 2001).

Moshman, David. "Conceptual Constraints on Thinking about Genocide." Journal of Genocide Research 3, no. 3 (2001): 431-50.

Ofer, Dalia, and Lenore J. Weitzman (editors). Women in the Holocaust (Binghamton: Vail Ballou Press, 1999).

Pettman, Jan J. Worlding Women (New York: Routledge, 1996).

Portelli, Alessandro. The Death of Luigi Trastulli and other Stories: Forms and Meaning in Oral History (New York: State University of New York Press, 1991).

Rwanda Government. "Summary of the Report Presented at the Closing of Gacaca Courts' Activities.” June 2012.

Saidi, Christine. Women's Authority and Society in Early East-Central Africa (Rochester: University of Rochester Press, 2010).

Sharlach, Lisa. "Gender and Genocide in Rwanda: Women as Agents and Objects of Genocide," Journal of Genocide Research 1, no. 3 (1999): 387-99.

Sjoberg, Laura, and Carol Gentry. Mothers, Monsters, Whores: Women's Violence in Global Politics (London: Zed Books, 2007).

Staub, Ervin. The Roots of Evil: The Origins of Genocide and Other Group Violence (Cambridge: Cambridge University Press, 1989).

Staub, Ervin. Overcoming Evil: Genocide, Violent Conflict, and Terrorism (New York: Oxford University Press, 2011).

Straus, Scott. The Order of Genocide: Race, Power, and War in Rwanda (Ithaca, NY: Cornell University Press, 2006). 


\section{Finding the Right Flashlight}

Tickner, J. Ann. Gendering World Politics (New York: Columbia University Press, 2001).

Tickner, J. Ann. "Feminism Meets International Relations: Some Methodological Issues." In True Feminist Methodologies for International Relations, edited by Brooke Ackerly, Maria Stern, and Jacqui True, 19-41 (New York: Cambridge University Press, 2006).

Wadley, Jonathan D. "Gendering the State: Performativity and Protection in International Security." In Gender and International Security: Feminist Perspectives, edited by Laura Sjoberg, 38-58 (New York: Routledge, 2010).

Waller, James. Becoming Evil: How Ordinary People Commit Genocide and Mass Killing. 2nd ed. (New York: Oxford University Press, 2011). 


\title{
2 History of Rwanda
}

\author{
"Inkomezi yacyaane ica imigozi." \\ To pull too hard breaks the bonds. ${ }^{1}$ \\ (Rwandan proverb)
}

The genocide in Rwanda was rooted in specific historical events within (and beyond) the borders of the county. With no neat beginning or end, the genocide of 1994 was marked by overlapping and parallel processes which enabled and facilitated the perpetration of mass murder. In this chapter we shall briefly examine key elements of Rwanda's pre-colonial, colonial, and independence periods, and the intersecting influence and impact of sex-based and ethnic relations in order to trace developments that directly and indirectly contributed to the 1994 genocide and the role of women.

Prior to colonial rule, an established Rwandan kingdom traded throughout the region. The kingdom contributed to a group identity based upon shared culture, language, and leadership. Colonial rule (1897-1962) and Christian evangelism ${ }^{2}$ radically changed the systems of power and influence throughout the kingdom. Historian Jean-Pierre Chrétien has warned against the "double trap" of liberal history, in which Rwanda's pre-colonial era would be inaccurately idealized, and radical history, in which Rwanda's history would begin with the arrival of white colonizers. $^{3}$ A liberal history would erroneously characterize Mwami (the Kinyarwandan term for "monarch") Rwabugiri's pre-colonial monarchical rule as an era of peace and stability, and overlook both his militaristic and aggressive expansion and the subsequent instability and violence that occurred upon his death. In contrast, a radical history would mark the beginning of Rwanda's history with the arrival of its first colonial administrator, Richard Kandt, in 1898. The following historical synopsis embraces neither narrative and follows an independent course.

Most historians agree that by the fifteenth century Rwanda was organized in small semi-autonomous states, but the founding of the Kingdom of Rwanda remains subject to debate. ${ }^{4}$ By the eighteenth century, a monarchical state had developed that historians can document with some degree of precision. ${ }^{5}$ The expansion and consolidation of the kingdom also resulted in the creation and 


\section{History of Rwanda}

recognition of three distinct ethnic categories: Hutu, Tutsi, and Twa. ${ }^{6}$ Rwanda's monarchy was Tutsi-led and the royal family was comprised almost exclusively of Tutsis. Still, at that time, ibiiru, or court rituals, were carried out by Hutus, and a number of Hutus served as chiefs and sub-chiefs. ${ }^{7}$ Thus it was during the pre-colonial period that the oft-cited identities of "Tutsi" and "Hutu" took shape as political and cultural terms. The terms, however, were initially associated with "patron" and "client" respectively. ${ }^{8}$ While early clientship relationships were exploitative, founded on the exchange of land or cattle for allegiance and thus reflecting a power disparity, they varied by region and often proved beneficial both to the Tutsi patron and Hutu client. ${ }^{9}$ Throughout this period, a degree of identity fluidity existed wherein a Hutu could acquire enough wealth and power to transform into a Tutsi or, alternatively, a Tutsi could become a Hutu if they lost their cattle and status.

Rwanda's pre-colonial period was marked by patriarchal rule, notwithstanding certain powers that were afforded select women. The Mwami's power and kingship was passed from father to son and excluded women from the top tier of authority. Yet the kingship was determined according to the clan of the son's mother. As a result, according to historian Jan Vansina, the umugabekasi, or "Queen Mother" held clout "independent of that of the king and in principle equal to his." 10 Additionally, many Queen Mothers enjoyed significant influence over the Mwami that mimicked, in heightened form, the mother-son relationship common at that time in Rwandan culture. This maternal influence was simultaneously accepted and resisted, as described by historian and activist Alison Des Forges.

In Tutsi families the influence of the mother over her son often persisted even after he was thrust into the largely masculine world.... Continuing maternal influence was accepted as understandable but not desirable in a society where a son's interests were tied first and foremost to the lineage of his father. Such domination by a mother was known as ubukururamweko, "trailing a woman's sash after one's self."11

As the monarchy transitioned to a colonial state under Musinga (discussed in this chapter), this push-pull relationship between Queen Mother and Mwami proved disastrous for Rwandan independence.

Queen Mothers came from three matri-dynastic clans in Rwanda and played an essential role in the organization of the monarchy. ${ }^{12}$ Through turn-taking among the wives of the Mwami according to an agreed upon Esoteric Code, a power-sharing agreement among these influential clans was thus established and determined the succession of Rwandan sovereigns. ${ }^{13}$ However, this powersharing agreement was often subject to political maneuvering and deception, with the Queen Mothers playing a key role in royal succession politics. As we shall see, this was the case with Queen Mother Kanjogera.

Excluded in rhetoric but not in practice from these internal politics was the Mwami, who was elevated as infallible and occupied a demi-god-like status. 
One popular poem stated umwami si umuntu, or "the king is not a person."14 This exalted status did not extend to his many wives (polygamy was accepted practice at this time), although they exercised considerable power and accumulated their own wealth. The Mwami was referred to as the ubucurabwenge, the "Source of Wisdom," and was associated with certain symbols of power including the karinga, a royal drum that served as a physical and metaphorical symbol of the kingship. ${ }^{15}$ Even in instances of transgressions committed in the name of the Mwami, a Rwandan proverb stated that ntihica uMwami hica rubanda, or "it is not the Mwami who kills, it is his followers."16 Thus, the Mwami was not held accountable for various abuses of power that were carried out by his chiefs or his own Queen Mother, committed in his name.

The royal court was rife with intrigue as individuals and clans vied for influence and power. This culture of subversion and conspiracy had ripple effects that shaped the Mwami's leadership and contributed to the instability of the kingdom. In 1860, Mwami Rwabugiri ascended to the throne and ruled for 35 years. Under his sovereignty, the kingdom grew increasingly centralized, despite internal skirmishes (including the Mwami's decision to "purge his own lineage" and murder members of his family ${ }^{17}$ ) and continuous military campaigns that expanded its geographic size considerably. ${ }^{18}$ Interestingly, during Rwabugiri's reign, the royal drum was decorated with the testicles of defeated adversaries. ${ }^{19}$ After killing the mother of Rutarindwa, the son he had appointed his heir, Rwabugiri appointed his favorite wife, Kanjogera, as the boy's adoptive mother. This was problematic as Kanjogera was from a different clan than Rutarindwa. Kanjogera's clan often rivaled Rutarindwa's for power and challenged the Esoteric Code intended to prevent succession conflicts such as the one that followed..$^{20}$ Upon Rwabugiri's death, instability again rocked the royal court when Rutarindwa was challenged by his adoptive mother, Kanjogera, who allied with her clan and favored the assent of her son, Musinga. ${ }^{21}$ The most powerful person in Rwanda following the death of Rwabugiri, Kanjogera kept a tight rein over her own son and turned to clan purges, political assassinations, and ruthless violence to gain control of the kingdom. ${ }^{22}$ Legends of Kanjogera's sword continue to echo in modern Rwanda along with stories of her tyrannical power. But that period of violence proved the monarchy's undoing. By the 1890s, instability and violence had weakened the kingdom and created a power vacuum. Into that space entered Richard Kandt, a German explorer, and the White Fathers (Catholic priests who joined the foray of colonial influences in Rwanda) who capitalized upon the conflict and established themselves as colonial rulers. ${ }^{23}$

The continuing power struggle between Rwabugiri's heir Rutarindwa and Kanjogera was exacerbated by the newly arrived Germans and other contending European powers in the region. Flouting the Congolese-German agreement of 1884 between Belgium and Germany, the rogue Belgian officer Georges Sandrart invaded southwest Rwanda in 1896 and attempted to turn the chiefs in the region against the Rwandan ruler in favor of allegiance with the Belgiancontrolled Congo Free State. Enraged, Rutarindwa sent his army but the invaders' guns made short work of their bows and arrows. The Belgian and Congolese 
forces were turned back only after a German official intervened. ${ }^{24}$ This failed military campaign and rescue by foreigners proved the end for Rutarindwa's reign and, soon after, Musinga, carefully controlled by Kanjogera, assumed the throne.

Mwami Musinga embraced the German Protectorate so quickly that some historians question if he understood what accepting the German flag and aid actually meant. ${ }^{25}$ At the same time, the court was divided over the influence of German rule and the policy of accommodation instituted by Kanjogera's main adviser. These differences came to a violent head in 1905. But by then, the Germans were so powerful that they were able to intervene and stymie the usual wave of killings that unrolled after a power coup. ${ }^{26}$ They had successfully exploited the internal court rivalries to gain power.

Richard Kandt, the German Resident of Rwanda, was key to his country's success. Appointed to his post in 1908, he named Kigali the capital of the country. He deftly manipulated the Rwanda monarchy and the White Fathers to ensure German influence, emerging as one of three foci of power alongside the court and the White Fathers. ${ }^{27}$ An interplay of influence and politics between the three continued throughout colonization. ${ }^{28}$ The German role in protecting and influencing the White Fathers prompted Rwandans to view the priests as clients of the colonial power. The monarchy allowed them to settle in Rwanda but restricted them from instructing Tutsis; as a result, the White Fathers formed strong bonds with the Hutu population. ${ }^{29}$ Conflicts between the court and the White Fathers arose frequently and Kandt was brought in to adjudicate, thus gaining greater influence. In one instance, the court saw the priests' coercive conversion methods as a challenge to its authority and Kandt was asked to intervene and keep the peace between them. ${ }^{30}$ Tensions between the Mwami and the White Fathers eventually came to a head. After the Belgians formally replaced the Germans as the colonial authority in 1922, the White Fathers secured the downfall of Mwami Musinga and replaced him with the more pliable Mwami Rudahigwa, also known as Mwami Mutara. ${ }^{31}$

Before the Belgians took control of Rwanda, the Germans introduced into local society the pseudoscience of race and Arthur de Gobineau's theories of "culture-coded racism." ${ }^{32}$ During the nineteenth and early twentieth centuries, Europeans developed stereotypes about the alleged stupidity, simplicity, and inherent threat of "black" people. White European treatment of non-whites was characterized by "discrimination on the basis of allegedly 'racial' characteristics," and the assumption of white superiority. ${ }^{33}$ This race-based hierarchy promoted the subjugation and mistreatment of non-whites by their white oppressors, and Europeans' racist notions prompted them to equate the African continent with uncivilized societies and savagery that required civilizing and control.

Kingdoms such as Rwanda stood as a contradiction to European myths about non-white Africa. Rwanda was a highly developed society with established boundaries, a complex hierarchy, and elaborate rituals. To explain how that could be, Europeans seized upon and propagated the Hamitic theory. The Tutsi ruling class in Rwanda was identified as the lost sons of Ham. The biblical story 
of Noah's son, Ham, who was banished for laughing at his father's nakedness, served European imperialist objectives and supported the continuation of imperialist racism. The Hamitic myth was used to explain any sign of development throughout Africa. In Rwanda, according to political scientist Mahmood Mamdani, it resulted in the Tutsis becoming a racialized minority. The colonial application of the Hamitic myth signals the moment when the link between race and color was ruptured in Rwanda - from then on, "Tutsi" became a racial category, not just an ethnicity. ${ }^{34}$ As political scientist René Lemarchand has noted, "more than any other, it is the Hamitic myth that has had the most devastating impact on the texture of Hutu-Tutsi relations through much of the Great Lakes region, in effect providing ideological ammunition for the elimination of 'Hamites' by the 'Bantus,'" a common term for people indigenous to the region who spoke a variety of Bantu languages. ${ }^{35}$

The German colonialists deployed the Tutsi minority as a ruling class over the majority Hutu. They also took a direct approach, meddling in state affairs, particularly against the Mwami's consolidated power. Germany controlled Rwanda using this highly effective hybrid of indirect rule through the Tutsis, a divide and conquer policy, and asserting themselves through the royal court and its network of loyal chiefs and sub-chiefs. Education, too, was a tool to exacerbate the division between Hutu and Tutsi. After opening the first school in 1905, the White Fathers formalized an instruction policy in which Tutsis were taught in French, a European language, and Hutus were taught in Swahili, a local Bantu language ${ }^{36}$ It is no surprise that the multiple rebellions during this period targeted the monarchy rather than the colonialists and propagated an anti-Tutsi ideology.

Belgium took control of Rwanda after the defeat of Germany in World War I and collapsed its three colonies into one conglomerate, Congo Belge et RuandaUrundi in 1925. The Belgians institutionalized the German-constructed distinction between Hutu and Tutsi in Ruanda-Urundi and later turned myth into fact by developing colonial policies based upon it. Belgian rulers enacted colonial reform policies in the 1920s that reduced the number of Hutu chiefs, thereby upsetting the traditional balance of power between Hutu and Tutsi, and concentrated control in the hands of a select few Tutsi chiefs who often ruled with relative autonomy and near-absolute impunity. ${ }^{37}$ While these measures were intended to weaken Mwami Musinga in favor of the Tutsi chiefs and to work toward his downfall, it yielded numerous opportunities for abuse that further exacerbated Hutu-Tutsi divisions and the powerlessness of Rwandan women. ${ }^{38}$ This period of colonial rule further excluded women from the political sphere and codified their economic and political marginalization. As political scientist Timothy Longman put it, "Colonial rule effectively undermined even these limited avenues of power for women. Colonial laws and policies also undermined women's economic rights and opportunities." ${ }^{\prime 39}$ Gender and post-conflictreconstruction researcher and activist Elizabeth Powley notes the disenfranchisement of women by the colonial powers but also highlights the one exception to the rule. 
During the colonial period, Rwandan women did not have a voice in the public affairs or the administration for the colony. However, within the royal family, a Tutsi institution that the European authorities both tolerated and manipulated, the Queen Mother had a significant function. As protector of the heir to the throne and manager of the royal household, she played a "vital political role." 40

Kanjogera and the notoriety of her sword became both the dominant narrative of women during Rwanda's monarchical rule and a cautionary tale of what could occur should a woman come to power. Thus Powley notes that "the dominant image of female political leadership to emerge from the colonial period is that of treacherous and illegitimate authority." ${ }^{21}$ This stigma resonated with Rwandans and spurred women's continued relegation to the private sphere in the postcolonial period.

In addition, the colonialists developed ethnicity-based policies with respect to state administration, education, taxation, and the church. The Belgians squeezed Rwanda's Hutu population ruthlessly. They emphasized Hutu agriculture in order to maintain a steady stream of goods and sanctioned the use of force to impose mandatory unpaid Hutu labor, and to collect goods as well as taxes. Keeping with the indirect rule strategy, Tutsi chiefs were charged with collection from their Hutu subordinates. While some took happily to the task of violent enforcement, others were coerced: "You whip the Hutu or we will whip you. ${ }^{\$ 2}$

The national census of 1933-34 identified ethnicity on the basis of oral accounts, physical measurements, and cattle herd size. Once identity was legally codified, fluidity on a Hutu-Tutsi continuum ceased. ${ }^{43}$ Established at birth, ethnicity passed from father to child. Under the Belgians' fixed-identity system, women were not accorded a determining function in the identity of their children.

The role of German and Belgian colonizers in the construction and manipulation of ethnic identity was central to post-independence episodes of ethnic fracture and violence. ${ }^{44}$ The religious reign of the white priest was as effective as the executive reign of the white administrator. With 10,000 converts by 1914 and a decided bias toward the underserved Hutu majority, religious division exacerbated ethnic resentment among the Hutu majority. ${ }^{45}$

Christian proselytizing also brought with it a form of religious paternalism. Alison Des Forges identifies the Imandwa belief system as dominant in Rwanda prior to colonization and part of a broader pattern of belief systems in the Great Lakes region. Worship of Imana, an overarching force, and Imandwa, spirits believed to be more directly involved in day-to-day life, was widespread. ${ }^{46}$ Some worshipped Nyabingi, believed to be a female spirit, and gathered at training centers to serve her. ${ }^{47}$ Men and women alike served as spiritual intermediaries and mediums, leaders in the community who derived power and influence from their ability to intervene with the spirits on behalf of believers. The white Christian religious authorities marginalized these indigenous religious practices as 
heretical, thereby undermining the authority of women in religious practice. They then went a step further, denying women a decisive role in the church and subjugating them to the religious authority of an exclusively male clergy. ${ }^{48}$

The European powers sent people to central Africa, and events on the European continent rippled over, too. The two world wars proved major turning points for the colonizing states and their colonies. As we have seen, after Germany lost World War I, Belgium claimed Rwanda, and administrative changes and ethnic identity cards ensued. Later, the tables turned when Belgium, the colonial power in Congo, Rwanda, and Burundi, was occupied by the German Third Reich during World War II. Belgium emerged greatly weakened from World War II. In Congo, relations broke down between Brussels and Leopoldville as Belgium struggled to regain control of its colony after the war. In Kigali, tensions spiked and the situation grew increasingly unstable. ${ }^{49}$ Independence movements gained momentum and began to organize meaningful initiatives for self-rule.

On the heels of World War II, whites in South Africa and Rhodesia advocated for independent rule while, at the same time, non-white Africans pressed for a more meaningful role in their respective states. ${ }^{50}$ The newly drafted United Nations charter outlining its role and goals included Article 73, which proved central to the colonial independence movement. Article 73 on non-self-governing territories signaled a shift in global opinion regarding colonization and obligates members to "promote to the utmost ... the well-being of the inhabitants of these territories" and includes sections on "political, economic, social, and educational advancement," developing self-government in accordance with the aspirations of the people, and promoting development. ${ }^{51}$ The experience of World War II, combined with the creation of the United Nations, the development of the "Euroafrican state" concept of self-rule for African colonial states, and the heightened consciousness of colonial subjects in Africa, catalyzed the independence movements that swept through the continent, including the Great Lakes region, in the 1950s. Exploitative and oppressive to the end, the Belgians exited Rwanda in 1962 , leaving the country in disarray.

During the 1950s the Tutsi elite, followed quickly by the Hutu elite, too, began to call for Rwanda's independence. Rwanda followed a unique path to statehood. Arriving in Kigali in 1957, a United Nations decolonization mission received two documents. The first, drafted by the Mwami's court and titled Mise au Point, or "Clarification," called for a transfer of power from the Belgians back to the Mwami and his council. ${ }^{52}$ The second (and far more frequently cited of the two), was originally titled "Note on the Social Aspect of the Racial Native Problem in Rwanda." Drafted by nine Hutu male intellectuals, and eventually titled "The Manifesto of the Bahutu" (often referred to as "The Hutu Manifesto"), this statement denounced Tutsi domination, called for popular rule, and drew upon the Hamitic myth popularized by the colonial powers. Drafted with the assistance of the White Fathers, this document was not well received by the Tutsi elite, which denounced the Hutus. A series of ethnic-based atrocities committed by Hutus and Tutsis followed. ${ }^{53}$ 
The Hutu Manifesto marks the turning point for a decade that included political turmoil and growing ethnic tensions. In response to the Tutsi elite's mobilization for independence, the Belgians began to reorganize the governing system in Rwanda, introducing administration "councils" in 1952 and elections for a sub-chiefdom council in 1956. Tutsi leaders won 33 percent of the seats and did even better in elections for the chiefdom councils and the High Council of Rwanda. The High Council went on to draft (1957) a Statement of Views that advocated for a speedy transition to independence. Mwami Mutara, in power since Musinga's overthrow in 1931, sensed a propitious moment. Eager to gain power, he and his court introduced a series of reforms to ease royal restrictions on Hutus and win their favor. At the same time, the Catholic Church, which had become increasingly powerful throughout the colonial period and wielded considerable influence in Rwanda, publicly aligned with the Hutu majority in favor of a Christian democracy. ${ }^{54}$ The Church buttressed a developing Hutu elite, many of whom had been educated by Catholic missionaries, which began to call for majority-rule democracy in Rwanda, rejecting the monarchy and the colonial precedent of minority rule. Hutus and Tutsis did not unite in their call for independence; their post-independence visions were not congruent. And rather than engage both parties to develop a unified approach, the Belgians and the Catholic Church set one group against the other, exacerbating ethnic divisions and drafting documents that widened the gap between them.

While the elite class may have led the move for independence, they divided according to ethnic identity. Rather than forming a united front against Belgian colonial rule, the Hutus and Tutsis vied for power and mobilized the masses according to ethnicity in order to ensure their own success. Their demands were contradictory: the majority of Hutus wanted populist democratic rule, while the majority of Tutsis sought to maintain their power after independence. A united front was thus not possible and the focus of enmity turned inward, between Rwandans, rather than outward, against the colonial antagonist. While the original method of struggle was political and took the shape of manifestos and publications, it quickly devolved into ethnic violence between rival factions. Despite a shared language, history, culture, religion, and traditions, nationalism did not trump ethnic divisionism. In Rwanda, nationalism incorporated ethnic-related colonial myths and stereotypes. By the time the 1959 revolution had begun, these tensions exploded in acts of violence.

The 1959 revolution was triggered by a series of events. With the sudden death of Mwami Mutara, the enthronement of a successor without Belgian consultation occurred for the first time in decades and upset the traditional relationship between the colonizer and their elite proxy. The Mwami's death coincided with the formation of political parties grounded in ethnic identity and strengthening of the Hutu majority, further weakening Belgian's divide-and-conquer strategy. Vying along ethnic lines for votes in an early election led to a period of violence that destabilized Rwanda until 1963. The early independence period (1959-63) was marked by cyclical violence against Tutsis, ethnic extremism, and the first instances of large-scale perpetration and rescue in modern Rwandan 
history. Indeed, the meaning-making experience of rescue during the 1950s and '60s influenced several women who explained their acts of rescue ${ }^{55}$ decades later, during the 1994 genocide, as an extension of what they observed their family members having done during Rwanda's early independence period. These years also saw the end of Tutsi minority rule and a reorganization of power shared by a nexus of Hutu elites. If some scholars like Lemarchand assess this period positively, others, like Mamdani, argue that while the 1959 revolution catalyzed social and economic reforms, ending a period of Hutu exploitation and repression, it introduced a new level of political strife born of and simultaneously reinforcing the socially constructed identities of Hutu and Tutsi. ${ }^{56}$

Shaped by paternalism, justified by racism and religion, and rooted in economic exploitation, colonialism had split Hutus and Tutsis into separate consciousnesses and opposed ethnic groups. ${ }^{57}$ The Belgians could have worked toward a peaceful transition of power, but they fomented violence and ethnic stratification, playing off the two sides to what they perceived as their benefit. The role of the Catholic Church, by then the dominant religion in Rwanda, was equally important as it offered a religious validation for Hutu violence and sanctioned the formation of a government built upon ethnic divisionism. Focusing on the first four years of independence, Lemarchand stresses the role of the Catholic Church, arguing that the revolution would have "quickly fizzled had it not been for the sustained political, moral, and logistical assistance which the Catholic Church and the tutelle [Belgian colonial] authorities provided the insurgents." 58 Chrétien notes the role of seminary education in solidifying ethnic differences and fomenting an obsession with ethnicity among students who comprised the Hutu elite class. He concluded, "Up against the Tutsi elite, with its clerical wing and its support from customary leaders, a Hutu counter-elite - of teachers, priests, catechists, and medical and agronomic auxiliaries, whose influence could be relayed by artisans, traders, and truckers - crystallized." 59

Paternalism, too, played a determining role as a form of patriarchy evident in Rwanda's early independence development. The patriarchal construct of leaders post-independence was not new; it was simply a continuation of the paternalist theory and values of colonialism that had served as the colonial justification for occupation of the region. Drawing upon these experiences of paternalism in Rwanda, colonial and religious notions of patriarchy - as well as the pre-colonial model of the Mwami - the newly elected leader, Grégoire Kayibanda, presented himself as a father figure: the undisputed, infallible head of the country.

In the end, Belgian colonial influence did not result in a democratic Rwanda. The country was ruled by two dictators, Grégoire Kayibanda (1962-73) and Juvénal Habyarimana (1973-94), before the genocide. Following independence from Belgium on 1 July 1962, Kayibanda's newly formed Hutu government sought vengeance against the Tutsis in the first cycle of violence and instability in independent Rwanda. Some 20,000 Tutsis were murdered and over 300,000 were forced into exile in Uganda and abroad from 1963 to 1967. These violent measures were justified by the government as a necessary defense against the repeated incursions of Tutsi refugees along its northern border. The Belgian-initiated 


\section{History of Rwanda}

identity cards continued to be used by the new government and were a tool to discriminate against the remaining Tutsi population, denying them access to employment, education, and power. ${ }^{60}$

Habyarimana, a general in the Forces Armées Rwandaises (FAR), took power in a bloodless coup d'état following intra-ethnic conflict between Hutus from the north and Hutus from the south that culminated, by his design, in a wave of antiTutsi violence. The instability provided a window of opportunity for Habyarimana, who abandoned the façade of democracy and instituted a single-party state by 1975. ${ }^{61}$ According to Longman, this consolidation of power subsumed "all political and social activity under its umbrella, including women's organizations." ${ }^{\prime 62}$ Habyarimana quickly forged political and personal ties with France which, in an effort to supplant Rwanda's former colonial ruler, Belgium, and maintain influence in francophone Africa, assumed a patron-client relationship with Rwanda ${ }^{63}$ Habyarimana also enjoyed the support of the Catholic Church. It was during this period that a group of intimates, mostly from the north (like Habyarimana and his wife Agathe), formed the akazu or "little house," a network that enjoyed positions of power in business and government. Agathe operated in many ways as the gatekeeper for this consortium; to be admitted, most members relied upon familial connections to or relationship with Agathe rather than her husband. ${ }^{64}$ The legend of Kanjogera resonated among Rwandans, who nicknamed Agathe "Kanjogera" in light of the power she wielded. ${ }^{65}$ During Habyarimana's 21 -year reign, Rwanda's Tutsi minority suffered discrimination, marginalization, and occasional bouts of violence that escalated in the 1990s. However, while the dictatorships of Kayibanda and Habyarimana saw substantial violence, it was not on the scale of 1994 and with one notable difference: women were not targeted for death during their respective reigns. ${ }^{66}$ That came later, during the 1994 genocide.

While Agathe Kanziga (also known as Agathe Habyarimana) wielded considerable influence, an elaborate legal framework ensured that women remained economically and politically marginalized in Rwandan society. Men were legally recognized as the heads of Rwandan households according to the Family Code of 1992. In 1994, Rwandan women were prohibited by law from inheriting property or opening a bank account without the consent of their husband, and, representing just 5 percent of the executive branch of the Hutucontrolled Mouvement Républicain National pour la Démocratie et le Développement (MRNDD) government - previously known as the Mouvement Révolutionnaire National pour le Développement (MRND) - were not in a political position to advocate for change. ${ }^{67}$ Marginalization of women included the repression of the burgeoning women's rights movement that developed in Rwanda in the 1980s and early 1990s. These initiatives included an umbrella organization Pro Femme Twese Hamwe, with over a dozen subsidiary groups, and the Association for the Defense of Women and Children's Rights (HAGARUKA), and posed a threat not just to Rwanda's patriarchal society but to its nondemocratic political system as well. As a result, the groups were subsequently repressed or manipulated by Hutu extremists who sought to co-opt several organizations to further their extremist agenda. ${ }^{68}$ 
Then too, Rwandan women, regardless of ethnicity or class, were influenced by culturally prescribed and proscribed norms that limited their autonomy. Rwanda's public and political spheres were restricted primarily to men, while women were consigned to the home. Emphasizing the primacy of a woman's place within the four walls of her compound, a popular proverb summarizes their role in Rwandan society: umugore niwe 'mutima urugo ("the woman is the heart of the home"). Restricted to the domestic private sphere, women were often marginalized within their homes, too, unable to challenge their husband's decisions. Peace scholar Ezechial Sentama has observed that in pre-genocide Rwanda,

Whatever men could do, a woman should and must obey. And then there is a saying in Rwanda that there is no mistake for men. Even beating a woman, even wasting money, even doing whatever he wants, there is no mistake for a man. ${ }^{69}$

In a culture that demanded obedience and subordination to men, Rwanda's women were hard pressed for a space to exercise agency. These deeply entrenched patriarchal systems gave women little latitude for autonomous action.

Even so, under Habyarimana's reign, certain gender-specific actions against Tutsis were sanctioned. The African Rights report, Rwanda: Not So InnocentWhen Women Become Killers, notes that Habyarimana's regime marked "the beginning of their [women's] widespread participation in violence" through the formation of French-inspired Comités de Salut Public that tasked Hutu men and women with identifying, registering, and, in some instances, reporting "suspicious" Tutsi. These lists were used by intelligence officials to target and interrogate Tutsi men and women suspected of assisting exiled Rwandans. Occasionally, Hutu women university students led campaigns against Tutsi women students and drove out Tutsi professors. These early instances of discrimination paved the way for later acts of violence; at least a dozen women are documented by Africa Rights for their participation both in the comité actions against Tutsi women and girls as well as the 1994 genocide. $^{70}$

Still, during the early years of the Habyarimana regime, Tutsis did not experience widespread violence. But the Hutu-Tutsi divisions had been internalized within the Rwandan psyche and externalized to the international community through scholarship and media coverage. By 1989, Chrétien observed that the " 'ethnic' virus - with the scent of pseudo eternity that colonial reshaping, modern politics, and the international media had attributed to the Hutu-Tutsi antagonism - was more virulent than ever."71 After decades of exile, a band of Tutsi exiles formed a rebel group known as the Rwandan Patriotic Front (RPF) and invaded Rwanda from Uganda in October 1990. Among other demands, the rebels called for the right to return home and a role in Rwanda's government. Alarmed by their swift advance, President Habyarimana sought help from French military forces, longtime allies of the president, which drove back the RPF fighters. The resulting stalemate catalyzed uneasy negotiations that 


\section{History of Rwanda}

eventually led to a peace agreement known as the Arusha Accords. Signed in 1993, the Arusha Accords were widely unpopular among the Hutu elite in Rwanda, which resisted any challenge to its power. The contentious negotiations tarnished President Habyarimana's popularity and coincided with international pressure for Rwanda to transition to a multi-party democracy, further weakening the president's dictatorship. A number of political parties formed as early as summer 1991, including several extremist parties that championed Hutu nationalism and advocated for violence against Tutsis. The political parties frequently clashed, as skirmishes, mob violence, and assassinations spread. While some notable women played a role - including Agathe Uwilingiyimana, a moderate Hutu leader who rose to the position of Prime Minister before she was assassinated on the first day of the genocide - the political sphere was characterized by patriarchal dynamics. Rwanda's national army, the FAR, began to train young men under the pretense of defending neighborhoods and tracking down infiltrators; these same men would later comprise the core of the Interahamwe killing militias. ${ }^{72}$

On the evening of 6 April 1994, a private jet carrying President Habyarimana began its descent into Kigali. As the plane approached the airport, it was shot out of the sky by a ground-to-air missile and crashed into the presidential compound, killing all passengers on board, including a number of Rwandan officials, the president of Burundi, and Rwanda's President Habyarimana. Immediately, the FAR and Interahamwe militia groups sprang into action under the direction of several key elites, most of whom were members of the akazu, the inner circle linked to Agathe Kanziga. They set up road blocks, distributed lists of influential Rwandans marked for murder, and conducted home raids. Rwanda's Radio Télévision Libre des Mille Collines, the popular mouthpiece for Hutu extremists and a key component of the anti-Tutsi propaganda machine, quickly blamed Habyarimana's assassination on the RPF and Tutsi fifth columnists, and launched a heated campaign of genocide incitement. Thus, the assassination of President Habyarimana triggered a series of actions, some pre-arranged by members of a secret cabal. Journalist Philip Gourevitch notes that,

Although Habyarimana's assassins have never been positively identified, suspicion has focused on the extremists in his own entourage - notably the semiretired Colonel Théoneste Bagosora, an intimate of Madame Habyarimana, and a charter member of the $a k a z u$ and its death squads, who said in January of 1993 that he was preparing an apocalypse. ${ }^{73}$

Investigations conducted by Rwanda ("The Mutsinzi Report") and by the British and the French support these suspicions. By the morning of 7 April, the genocide was underway in Kigali and soon spread throughout the country.

Local leaders who accepted the genocidal ideology rallied their constituents to participate in the "work" of eradicating all Tutsis in their area, promising looted resources and land as their reward. Able-bodied Hutu boys and men who resisted participating were rarely ignored; they were often coerced into joining 
the Interahamwe, threatened if they refused, and occasionally murdered, especially if they were caught aiding Tutsis. Over the course of the next 100 days, and under the cover of war with the RPF, over 900,000 Tutsis and Hutu moderates - who were opposed to ethnic divisionism and rejected the extremists were systematically hunted, tortured, raped, and murdered as part of an orchestrated genocide. ${ }^{74}$ Viewing the genocide against the Tutsi population in Rwanda and subsequent attacks against their forces as nullifying the previously negotiated ceasefire, the RPF renewed its campaign against the FAR and militia forces. Despite the presence of United Nations peacekeeping forces stationed in Kigali, the genocide continued unabated and without international interference, and was stopped only by the RPF, which took control of the country. Rwandans then began a lengthy reconstruction and rehabilitation process that continues to this day.

\section{Notes}

1 Alison Des Forges and David S. Newbury, Defeat is the Only Bad News: Rwanda under Musinga, 1896-1931 (Madison: The University of Wisconsin Press, 2011): 157.

2 Evangelism accompanied colonial influence and often served to justify colonial supremacy over Africans.

3 Jean-Pierre Chrétien, The Great Lakes of Africa: Two Thousand Years of History (New York: Zone Books, 2003): 37.

4 According to Mahmood Mamdani's summary of the various estimations: J. K. Rennie traces the establishment of the monarchy to 1532, Alexis Kagame states 1312, JeanNépomucène Nkurikiyimfura asserts 1468, and Jan Vansina argues 1482. See Mahmood Mamdani, When Victims Become Killers: Colonialism, Nativism, and the Genocide in Rwanda (Princeton: Princeton University Press, 2001): 61, 293.

5 Chrétien: $158-9$.

6 Des Forges and Newbury: 4.

7 Mamdani: 63.

8 Chrétien: 190.

9 For more on patron-client relationships, see Catharine Newbury's chapter "Early Clientship" in The Cohesion of Oppression: Clientship and Ethnicity in Rwanda, 1860-1960 (New York: Columbia University Press, 1988).

10 Jan Vansina, Antecedents to Modern Rwanda: The Nyiginyi Kingdom (Madison: The University of Wisconsin Press, 2004): 85.

11 Des Forges and Newbury: 73.

12 Chrétien: 123.

13 Ibid.: 31.

14 Vansina: 141.

15 Des Forges and Newbury: 4.

16 Ibid.: 41.

17 Gérard Prunier, The Rwanda Crisis: History of a Genocide. (New York: Columbia University Press, 1995): 24.

18 Mamdani: 61.

19 Vansina: 159.

20 Prunier: 24; Newbury: 58.

21 Newbury: 58.

22 Des Forges and Newbury: 23, 72-4.

23 Ibid.: 26; Chrétien: 86. 


\section{History of Rwanda}

24 Des Forges and Newbury: 15-16.

25 Chrétien: 248.

26 Des Forges and Newbury: 42-4.

27 Chrétien: 247, 252-3.

28 Des Forges and Newbury: $34-5$.

29 Ibid.: $28-9$.

30 Ibid.: $63-4$.

31 Chrétien: 275.

32 Mamdani: 77.

33 Jan Nederveen Pieterse, White on Black: Images of Africa and Blacks in Western Popular Culture (New Haven: Yale University Press, 1992): 50.

34 Mamdani: 87.

35 René Lemarchand, The Dynamics of Violence in Central Africa (Philadelphia: University of Pennsylvania Press, 2009): 57; Chrétien: 45.

36 Mamdani: 89.

37 Mamdani: 88, 91.

38 René Lemarchand, Rwanda and Burundi (New York: Praeger, 1970): 119-20.

39 Timothy Longman, "Rwanda's Paradox: Gender Equality or Emerging Authoritarianism?" In Women in African Parliaments, edited by Gretchen Bauer and Hannah E. Britton, 210-33 (Boulder: Lynne Reinner, 2005): 211.

40 Elizabeth Powley, "Strengthening Governance: The Role of the Women in Rwanda's Transition," Women Waging Peace series, October 2003: 10.

41 Ibid.

42 Mamdani: 94, 97.

43 Ibid.: 91.

44 Des Forges and Newbury: 16.

45 Chrétien: 221.

46 Des Forges and Newbury: 14, 57.

47 Ibid.: 103.

48 Longman: 211.

49 Crawford Young, Politics in the Congo: Decolonization and Independence (Princeton: Princeton University Press, 1965): 23-4.

50 Ibid.: 46.

51 United Nations, "Charter of the United Nations, Chapter XI, Article 73," 26 June 1945.

52 Mamdani: 116.

53 Ibid.: 116; Chrétien: 301-2.

54 Chrétien: 302.

55 Discussed in further detail in Chapter 4, "Rescuers."

56 Mamdani: 104.

57 Ibid.: 23-4.

58 Lemarchand, 2009: 81.

59 Chrétien: 299-300.

60 Alison Des Forges, Leave None to Tell the Story: Genocide in Rwanda (New York: Human Rights Watch, 1999): 39-40.

61 Ibid.: 40-1.

62 Longman: 213.

63 For more information, see Linda Melvern, A People Betrayed: The Role of the West in Rwanda's Genocide (New York: St Martin's Press, 2000).

64 Des Forges: 44, 62.

65 Powley: 10.

66 For more on women targeted for violence during the 1994 genocide, see work by Christopher C. Taylor, including Sacrifice as Terror: The Rwandan Genocide of 1994 (New York: Berg Publishers, 1999). 
67 Lisa Sharlach, "Gender and Genocide in Rwanda: Women as Agents and Objects of Genocide," Journal of Genocide Research 1, no. 3 (1999), 387-99: 391.

68 Georgina Holmes, Women and War: Gender, Media, and the Representation of Genocide (New York: I. B. Taurus \& Co, 2014): 107-9.

69 Interview Ezechial Sentama, interview by Sara E. Brown, Kigali, Rwanda, 25 June 2011.

70 African Rights, Rwanda: Not So Innocent - When Women Become Killers (London: African Rights, 1995): 9-11.

71 Chrétien: 317.

72 Des Forges, 1999: 140.

73 Philip Gourevitch, We Wish to Inform you that Tomorrow we will be Killed with our Families. (New York: Farrar, Straus and Girous, 1998): 113.

74 The death toll during the genocide in Rwanda has been subject to heated debate, with Alison Des Forges citing 500,000 dead and the government in Rwanda declaring a death toll of over 1.2 million. A more recent survey conducted by sociologist Hollie Nyseth Brehm presents strong data that puts the death toll over 900,000.

\section{References}

African Rights. Rwanda: Not So Innocent - When Women Become Killers (London: African Rights, 1995).

Chrétien, Jean-Pierre. The Great Lakes of Africa: Two Thousand Years of History (New York: Zone Books, 2003).

Des Forges, Alison. Leave None to Tell the Story: Genocide in Rwanda (New York: Human Rights Watch, 1999).

Des Forges, Alison, and David S. Newbury. Defeat is the Only Bad News: Rwanda under Musinga, 1896-1931 (Madison: The University of Wisconsin Press, 2011).

Gourevitch, Philip. We Wish to Inform you that Tomorrow we will be Killed with our Families (New York: Farrar, Straus and Girous, 1998).

Holmes, Georgina. Women and War: Gender, Media, and the Representation of Genocide (New York: I. B. Taurus \& Co, 2014).

Interview Ezechial Sentama. Interview by Sara E. Brown. Kigali, Rwanda, 25 June 2011.

Lemarchand, René. Rwanda and Burundi (New York: Praeger, 1970).

Lemarchand, René. The Dynamics of Violence in Central Africa. (Philadelphia: University of Pennsylvania Press, 2009).

Longman, Timothy. "Rwanda's Paradox: Gender Equality or Emerging Authoritarianism?" In Women in African Parliaments, edited by Gretchen Bauer and Hannah E. Britton, 210-33 (Boulder: Lynne Reinner, 2005).

Mamdani, Mahmood. When Victims Become Killers: Colonialism, Nativism, and the Genocide in Rwanda (Princeton: Princeton University Press, 2001).

Newbury, Catharine. The Cohesion of Oppression: Clientship and Ethnicity in Rwanda, 1860-1960 (New York: Columbia University Press, 1988).

Pieterse, Jan Nederveen. White on Black: Images of Africa and Blacks in Western Popular Culture (New Haven: Yale University Press, 1992).

Powley, Elizabeth. "Strengthening Governance: The Role of the Women in Rwanda's Transition." Women Waging Peace series. October 2003.

Prunier, Gérard. The Rwanda Crisis: History of a Genocide (New York: Columbia University Press, 1995).

Sharlach, Lisa. "Gender and Genocide in Rwanda: Women as Agents and Objects of Genocide," Journal of Genocide Research 1, no. 3 (1999), 387-99. 


\section{History of Rwanda}

United Nations. "Charter of the United Nations, Chapter XI, Article 73." 26 June 1945. Vansina, Jan. Antecedents to Modern Rwanda: The Nyiginya Kingdom (Madison: University of Wisconsin Press, 2004).

Young, Crawford. Politics in the Congo: Decolonization and Independence (Princeton,: Princeton University Press, 1965). 


\section{Mobilization and Militarization}

The horrors of genocide depend upon processes that enable and facilitate the perpetration of violence. Thus, the 1994 genocide was not an event with a clean start and end; rather, it was the result of mobilization and militarization campaigns meant to galvanize action. Combining theoretical models for understanding mass violence and gendered militarization with testimony describing the pre-genocide incitement tactics undertaken by extremists in Rwanda, this chapter analyzes the deliberate efforts of the state, society, and lay leaders that were essential to the manipulation of women's identities in Rwanda and prepared the way for women's involvement in mass atrocities. As gender and militarization expert Cynthia Enloe has observed,

state officials (and those people with cultural influence who have a stake in the current regime's view of the state) are constantly trying to shape citizens' own senses of identity and their senses of their identity's reliance on a state's security.... Both of these processes are gritty, daily, [and] specific in how they each are deeply affected by constructions of masculinity and femininity. ${ }^{1}$

In Rwanda, a deeply entrenched patriarchal system limited the agency of Rwandan women. ${ }^{2}$ Thus, the militarization of women, sensitizing, desensitizing, and mobilizing them to commit acts of violence, was shaped to fit their limited agency and appealed directly to their traditional role in society as subordinate mothers, daughters, wives, and sisters. These militarizing processes are key during periods of conflict and genocide when the perpetration of mass atrocities relies upon widespread complicity, either through commission or omission. And they need not fit conventional understandings of militarization that emphasize masculinized forms of aggression. As noted by Enloe, "militarization can look less like conventional aggressiveness and more like deferential passivity." 3 At the same time, some women resisted the efforts of the state and extremists, and refused to adopt an identity rooted in ethnic hatred and othering. This relationship between the gendered role of women in society and their mobilization leading up to and throughout the genocide was a crucial component of women's participation. 
Political scientists Barbara Harff and Ted Robert Gurr have identified two preconditions for mobilization to mass action that cause humanitarian emergencies: a shared identity and organizations that give expression to both that shared identity as well as the group's aspirations. ${ }^{4}$ Holocaust and genocide studies scholar and psychologist James Waller goes further to explain that "group identities can even become such an important source of self-definition and esteem that other groups are perceived as threats - thus sowing the seeds for intergroup conflict." 5 Gender - assigned by sex and referring to "the social attributes and opportunities associated with being male and female and the relationships between women and men and girls and boys, as well as the relations between women and those between men" - has been identified by feminists as a strong shared identity. ${ }^{6}$ While shared identities may stem from biological certainties, the gender-based group assumptions in Rwanda resulted from stereotyped preconceptions about a woman's status in society and perceived gender roles.

But, as aptly observed by feminist Nira Yuval Davis, "there is a need to differentiate carefully between different kinds of difference." Despite the patriarchal system that dominated Rwanda in the 1990s and subjugated women as second-class citizens, gender was not the only shared identity; ethnicity mattered, too. ${ }^{8}$ Indeed, for most, ethnicity served as the primary marker of group inclusion and exclusion that was continuously molded and exploited by the media, the government, and local leaders. Here, a breakdown of the dynamic and malleable "interlinking grids of differential positionings" of gender and ethnicity in Rwanda is necessary. ${ }^{9}$ The development and manipulation of ethnic identity, in spite of its dominance, was dependent upon and in discourse with gender. For women perpetrators, the shared identity of Hutu was manipulated to supersede any sense of shared identity with Tutsi women. Adding to the heightened sense of urgency and fear that often accompanies militarization of a civilian population, extremist-controlled media were instrumental in promoting both a mainstream and a women-specific embrace of the "threat" of the Tutsi population, especially Tutsi women, and the need for Hutu solidarity even if that meant ethnic violence. In the end, the gendered mobilization was so effective that, as scholar Lisa Sharlach has pointed out, "in 1994 Rwanda, a woman's loyalty to her ethnic group almost always overrode any sense of sisterhood to women of the other ethnic group." ${ }^{\prime 10}$ At the same time, women rescuers rejected the shared identity predicated upon an ethnic-based us (Hutu) vs. them (Tutsi) paradigm. For them, the shared identity of "woman" or "human being" or "Rwandan" or "Christian" (as we know from respondents' narratives) transcended ethnic identity-based division. But an organization that offered expression to this outlying group is missing; instead, a fierce individuality or faith in God appears to have driven women rescuers to reject the ethnic hatred espoused by the media, the government, and various lay leaders, and to risk their lives to rescue Tutsis.

Still, uniformity did not prevail among the women perpetrators or rescuers I interviewed. Women perpetrators were often reluctant to describe their acts of violence, let alone their motivations. I therefore worked within the limited scope of their responses regarding messages of hatred and division from the media and 
local leadership, and the overwhelming fear that accompanied the 1994 genocide. Using words and images, extremists maneuvering for power exacerbated and promoted divisions between Hutu and Tutsi. These manipulations were often gender-specific and took the form of political messages, decrees, radio programs, illustrations, and print materials. The importance of words and images as tools for mobilization looms large. It was similarly difficult to determine overarching motivations for women rescuers, but not due to a reticence to speak. Psychologists Pearl and Samuel Oliner studied rescue during the Holocaust and concluded,

The variation in motivations leading to rescue behavior highlights the important point that the paths to virtue are neither uniform nor standardized. Rather, they represent alternative pathways through which individuals are equipped and disposed to interpret events of moral significance. ${ }^{11}$

Still, certain themes emerged of faith, shared humanity, and the capacity to think critically about messages of hatred and counter them with personal beliefs. Examining first the role of media, local leadership, and fear to encourage perpetration of genocide, this chapter explores the ways that women were mobilized and militarized as women to participate in the genocide or, at the very least, stand by in silence.

\section{Print publications}

Word usage facilitated deadly action in Rwanda. Kangura, a popular print periodical, and the Radio-Télévision Libre des Mille Collines (RTLM), one of Rwanda's primary radio stations leading up to and during the genocide, served the interests of extremist elements within and to the radical right of the ruling political party, the Mouvement Républicain National pour la Démocratie et le Développement (MRNDD), known as the Mouvement Révolutionnaire National pour le Développement (MRND) before multi-party rule was introduced in Rwanda. One woman survivor described how the mobilization affected the school where she worked as a teacher.

We went through hard times. The newspapers, from Kanguka and Kangura [two popular anti-Tutsi publications], were united in using the ethnic weapon to create conflict among the population. There were also political parties... There were people who spent the whole day having discussions, telling people that the enemy was still that of 1959. In short, they incited the killing and extermination of this enemy. At work also, it was not better. The teachers, my colleagues insulted us all day long. We had no peace. ${ }^{12}$

In 1994, questionable data sets assert that between 57.9 and 66 percent of the Rwandan population was literate. ${ }^{13}$ Kangura, which according to historian and human rights activist Alison Des Forges was "one of the most virulent voices of 
hate," 14 was widely circulated, especially in urban centers like the capital of Kigali, and served as the literary lynchpin for genocidal mobilization. Kangura publications repeatedly predicted a wave of violence against the Tutsi and fueled tensions with false headlines about Tutsi betrayers, fifth columnists helping the RPF rebels, and graphic cartoons. Nathan, a child survivor of the genocide, often saw these publications for sale in the streets.

So there was this newspaper - I remember one of them, Kangura, there was Kanguka but there was also Kangura. So Kangura was more on the government's side. So they used to publish all these stories about how Tutsi will die. You would see the headline "The Tutsi will die" in Kinyarwanda. I recall one title in Kinyarwanda was saying that "Aka Batutsi Kashobotsi" you know what that means? Like, "Now Tutsis are Going to Get into Trouble." 15

One crucial piece published by Kangura was the "Hutu Ten Commandments," a list of dos and don'ts for Hutus that pitted the Hutu population against their Tutsi compatriots. Adapted from Joseph Gitera's "Eleven Commandments of the Hutu" drafted in 1959, the "Hutu Ten Commandments" were republished by Hassan Ngeze, the editor of Kangura, in 1990. It served as potent propaganda. People shared hard copies, and direct and indirect oral recitations were repeated throughout Rwanda. ${ }^{16}$ Journalist Philip Gourevitch describes their impact in detail.

"The Hutu Ten Commandments" were widely circulated and immensely popular. President Habyarimana championed their publication as proof of Rwanda's "freedom of the press." Community leaders across Rwanda regarded them as tantamount to law, and read them aloud at public meetings. The message was hardly unfamiliar, but with its whiff of holy war and its unforgiving warnings to lapsed Hutu, even Rwanda's most unsophisticated peasantry could not fail to grasp that it had hit an altogether new pitch of alarm. ${ }^{17}$

The "Hutu Ten Commandments" pushed for Hutu unity through the ethnic othering of the Tutsi population and provided a set of ethnic-specific rules to shape their behaviors and interactions with the Tutsi population. Des Forges noted its role in teaching Hutus "the need to maintain Hutu purity and to avoid contamination from the Tutsi" and its significance as part of a broader strategy to discourage Hutu solidarity with Tutsis. "Discrediting those already in the opposition was not enough; they had to make it unthinkable for others to join them." ${ }^{18}$ And Mamdani notes the significant timing of the publication of the "widely circulated" commandments: they were published shortly after the RPF invasion of Rwanda. ${ }^{19}$

While the significance of this publication is widely acknowledged by scholars and survivors alike, and taken for granted as one of the effective tools used to 
mobilize the community prior to the genocide, it is rare to address the genderbased content of these commandments. In fact, the first three commandments relate specifically to women or appeal directly to Hutu women.

1 Every Hutu male should know that Tutsi women, wherever they may be, work for the interest of their Tutsi ethnic group. As a result, a Hutu who marries a Tutsi woman, befriends a Tutsi woman, or employs a Tutsi woman as a secretary or a concubine shall be considered a traitor.

2 Every Hutu should know that our daughters are more suitable and conscientious in their role as woman, wife, and mother. Are they not beautiful, good secretaries, and more honest?

3 Hutu women, be vigilant, and try to bring your husbands, brothers, and sons back to reason. ${ }^{20}$

These commandments serve as an example of men - men authors and men publishers - thinking and writing about women and delineating ethnic boundaries through Rwandan women. The first commandment labels the Tutsi woman as a dangerous enemy and traitor who is working for a cause that is, according to this publication, counter to Hutu interests. Sowing seeds of gendered fear and threat only further militarized Hutus who had recently experienced the RPF invasion. This message was deliberate and meant not only to "warn" Hutu men and women of the Tutsi threat; it was also intended to sow intra-gender divisions by othering Tutsi women in particular. By demonizing and othering Tutsi women, the shared identity of "woman" that may have bound individuals across ethnic boundaries was weakened, if not broken.

Dehumanization and demonization of Tutsi women was a recurring theme that often included an element of hyper-sexualization in Kangura publications and on the radio. Gourevitch notes that, "The first three commandments addressed the stubborn perception ... that the beauty of Tutsi women surpasses that of Hutu women. According to Ngeze's protocols, all Tutsi women were Tutsi agents." 21 Political scientist René Lemarchand has noted that, "Tutsi women ... were a favorite target of Hutu cartoonists in search of pornographic effect" and that cartoons were utilized by the media to portray Tutsi women as sexually deviant and inhuman. ${ }^{22}$ And feminist scholar Catherine MacKinnon has observed that "vicious sexualization and denigrating sexual stereotyping of Tutsi women was a staple on the radio and in newspapers preceding and throughout the atrocities. ${ }^{.23}$ In Rwandan culture, a woman's modesty and chastity were (and remain) cornerstones of society. Gender theorist Judith Butler noted that, "Performing one's gender wrong initiates a set of punishments both obvious and indirect." ${ }^{24}$ The sexual deviancy alleged and depicted in cartoons and further propagated by Ngeze when he republished the "Hutu Ten Commandments" was considered abhorrent and contributed to a belief that Tutsi women were neither women nor human beings; as a result, they deserved to be ostracized from society and they deserved violent reproach. The sexuality of Tutsi women was distorted, hyper-inflated, and manipulated in order to galvanize Hutu women into 
committing, or at the very least ignoring, atrocities against them. This dehumanization and hyper-sexualization of Tutsi women contributed directly to the genocidal rape that ensued during the genocide in $1994 .{ }^{25}$ One Human Rights Watch report found that,

During the Rwandan genocide, rape and other forms of violence were directed primarily against Tutsi women because of both their gender and their ethnicity. The extremist propaganda which exhorted Hutu to commit the genocide specifically identified the sexuality of Tutsi women as a means through which the Tutsi community sought to infiltrate and control the Hutu community. This propaganda fueled the sexual violence perpetrated against Tutsi women as a means of dehumanizing and subjugating all Tutsi. ${ }^{26}$

Thus, the first commandment was part of a deliberate and widespread campaign of dehumanization and demonization of Tutsi women that mobilized Hutu men and women to perpetrate particularly violent crimes against them.

The second commandment follows a similar logic, elevating Hutu women and serving to boost their sense of identity and worth at the expense of Tutsi women. This is a key component of the mobilization-to-violence process. Valorizing a group builds its "us" identity and brought Hutu women to look at their in-group differently. Psychologist Ervin Staub has suggested that this process of becoming "us," "leads to a preference for us over 'them.' It also makes it easier and more likely for us to devalue them." ${ }^{, 27}$ As such, it is just as important to construct a sense of "us," the inside group, using positive terms as it is "them," the outside group, using negative terms. Thus, Ngeze in the second commandment celebrates and praises Hutu women ("us") for their suitability, their beauty, and their honesty and suggests the inferiority and unsuitability of Tutsi women ("them").

The third commandment is a direct appeal to women's agency and calls upon Hutu women to take action, tasking them to stand up to Hutu men and make them "see reason." This appeal to and sanctioning of women's agency is significant given the patriarchal system that dominated Rwandan culture and restricted the agency exercised by Rwandan women. In a society where women were denied by law the right to inherit land and where women's participation in politics was marginal, the notion of women's agency depended upon male permission and was framed by what was considered "acceptable" behavior for a woman in the existing social construct. There are many ways for women to express agency, even when subjected to discrimination and marginalization. But here, in the "Hutu Ten Commandments," Ngeze relieved women of many of the societal constraints that demanded passivity and called for narrow expressions of agency. Indeed, the Commandments encouraged, empowered, and incited women to act in order to save Hutu men from succumbing to a perceived threat. Still, Cynthia Enloe's warning that "the idea that war is a liberating time for women can be seductive" 28 is relevant. Women perpetrators' experiences during the genocide in Rwanda cannot be characterized as fully liberating; women were 
granted just a modicum of agency. Nonetheless, this sanctioning of action and its militarizing effects was in itself revolutionary.

That the "Hutu Ten Commandments" evoked the Ten Commandments of the Hebrew Bible was no coincidence. The title, structure, and tone were designed to mirror a biblical text in a country where over 90 percent of the population was (and is) Christian. ${ }^{29}$ In a deeply religious country such as Rwanda, the binding nature of the "Hutu Ten Commandments" was not lost upon its intended audience. The message of hatred and ethnic exclusion was, according to scholars Matthias Bjørnlund, Eric Markusen, Peter Steenberg, and Rafiki Ubaldo, “conveyed through and legitimated by strong Christian imagery - the Ten Commandments, i.e., Christian basic law." ${ }^{30}$ The order of the commandments was no coincidence either. The most important of the ancient Ten Commandments is the first, which is fundamental to monotheistic faith, and includes the statement, "I am the Lord Your God." The following two commandments relate directly to the first, as they concern worship and practice in a monotheistic faith. These first three commandments provide the foundation of monotheism and are key to Christianity. The first three commandments of the "Hutu Ten Commandments" relate to women and sanction their agency in rising up against the perceived threat of the Tutsi population. Thus, the significance of the "Hutu Ten Commandments" as a mobilizing and militarizing tool lays not only in its content but also in the order of the commandments and in its symbolic relevance.

\section{Radio}

A Ugandan journalist once joked to me, "If you want to keep a secret from Rwandans, put it in print. If you want everyone to know, put it on the radio." If print media were successful in mobilizing and militarizing the Rwandan population, including women, the radio was even more effective as it was able to reach a wider audience simultaneously and directly. ${ }^{31}$

Radio Télévision Libre des Mille Collines (RTLM) radio, born out of dissatisfaction with Rwanda Radio's more pluralistic message, quickly gained popularity and was instrumental in spreading genocidal messages to a broad audience throughout the country. ${ }^{32}$ The role of the radio in perpetuating genocidal ideology and mobilizing Hutus to participate in the genocide was such that, during the International Criminal Tribunal for Rwanda (ICTR) "media trials," two managers of RTLM, Ferdinand Nahimana and Jean-Bosco Barayagwiza, were convicted. ${ }^{33}$ As the judgement noted,

Demonizing the Tutsi as having inherently evil qualities, equating the ethnic group with "the enemy" and portraying its women as seductive enemy agents, the media called for the extermination of the Tutsi ethnic group as a response to the political threat that they associated with Tutsi ethnicity. ${ }^{34}$

The station used popular music laced with anti-Tutsi sentiments, interactive programs that discussed the Tutsi "threat" and resembled casual conversations held 
at a bar, radio soap dramas, and charismatic radio announcers in order to influence the population and disseminate a message of hate and fear. And for audiences unable to access or comprehend print media, RTLM regularly read excerpts, including the "Hutu Ten Commandments," over the airwaves. ${ }^{35}$ Overall, the RTLM radio programs were more masculine in nature, as women were traditionally excluded from bar conversations and were not readily given a public forum where they could speak their mind. Still, the radio programs, music, and messages were popular with men and women alike throughout Rwanda and the RTLM radio station took care to include programming that spoke to women as well. The use of dehumanizing terminology that likened Tutsis to cockroaches and snakes was a powerful radio tool. Lynn, incarcerated for participating in the mob killing of a child, explained that, "We used to hear RTLM radio. They used to say that Tutsis are cockroaches. They used to sensitize the population to kill and eliminate cockroaches, they used to say that Tutsis are cockroaches or they are snakes. ${ }^{" 36}$

Perhaps in an effort to appeal to women listeners, RTLM's chief editors hired Valerie Bemeriki, a well-known member of the MRNDD political party and writer for its two newspapers, Umurwanashyaka and Interahamwe, as a radio news broadcaster. She was notorious for her fast pace and passionate broadcasts which, as Des Forges observed, "increased when she had violence to report." ${ }^{37}$ Now incarcerated in Rwanda for genocide crimes, Bemeriki readily affirmed the significant influence of RTLM and her programs, describing the gifts and compliments she received for her transmissions before and during the genocide. While she expressed remorse for her role in promoting the killings - stating that, "I regret my programs and shows that caused the death of thousands of people" - she was less receptive to assertions that she was a role model for Hutu women who perpetrated genocide. She hedged, claiming, "It might be possible, I cannot deny it," and asserting,

I was not the only one saying that [motivating Hutu women to kill]. There were men who were saying it, too. The other thing is that if they [Hutu women] killed, it is because they also wanted to do it themselves.... You cannot tell someone to do something that they don't want to do. They did it because they believed in it, it was in their head." ${ }^{38}$

She simultaneously confirmed and contested the very idea of RTLM influence and her own influence on Hutu women as a result. But staff at AERG disagreed with her contradictory assessment. Not only did they cite RTLM as the most important mobilizing agent for the killing of Tutsis, they stressed in particular the influence of Valerie Bemeriki.

Because she [Valerie Bemeriki] was a woman, it had a role. First, when the woman, psychologically, when the woman listens to that kind of emission on the radio, they get mobilized of course. Because they know that it's not only a job of the man, then they participate also. Because they know that there [are] other women who are doing something, then we have to do also something. ${ }^{39}$ 
The fact that Bemeriki was a woman broadcasting nationwide and speaking out, calling to task and to arms the people of Rwanda regardless of gender, and in a country where men were considered dominant, motivated men to become involved and take leadership positions so as to maintain and assert their dominance as men. But Bemeriki also spoke from a gendered perspective that women could relate to and understand; as a woman, she could access and influence Rwandan women due to their shared gender, offering women a sense of empowerment and justification that may otherwise have been lacking.

Bemeriki and the journalists at RTLM were not alone in their efforts. Musicians like Simon Bikindi also helped to popularize and triangulate the print and radio media's anti-Tutsi sentiments through music. Bikindi, a singer-songwriter and staunch supporter of the MRNDD, endorsed the extremist agenda against the Tutsis and was incorporated into the party's genocidal plans. As staff at the Ministre du Sport et de la Jeunesse (Ministry of Sport and Youth), he produced songs that championed Hutu power, diminished the suffering of the Tutsis, and propagated suspicion and fear of the Tutsi. In an effort years later to marginalize her own influence, Bemeriki referenced the significance of Bikindi's songs in particular. "Also at RLTM, it was not only about what we were saying. We would play songs inciting hatred between Hutus and Tutsis and songs which promoted the 1959 revolution ideology. Most of them were sung by Bikindi." ${ }^{40}$ Nathan, a survivor of the genocide, remembers Bikindi's songs well.

And then there was this Bikindi. His songs used to be played on this radio a lot, most of the time.... There is a song I remember ... he was saying "some people, they don't get involved, they are moderate, they just want to get into this." He was trying to encourage them but in a song. But he would sing it now, you know, he has own way that he would sing that, not everyone would immediately understand that - actually, after, afterwards, that's when I tried to think about that and, "Ah, this is what he was saying, this is what he meant." 41

Bikindi's songs were so popular that, as Des Forges observed, "when patrols went out to kill, they went off singing the songs heard on RTLM, such as those of the popular Simon Bikindi." 42 Bikindi's music appealed to women and men alike. Bikindi's popularity, the content of his songs, and his broad fan base appealing to young men and women with the use of rap and multi-lingual lyrics, and to older people with the use of traditional instrument and tunes - were all part of a broader deliberate strategy by the planners of the genocide.

But not everyone was convinced. As the genocide spread throughout Rwanda, Josephine Dusabimana heard the radio announcers encouraging her fellow Hutus to participate in the mass murder of the Tutsis.

The killings had intensified and also on the radio they were really sensitizing the Hutus to kill the Tutsis, like, giving them morale to do the killings. They said on the radio that there is not any other enemy right now - the greatest enemy they had was a Tutsi. ${ }^{43}$ 
But Josephine did not believe that her neighbors were suddenly the enemy and instead took in two Tutsis, later securing them safe passage across Lake Kivu to the Democratic Republic of the Congo.

\section{Local leadership}

As influential as the media were, most rural Rwandan communities orientated themselves around their local hill as the primary nexus of society and were not so intimately connected with inhabitants of other hills, let alone the capital city of Kigali. As a result, local leaders were exceptionally powerful and used their traditional, political, or religious authority to persuade and mobilize their followers. As noted by Rwanda scholar Lee Ann Fujii, "Even in cases where coercion was less prominent, the authorities wielded enormous power to mobilize people - to convince them to join the violence of their own accord."44 Membership in political parties thus served as a ready vehicle for mobilization and militarization. While throughout the 1990s men were more readily recruited - or even compelled - by local leaders to join political parties, women were sometimes included, frequently without their understanding or explicit consent. Of the 20 women perpetrators asked if they were members of a political party, four confirmed their membership in the MRNDD or the Mouvement Démocratique Républicain (MDR, another pro-Hutu with an extremist element) parties. Two women were evasive: one claimed she may have been unknowingly registered by party officials, neighbors, or her sons, and another refused to provide a definitive answer. Several women sought to justify their membership. Deena explained that although she was a member of a political party, she was registered without her knowledge or consent since she did not know how to read or write. In addition, she claimed to have learned of the pre-genocide political meetings only during Gacaca proceedings; she asserted this was possible because political meetings "were only held by men in the community." 45

The male-dominated nature of party meetings was also confirmed by a woman rescuer, Janet, who narrated her own participation in partisan politics using frank terms. Janet readily admitted that she had been a member of the MRNDD political party in order to maintain her position as a teacher in a nearby elementary school. Still, Janet rejected the party line and rescued over a dozen children during the genocide and explained that, "Of course when I used to hear what was being said on the radio and the newspapers, I never knew it would happen exactly the way they said it."46 And while Janet was to some degree aware of what was being espoused by the party leaders, she did not attend political meetings and hear their exclusionary messages firsthand for the same reason Deena adduced above: at that time, it was not customary for women to attend political meetings. This may also explain why the other 15 women interviewed did not admit to any political party membership; customarily, men were actively recruited, even compelled to join, while women were largely ignored. Here we find, on the one hand, a gender hierarchy within the mobilization and militarization processes that continued to privilege men and limit women's access to 
public/political spheres. On the other hand, it is evident that the overall mobilization and militarization process, a process dominated by men, challenged prevailing patriarchal norms and afforded women more agency. This dichotomous push-pull effect contributed to the constrained forms of agency we will analyze in the forthcoming chapters. Since Janet did not have a husband who would have been more likely to attend political meetings, she did not hear the rhetoric repeated in the rallies and meetings, nor was she active participation in the genocide expected of her. Still, women could participate in party politics if they chose, as was evidenced by the women perpetrators who claimed membership.

One particularly infamous MRNDD political meeting that resonated from its locale throughout the country took place on 22 November 1992. Leon Mugesera, then vice-president of the MRNDD in the Gisenyi prefecture and a key government figure, took the stage and delivered what is now known as the "Do not let yourselves be invaded" speech. He used dehumanizing language, referring to the RPF forces as inyenzi (cockroaches), cited passages from the Bible about violence and retribution, and spoke enthusiastically of exterminating, crushing, and liquidating political opponents and Tutsis alike. His message was clear. "I am telling you [a Parti Libéral, or PL party member] that your home is in Ethiopia, that we are going to send you back there quickly, by the Nyabarongo [river]." ${ }^{\prime 4}$ The significance of this sentence as a mobilizing moment cannot be overstated. The PL member reference was code for a Tutsi, deliberately painting the PL party as a Tutsi party. The Nyabarongo river reference was deliberate as well, as it invoked memories of prior massacres of Tutsis during the independence period when Tutsis were murdered by Hutus and their bodies dumped into the river. The Second Vice Coordinator of AERG, a student genocide survivor organization in Rwanda, remembered that Mugesera "made a popular speech in 1992. He made a propaganda asking Hutus to act by the 'short cut' [the Nyabarongo river] ... saying, "we will push Tutsis in the short cut to return to Abyssinia." "48 The reference to Ethiopia was calculated, too. Drawing upon the Hamitic myth, some alleged that the Tutsis were foreigners from Ethiopia who had invaded Rwanda centuries earlier and usurped the country from its native population, the Hutus.

Mugesera's speech was recorded and disseminated throughout the country via radio broadcasts and print publications. While some were so shocked by Mugesera's violent rhetoric that the Minister of Justice at that time even issued a warrant for his arrest, others were galvanized. And so I took for granted that Mugesera's influence and speech would be discussed openly by women perpetrators. Yet none of the women interviewed spoke about this speech or brought up Mugesera. This took me by surprise. Instead, they typically referenced the names of local leaders and spoke in more general terms about the influence of unnamed members of the regional and national leadership. Reference to identified leaders such as Mugesera and their role in propagating genocide was more likely in conversations with community and government stakeholders, who provided a wider lens on the genocide. Their view reinforced the role of the local hill as the axis of rural society and the influence of local leaders who undoubtedly were, in turn, influenced by their superiors. 
Some recalled that local political leaders reiterated and thus reinforced the dehumanizing terms heard on the radio, often during meetings organized after church. One perpetrator recalled, "I used to hear the local leaders who used to talk about cockroaches, snakes, and stuff like that. They would come up with names for the Tutsi." ${ }^{, 49}$ Kristen, another perpetrator who, upon review of her Gacaca court transcripts, was found to have lied about her participation in the genocide, claimed no prior knowledge of the planned genocide, yet she offered a poignantly detailed description of inter-party rivalries and anti-Tutsi violence in her area leading up to April 1994. And though she denied any wrongdoing during the genocide, she nevertheless recalled anti-Tutsi rhetoric and incitement of violence on the radio, including the accusation that the Tutsi rebels had murdered President Habyarimana. ${ }^{50}$ Cindy, incarcerated at the Jali TIG facility, recounted her experience in church where "people used to come and they would prophesize that there is going to be a war, you should be ready.... They used to say that 'the Tutsis are going to be killed.' ",51

Another perpetrator, Kathleen, recalled not only the frictions in her community but one religious leader's failed efforts to curb the violence. "Before this war started, there used to be some small instability in the community. They would come and maybe set someone's house on fire or take their cattle or goats, stuff like that." ${ }^{, 52}$ As tensions escalated during the pre-genocide period, Kathleen's priest chastised the community for its mobilization toward violence and killing.

What I remember is the Sunday before the war started, we were supposed to go and pray. We went to church on Sunday as usual and then the priest told us to go and pray from our homes because amatwi ari murupfuye, nyabgo byumva.

This Kinyarwanda proverb translates as "the ears that have death in them, they will never hear me." The priest was admonishing his parishioners for their decision to embark on a path of destruction and violence, and therefore refused to preach his sermon. By holding his parishioners accountable, the priest opposed the local leadership and put himself at grave risk. He was murdered when the genocide began a few days later. ${ }^{53}$

\section{Fear}

By the time the genocide began in April 1994, this multi-faceted campaign of hatred employed by the extremists had taken root, indoctrinating Hutu men and women against their Tutsi compatriots. One survivor, Marjorie, recalled that prior to the genocide she regularly encountered hostility at the nutrition center where she worked and in the marketplace.

I was always in contact with women who brought their children there [to the nutrition center]. Among them, there were a lot of Hutu women who were 
mean and came with bad intentions, unhappy. When we went to buy something in a shop, they answered us rudely, they mistreated us. In other words, we were marginalized without being able to object and this was how they showed us that they considered us enemies. We had a neighbor who came to meetings and said each time, "You are going to die soon." 54

As we have seen, a range of tools were utilized to sensitize women to participate in the genocide, but the most important for most men and women perpetrators was fear. The alliance that formed between RTLM radio and Kangura ensured that the population was subjected to image, print, and radio influences that invoked terror and anxiety. The propagation and manipulation of this fear took place on all levels of society and in every sphere of influence, from the military to the lay leadership, and from the public to the private. Fear is a powerful mobilizing agent that was directed toward women specifically so that they would, as social anthropologist Simon Harrison has observed, "see themselves as under threat not only from those who differ from them ... but also from those 'ethnic others who resemble them, or who seem to identify with them too closely." "'55 Fear is an essential component of the militarization package; it is necessary to convince the target audience that the world is a dangerous place and the use of force a necessary defensive measure. Through the use of mass media and government leaders, messages of fear and divisionism mobilized men and women in preparation for the genocide in Rwanda. These included the genderspecific mobilization of Hutu women in order to provide a sanctioned, albeit constrained, space for women's perpetration during the genocide.

The genocide was described by many respondents as a period of pandemonium. Fear, shouting, running, gunfire, killing, and chaos are themes repeated in interviews with witnesses of the genocide, including perpetrators, survivors, and rescuers. One woman perpetrator noted, "First of all I was scared because of what I was hearing and also hearing that people were killing each other," ${ }^{, 56}$ while another agreed, "I was scared, of course, because just the matter of hearing what was going on in the country." ${ }^{57}$ Cindy explained, "All of us were scared in general, it's not only the Tutsis. It was all of us." ${ }^{, 58}$ Rachel, a survivor, recalled when the genocide reached her hill outside of Kibuye, "we started hearing people screaming and shouting. I saw people passing by our home, running with machetes, chasing people who are Tutsis." ${ }^{\circ 59}$ In Nyarugunga, a neighborhood close to the former president's home near the airport, the Hutu extremists embedded in the area began killing the day after the president's plane was shot down. This terrified Rosanne into action. When intense fighting broke out between the RPF soldiers and a nearby government military barrack, Rosanne watched the neighborhood fall into chaos.

At some point, because things had changed completely, people were just running, even me. Even those who were hiding in houses, they were moving out of the houses and trying to find a safe haven. There was no trust. I tried to find where to hide. ${ }^{60}$ 
Fear, chaos, and mistrust galvanized many who were swept up into acts of perpetration, obliterating their values alongside the rule of law and state institutions. The resulting hysteria and savagery made both resistance and rescue increasingly difficult.

In spite of their shared culture, religion, language, nationality, and gender with Tutsi women, Hutu women were pressed to view themselves as threatened by the Tutsi population, especially Tutsi women. One witness noted the sexual threat that Tutsi women represented led Hutu women to celebrate and encourage their mass killing because "now these [Hutu] ladies were saying now we have husbands because these [Tutsi women] will be killed." 61 This alleged threat built upon the hyper-sexualized rhetoric propagated by the media and majority-male leadership that portrayed Tutsi women as deviant seductresses in direct competition with Hutu women for eligible Hutu men.

Interestingly, some women perpetrators claim to have heard nothing before the genocide. In their interviews, they treat the violence as though it was an unexpected storm over which they had little control. As we shall see in Chapter 5, "Perpetrators," it is possible that their denial of pre-genocide mobilization and militarization is linked to their reluctance to discuss their crimes during the genocide or outright denial of their complicity.

Throughout the perpetration of the 1994 genocide, and even after key members of the print and radio media were forced to flee the RPF advance, the media continued to spread a message of hatred and fear and to openly support the mass killing of Tutsis. A former staff member at the Gacaca courts and coordinator for the Kigali Genocide Memorial explained that the efforts to incite genocide continued throughout April, June, and early July, and was not limited to Hutu men.

But during genocide, in different media, especially in newspapers like Kangura or radio, especially the radio called RTLM, they like to say all the people have to work, also women. They [the women] don't have to stay at the house being occupied with other tasks, they have to go to find the cockroaches.... So that's why also sometimes themselves they have to act ... sometimes some women participated to show that they are able to do the things like men. ${ }^{62}$

Print media continued to churn out hate propaganda and often turned to the airwaves in order to reach regions that were no longer receiving their publications. And the radio continued to monopolize the airwaves with messages of ethnic hatred, paranoia, and justification. Radio journalists often centered on the genocide without addressing it directly, focusing instead upon Hutu grievances, misinformation, and incitement to kill Tutsis. Programs included radio interviews with militia members at checkpoints, alleged "spies" for the RPF, talk show programs with guest speakers from the government and media, and on-air readings of letters submitted by Rwandan citizens that covered everything from the war to greetings to friends and family. In addition, lists were read of Tutsis and 
moderate Hutus targeted by the government, sometimes with physical descriptions and rumored locations in order to facilitate their capture and murder. Music played frequently throughout broadcasts, offering a cheerful reprieve from programming that was otherwise frightening and violent. Women were represented in these programs, weighing in on matters of security, foreign policy, allegations of RPF abuses, and also submitted letters. ${ }^{63}$ One such letter, penned by Marie Louise Mukobwajana, voiced support for the Rwandan military, condemned the RPF for the current violence, and claimed that "the remaining cockroaches should accept negotiations before they are finished up. Our soldiers are hunting them in order to kill them all." ${ }^{\circ 4}$

Bemeriki was with RTLM throughout this period, working to reassure listeners that the RPF was to blame for the violence and unrest, and to imbue the extremist leadership with feigned victimhood. On 17 May 1994, she transmitted the following message.

All the people who were killed in the country are the victims of the RPF. It is the cockroach Inkotanyi [at the time, used as a derogatory term for the RPF rebel group] who killed them and nobody else. That is why the Presidential Guard should not be disbanded. It did nothing wrong. That is why the government should not be dissolved. It was legally set up and did not carry out any killings. It was rather set up to re-establish the security that the RPF had troubled. ${ }^{65}$

By that point, nearly six weeks into the genocide, it was clear that the Interahamwe, aided by the Rwandan military and the extremist leaders of the government, were intent upon annihilating the Tutsis. But in order to maintain a façade of lawfulness and ensure a continuation of the genocide throughout Rwanda, the leadership, aided by the media, still attempted to cover up their crimes and lay blame for the violence and widespread instability on the war with the RPF.

\section{Notes}

1 Cynthia Enloe, e-mail message to author, 12 September 2011.

2 Because this research focuses on women, it does not address how this deeply entrenched patriarchy influenced men, though it clearly did shape how men exercised agency as well.

3 Cynthia Enloe, Globalization and Militarism: Feminists Make the Link (New York: Rowman \& Littlefield Publishers, 2007): 5.

4 Barbara Harff and Ted Robert Gurr, "Systematic Early Warning of Humanitarian Emergencies," Journal of Peace Research 35 no. 5 (September 1998): 551-79.

5 James Waller, Becoming Evil: How Ordinary People Commit Genocide and Mass Killing, 2nd ed. (New York: Oxford University Press, 2011): 243.

6 United Nations Entity for Gender Equality and the Empowerment of Women, "Concepts and Definitions" (2001), www.un.org/womenwatch/osagi/conceptsandefinitions. htm.

7 Nira Yuval Davis, "Intersectionality and Feminist Politics," European Journal of Women's Studies 13, no. 3 (2006): 199. 
8 Other identities mattered as well, including region of origin, religion, clan, and political party membership.

9 Nira Yuval Davis: 199.

10 Lisa Sharlach, "Gender and Genocide in Rwanda: Women as Agents and Objects of Genocide," Journal of Genocide Research 1, no. 3 (1999): 388.

11 Samuel P. Oliner and Pearl M. Oliner, The Altruistic Personality: Rescuers of Jews in Nazi Europe: What Led Ordinary Men and Women to Risk Their Lives on Behalf of Others? (New York: The Free Press, 1988): 220.

12 AVEGA interview A 11 "Torri," retrieved in Kigali, June 2011.

13 This range is estimated based upon conflicting data provided by the UNESCO Institute for Statistics and Des Forges. See "Adult and Youth Literacy, 1990-2015: Analysis of Data for 41 Selected Countries," UNESCO Institute for Statistics (2012): 13; and Alison Des Forges, Leave None to Tell the Story: Genocide in Rwanda (New York: Human Rights Watch, 1999): 67. These findings are questionable for a number of reasons. While literacy is not necessarily directly tied to formal schooling, there is a positive correlation between schooling and literacy. These statistics conflict with the overall low level of education found among women perpetrators. Given the cost of schooling in 1994 and the hard choices parents had to make when prioritizing education, I believe girls were less likely to be afforded the opportunity to learn in a formal school environment. Still, Des Forges notes on p. 67 that "those who knew how to read were accustomed to reading for others. In many cases, the written word was underscored by cartoons, most of which were so graphic that they could not be misinterpreted."

14 Des Forges: 66.

15 Interview S 5 "Nathan," interview by Sara E. Brown, Kigali, Rwanda, 12 February 2014.

16 If political scientist Scott Straus remains dubious that the "Hutu Ten Commandments" were widely diffused in rural areas and thus an effective mobilization tool, Human Rights Watch refers to them as "notorious." The publication and diffusion of this particular publication also played a critical role in the conviction of Hassan Ngeze, editor of Kangura and author of the reprinted version, by the International Criminal Tribunal for Rwanda in the famously dubbed "media trials."

17 Philip Gourevitch, We Wish to Inform you that Tomorrow we will be Killed with our Families (New York: Farrar, Straus and Girous, 1998): 88.

18 Des Forges: 83.

19 Mahmood Mamdani, When Victims Become Killers: Colonialism, Nativism, and the Genocide in Rwanda (Princeton: Princeton University Press, 2001): 190.

20 Paul Bartrop and Samuel Totten, "Hutu Ten Commandments," in Dictionary of Genocide: Volume 1: A-L (Westport: Greenwood Press, 2008): 200-1.

21 Gourevitch: 88.

22 René Lemarchand, The Dynamics of Violence in Central Africa (Philadelphia: University of Pennsylvania Press, 2009): 61.

23 Catherine MacKinnon, Are Women Human? And Other International Dialogues (Cambridge: The Belknap Press of Harvard University Press, 2006): 226.

24 Judith Butler, "Performative Acts and Gender Constitution: An Essay on Phenomenology and Feminist Theory," Theatre Journal 40, no. 4 (December 1988): 528.

25 Similarly, ethnic difference was sexualized by the media during the war in the former Yugoslavia. See Dubravka Žarkov, The Body of War: Media, Ethnicity, and Gender in the Break-Up of Yugoslavia (Durham: Duke University Press, 2007).

26 Binaifer Nowrojee. "Shattered Lives: Sexual Violence during the Rwandan Genocide and its Aftermath," Human Rights Watch, September 1996.

27 Staub: 209.

28 Cynthia Enloe, The Curious Feminist: Searching for Women in a New Age of Empire (Los Angeles: University of California Press, 2004): 133. 
29 A 2013 U.S. Department of State "International Religious Freedom Report" estimates that,

the population is 56.5 percent Roman Catholic, 11.1 percent Seventh-day Adventist, 26 percent other Protestant denominations, 4.6 percent Muslim, and 1.7 percent no religious beliefs. There are approximately 36,000 Jehovah's Witnesses, and several small religious groups constitute less than 1 percent of the population, including animists, Baha'is, and a very small Jewish community consisting entirely of foreigners.

For more information, visit the U.S. Department of State's Bureau of Democracy, Human Rights and Labor website.

30 Matthias Bjørnlund, Eric Markusen, Peter Steenberg, and Rafiki Ubaldo, "The Christian Churches and the Construction of a Genocidal Mentality in Rwanda." In Genocide in Rwanda: Complicity of the Churches? edited by Carol Rittners, John K. Roth, and Wendy Whitworth (St. Paul: Paragon House, 2004): 158.

31 Des Forges: 67.

32 Here again, dubious statistics published by the UNESCO Institute for Statistics (pp. 14-15) indicate that only 57.9 percent of women and 59.9 percent of men were literate in 1990.

33 ICTR Verdict, "The Prosecutor v. Ferdinand Nahimana, Jean-Bosco Barayagwiza, and Hassan Ngeze," 3 December 2003.

34 Ibid.: paragraph 72.

35 Simone Monasebian, "The Pre-Genocide Case Against Radio-Télévision Libre des Mille Collines." In The Media and the Rwanda Genocide, edited by Allan Thompson (London: Pluto Press, 2007): 322.

36 Interview G 9 "Lynn," interview by Sara E. Brown, Ngoma, Rwanda, 14 February 2014.

37 Des Forges: 70.

38 Interview Valerie Bemeriki, interview by Sara E. Brown, Kigali, Rwanda, 26 March 2014.

39 Interview Omar Ndiyeze and Richard Rugira, interview by Sara E. Brown, Kigali, Rwanda, 15 June 2011.

40 Interview Valerie Bemeriki.

41 Interview S 5 "Nathan".

42 Des Forges: 315.

43 Interview R 6 Josephine Dusabimana, interview by Sara E. Brown, Kibuye, Rwanda, 20 February 2014.

44 Lee Ann Fujii, Killing Neighbors: Webs of Violence in Rwanda (Ithaca: Cornell University Press, 2006): 90.

45 Interview G 17 "Deena," interview by Sara E. Brown, Jali, Rwanda, 16 February 2014.

46 Interview R 5 "Janet," interview by Sara E. Brown, Kibuye, Rwanda, 20 February 2014.

47 Des Forges: 85.

48 Interview Omar Ndiyeze and Richard Rugira.

49 Interview G 9 "Lynn".

50 Interview G 12 "Kristen," interview by Sara. E. Brown, Ngororero, Rwanda, 21 February 2014.

51 Interview G 18 "Cindy," interview by Sara E. Brown, Jali, Rwanda, 16 February 2014.

52 Interview G 14 "Kathleen," interview by Sara E. Brown, Ngororero, Rwanda, 21 February 2014.

53 Ibid. 


\section{Mobilization and Militarization}

54 AVEGA interview A 3 "Marjorie," retrieved in Kigali, June 2011.

55 Simon Harrison, "Identity as a Scare Resource," Social Anthropology 7, no. 3 (1999): 250.

56 Interview G 4 “Jennifer," interview by Sara E. Brown, Muhanga, Rwanda, 30 June 2011.

57 Interview G 3 "Lucy," interview by Sara E. Brown, Muhanga, Rwanda, 30 June 2011.

58 Interview G 18 "Cindy."

59 Interview S 7 "Rachel," interview by Sara E. Brown, Kigali, Rwanda, 5 March 2014.

60 Interview R 15 "Rosanne," interview by Sara E. Brown, Kanombe, Rwanda, 29 April 2014.

61 Interview D E, interview by Sara E. Brown, Kigali, Rwanda, 24 June 2011.

62 Interview Emmanuel Nshimyimana, interview by Sara E. Brown, Murambi, Rwanda, 29 June 2011.

63 For a sample of RTLM transmissions in English, French, and Kinyarwanda, visit the Genocide Archive of Rwanda website: http://genocidearchiverwanda.org.rw/index. php/Category:Audio_Transcripts.

64 ICTR-99-52-T translated transmission of RTLM broadcast on 16-17 May 1994, retrieved from the Genocide Archive of Rwanda, http://repositories.lib.utexas.edu/bitstream/handle/2152/7182/unictr_rtlm_0002_eng.pdf? sequence $=2$.

65 ICTR-99-52-T translated transmission of RTLM broadcast on 17 May 1994, retrieved from the Genocide Archive of Rwanda, http://genocidearchiverwanda.org.rw/index. php?title=Unictr_Rtlm_0008_Eng\&gsearch=.

\section{References}

AVEGA interview A 3 "Marjorie." Retrieved in Kigali, June 2011.

AVEGA interview A 11 "Torri." Retrieved in Kigali, June 2011.

Bartrop, Paul, and Samuel Totten. "Hutu Ten Commandments," in Dictionary of Genocide: Volume 1: A-L, 200-1 (Westport: Greenwood Press, 2008).

Bjørnlund, Matthias, Eric Markusen, Peter Steenberg, and Rafiki Ubaldo. "The Christian Churches and the Construction of a Genocidal Mentality in Rwanda." In Genocide in Rwanda: Complicity of the Churches? edited by Carol Rittners, John K. Roth, and Wendy Whitworth, 141-68 (St. Paul: Paragon House, 2004).

Butler, Judith. "Performative Acts and Gender Constitution: An Essay on Phenomenology and Feminist Theory," Theatre Journal 40, no. 4 (December 1988): 519-31.

Des Forges, Alison. Leave None to Tell the Story: Genocide in Rwanda (New York: Human Rights Watch, 1999).

Enloe, Cynthia. The Curious Feminist: Searching for Women in a New Age of Empire (Los Angeles: University of California Press, 2004).

Enloe, Cynthia. Globalization and Militarism: Feminists Make the Link (New York: Rowman \& Littlefield Publishers, 2007).

Enloe, Cynthia. E-mail message to author. 12 September 2011.

Fujii, Lee Ann. Killing Neighbors: Webs of Violence in Rwanda (Ithaca: Cornell University Press, 2006).

Gourevitch, Philip. We Wish to Inform you that Tomorrow we will be Killed with our Families (New York: Farrar, Straus and Girous, 1998).

Harff, Barbara and Gurr, Ted Robert. "Systematic Early Warning of Humanitarian Emergencies," Journal of Peace Research 35, no. 5 (September 1998): 551-79.

Harrison, Simon. "Identity as a Scare Resource.” Social Anthropology 7, no. 3 (1999): 239-51. 
ICTR-99-52-T translated transmission of RTLM broadcast on 16-17 May 1994. Retrieved from the Genocide Archive of Rwanda. http://repositories.lib.utexas.edu/bitstream/handle/2152/7182/unictr_rtlm_0002_eng.pdf?sequence $=2$.

ICTR-99-52-T translated transmission of RTLM broadcast on 17 May 1994. Retrieved from the Genocide Archive of Rwanda. http://genocidearchiverwanda.org.rw/index. php?title=Unictr_Rtlm_0008_Eng\&gsearch=.

ICTR Verdict. "The Prosecutor v. Ferdinand Nahimana, Jean-Bosco Barayagwiza, and Hassan Ngeze." 3 December 2003.

Interview D E. Interview by Sara E. Brown. Kigali, Rwanda 24 June 2011.

Interview Emmanuel Nshimyimana. Interview by Sara E. Brown. Murambi, Rwanda, 29 June 2011.

Interview G 3 “Lucy.” Interview by Sara E. Brown. Muhanga, Rwanda, 30 June 2011. Interview G 4 "Jennifer." Interview by Sara E. Brown. Muhanga, Rwanda, 30 June 2011. Interview G 9 "Lynn.” Interview by Sara E. Brown. Ngoma, Rwanda, 14 February 2014.

Interview G 12 "Kristen." Interview by Sara. E. Brown. Ngororero, Rwanda, 21 February 2014.

Interview G 14 “Kathleen.” Interview by Sara E. Brown. Ngororero, Rwanda, 21 February 2014.

Interview G 17 "Deena.” Interview by Sara E. Brown. Jali, Rwanda, 16 February 2014.

Interview G 18 "Cindy.” Interview by Sara E. Brown. Jali, Rwanda, 16 February 2014.

Interview Omar Ndiyeze and Richard Rugira. Interview by Sara E. Brown. Kigali, Rwanda, 15 June 2011.

Interview R 5 “Janet.” Interview by Sara E. Brown. Kibuye, Rwanda, 20 February 2014.

Interview R 6 Josephine Dusabimana. Interview by Sara E. Brown. Kibuye, Rwanda, 20 February 2014.

Interview R 15 "Rosanne." Interview by Sara E. Brown. Kanombe, Rwanda, 29 April 2014.

Interview S 5 "Nathan.” Interview by Sara E. Brown. Kigali, Rwanda, 12 February 2014. Interview S 7 "Rachel." Interview by Sara E. Brown. Kigali, Rwanda, 5 March 2014.

Interview Valerie Bemeriki. Interview by Sara E. Brown. Kigali, Rwanda, 26 March 2014.

Lemarchand, René. The Dynamics of Violence in Central Africa (Philadelphia: University of Pennsylvania Press, 2009).

MacKinnon, Catherine A. Are Women Human? And Other International Dialogues (Cambridge: The Belknap Press of Harvard University Press, 2006).

Mamdani, Mahmood. When Victims Become Killers: Colonialism, Nativism, and the Rwandan Genocide (Princeton: Princeton University Press, 2001).

Monasebian, Simone. "The Pre-Genocide Case Against Radio-Télévision Libre des Mille Collines." In The Media and the Rwanda Genocide, edited by Allan Thompson, 308-29 (London: Pluto Press, 2007).

Nowrojee, Binaifer. "Shattered Lives: Sexual Violence during the Rwandan Genocide and its Aftermath." Human Rights Watch (September 1996).

Oliner, Samuel P., and Pearl M. Oliner. The Altruistic Personality: Rescuers of Jews in Nazi Europe: What Led Ordinary Men and Women to Risk Their Lives on Behalf of Others? (New York: The Free Press, 1988).

Sharlach, Lisa. "Gender and Genocide in Rwanda: Women as Agents and Objects of Genocide." Journal of Genocide Research 1, no. 3 (1999): 387-99.

Staub, Ervin. Overcoming Evil: Genocide, Violent Conflict, and Terrorism (New York: Oxford University Press, 2011). 


\section{Mobilization and Militarization}

United Nations Entity for Gender Equality and the Empowerment of Women. "Concepts and Definitions" (2001.) www.un.org/womenwatch/osagi/conceptsandefinitions.htm.

Waller, James. Becoming Evil: How Ordinary People Commit Genocide and Mass Killing. 2nd ed. (New York: Oxford University Press, 2011).

Yuval Davis, Nira. "Intersectionality and Feminist Politics." European Journal of Women's Studies 13, no. 3 (2006): 193-209. 


\section{Rescuers}

As a Hutu, Elana was safe from the murderous Interahamwe militias who were hunting down and massacring the Tutsis in her village in the eastern province of Rwanda. As a woman, she was ignored by these majority-men gangs of perpetrators who made their rounds every morning, recruiting able-bodied sons and husbands to participate in the genocide. Elana could have spent those months at home and on her farm, tending to her family and her crops, essentially removed from, but not heedless of, the genocide taking place outside of her compound. She could have chosen to be a bystander.

Instead, Elana decided to venture to a neighboring hill and check on her friend, a Tutsi woman named Amanda. Upon arrival, Elana found Amanda and her five children inside the house, huddled around her badly beaten husband. As she stood in the doorway and assessed the situation, two Interahamwe militia men ran up the hill. They forced their way past Elana into the home and dragged Amanda's husband out to the garden to interrogate him. Realizing that once the killers had finished with the husband, they might come for Amanda and her children, Elana sprang into action, pleading with her friend to take her children and follow her down the hill to her home. But Amanda was in shock and refused to leave her husband's side, even when Elana grabbed the children and fled.

Amanda eventually made her way to Elana's home, but only after she saw her husband murdered. Together, the women devised a plan to rescue Amanda and her children. Elana's husband returned home to find the household doubled in size and his wife determined. "We are going to stay the way we are, we are not going to give them out. They are going to stay with us, and if they decide to kill them, then they'll kill all of us altogether." After several harrowing months, the RPF liberated their village. Elana, Amanda, and their families survived the genocide.

Many women rescuers vividly recalled the rhetoric found in print, on the radio, and expressed in the marketplace leading up to and during the genocide. These women were not swayed, however. Rather than follow the orders of the genocidal government, some women participated in acts of "selfless" rescue, or rescue acts undertaken without thought of financial gain. ${ }^{2}$ These women rescuers showed bravery and a tenacity against societal pressures and constructs that sanctioned violence. Women rescuers also displayed a sense of individualism 
and independent thought. Their rescue initiatives required direct action. If violence falls into direct and indirect acts, no such distinction exists in rescue. ${ }^{3}$ And gender matters. As a number of scholars have shown, most rescuers during the Holocaust were women. ${ }^{4}$ Sociologist Emile Durkheim asserted that altruism, selfless giving, is the fundamental basis of social life $\mathrm{e}^{5}$ and "wherever there are societies, there is altruism." And while the measures taken by women rescuers in Rwanda include a range of actions that incurred a broad spectrum of risk, ${ }^{7}$ the steps taken often meant the difference between death and survival for the women's charges. ${ }^{8}$ In many instances, minor acts of rescue, including providing food or water to a Tutsi or tending to a wound, were as significant to survivors as major acts, like providing shelter for a night or more. For example, Charles, a survivor, recalled an occasion when a Hutu woman generously purchased food from an Interahamwe militia man in order to feed him and others hiding at a local dispensary. While the gesture was minimal and incurred little risk on the part of his benefactor, that food sufficed for several days. Rachel, six years old during the genocide, credited her survival in one instance to food and water given to her by an elderly Hutu woman. Even though this woman at first refused to provide her with shelter and left her and another woman wounded in a field for several days before relenting and bringing them to nearby RPF forces, Rachel viewed her limited actions in supplying sustenance as lifesaving. ${ }^{9}$

Feminist scholar Cynthia Enloe explains that we need to recover not only the "angelic self" but the "complicated self" as well. ${ }^{10}$ Women rescuers could easily be summarized as angelic and there the discussion would end. But if we are to learn anything from their behavior, we must avoid a patriarchal construct that strips them of their humanity and instead plumb the complexity of their choices during the genocide. Their complicated stories include their motivations for rescue, the risks they undertook, their successes, and their failed attempts to save lives. The humanity embedded in their choices is brought into sharp focus and contributes to a broader understanding of women rescuers and of rescue during genocide, wherever enacted. Often, rescue hinged on a convergence of external factors. Debórah Dwork and fellow historian Robert Jan van Pelt have noted that during the Holocaust "clandestine rescue depended upon luck, fortuitous circumstance, and links." "11 This holds true during the genocide in Rwanda as well: rescue depended upon chance encounters, good fortune, or unlikely situations. Failed attempts were frequent, and even in instances of success, tragedy necessitated the very act of rescue.

Women rescuers are difficult to locate for a number of reasons. First, there is no nationwide mechanism for recognizing and verifying instances of rescue that is comparable to the Gacaca courts information about perpetrators. ${ }^{12}$ Identifying women perpetrators and verifying their testimonies through review of their Gacaca transcripts is a relatively straightforward process (though not without its challenges). Rescuers, by contrast, are difficult to find, require a separate verification process, and live throughout the country, often in remote rural regions far from a main road. This has contributed to a skew in existing scholarship and has shaped the narrative of the genocide in Rwanda. Then too, despite Rwanda's post-genocide stability, some women continue to remain silent about their rescue 
activities for fear of retribution or alienation from Hutu neighbors. ${ }^{13}$ It is thus difficult to determine precisely how many women were rescuers. Many remain unrecognized by society and undocumented by scholarship.

\section{Risks of rescue}

Rescue carried dangerous consequences for those who dared to defy the extremists. As one woman rescuer, Joan, explained, "if they found out that you are hiding [Tutsis], that was well known - you would die with them. That was obvious." 14 Describing their acts of rescue as voluntary, the women knew the risks they braved. And their testimonies, detailing their thoughts and feelings during the genocide, indicate a deliberate and calculated decision-making process that resulted in rescue.

Women rescuers were not impervious to the extremist-controlled fear campaign described by women perpetrators. They were equally terrified and referred to the fear, violence, chaos, and desire to flee that women perpetrators experienced just before and during the genocide. The difference between the two groups lies in how each group reacted to these trepidations. Emereth described the atmosphere just after President Habyarimana's plane was shot down.

When we heard about the plane crash, we stayed indoors the following morning. They announced on the radio that people had to stay inside their homes. They said, "Avoid being in groups of more than two people. We do not want to see three people or more together." We stayed home the whole day, scared to be near anyone or even talk to anyone because it had just been forbidden for people to be in a group. ${ }^{15}$

When asked if they were afraid during the genocide, Wendy and her daughter, rescuers of a Tutsi family, said they were. Wendy's daughter explained, "We had concluded that whatever would happen to them [the Tutsi family hiding in their home], it would happen to all of us. It would have an effect on us but of course, we were afraid." ${ }^{16}$ Golda held a similar conviction.

I was ready to die with them. I was so scared.... I saw so many people who had given up on them [the Tutsis], they would give them in and they would kill them. I would never have accepted - I was ready to die with them. ${ }^{17}$

Another woman, Elana, was able to master her fear.

At some point, I realized that fear is not the solution, got over it, and was like, "Whatever happens will happen, but as long as I have a right to move freely, I'm going to do what I can to save whom I can." After seeing the kind of killings that were happening, I wasn't afraid anymore. I would stand and protect those that I have in the house. ${ }^{18}$

As Elana spoke, she changed tenses. The past became present for her. 


\section{Rescuers}

Ruth opened her doors to a prominent local man and hid him in a space just behind the main house in her compound. She gave him a blanket to keep him warm and to protect him from the rain. One sunny day, he ventured from his hiding place to hang out the blanket to dry. Roaming Interahamwe spotted him, let out a cry, and entered Ruth's compound. Ruth was alarmed at their arrival but the Interahamwe had come to her home before, demanding bribes in exchange for the lives of two girls she was hiding. Then, the risk had been great to be sure but, ultimately, no one had died. But this time it was different. The Interahamwe captured the man and brought him from his hiding place to the front of the compound where they held Ruth. With the children looking on, they killed the man where he stood. Then, they turned on her. "They beat me, they took me and undressed me. They were going to kill me." In the end, one of the Interahamwe stopped them, insisting that they cease on account of Ruth's husband. "If this man, the husband of this wife, finds that you've killed his wife, I'm telling you, this war will never end." 19 The absence of Ruth's husband, the recognized head of the household, may have saved her life. As Rwandan patriarchal society positioned wives as subsidiary dependents of their husbands, members of the Interahamwe were hesitant to take further action against Ruth without first questioning her husband. He was away at that time of their visit and therefore unable to represent his wife or speak for her actions. In fact, he was secretly assisting his brother in a separate act of rescue. Still, the Interahamwe hesitated and did not kill Ruth for fear of his violent reprisal.

The Interahamwe then turned their attention to the girls hidden in Ruth's home, forcing Ruth to act quickly. Shaken and badly hurt, she regained control of her faculties in time to stop the Interahamwe from murdering them. Though she faced near certain death if found out, Ruth lied to the Interahamwe and insisted that the girls were her sisters. ${ }^{20}$ She relied on the chance that the militia who stood before her had never visited her home before and were therefore unaware of the true identities of the girls. It is unclear if the murderers believed her, but they left without harming them further. Ruth's experience illustrates the convergence of luck and fortuitous circumstance with mixed results. Though illfated timing had resulted in the death of her charge, Ruth remained alive thanks to the fortuitous absence of her husband, and her quick thinking enabled her to save the two girls from death.

Martha and her husband embarked readily on rescue actions while their neighbors, both the husband and the wife, participated enthusiastically in the genocide. Because of their proximity to Martha's family compound and the previously intimate connection between the families, they soon realized that Martha and her husband were hiding a Tutsi infant in their home. When some Tutsi neighbors, all close friends, appeared on Martha's doorstep late one night, she and her husband did not hesitate to welcome them. One woman admitted to Martha, "Look, I have a kid, I don't know how we are going to stay here with the kid." ${ }^{21}$ Martha assured her, "I also have a kid," and brought them into the compound. ${ }^{22}$

Unfortunately, the infant's cries alerted Martha's extremist neighbors. The wife confronted Martha and demanded that she hand over the child to be killed. 
Martha could have complied, as her neighbor's husband was affiliated with the Interahamwe and very dangerous. She could have even reasoned that in giving up the one infant, she might protect the other Tutsis in her care. But she stood her ground, aware that the consequences of her actions could result in death. She tried to reason with the woman, relying upon their shared experience of motherhood to persuade her. "So I told her, 'You are also a mother like me - if you want to kill this kid then you have to start with mine and then you can kill the other persons." "Her neighbor was not swayed by Martha's appeal to her maternity nor was she deterred by her expression of solidarity. Instead, she marked Martha for death. " 'No, what I'll do is I am going to tell my husband, and we shall come and kill you." "23 She went to her husband and told him that Martha and her husband were hiding Tutsis.

Martha's loyalty to her Tutsi neighbors confounded them. Unable to comprehend her maternal motivation to rescue a child, they surmised that Martha was secretly a Tutsi and publicly announced their intention to spare Martha's Hutu husband but to kill Martha and the Tutsi infant in her compound. It is unclear what they intended to do to her children. Again, Martha refused to give up the infant in her care or any of her other charges. She also refused to send them away or flee. Instead, she waited in fear for the day when the Interahamwe would attack. But fortuitous timing saved her life; the RPF forces arrived first and secured the area, effectively ending the killings.

Julian was a widow living at home with her children and grandchildren when the genocide began. One night, five women and children from the area came to her and asked that she hide them. She took them in, gave the children water and the women beer, and fed them. Unfortunately, the arrival of the women and children to Julian's compound did not go unnoticed by her neighbors. That same evening, people gathered outside her compound with torches and weapons and demanded she give up the Tutsis in her home. Julian bravely refused to allow them to enter.

They wanted to kill them. They said, "We hear people," and I said, "There are only my children," because I had my children and my grandchildren. I made all the children sleep together, none slept apart. They came and asked, "Let us look inside." I said, "Don't wake up my children, let them sleep. You will see them in the morning." 24

Insisting that she was neither a witch nor a robber (in Rwanda, both legitimate reasons to bring the mob to her compound), and again asserting that the people she harbored were her kin, she persuaded the crowd to disperse and leave her until the morning. She knew that if they were caught hiding Tutsis, she and her family would be harmed. Julian employed several layers of strategy. First, she refused the mob entry, insisting they leave her and her family in peace. Her assertiveness belied any fear she felt and the outward display of confidence made the mob hesitate. Second, she placed all of the children together in one room and arranged it to appear as though they regularly bunked together. Had the mob 


\section{Rescuers}

overwhelmed her and entered the home, they would have been hard pressed to determine who belonged and who did not. Third, she strategized ways to protect her charges from future discovery.

Julian stayed awake all night with her children, fearful of what the dawn would bring. But rather than give up the people in her care or send them away, she and her children capitalized on the darkness and spent the hours hiding everyone in the rafters just under the roof, in the urwina or banana beer pit, and in the bush outside her home. When morning came, they carefully set the stage. They sat before the house in the compound, in the open and seemingly unafraid, and pretended as though nothing were amiss. The Interahamwe returned again and again, once accompanied by the local leader, Conseilleur Gashumba, in search of the people she hid, but they found no one thanks to her clever hiding tactics and the timing of their visits. Had they visited at night or at a time when Julian was assisting the people she was hiding, perhaps their efforts would have met a different end. Instead, when they arrived, they found Julian and her family attending to daily chores and "normal" household activities. There were no Tutsis in sight. While her family faced great risks, Julian refused to be intimidated, bought, or coerced into giving away her charges. Her resilience and bravery set the tone for her children and they too refused to give in to their neighbors or local leaders. Though she developed a reputation for rescuing Tutsis, ${ }^{25}$ these rumors could not be confirmed by any outward expression of fear or betrayal by her and her family, and the people she hid were never discovered. "Nothing happened to them, all of the children are still there; three of them are with me and they are fine." 26

If some women rescued other people's children, others had the opportunity to rescue their own. Margaret knowingly endangered herself in order to stand alongside her family. As the genocide spread throughout their region in southwest Rwanda, Margaret's Tutsi husband and in-laws encouraged her to flee and save herself. As a Hutu, she was protected from the gathering Interahamwe and could find safety among her Hutu kin. Although she would probably face hostility for having married a Tutsi man, the odds were good that she would survive. However, she would have to flee alone. Primacy of paternal ethnic identity meant that her three children were considered Tutsi as well. She refused to leave. "Because I had a little baby, I had given birth in the month of March, I saw I couldn't leave my kids behind and my husband so I decided to stay." ${ }^{27}$ Margaret chose to flee with her family and tens of thousands of others to a nearby technical school located atop a large hill (now famously referred to as "Murambi" and the site of a genocide memorial), and prayed they would be safe. Late one night, soon after they had arrived, whistles sounded an attack. Margaret huddled in the corner of a small brick classroom with her family around her as Interahamwe, FAR soldiers, and civilian volunteers hurled stones and spears through the barred windows. Her husband pushed her from the room in an attempt to save her life, shouting, "Don't kill your sister!" 28 Interahamwe quickly surrounded her and examined her identity card to confirm that she was a Hutu. Chaos ensued. Eventually, persuaded that she was a Hutu, they agreed to spare her life. But then they 
pointed to the infant secured to her back with a kitenge, a decorated cloth, and demanded she give up her baby girl.

Margaret knew her choices: she could hand over her daughter and live, or protect her child and lose her protective status as a Hutu. Her predicament is best captured by literary scholar Lawrence L. Langer's formulation of "choiceless choices" during the Holocaust. During genocide, normal decision-making parameters are upended and the notion of "freedom" and "choice" are misnomers used to describe impossible circumstances. And so Margaret was given a "choice" between two options: save herself by giving up her infant to die, or refuse and face death along with her child. Langer writes about choiceless choices during the Holocaust, "The alternatives are not difficult, they are imposs$i b l e$, and we are left with the revelation of a terrifying question posed by a universe that lacks a vision to contain it." ${ }^{29}$

Margaret decided between the two evils and refused to hand over her daughter and save herself. For that reason, she is a rescuer. And because she made the decision to rescue her infant, she was treated as if she were a Tutsi, similar to the experience of Martha mentioned above, and faced certain death. Still, she did not waver. Margaret kneeled before their raised machetes and asked for a moment to pray. One man from the mob spoke up and ordered the others to "let her finish." Her prayers moved him and just before the machetes fell, he stepped forward "and told the whole group "whoever dares to put a machete on this woman, I will finish them myself." "'30 A whistle blow called the killers away before anyone could challenge the man's declaration. Today, Margaret and her daughter are two of the 14 known survivors of that massacre. Her husband and two sons perished.

As both a rescuer and a survivor of the genocide, Margaret suffers from the duality of her identity and does not wholly belong with any group. Her status as a survivor is vigorously contested by some, including one of the governmentappointed tour guides stationed at Murambi in early 2014 who explained that, because Margaret was a Hutu, she could not be counted among the survivors of a genocide that targeted Tutsis. This exclusionary assertion ignores the fact that her act of rescue cost her the protective status as a Hutu as she "became" a Tutsi in the eyes of the perpetrators. As such, she was targeted for death. In addition, this assertion, problematic most especially for its ethnicism, overlooks the fact that Margaret's social status derived from her Tutsi husband and was elevated by mothering children, all of whom were considered Tutsi. ${ }^{31}$

Similar to Margaret's decision to stand in solidarity with her husband and children, while many women made the deliberate choice to be bystanders to the genocide, Matilde chose to reject this path and rescue instead. One day during the genocide, Matilde went to her neighbors' home to borrow their jerry can to fetch water. They were not at home. As she crossed the road on her way back to her compound, she met several men from the night watch who were frightened by the cries of an infant coming from the bush nearby. They refused to accompany Matilde, and so she went alone and found a several-months-old baby girl wrapped up and lying alone. Matilde could have walked away from the crying infant. She did not know the child and was not bound to her. Indeed, she sur- 


\section{Rescuers}

mised that the girl had been placed there by one of the Tutsis who had fled to the region from Nyaruguru only to be murdered upon arrival. No one would have cared if she had left the child to die in the bush. Rather, given the context of genocide, they would have encouraged the child be left in the wild or killed. But Matilde was moved by the sight of the infant, wrapped in cloth and covered with bugs. She viewed her as "human like my children" and gathered her up. ${ }^{32}$

Fearful that the men would kill the infant if they found her, Matilde avoided them and took an alternate route back to her home. Though she and her husband realized the risks inherent to rescue, they were not deterred. Perhaps the fact that they had Tutsi kin and were opposed to the genocide spurred them to act. But the gender norms of the time put the bulk of the rescue responsibilities on Matilde; as a wife and mother in rural Rwanda in 1994, she was responsible for the care of infants and small children. Culturally forbidden to ask her husband to assist her, she recruited their older children to help instead. The Interahamwe arrived at their home soon after her, informed by the men that she had entered the bush in search of a child, but they mistakenly looked for an older child. Matilde hid the infant in plain sight alongside her infant twins and small children, named her Rose, and breastfed her as one of her own. The Interahamwe did not notice that there were three infants instead of two; they ignored the children much like they ignored Matilde. But Matilde feared her luck would run out and they would catch on. So she began hiding Rose in the bush near her home. But Rose was never alone; one of Matilde's older children stood guard nearby. Eventually, she fled with her children and found refuge at her mother's home until the genocide ended. ${ }^{33}$

Women did not rescue out of ignorance. The risks that accompanied rescue were known to all; the extremist propaganda machine ensured they were repeated by radio personalities, print publications, and local leaders. The ramifications of rescue were discussed in fields, bars, marketplaces, and churches throughout Rwanda. Still, women rescuers were not deterred, even when faced with immediate and direct threat of death. They relied on a combination of luck, fortuitous circumstances and timing, ${ }^{34}$ and the links that occasionally transcended ethnic divisions in Rwanda. Though these women were by and large successful, they often suffered greatly as a result of their actions. Ruth watched as the Interahamwe murdered one of her charges and was beaten for harboring a Tutsi. Martha kept the Tutsis in her home even though her neighbors had marked her for death; timing saved her life. Julian plotted ways to conceal those she hid rather than give them up to the mob outside, relying on her own boldness and a good measure of luck to save them. Margaret refused the safety her ethnicity afforded her in order to protect her infant and was saved by a whistle, calling her would-be murderers away. In each of these instances, the women who took action were aware that their lives were at risk but nevertheless acted with the intent to save themselves, their family members, and the people they were rescuing. Rooted in the catastrophe of genocide, these remain the success stories and offer brief moments of hope and triumph in an otherwise tragic narrative.

Women rescuers experienced additional vulnerability because of their decision to rescue; their acts carried the added risk of violent reprisals and possible 
death. And some rescuers capitulated, giving up their charges to the Interahamwe and military. But the 16 women rescuers interviewed refused to give in despite pressure from their neighbors, the media, their local leaders, and the government, as well as the threat of a fate similar to that of the Tutsis in the event that they were caught. As we will discuss in Chapter 6, "Post-Genocide Trajectories," many continue to fear for their lives today.

\section{Failed efforts}

A number of women attempted to rescue but were unsuccessful. When the genocide reached the western region of Rwanda, Beth, a Tutsi woman married to a Hutu man, became both a rescuer and a survivor. Her marriage to a Hutu man afforded her a certain degree of protection through her husband's ethnicity and because of his status as a man in Rwandan society. Were their ethnic identities reversed, she would have been powerless to rescue him. Despite the risk of death that both faced, they began to rescue friends and family members within their compound. Word got out and someone informed the Interahamwe of their actions. They marched Beth, her husband, five children, and sister to a building near the town market. There, they imprisoned her and her children, killed her sister, and took her husband to another location where he was also killed for his acts of rescue. The people who had hidden in their home were massacred. ${ }^{35}$

Only Beth and her children were spared. First, the Interahamwe did not realize she was Tutsi. They assumed she was a Hutu and did not bother to verify this assumption. Second, the Interahamwe underestimated her. Because she was a woman, they did not view her as a decision maker in the home and therefore overlooked her complicity in the attempted acts of rescue. They saw her instead as a subordinate following her husband's orders, without agency and without a voice in household matters. As a result, though they had just made her a widow, they offered to help her, asking, "Where are you going now?" Beth considered her options.

I was thinking of hiding with the kids, there was a farm close by and I was like, "I can't hide with these kids - they are very young." Because I gave birth every year, they were still very young. I thought of killing myself first but I was like, "That's not possible. Should I first kill the kids? Throw ourselves in [Lake] Kivu?" ... I just didn't know what to do at that moment. So I told the two guys, "Ok, just escort me to this friend of ours."

The Interahamwe then accompanied her to the home of an influential Hutu man, a friend of her late husband, who agreed to hide her and her children. Because she no longer benefitted from the protection of her Hutu husband, she was especially vulnerable. This vulnerability was further compounded by the hostility of her in-laws; her husband's sister attempted to locate and murder her on several occasions. In the end, Beth and her children survived the genocide, but at great cost. The friends and family she and her husband had harbored in their 
compound were murdered along with her husband and sister. There are no survivors who can credit her with their survival and so she cannot find comfort in the knowledge anyone survived as a result of her efforts. Instead, she lives with the memory of their failed rescue attempt and its violent repercussions.

Other women remain haunted by their inability to rescue during the genocide. Rachel was just six years old when the genocide reached her hill. The second youngest of 12 children, she is one of two who survived. Her family and many other Tutsis fled to a nearby mountain when the genocide began, hiding together in the bush. She recalled the arrival at the base of the mountain of truckloads of Interahamwe and soldiers armed with machetes, clubs, spears, and guns. Once gathered, they attacked, massacring those in hiding as the remaining fled in the chaos. When they reached her family's hiding place, she fled to the home of an elderly neighbor with her three-year-old brother Emmanuel ("Emy") tied to her back. From then on, though she was a child herself and unable to exercise fully autonomous agency, he was her charge. ${ }^{37}$

While the neighbor knew the children and was well acquainted with their family, the older woman initially refused to hide them, chasing them away, but soon changed her mind. Perhaps the link between their families was strong enough to persuade her. Perhaps she felt some moral or religious-based compunction. It is not clear what prompted her, but when the Interahamwe passed by her home soon after, she hid the children in the pit latrine in the back, calling them out after the killers had passed.

Although she agreed to hide Rachel and her brother, the older woman was active with the Interahamwe, often accompanying her sons, members of the killing militia, as they hunted Tutsis. She was also fickle. After three days, her motivation to rescue had vanished, and she chased the child fugitives from her compound. Rachel, with Emmanuel to her back, made her way to the high grasses along Lake Kivu. There, she allowed herself a brief rest and set Emmanuel down, hidden among the grass, thinking he would be safe. When the Interahamwe attacked shortly thereafter, they happened upon the boy and cut him on the head with a machete. Not realizing Rachel was nearby, they left him for dead. Rachel gathered Emmanuel up and fled back to the old woman's compound, begging her for assistance. Eventually, she took them back in after her sons, the very same who were members of the Interahamwe, persuaded her that it would be worse for the children to die in her banana plantation. Little Rachel tended to Emmanuel but his wound became infected and infested with maggots. Fearful that his cries would alert her neighbors, the older woman turned them away for good, and a starving and weak Rachel once again tied Emmanuel to her back and returned to the grassy shores of Lake Kivu. It was impossible to hide his cries and Rachel was weak from hunger. Rachel made a decision that no sixyear-old should ever have to make.

So I left. What happened is that Emy continued to be in so much pain and the wound had started rotting, he was in so much pain, he was crying all the time, and people had started noticing. So what I did is that I tried to leave 
him for the first time. And I came back. He continued crying and crying and crying but I didn't have anything to do! I couldn't carry him because I had spent a couple of days without eating, so I wasn't strong enough to carry him with me. So I left him behind and fled. ${ }^{38}$

At this point in the interview, Rachel broke down. Despite her best efforts, she was unable to save her brother. For the past 21 years, she has blamed herself for Emmanuel's death. She remains haunted by the fact that she could not find a way to save him. ${ }^{39}$

\section{Significance of local knowledge}

Women did not have a broad understanding of the national dynamic and the nuanced social and political underpinnings of the genocide. Rather, they typically displayed extensive knowledge about local individual actors, actions, and their impact in the immediate community. This local knowledge, combined with their understanding of their place in the existing social and patriarchal structures, shaped the way many women rescuers navigated through the prevailing violence.

Josephine Dusabimana is a well-known rescuer from Kibuye who was honored by the U.S. Department of State in 2011, and is the only woman rescuer who requested that I use her real name and not a pseudonym. In an effort to rescue those targeted for murder, she fearlessly outmaneuvered both the perpetrators of the genocide as well as her own family on several occasions. In one instance, realizing she could no longer hide two Tutsis in her home, she asked her cousin, who owned a boat, to transport two of her charges across Lake Kivu to the Democratic Republic of the Congo (DRC). Her cousin demanded compensation. She considered her options and offered him ownership of a small herd of goats he was currently tending on her behalf. She knew this was a risky move. If her husband found out she had sold their goats in order to save these two people, he would be furious and possibly give them up to the Interahamwe. So she kept it a secret from him. But she also realized that she could not trust her cousin since his only incentive to assist her was financial gain. "All of a sudden, something hit me and I was like, 'The way this person accepted to help me when they are taking them across the lake - will they merely throw them in the lake?" ",40 Again, she considered her options. "I got one of them [the Tutsis she was hiding] who was called Paul and told him 'Let's go outside.' So when I took Paul outside to talk to him, I told him, 'Now, you are going to go. But how will I know that you reached where you are supposed to go?" ${ }^{41}$ In the end, Josephine and Paul agreed that he would hand over a marble he carried in his pocket to her cousin upon arrival in the DRC with instructions to deliver the marble to Josephine. When Josephine received the marble the next day, she knew they had arrived safely.

In addition to being a quick thinker, Josephine was also very courageous. In another instance, realizing that her husband's patience was again growing thin 
with the number of people she was hiding in their home, Josephine became despondent.

Well, after all that I went out behind the house, sat, confused, tired, didn't know what to do, and hadn't eaten anything, I decided to get a bucket to go and fetch water. Not because I was supposed to fetch water but just to think. So I went to fetch water and when I was there, I saw this metallic boat [belonging to] some guy. I went closer to it. And I looked at it and I was like, "How will I even start this boat?"42

In a matter of moments, Josephine devised a plan to spirit her charges across the lake to the DRC.

I fetched the water, put it on my head, and headed home. But I was on my way, I was thinking about that boat, that metallic boat. It was all locked up with a big padlock. I went home thinking about that boat and when I reached home, my husband was like, "What are you thinking?" and I was like, "Nothing." 43

She decided to steal the boat, which belonged to Kanyenzi, a prominent businessman who owned the local Bralirwa distillery and was a member of the Interahamwe. Her plan required planning, luck, and bravery. The boat was docked on Lake Kivu. Josephine calculated that a mother and two children bathing at the lake in broad daylight would not arouse the suspicions of the Interahamwe or nearby guards, so she brought her two boys to serve as a distraction for the guards while she cut through the lock securing the boat. As she worked, she encouraged her children to swim, play, splash, and make a commotion. Her ruse worked; the guards ignored them. As their splashes and shouts masked the sound of the bolt cutters, Josephine freed the boat but arranged the lock to appear intact. She made her way home with the children and hoped no one would discover the broken lock.

Later that evening, she returned to the lake and, under cover of darkness, she took the boat to transport more Tutsis across the lake to the DRC. ${ }^{44}$ Though the boat was reported stolen, there were no witnesses that night to pinpoint Josephine. Asked if Kanyenzi ever discovered that it was she who had taken his boat, she burst out laughing. "He found out about it during Gacaca!" 45 It is no surprise that Josephine's husband referred to her as sibikangwa or "one who is not a coward." Freeing the boat in broad daylight before armed guards and returning at night to steal it required a great deal of courage (and a measure of luck). ${ }^{46}$

Josephine was not alone in her utilization of local knowledge and her bravery. Jane, a child survivor of the genocide, recalled the efforts of a nun who helped to harbor her family and hundreds of other refugees at the St. Famille church in Kigali. When Jane, just two years old at the time, was severely burned by boiling tea, the nun drove her and her mother through multiple Interahamwe checkpoints to seek treatment at a hospital. Before they left, the nun had turned to Jane's 
mother and said, "Hide your ID cards - maybe by chance they won't recognize you. So you go and if they ask for your ID card, just tell them you lost it." 47 Thus the nun pleaded their case at each checkpoint, arguing that Jane would die if she did not receive medical treatment and, without proof that Jane and her mother were Tutsis, they should be given leave to pass. This worked time and again and they made it to the hospital where Jane received treatment for her burns. The nun risked her life in order to bring Jane to the hospital. She was clearly aware of what would transpire at the checkpoints and took steps to mitigate the risk, warning them to abandon their ID cards. Then, at every checkpoint on the way to and from the hospital, she advocated on behalf of Jane and her mother and did not lose her nerve or give them up to the suspicious Interahamwe. Without this one woman's intervention and bravery, Jane would surely have died. ${ }^{48}$

Other women relied not only on local knowledge but also on local ignorance of events on nearby hills. Joan, an older woman with steely gray streaks in her hair, hid five Tutsis in her home. They arrived in intervals. The first two people came to her on a Monday in search of refuge; another two joined them on Wednesday; and the last arrived on Friday. For the next week, Joan hid four of the people in plain sight, claiming they were visiting members of her extended family. She was able to do this because they were from an adjoining hill and therefore unknown to her neighbors; she could pass them off as family relations to the local Interahamwe when they twice searched her compound. ${ }^{49}$

The first time the Interahamwe arrived, they demanded to see the people she was hiding. She showed them to the living room where everyone was seated and said, "Well, the people who are here, they are our relatives." ${ }^{50}$ She explained that the violence on her "relatives" " hill had escalated to the point that it was unsafe for them to return. Seeing everyone seated out in the open without fear, the Interahamwe accepted her explanation and left. The second time they searched the home, they found the same people and left, believing they were family. Joan relied upon the hill-centered knowledge of the Interahamwe killers. Because the fifth person Joan was hiding was from her hill and thus known in the area, she hid him with the goats in the hope that the Interahamwe would overlook that shed, which they did.

Sometimes local knowledge included the supernatural. Sula Karuhimbi, ${ }^{51}$ an elderly and fiery Muslim woman, was known in her area for having a relationship with Nyabingi, ${ }^{52}$ the traditional female spirit that accompanied her and afforded her protection and witch-like powers. In Rwanda, Islam did not make much headway as the pre-colonial monarchy did not permit Muslim slave traders entry into the kingdom. As a result, conversion to Islam came later and lagged behind Christianity, with less than 5 percent of the population claiming Islam as their faith (at the time of writing). In Rwanda, conversion to monotheistic faiths such as Christianity and Islam often did not result in a rejection of prior belief systems and practices but in an intertwining of them. As a result, though the majority of Rwandans identify as Christian, Nyabingi is still feared and respected in Rwanda and often credited for inexplicable deaths and illness. People like Sula who are believed to have a connection to Nyabingi are feared as well. Sula, 


\section{Rescuers}

confident that Nyabingi and supernatural powers would protect her, leveraged this traditional fear of her and Nyabingi to rescue dozens of Tutsis who found refuge in her compound.

Sula was horrified when the genocide began. It reminded her of the ethnic violence that accompanied the independence period in Rwanda when she was a young woman. "Since I was a child they were burning Tutsi belongings, chasing them away and now it has happened again?"53 She decided to take action, gathering Tutsis to her home and hiding them in her compound. She mixed "traditional medicine" and smeared some with potions in order to protect them, tying the younger girls to her kitenge in order to ensure they would not be attacked when she went to fetch water. She threatened the Interahamwe with fire and animal attacks should they approach her home. "I said that the Nyabingi would eat them!" Initially, men were not cowed. "They asked 'do you work with witch doctors?" Sula replied, "I have my Nyabingi, let me come." 54 She got up and approached them, making noises and shaking her bracelets the entire time. The men ran from her in fear. When the Presidential Guard set up a roadblock outside of her home in the hope of catching Tutsis in her area, she set fire to the roadblock. When she approached them on her way to run errands, she whistled and made noises and they fled from her. The military and accompanying Interahamwe were terrified of her and her Nyabingi, and left her and her charges unmolested. Some even came to her to ask for medicine and treatments. Sula leveraged her status and local superstitions and beliefs in order to protect her charges. When the RPF soldiers arrived in her area, they asked her why she didn't flee before them. She retorted "I am also Inkotanyi [a slang term for a member of the RPF]. There is no one more Inkotanyi than me!" 55

\section{Gender norms and rescue}

In certain instances, sexism saved lives. For some women rescuers, the fact that they were women played a significant role in their success. The Interahamwe killing militias regularly recruited "ordinary men" to perpetrate genocide. As explained by political scientist Scott Straus, these men were representative of the "demographic profile of adult Hutu men at the time of the genocide ... with average levels of education and who had no prior history of violence." While many participated voluntarily, those reticent to join the Interahamwe were driven by coercion, social pressure, fear, and the promise of economic incentives to comply. ${ }^{56}$ On occasion women were recruited, but most were excluded from this genocidal extension of umuganda, mandatory voluntary labor that was instituted by Rwanda's pre-colonial monarchy and modified to fit the needs of colonialists and, later, those of the government. ${ }^{57}$

This had a multi-fold effect on Rwandan women, especially those living apart from or without a husband in the home. ${ }^{58}$ First, it meant that their homes were exempt from the sometimes daily visits from Interahamwe in search of recruits or those who were hiding to avoid participation. Then too, they did not have to struggle with the daily ideological indoctrination promulgated by the 
Interahamwe that pitted Hutus against Tutsis. In some instances, the gender bias that accompanied this exemption also blinded the Interahamwe to the agency exercised by women rescuers, thus the latter did not fall under suspicion. Women rescuers were able to take advantage of gender norms that emphasized a woman's passivity and meekness to their advantage or, at the very least, fly under the radar.

Both men and women participated in acts of rescue, hiding people in their homes, in their pit latrine, and in their gardens. But women often relied on gendered perceptions of the private domestic sphere, secreting their charges in spaces that men typically avoided. Nicole relied on this bias multiple times, anticipating that the Interahamwe would give her little notice and not bother to search her home. While this typically worked, in one instance the Interahamwe banged on the door and insisted upon entering her home to search for Tutsis. Nicole switched tactics and bluffed, brazenly inviting them in. "Please, make yourself at home, search the house." This shocked the Interahamwe. "So when I told them, 'Please, search the house,' they became scared of entering the house. They could see I was only a woman and they decided not to bother going into the house." ${ }^{59}$ Entering a woman's home without the presence of her husband (who had left her) was considered uncommon for men who are not kin and abrogated traditional Rwandan norms. The men grew embarrassed and declined to search the interior of her house, where they would have found a Tutsi child hiding under her bed. The child survived and is now grown. He visits Nicole and considers himself one of her children.

Other women hid people in areas of the house traditionally restricted to women. When Martha took in her neighbors, she hid them throughout her compound. The woman and a child were brought specifically to the kitchen, "because the men, they rarely went to the kitchen, they thought the kitchen was for babies, so they never checked most of the time the kitchen." ${ }^{60}$ Usually located in a small room in the back of a traditional compound, kitchens are separate from the main home. As cooking was within the purview of women's domestic responsibilities, men rarely entered the kitchen. Martha hid the mother and child until the RPF liberated her village. Gendered demarcations of and within the domestic sphere thus increased these women's chances of managing to rescue Tutsis during the genocide.

Women rescuers acted with the consent of their husbands or, as we have seen, in part because of the absence of a man in the home. It is quite possible that the absence of men in the home serves as a determining factor for how women were able to successfully rescue later. At the very least, it serves as an indicator of women's independence of thought, and their capacity to act outside the genocidal nature of 1994 mainstream society in particular and its patriarchal norms in general. Of the 16 women rescuers interviewed, just seven were accompanied by a husband or male partner at the onset of the genocide. Four were widowed, two were married but their husbands were away from the home, one was separated from her husband, one was too young to marry, and one left her family in the United States in order to assist her family in Rwanda. One woman was married 


\section{Rescuers}

at the onset of the genocide but was widowed during the genocide. She believed her husband's death was a direct result of their acts of rescue, but she continued to protect the Tutsi child they harbored in her home. Of the remaining seven women who were accompanied by a spouse, one woman was married to a Tutsi man who was later killed, and one defied her husband in order to protect the Tutsis in her care. As a result, just five of the 16 women interviewed were married and rescued in partnership with their husbands. The rest of the women acted of their own volition and without the influence of a male spouse who, according to Rwandan law and custom, would have served as the head of the household. They enjoyed a pre-existing level of independence and selfsufficiency, and were not subject (according to law and custom) to the authority of a man.

If a woman's husband objected to her acts of rescue, there was little she could do in opposition. Patty hid in a succession of homes during the genocide. One evening, she and another woman were taken in by a woman who gave them water for bathing and a change of clothes. In the morning, when that woman's husband arrived home after a night of killing with the local Interahamwe militia, he promptly threw out the other woman because her arm was injured. The husband agreed to keep Patty alive, but only because he wanted her as a house slave. ${ }^{61}$ This also worked in reverse: Beth found refuge in the home of a prominent Hutu man despite the angry opposition of the man's sister and mother. They both lived in his compound and despised Tutsis. Still, despite their threats and taunts, they could not harm Beth. The man was the head of the household and had the final say. ${ }^{6}$

Josephine remains one exception to this rule. She took great risks to rescue nine people, often in direct defiance of her husband or without his knowledge. One evening, a man and two young girls arrived on her doorstep in short succession, begging for a place to hide. She brought them inside without a second thought. Her husband was furious and confronted her, "You've done it again?" She told him, "I didn't bring them, it's God who sent them.... I was here the whole day, in the house." He yelled at her and she pleaded with him to be quiet and not frighten their guests or alert their neighbors to their activities. Finally, she persuaded him to allow them to stay; she smuggled them to the DRC when she saw her husband was becoming increasingly agitated by their presence. ${ }^{63}$

As the genocide continued, Josephine realized she had to placate her husband in order to ensure his silence. She described her efforts in blunt terms.

Even if he talked hell about me or talked to me badly, I didn't show him I was angry because I knew he might go behind me and give them in. So I made sure that even if he said anything, even if he told me to do anything, I would have done it. But just to keep him calm. ${ }^{64}$

But she put her foot down and confronted him when he opposed the rescue of a seven-year-old boy whom she would go on to adopt and raise as her own after the genocide. When he quarreled with her and asked, "What's wrong with you? 
If they get hold of you with that kid, they are going to kill all of us!" she declared that something was wrong with him for turning away a child who was just like their own children. Though it was culturally taboo to challenge one's husband openly, she won the argument. However, she feared her husband would eventually turn on her, so she sent the child to stay with her parents in Bukavu. Ever conscious of the risk, she sent her own children with him to provide a cover story, and "so that they would play together and he [the boy] wouldn't feel out of place or to be with the people he didn't know." ${ }^{65}$ Josephine's husband died soon after the genocide and never saw the recognition Josephine received for her acts of rescue. She lamented that,

I always wished my husband would be still alive. I would want him to see all this, the way people recognize me. I would have wished him to be here and see that actually, what we did, what I was doing, was for a good cause. And also for him to see that it was the right thing to do. ${ }^{66}$

Other women rescuers relied on society's constructed gender norms and social and cultural attitudes that diminished women and rendered them invisible. In addition to these socially constructed norms and attitudes, women's physical appearance proved a determining factor that reinforced stereotypes of weakness and enabled some women to rescue. Ruth is an example of how negative stigmas associated with appearance could benefit rescue. Ruth was devastated by the events on her hill during the genocide.

Because of where I was located, my location, I was seeing [killing] below. I live on a hill. I would see people being killed and I spent the whole day crying. I was like, "This is not happening." And I prayed to God: I said, "God, I know these people are being killed for no reason. I just need you to help me do something for someone at least." 67

Ruth quickly earned a reputation for rescuing Tutsis. The Interahamwe came to Ruth's home often, demanding she give up the people she was hiding. One day, on her way to fetch water, Ruth came upon the site of a massacre and found a newborn infant alive and covered in blood among the bodies. Ruth explained,

They hadn't killed her - many people didn't kill babies because they thought these are little angels so they were like, "You just leave her on top of the other dead bodies, they will die afterwards. But we don't want to kill babies." 68

Even though they were already harboring several people, Ruth ran home and asked her husband for permission to rescue the baby. In her view, she could not rescue the infant without her husband's permission, or at least his acquiescence. With his permission, she retrieved the infant, bathed her by the water source, put her on her back, and brought her home. There, she looked her over carefully. 


\section{Rescuers}

The baby's skin was very thin and she decided, "Since I don't have anything to give this baby, she's still very young, let me breastfeed her." ${ }^{69}$ Her neighbors promptly informed the militias of the new arrival. When the killers came to Ruth's home, she was seated outside, breastfeeding her child as well as the infant. When the men saw Ruth holding both babies and feeding them, they insulted her and exclaimed, "Ah, just leave them, they will die very soon anyway." "70 But they left the infant unharmed. Rush is a slight woman with narrow shoulders and a nervous disposition. The Interahamwe saw her bony frame and believed she was incapable of supporting two nursing infants. But that weak façade belied a tough and determined interior. The infant she rescued is now in high school.

As the genocide intensified, so did Denise's rescue efforts. For Denise, rescuing women was easier at the onset of the genocide than it became later. "They rarely killed the women because they didn't really concentrate on the women.,"71 This trend of sparing women and targeting older boys and men for death was similar to prior instances of violence, including the ethnic violence that occurred during the independence period and in the 1990s leading up the genocide. As a result, Denise assumed she would be safe harboring three Tutsi women in her home. Still, she took precautions. She hid two girls under some clothes as well as an elderly woman in her banana beer pit. She assumed they would be safe until the killings stopped. Soon after the genocide started, however, the killing militias and military began to target women and children, too. Denise soon realized the shift. "After killing all the men, wiping them out, they decided to go back and start killing the women and the girls." 72 Eventually the killers found their way to Denise's home and discovered the two girls. They rounded up the girls and marched them and Denise to nearby Lake Muhazi, intent upon drowning all three. Denise had 20,000 Rwandan francs, less than \$30 in today's money but a small fortune for her and her family, tucked in her kitenge. While it is likely she could have pled for her own life or bribed them, offering a smaller amount, she offered the entire 20,000 to the men in exchange for her life and the lives of the two girls.

I gave them the money and they were like, "This old woman cannot fight us and these girls, we are going to marry them anyway." So they forgave us. They were very pleased with the $20,000[\mathrm{RwF}]$ so they took the money and they left us. They went to drink then, to celebrate, so we went back home. ${ }^{73}$

Denise and the girls were safe - but only for the moment. "Marriage" was a common euphemism for rape. The men clearly intended to return to Denise's home and harm the girls, convinced Denise would be powerless against them. At this point, Denise gave up hiding the girls and the older woman and kept them in her home in the open. She accepted that she would share whatever fate awaited her three charges. But the Interahamwe never returned and the RPF soon entered the area, recognizing the older woman in Denise's keeping as the mother of several prominent RPF soldiers, and moved all four women to a protected 
refugee camp. For Denise, the risks associated with rescuing other women increased over time, after the genocidaires began targeting women and children. Rather than give in or turn the women in her home away, she stood by them, even bribed the Interahamwe killers to save them, and eventually she openly harbored them in defiance of the genocidal norms of the time.

Women rescuers were routinely underestimated, ignored, and diminished by men. This sometimes benefited them and their charges. A number of factors contributed. Blinkered by gendered ideas that women have a limited capacity to take action, men routinely ignored women's agency. Women were thus able to strategize and plan daring rescue attempts that relied upon these gender oversights and enabled them to act "under the radar." For others, socially constructed concepts of gender and space enabled them to hide Tutsis in plain sight, claiming them as kin or hiding them in areas of the compound that were culturally closed to men. One woman played upon men's fear, using superstition and a belief in the supernatural to her advantage. Others benefited from a sexist arrogance that assumed older or physically weak women were incapable of supporting themselves, let alone their charges. The manifold manifestations of agency and action during the genocide lay bare the complexity of women rescuer experiences during the genocide.

\section{Motivations}

Just as the diverging experiences of women rescuers are of primary importance, so are their many motivations. Why did these women determine to rescue when so many others chose instead to participate in genocide? Why didn't they settle for the role of bystander, an often overlooked but necessary component of genocide? Bystanding incurred little risk, required nearly no effort, and Rwanda's patriarchal structure even served as moral cover for inaction. Women rescuers passed on this option. They renounced the ideology catalyzing the genocide and jeopardized their safety to rescue targeted victims of the genocide. Did their religious convictions serve as a catalyst for action and, if so, were more ardent believers more likely to rescue? Did cultural norms and taboos that dictate "proper" Rwandan behavior and forbid murder, such as ubupfura and kirazira, play a determining role? Did stereotypical gender norms, especially those specific to motherhood, influence women to rescue as women and as mothers? Was age a determinant and, if so, were more mature women (age 45 or older) more likely to participate in acts of rescue ? $^{74}$

The women's interviews suggest that religious conviction and gender norms ascribed to maternity and motherhood did play a role. To my surprise, no one mentioned ubupfura. No one mentioned kirazira either, but the women made repeated references to morality and humanity that indirectly indicates knowledge of and adherence to taboos that forbid murder. As to age, while many of the women interviewed were older, they represented a broad range.

Among the host of motivations, religion emerges as a primary catalyst for many rescuers. Wendy, for instance, clearly manifested her faith. She wore a 
cross and religious iconography decorated the living room of her home in southwestern Rwanda. When a family came to her for help, she never experienced any doubt.

When the war broke out, at my home I received a woman, a husband, and their three kids. They came to me to rescue them and I stayed with them [in my home] for a month and a half. So it was at night when they came. They came, they knocked at my door and told me, "We are going to give you a cross. We want you to carry a cross but we don't know whether you will carry it. Would you accept to hide us?" It's like a cross and I said, "Yes, I would do, I will carry the cross and take full responsibility for you." So I hid them. ${ }^{75}$

Wendy hid them in her bedroom and shared a room with her children and grandchild. She explained the situation to them. "If you go on telling anyone, just know that whatever will happen to them, it's going to happen to us. So you have to keep your mouth shut." ${ }^{976}$ Her oldest daughter, 24 at the time of the genocide, helped her to hide them. She understood the risk. "If we told anyone, they would all of us, kill us. So we had to stay quiet." 77

For six weeks, the Tutsi family lived in Wendy's bedroom, opening the door only to receive food and water. Meanwhile, she maintained a façade of normality, hosting her Hutu neighbors who came for regularly scheduled Bible studies and prayer. One day, the Interahamwe arrived and surrounded her home. Wendy was in the garden gathering sweet potatoes when she heard them and rushed back to intervene. Just then, as they were about to enter her home, a whistle blew from afar, indicating that someone had been discovered, and the killers ran in that direction. They never came back, and Wendy and her family never betrayed the family.

When asked what prompted her to rescue, she asserted that her readiness to help was the only feasible response. From her deeply religious perspective, there was no choice to make. "I do believe that God really had a hand in it. I saw different things, women really searching to kill other people's kids, but instead I embraced them and welcomed them in my home." 78 Her daughter explained that while she experienced fear during the genocide, "Even Jesus feared.... Even Jesus in the last minute got scared but because of his love, he had to do it. And so, it's natural. You had to do this although we were scared." $" 79$

Josephine agreed. When asked why she risked her life to rescue, Josephine discussed her faith, insisting, "I won't say it's me, it's God's power. I can't say it's me. Now when I think about it, I'm like 'I couldn't have done it if it was me without God's power.' ",80

Repeated references to God and God's power were a common feature in rescuer interviews. Religious relics, symbols, and imagery decorated many homes. In Rosanne's home there hung pictures of Jesus on the cross, Mary, Jesus, and Joseph together, a psalm written in Kinyarwanda, and another written in French. ${ }^{81}$ Several women, including Josephine and Denise, pointed to lessons 
learned in church or their faith in God as a direct cause for their acts of rescue. When Ruth passed the site of a massacre and found a newborn infant alive among the corpses, she believed that the baby was a divine gift, and not only rescued the girl but breastfed her and raised her as one of her own children. Golda, another rescuer, asserted that it was God's hand that prevented her from fleeing with her husband and children during the genocide. She remained at home alone and was therefore able to shelter a young man who was a family friend and ensure his survival. ${ }^{82}$ Faith in God prompted these women to risk their lives and the lives of their family in order to protect Tutsis fleeing the genocide. Religion and faith were also utilized by the perpetrators to justify the genocide, however. ${ }^{83}$ While faith is a subjective and individual experience, it was an undercurrent in many interviews and played a role in both the perpetration of the genocide, as we have seen with the "Hutu Ten Commandments," as well as efforts to rescue from genocide.

Over 90 percent Christian and with a thriving multi-denominational church culture, Rwandans continue to reference God as a deciding force in their lives, irrespective of their ethnicity. However, while some women perpetrators took a fatalist approach, leaving their fate in God's hands (as we will discuss in the next chapter), others used faith as a source of agency, empowering them to rescue despite the risk. ${ }^{84}$

While none of the women referred to notions of ubupfura in their interviews, some referred to their own maternity and popular gendered perceptions of motherhood - mothers as nurturers, mothers as peaceful, mothers as gentle - as the reason for their acts of rescue. ${ }^{85}$ Initially, Allison was terrified by the killings and hid in her home, but eventually she ventured out in search of food. She came upon a massacre site and saw a child, still alive, among the bodies. She took the girl home and defended the little girl against a local man who reported Tutsis hiding in the area and regularly demanded bribes from her in exchange for his silence. When asked why she took in a little girl she did not even know and gave up so many material possessions in order to save her, Allison's answer was straightforward.

First of all, I am a parent and I know, whatever my other kids would survive on, she would also survive on the same thing. And also, because there was no one to take care of her, really, like a parent, I had to take her up and felt that heart for a kid who had nowhere to go. I just wouldn't turn away from her. ${ }^{86}$

The ethnic identity of the infant did not matter to her; what took priority was that the infant was in need of care. Despite her fear, Allison did not hesitate to rescue and viewed the risk she undertook as a natural extension of her motherhood.

For Janet, a well-regarded teacher in the south who joined the MRND political party to maintain her position, resisting the ethnic divisions taught in school was no small feat. Genocide researcher Jean-Damascène Gasanabo has noted that school instruction and state-approved textbooks codified these divisions and ensured their prevalence. "Instead of trying to eradicate ignorance among the 


\section{Rescuers}

people, a system of propaganda and incitement to ethnic and regional hatred was established by making clever use of that ignorance, ${ }^{87}$ he observed. Still, some women formed opinions independent of the majority. ${ }^{88}$ Janet rejected the MRND party's revisionist history rooted in ethnic tensions and the hatred promulgated by the local political leadership. Her explanation: The Tutsis living in her community were her friends, and her acts of rescue were a result of that family friendship. She did not shirk her responsibility to her community. When the genocide began, she persuaded Tutsi families in her area to entrust their children to her during the genocide. Word got out and others brought their children to her late at night, one by one, and she took them all in.

I would say it is a kind of love I have for their family when they were still alive. The thought of all these families being completely wiped out was also another drive for me to keep these kids and rescue them. ${ }^{89}$

For Janet, her strong sense of community was not rooted in ethnicity, and her sense of mutual responsibility extended beyond her ethnic group to include friends and family irrespective of their identity. Her circle of care extended to the children of every family she knew and she risked her life to ensure that entire lineages would not be wiped out by the genocidaires. With the assistance of a friend, she hid 15 children at a nearby construction site throughout the day; under cover of darkness, she sneaked them into her home to pass the night. The children survived, and Janet went on to adopt and raise three of the children who were orphaned by the genocide.

Friendship also motivated Golda to rescue Vincent, the son of a nearby family friend. Even after her actions were discovered and reported to the local Interahamwe, she did not turn Vincent away; instead, she changed tactics, hiding him at home during daylight hours and in the bush near her home when it was dark. For Golda, the close bond she shared with her friends were of primary importance and extended to their children as well. When asked what motivated her decision to care for him, she explained,

It's because of the kind of relationship our families had with that of Vincent and to me, there is no way you can have a good relationship with the other family and when they come during the hard times, you turn them away. So I decided to do that because of the way we were and the kind of relationship we had, me and his family and his parents. I believe if you have a friend, in good and bad, you are supposed to be together..$^{90}$

For Ruth, her belief in the humanity within every person, regardless of ethnicity, motivated her act of rescue. She did not judge people according to their ethnicity and rejected the extremist rhetoric propagated at the time. "Regardless of all this segregation they talk about, I believe we are all human beings and I never believe in another person killing another, because we have the same blood, to me." $" 91$ 
Denise agreed.

The reason why I even did this? The first one would be there was no reason for them to die. They were like relatives.... And I put myself in their shoes - the fact that if it was me being hunted down and I ran to another person to hide me or I ran to them and they received me, they hid me, that would be something really good. I mean, it wasn't right for someone to be hunted down like an animal and be killed like an animal. For a human being, it's unthinkable. ${ }^{92}$

For Matilde, this humanity extended to the infant she rescued from the bush.

The reason why I rescued her? I knew that she was a human being like me and when I looked at her she was a baby like mine. I had mercy on her. I did not say she is this or this. That's why I took her; I could not leave her while she was alive. ${ }^{93}$

Rosanne rescued four youths because she believed in a shared humanity and because of her family legacy. She began her story quietly, in a timid voice, but she quickly became animated, sitting up and gesticulating with her hands as she described her experiences during the genocide. Rosanne lived near the recently assassinated president's compound, a fiercely contested area controlled by the Presidential Guard and the Interahamwe during the genocide. The anti-Tutsi violence in her area was staggering and an Interahamwe-controlled roadblock was within sight of her home. Still, she hid four youths in a nearby abandoned house, secretly taking them food and water every evening and securing transport for one girl whose fiancé was a Hutu soldier and therefore able to protect her. Using connections through her prayer group, she risked her life to ensure these youths survived. As was the case with many women rescuers, she felt compelled to rescue for a variety of interwoven reasons.

I don't want injustice for any person when they don't deserve it! That one I can't take and I think that way [because of] my guiding force. I also know that the word of God [says] we are all human beings, you are not much different than any other. You are all human beings and that's why I did what I did and the others did not. ${ }^{94}$

Rosanne was also influenced by the experiences of her father during the violent independence period and the first dictatorship. He used to tell her about the discrimination he suffered as a child of mixed ethnic parentage and, throughout the 1960s, her father was repeatedly imprisoned; in 1973, he lost his job because of his "questionable" ethnic status. When the genocide began in 1994, she was motivated not only by her sense of justice and humanity, but also by what her father had endured, and she decided to act in his memory. ${ }^{95}$

A combination of factors influenced most women's decisions to rescue. While Julian explained that her decision to help during the genocide was a result of 


\section{Rescuers}

what was in her heart, she referenced the influence of God throughout her testimony and described her childhood as marked by ethnic unity and peace. "I knew that people are the same, when I grew up my parents loved each other and loved Tutsi and Hutu, they were sharing, we lived with them and shared everything with Hutu, Tutsi, Twa." ${ }^{96}$ As a result of her heartfelt convictions, her faith, and her upbringing, she refused to join the MRNDD political party before the genocide and rescued children and women in her home when murder unrolled.

Other women foregrounded their decision to protect Tutsis in their memories of ethnic violence and parents' and grandparents' rescue activities during Rwanda's early independence period. This transgenerational learning shaped their motivation to rescue, choosing to oppose the genocidal sensitization campaign underway. It also served as an incentive to act, not just stand by and watch the genocide unfold. Thus a familial culture of selfless acts became a primary justification for many women rescuers and for the risks they willingly undertook.

When I asked Martha why she risked her family's life to save six people, she recalled the teachings of her father who rescued his neighbors during the violence that marked Rwanda's independence movement.

One thing I can say is that my father always told me about what happened in 1959 and he told me that, "this happened during 1959" and "never ever scream or [raise an] alarm when someone comes to you for safety. Please, always give them that safety, hide them. Because they almost killed me because I was doing the same thing. Always have that heart of trying, of helping., 997

Martha honored her father's words and, when she saw the opportunity to try to help, she remembered his advice and rescued.

Denise recalled in detail the words of her local leaders, members of the Interahamwe militia.

Before the genocide, I used to hear different groups within the Interahamwe, they would start talking about the Tutsis, that they are wild animals, they are not people. They started really rubbing a bad image about what a Tutsi is like, they are not people, they are real animals. They would say that the Tutsi is a traitor. A Tutsi is not a person who loves a Hutu. They were saying they should be killed everywhere and finish them. So when I saw, when the genocide started and they were now acting on what they were saying, I just remembered what they talked about, actually they meant and they started now putting it into real practice. ${ }^{98}$

But rather than believe the words of her leaders, she chose instead to follow the lessons she had learned in school and in church.

I got teachings from my primary school, my church, they always taught us that we are all the same, regardless of where, your color, your skin, or your ethnicity, you are a human being. You all have red blood. So, to me, those 
are some of the basics or the roots of all the decisions that I made were based on the teachings that I got from all these places that I went to. ${ }^{99}$

Rather than hold the murderous Interahamwe as role models for emulation, she looked to her grandmother's acts of rescue during anti-Tutsi violence in 1959.

Also my grandmother, where I used to stay, told me about the genocide in '59 and told me how it went and how they killed people and also, how they [the grandmother and the grandfather together] also rescued people during that time - they did rescue also. So I followed the same teachings from my grandparents because they did the same action. They saved. They rescued. ${ }^{100}$

Learning from one's parents, grandparents, and role models is a significant yet often overlooked component of the mobilization and militarization process to murder or to rescue, and is referenced by rescuers and perpetrators alike. Sula Karuhimbi, a rescuer who saved dozens of Tutsi in her compound, described the actions of her in-laws and mother during the violence in 1959.

I was seeing! ... my mother came home from grinding sorghum and they hid two men in the fermentation pit and covered them with sorghum flour. Don't you think I was seeing? A child comes from their mother! ${ }^{101}$

Indoctrination of children came first from their parents and elder siblings, who served as the conduits for tradition, ideology, and social identification. ${ }^{102}$ This served both perpetration as well as rescue efforts. Jean, a child perpetrator of the genocide in Rwanda who was granted amnesty because of his age and interviewed by journalist Jean Hatzfeld, described this process in detail.

It is a Rwandan custom that little boys imitate their fathers and big brothers, by getting behind them to copy. That is how they learn the agriculture of sowing and harvesting from the earliest age. That is how many began to prowl after the dogs, to sniff out the Tutsis and expose them. That is how a few children began to kill in the surrounding bush. ${ }^{103}$

A Hutu woman married to a Tutsi man in the same area, Clementine, concurred. "I saw papas teaching their boys how to cut. They made them imitate the machete blows.... The boys usually tried it out on children, because of their similar size." 104 Here we see in graphic detail the importance of parental knowledge and teaching, in this case for perpetrators, and in Denise and Sula's cases for rescuers. Children learned to kill from their parents and grandparents and often families killed together. So, too, did rescuers learn the lessons of compassion, humanity, and bravery from their family elders, emulating them when they aided Tutsis targeted during the genocide.

At first glance, the narratives provided by women rescuers follow a certain formula and a degree of uniformity. The women described the pre-genocide 


\section{Rescuers}

period as one of relative peace and coexistence with their neighbors. Some would note the institutionalized discrimination that marginalized Tutsis. The women narrated the escalating tensions following the RPF invasion, the extremist rhetoric on the radios, in markets, at local meetings, and in the papers, and the sporadic violence that preceded the genocide. They recounted their horror as the genocide swept through their region, hill, and village, threatening the lives of their Tutsi neighbors. The women shared similar experiences of isolation, intimidation, threats, and violence as they endeavored to rescue.

If a pattern prevailed, each act of rescue was singular and unique, and the uniformity born of similarities belies a wealth of variation. The women who rescued did so for a multitude of often overlapping reasons. Religious convictions and belief in a shared humanity before God spurred some women to rescue. Others were motivated by affection for their neighbors or their own child, or due to an extended sense of responsibility for Hutus and Tutsis alike. Still others rescued because of the teachings of their parents and grandparents who, in their own time, had rejected exclusionary rhetoric and rescued Tutsis. And while the arc of their narratives shared many similarities, their day-to-day experiences, survival strategies, and maneuverings are rich both in detail and in variation. While some women relied upon the gendered demarcations of their home to avoid detection, others worked hard to maintain a façade of normality, hosting their Hutu neighbors in their living room while a Tutsi family hid on the other side of the wall. Some women resorted to bribery to save their charges, draining their personal wealth in an effort to save lives. Still others tried to rescue and failed, often with devastating and lasting repercussions.

In every instance, women rescuers defied the genocidal government, took direct action to save lives, and rejected social pressures to participate in murder or, at the very least, be a bystander. As women living in a patriarchal society, their options were limited, but still they persevered.

\section{Notes}

1 Interview R 10 "Elana," interview by Sara E. Brown, Rwamagana, Rwanda, 18 March 2014.

2 Some scholars, such as Jan Grabowski, offer a persuasive argument for inclusion of all rescuers, regardless of financial motivation. My study, however, is limited to rescuers who acted without financial gain. See Jan Grabowski, "Rescue for Money: Paid Helpers in Poland, 1939-1945," in Yad Vashem Studies (Jerusalem: Yad Vashem, 2008).

3 While I cast a broad net when it comes to acts of rescue, I do not include acts of omission - such as observing Tutsis in flight or not reporting the Tutsi hiding in one's field - as acts of rescue.

4 See, inter alia, Vicky Lyn Anderson, "Gender Differences in Altruism Among Holocaust Rescuers," Journal of Social Behavior and Personality 8, no. 1 (1993): 43-58; Debórah Dwork, Children with a Star: Jewish Youth in Nazi Europe (New Haven: Yale University Press, 1991); Martin Gilbert, The Righteous: The Unsung Heroes of the Holocaust (New York: Henry Holt and Company, 2003); and sections of Dalia Ofer and Lenore J. Weitzman (eds.), Women in the Holocaust (Binghamton: Vail Ballou Press, 1999). 
5 Emile Durkheim, On Morality and Society (Chicago: University of Chicago Press, 1973): 112.

6 Ibid.: 83 .

7 Including death, as recounted by Jean Hatzfeld in the chapter "In Search of the Just" in Machete Season: The Killers in Rwanda Speak (New York: Farrar, Straus and Giroux, 2005). See also sections of Edouard Kayihura and Kerry Zukus, Inside Hotel Rwanda: The Surprising True Story ... and Why it Matters Today (Dallas: Benbella Books, 2014); Jean-Marie Kayishema and François Masabo, "The Rwandan Righteous 'Indakemwa' Pilot Study," IBUKA, December 2010; and Carl Wilken's selfpublished memoir, I'm Not Leaving. (2011).

8 This chapter will not dwell on more complicated cases of rescue, such as perpetrators who viewed themselves as rescuers or perpetrators who found themselves in positions where they rescued in addition to their acts of perpetration. Some discussion can be found in Chapter 5, "Perpetrators."

9 Interview S 7 "Rachel," interview by Sara E. Brown, Kigali, Rwanda, 5 March 2014.

10 Cynthia Enloe, "Disposable Life" in the Histories of Violence Project Lecture Series, retrieved March 2014.

11 Debórah Dwork and Robert Jan van Pelt, Flight from the Reich: Jewish Refugees, 1933-1946 (New York: W. W. Norton \& Company, 2009): 201.

12 See Chapter 1, "Finding the Right Flashlight."

13 See Chapter 6, "Post-Genocide Trajectories."

14 Interview R 14 “Joan," interview by Sara E. Brown, Gasabo, Rwanda, 24 April 2014.

15 KGMC interview K 5 "Emereth," retrieved in Kigali, February 2014.

16 Interview R 3 "Wendy's daughter," interview by Sara E. Brown, Murambi, Rwanda, 28 June 2011.

17 Interview R 13 "Golda," interview by Sara E. Brown, Gasabo, Rwanda, 24 Apri 2014.

18 Interview R 10 "Elana."

19 Interview R 7 "Ruth," interview by Sara E. Brown, Kibuye, Rwanda, 22 February 2014.

20 Vouchsafing familial relations to provide additional cover to those in hiding was a common tactic, and has been noted by historians in other cases of genocide or mass murder. See, for example, sections of Adina Blady Szwajger's memoir, I Remember Nothing More: The Warsaw Children's Hospital and the Jewish Resistance (New York: Simon and Schuster, 1990); Tadeausz Piotrowski, Genocide and Rescue in Wolyn (Jefferson: McFarland \& Company, 2000); Jacques Semelin, Claire Andrieu, and Sarah Gensburger (eds.), Resisting Genocide: The Multiple Forms of Rescue. (New York: Columbia University Press, 2011).

21 Interview R 12 "Martha," interview by Sara E. Brown, Gasabo, Rwanda, 24 April 2014.

22 Ibid.

23 Ibid.

24 KGMC Interview K 4 "Julian Nyirabatumwa," retrieved in Kigali, Rwanda, February 2014.

25 Ostracizing those sympathetic to the victim group is a common marker of genocidal culture. See, for example, a discussion of this by psychologists Samuel P. Oliner and Pearl M. Oliner in The Altruistic Personality: Rescuers of Jews in Nazi Europe: What Led Ordinary Men and Women to Risk Their Lives on Behalf of Others? (New York: The Free Press, 1988), and a description of a specific instance in The Forger: An Extraordinary Story of Survival in Wartime Berlin (Philadelphia: Da Capo Press, 2004): 81-2. For an extreme example of the risk incurred by Tuol Sleng prison cadres, see Alexander Hinton, Why Did They Kill? Cambodia in the Shadow of Genocide (Los Angeles: University of California Press, 2005): 238-51.

26 KGMC interview K 4 "Julian Nyirabatumwa." 
27 Interview R 1, S 1 "Margaret," interview by Sara E. Brown, Murambi, Rwanda, 28 June 2011. Margaret's expression of familial solidarity is echoed in other historical cases. See, for example, Nathan Stoltzfus, Resistance of the Heart: Intermarriage and the Rosenstrasse Protest in Nazi Germany (New Brunswick: Rutgers University Press, 1996). See, too, Dwork and van Pelt's discussion of the significance of kinship network and family support to survival through flight in Flight from the Reich.

28 Interview R 1, S 1 "Margaret."

29 Lawrence L. Langer, "The Dilemma of Choice in the Deathcamps." In Holocaust: Religious and Philosophical Implications, edited by John K. Roth and Michael Berenbaum, 221-31 (St. Paul: Paragon House, 1989): 228.

30 Ibid.

31 Fortunately, the government and assisting non-profit organizations understand that, and count Margaret as a survivor.

32 KGMC interview K 3 "Matilde Mukaruhama," retrieved in Kigali, Rwanda, February 2014.

33 Ibid.

34 See Dwork and van Pelt's discussion of these variables in Flight from the Reich.

35 Interview R 8, S 6 "Beth," interview by Sara E. Brown, Kibuye, Rwanda, 22 February 2014.

36 Ibid.

37 Interview S 7 "Rachel."

38 Ibid.

39 Survivor trauma has been identified as a common post-genocide problem. Psychoanalyst William G. Niederland initially identified the "survivor syndrome" among Holocaust survivors in 1964, a condition similarly experienced by survivors of others genocide. See the William G. Niederland Collection at the Leo Baeck Institute for a list of his publications. Since then, a body of scholarship had developed on survivors of the genocide in Rwanda and includes, inter alia, Dominique Eugene and Ani Kalayjian (eds.), Mass Trauma and Emotional Healing Around the World: Rituals and Practices for Resilience and Meaning-making (Santa Barbara, CA: Praeger, 2010); Suzanne Kaplan, "Child Survivors of the 1994 Rwandan Genocide and Trauma-Related Affect," Journal of Social Issues 69, no. 1 (2013): 92-110; Justin Lacasse et al., "The Factor Structure of the CES-D in a Sample of Rwandan Genocide Survivors," Social Psychiatry and Psychiatric Epidemiology 49, no. 3 (2014): 459-65; Laurie Pearlman, "Restoring Self in Community: Collective Approaches to Psychological Trauma after Genocide," Journal of Social Issues 69, no. 1 (2013): 111-24; Maria Roth et al., "Transgenerational Consequences of PTSD: Risk Factors for the Mental Health of Children whose Mothers have been Exposed to the Rwandan Genocide," International Journal of Mental Health Systems 8, no. 1 (2014); and Susanne Schaal et al., "Associations Between Prolonged Grief Disorder, Depression, Posttraumatic Stress Disorder, and Anxiety in Rwandan Genocide Survivors," Death Studies 36, no. 2 (2012): 97-117.

40 Interview R 6 Josephine Dusabimana, interview by Sara E. Brown, Kibuye, Rwanda, 20 February 2014.

41 Ibid.

42 Ibid.

43 Ibid.

44 Ibid.

45 Ibid.

46 A number of scholars, most especially Nechama Tec, have sought to identify characteristics particular to rescuers. See, for example, When Light Pierced the Darkness: Christian Rescue of Jews in Nazi-Occupied Poland (New Haven: Yale University Press, 2003); Gay Block and Malka Drucker, Rescuers: Portraits of 
Moral Courage (Teaneck: Holmes and Meier Publishers, 1998); the alreadymentioned book by the Oliners, The Altruistic Personality; Elizabeth Midlarsky, "Personality Correlates of Heroic Rescue During the Holocaust," Journal of Personality 73, no. 4 (2005): 907-34; and Kristen Renwick Monroe, "Cracking the Code of Genocide: The Moral Psychology of Rescuers, Bystanders, and Nazis During the Holocaust," Political Psychology 29, no. 5 (2008): 699-736.

47 Interview S 9 "Jane," interview by Sara E. Brown, Kigali, Rwanda, 20 March 2014.

48 Ibid.

49 Interview R 14 "Joan."

50 Ibid.

51 Because the "R" and " $L$ " in Kinyarwanda are often interchangeable, Sula is sometimes referred to as Sura.

52 Discussed in Chapter 2, "History."

53 KGMC interview K 1 "Sula Karuhimbi," retrieved in Kigali, Rwanda, February 2014.

54 Ibid.

55 Ibid.

56 Scott Straus, The Order of Genocide: Race, Power, and War in Rwanda (Ithaca, NY: Cornell University Press, 2006): 96-110. For more on the coercive element of participation in the genocide, see Hatzfeld's chapter titled "Punishment" in Machete Season.

57 For more on the roots and variations of umuganda, see Chapter 7, "Sharing Salt."

58 This comprised just over 50 percent of the 20 women rescuers interviewed by me and the staff at the Kigali Genocide Memorial and Genocide Archive of Rwanda (as noted in Chapter 1, "Finding the Right Flashlight"). These women were widowed, divorced, or apart from their husbands during the genocide. None of the rescuers referenced a son old enough to join the Interahamwe ranks.

59 Interview R 11 "Nicole," interview by Sara E. Brown, Rwamagana, Rwanda, 18 March 2014.

60 Interview R 12 "Martha."

61 AVEGA interview A 5 "Patty," retrieved in Kigali, Rwanda, June 2011.

62 Interview R 6 Josephine Dusabimana.

63 Ibid.

64 Ibid.

65 Ibid.

66 Ibid.

67 Interview R 7 "Ruth.”

68 Ibid.

69 Ibid.

70 Ibid.

71 Interview R 9 "Denise," interview by Sara E. Brown, Rwamagana, Rwanda, 18 March 2014.

72 Ibid.

73 Ibid.

74 See Chapter 6, "Post-Genocide Trajectories." The question of rescuer motivation has been explored by a number of Holocaust scholars and their findings resonate with Rwandan women rescuers' motivations. See, inter alia, Gay Block and Malka Drucker, Rescuers; Agnes Grunwald-Spier, The Other Schindlers: Why Some People Whose to Save Jews in the Holocaust (Stroud: The History Press, 2010); Stephanie Jones, "Courageous Altruism: Personal and Situational Correlates of Rescue during the Holocaust," Journal of Positive Psychology 2, no. 2 (2007): 136-47; Mark Klempner, The Heart Has Reasons: Holocaust Rescuers and Their Stories of Courage (Cleveland: The Pilgrim Press, 2006); D. Laub, "In Search of the Rescuer in the Holocaust," Historical Reflections (Reflexions Historiques) 39, no. 2 (2013): 
40-56; Elizabeth Midlarsky, Stephanie Fagin Jones, and Robin P. Corley, "Personality Correlates of Heroic Rescue During the Holocaust," Journal of Personality 73, no. 4 (August 2005): 907-34; multiple publications by Kristen Renwick Monroe including The Hand of Compassion: Portraits of Moral Choice during the Holocaust (Princeton: Princeton University Press, 2004) and "The Ethical Perspective: An Identity Theory of the Psychological Influences on Moral Choice," Political Psychology 30, no. 3 (2009): 419-44; and the aforementioned book by the Oliners, The Altruistic Personality.

75 Interview R 2 "Wendy."

76 Ibid.

77 Interview R 3 "Wendy's daughter."

78 Interview R 2 "Wendy."

79 Interview R 3 "Wendy's daughter."

80 Ibid.

81 Interview R 15 "Rosanne," interview by Sara E. Brown, Kanombe, Rwanda, 29 April 2014.

82 Interview R 13 "Golda."

83 Dr. Patrick Henry ran into a similar issue when examining the motivations of French rescuers during the Holocaust. "Examining religion as a possible motivating factor, for example, demonstrates the thorny nature of the task at hand. Religion often fosters respect for human life but at the same time places people into exclusive groups...." We Only Know Men: The Rescue of the Jews in France during the Holocaust (Washington, DC: The Catholic University of America Press, 2007): 150.

84 See, for comparative purposes, the role of religious faith as a motivation for rescue during the Holocaust in the Oliners' The Altruistic Personality; Mark Klempner, The Heart Has Reasons; Patrick Henry, We Only Know Men; and Agnes GrunwaldSpier, The Other Schindlers.

85 Though not all women rescued children, the rescue of children by women is so prevalent across instances of genocide that it constitutes a separate area of study. A rich body of literature addresses the rescue of children during the Holocaust. See Dwork's groundbreaking history Children With A Star, which opened this field. See too: Nahum Bogner, At the Mercy of Strangers: The Rescue of Jewish Children with Assumed Identities in Poland (Jerusalem: Yad Vashem, 2009); Vivette Samuel, Rescuing the Children: A Holocaust Memoir (Madison: University of Wisconsin Press, 2002); and Suzanne Vromen, Hidden Children of the Holocaust: Belgian Nuns and Their Daring Rescue of Young Jews from the Nazis (New York: Oxford University Press, 2008).

86 Interview R 4 “Allison,” interview by Sara E. Brown, Butare, Rwanda, 20 February 2014.

87 Jean-Damascène Gasanabo, "School History and Mechanisms for the Construction of Exclusive Identities: The Case of Rwanda from 1962 to 1994," in Textbooks and Quality Learning for All: Some Lessons Learned from International Experiences, 365-404 (Paris: UNESCO-IBE, 2006): 371.

88 See the discussion of individuality and the capacity for independent thought as a factor in rescue in Nechama Tec, When Light Pierced the Darkness; Samuel P. Oliner and Pearl M. Oliner. The Altruistic Personality; and Patrick Henry, We Only Know Men.

89 Interview R 5 "Janet," interview by Sara E. Brown, Butare, Rwanda, 20 February 2014.

90 Interview R 13 "Golda."

91 Interview R 7 "Ruth."

92 Interview R 9 "Denise."

93 KGMC Interview K 3 "Matilde Mukaruhama."

94 Interview R 15 "Rosanne." 
95 Ibid.

96 KGMC Interview K 4 "Julian Nyirabatumwa."

97 Interview R 12 "Martha."

98 Interview R 9 "Denise."

99 Ibid.

100 Ibid.

101 KGMC interview K 1 "Sula Karuhimbi."

102 It is worth noting this appears to be the case despite the prominence of the patriarchal church during this period.

103 Jean Hatzfeld, Machete Season: The Killers in Rwanda Speak (New York: Farrar, Straus and Giroux, 2005): 39-40.

104 Ibid.: 40.

\section{References}

AVEGA interview A 5 "Patty." Retrieved in Kigali, Rwanda, June 2011.

Durkheim, Emile. On Morality and Society (Chicago: University of Chicago Press, 1973).

Dwork, Debórah and Robert Jan Van Pelt. Flight from the Reich: Jewish Refugees, 1933-1946 (New York: W. W. Norton \& Company, 2009).

Enloe, Cynthia. "Disposable Life" in the Histories of Violence Project Lecture Series, retrieved March 2014.

Gasanabo, Jean-Damascène. "School History and Mechanisms for the Construction of Exclusive Identities: The Case of Rwanda from 1962 to 1994." In Textbooks and Quality Learning for All: Some Lessons Learned from International Experiences, 365-404 (Paris: UNESCO-IBE, 2006).

Hatzfeld, Jean. Machete Season: The Killers in Rwanda Speak (New York: Farrar, Straus and Giroux, 2005).

Interview R 1, S 1 "Margaret." Interview by Sara E. Brown. Murambi, Rwanda, 28 June 2011.

Interview R 2 "Wendy.” Interview by Sara E. Brown. Murambi, Rwanda, 28 June 2011.

Interview R 3 “Wendy's daughter." Interview by Sara E. Brown. Murambi, Rwanda, 28 June 2011.

Interview R 4 "Allison.” Interview by Sara E. Brown. Butare, Rwanda, 20 February 2014.

Interview R 5 “Janet.” Interview by Sara E. Brown. Butare, Rwanda, 20 February 2014.

Interview R 6 Josephine Dusabimana. Interview by Sara E. Brown. Kibuye, Rwanda, 20 February 2014.

Interview R 7 "Ruth.” Interview by Sara E. Brown. Kibuye, Rwanda, 22 February 2014.

Interview R 8, S 6 "Beth." Interview by Sara E. Brown. Kibuye, Rwanda, 22 February 2014.

Interview R 9 “Denise.” Interview by Sara E. Brown. Rwamagana, Rwanda, 18 March 2014. Interview R 10 "Elana.” Interview by Sara E. Brown. Rwamagana, Rwanda, 18 March 2014. Interview R 11 "Nicole." Interview by Sara E. Brown. Rwamagana, Rwanda, 18 March 2014.

Interview R 12 “Martha.” Interview by Sara E. Brown. Gasabo, Rwanda, 24 April 2014. Interview R 13 “Golda.” Interview by Sara E. Brown. Gasabo, Rwanda, 24 April 2014. Interview R 14 “Joan.” Interview by Sara E. Brown. Gasabo, Rwanda, 24 April 2014. Interview R 15 "Rosanne." Interview by Sara E. Brown. Kanombe, Rwanda, 29 April 2014. 


\section{Rescuers}

Interview S 7 "Rachel.” Interview by Sara E. Brown. Kigali, Rwanda, 5 March 2014.

Interview S 9 "Jane.” Interview by Sara E. Brown. Kigali, Rwanda, 20 March 2014.

KGMC interview K 1 "Sula Karuhimbi." Retrieved in Kigali, Rwanda, February 2014.

KGMC interview K 3 "Matilde Mukaruhama." Retrieved in Kigali, Rwanda, February 2014.

KGMC interview K 4 "Julian Nyirabatumwa." Retrieved in Kigali, Rwanda, February 2014.

KGMC interview K 5 "Emereth.” Retrieved in Kigali, February 2014.

Langer, Lawrence L. "The Dilemma of Choice in the Deathcamps." In Holocaust: Religious and Philosophical Implications, edited by John K. Roth and Michael Berenbaum, 221-31 (St. Paul: Paragon House, 1989).

Straus, Scott. The Order of Genocide: Race, Power, and War in Rwanda (Ithaca, NY: Cornell University Press, 2006). 


\section{Perpetrators}

\section{Gacaca}

Briefly, before delving into the particulars of women perpetrators, it is necessary to detail the creation and implementation of the Gacaca courts, the nationwide legal process that resulted in the perpetrators' incarceration, and the subsequent establishment of the Works for General Interest (TIG) camps. Kristen, an educated and skilled woman, described her genocide crimes as an unfortunate incident born of bad timing, and her sentence as bias against her unusual status as an educated woman. Incarcerated at a TIG facility, Kristen was one of 21 women perpetrators I interviewed who had never spoken to a researcher before we met. Highly intelligent and better educated than most of the women perpetrators interviewed, she spoke in a rich, soothing voice about her experiences during the genocide. According to her, when she heard a group shout, "We've got him! We've got him!" below her hill, she stepped outside of her compound overlooking the Nyabarongo river and watched as they threw a man in the water and drowned him. As her narrative progressed, her level of complicity and accompanying justification shifted. First, she claimed to have seen the killing as it occurred near her front gate. Later, she admitted that yes, she was part of a large group of onlookers, but there were many and she was distinguishable to Gacaca only because of her education, which was unusual for a woman. She then went on to imply that she had been forced to watch. When pressed, she finally clarified: She had joined a killing mob by accident, drawn by the pandemonium outside of her gate. She followed the group to the river and watched as they drowned a man, feeling compelled rather than forced to bear witness to his death. The latter version is what she claimed to confess to the Gacaca courts. ${ }^{1}$ They found her guilty and sentenced her as a Category 2 perpetrator.

Kristen's claim did not make sense. Accidentally observing a murder was not a Category 2 crime. Indeed, bearing witness to genocide was not by and large a crime punishable by incarceration. Gacaca, or Inkiko Gacaca in Kinyarwanda, was established in response to the slow progress of the United Nations court, the International Criminal Tribunal for Rwanda (ICTR), and in order to process the more than 120,000 suspected genocidaires awaiting trial in Rwanda's 19 prisons 


\section{Perpetrators}

that were operating at over 200 percent capacity. ${ }^{2}$ Legal scholar Sigall Horovitz noted that after the genocide,

There was no functioning justice system. Almost all members of the judiciary and most of the country's legal professionals had either died or fled Rwanda during the genocide. Courthouses and prosecution offices were destroyed.... The Rwandan judiciary had to re-invent itself quickly after the war, especially considering the large numbers of detainees who needed to be prosecuted. Judges had to be found and trained, and courtrooms had to be built. $^{3}$

The reviving judicial system simply could not meet the overwhelming demands of the growing caseload and trials proceeded at a slow pace. It was estimated that, without the establishment of the Gacaca courts, it would have taken a century for all of the cases to be tried. The Rwandan government explored a myriad of options before deciding on a modified hybrid version of Gacaca, a traditional conflict resolution process familiar to Rwandans. The Gacaca courts consciously combined the proceedings of a traditional courtroom, the truth and reconciliation method adopted by South Africa, and customary Rwandan procedures of community-based conflict resolution and reconciliation. Designed to meet the needs of a restorative justice process, Gacaca was intended:

1 To reveal the truth about what has happened;

2 To speed up the genocide trials;

3 To eradicate the culture of impunity;

4 To reconcile the Rwandans and reinforce their unity; and

5 To prove that the Rwandan society has the capacity to settle its own problems through a system of justice based on the Rwandan custom. ${ }^{4}$

Four categories of crimes were initially established by Rwanda Organic Law, later condensed into three, and two levels of jurisdiction were established at the Sector and Cell levels. ${ }^{5}$

Based upon witness testimonies and proceeding through public trials, Gacaca relied upon community participation and buy-in. The public was charged with selecting their officiates; elections were held in 2001 to choose the first cadre of inyangamugayo, respected community leaders who would serve as Gacaca "judges." Some 260,000 judges were elected and trained along with other court personnel. After a launch in 2004 and a pilot phase in 2005, the Gacaca courts were implemented nationwide in June 2006 and ran for six years, concluding primary operations in June 2012.

Departing from the ICTR model rooted in international law and in an effort to achieve the first goal of its mandate - to reveal the truth - the Gacaca courts developed a mechanism designed to encourage confessions. In exchange for reduced sentencing and incarceration in TIG work camps instead of prisons, perpetrators were required to first and foremost provide a full and truthful account 
of their actions during the genocide, and, equally important, express remorse. This confession and apology included, when relevant, naming accomplices, identifying victims, disclosing the location of victim remains, and a detailed explanation of the perpetrator's actions. In exchange for their testimony and apology, those who were convicted received half-sentences and, depending on the severity of their crimes, were allowed to carry out a portion or all of their term in TIG programs. These outdoor community-service alternatives included less conspicuous uniforms (dark blue instead of Bahama pink or orange), annual home leave in order to visit family and friends, and a less-severe incarceration environment. As a result of these incentives, many convicted perpetrators offered full renderings of their crimes and the identities and actions of their accomplices during the genocide.

Notably, Gacaca also departed from its traditional patriarchal origins. Legal scholar and former inyangamugayo, Usta Kaitesi, described the original Gacaca system as "a conflict resolution mechanism conducted by elderly men of integrity with the aim of doing justice, reconciling and restoring harmony that would have been jeopardised by the wrong done [emphasis added]. ${ }^{\circ 6}$ Whereas men alone served as the final arbiters of the traditional mediation process, the 2001 inyangamugayo elections were designed to ensure men and women alike would be selected to serve. For this reason and others, Kaitesi asserts that the Gacaca courts represent an "unprecedented progressive system" and judicial platform in Rwanda. $^{7}$

In addition, Gacaca tried men and woman alike. Frequently cited statistics gathered in 2004 estimate that 3.4 percent of the Rwandan prison population was comprised of women incarcerated for crimes perpetrated during the genocide, amounting to nearly 3,000 women. ${ }^{8}$ But drawing conclusions based upon these statistics is problematic as they were collected before Gacaca was implemented. The judicial mechanisms to encourage confessions in exchange for reduced sentencing increased exponentially the number of women implicated by confessors as fellow perpetrators, as well as the number of women tried.

At the Gacaca closing ceremony in June 2012, a report published by the Rwandan government recapitulated its activities and provided basic demographic data. From 2006 to 2012, over 10,000 courts tried 1,958,634 cases and 1,003,227 suspects. In a chart summarizing the number of suspects tried by Gacaca courts according to districts, province, and in Kigali, 96,653 are women, representing nearly 10 percent of everyone brought to dock. ${ }^{9}$ The average acquittal rate for the Gacaca courts was 14 percent (pre-appeals process), which would mean that, if this rate applied to men and women uniformly and without variation according to sex, ${ }^{10}$ approximately 83,122 women were found guilty by Gacaca. ${ }^{11}$ The report also reveals a high level of perpetration variation according to district, with women comprising 15 percent of the total number of people tried in Ngoma district and just 3 percent in Kamonyi district. ${ }^{12}$ These more recent statistics show that a significant percentage of women were tried by Gacaca and belies the gendered women-as-victims or women-as-bystanders categories so often employed by genocide literature. ${ }^{13}$ 


\section{Perpetrators}

With the exception of one woman, Valerie Bemeriki (discussed later in this chapter), the 25 women perpetrators I interviewed are Category 2 offenders. Category 2 offenders were broadly re-defined in 2008 to include:

1 a notorious murderer who distinguished himself or herself in his or her location of wherever he or she passed due to the zeal and cruelty employed, together with his or her accomplice;

2 any person who tortured another even though such torture did not result into death, together with his or her accomplice;

3 any person who committed a dehumanising act on a dead body, together with his or her accomplice;

4 any person who committed or is an accomplice in the commission of an offence that puts him or her on the list of people who killed or attacked others resulting into death, together with his or her accomplice;

5 any person who injured or attacked another with the intention to kill but such intention was not fulfilled, together with his or her accomplice;

6 any person who committed or aided another to commit an offence against another without intention to kill, together with his or her accomplice. $^{14}$

These 25 women had gone through the Gacaca process, confessed their crimes, received reduced sentences, and were serving their time at one of seven TIG facilities located around Rwanda.

\section{Perpetrators}

The 2004 dramatic film Hotel Rwanda shaped western perceptions of the 1994 genocide. Based upon the false accounts of one man, Paul Rusesabagina, ${ }^{15}$ Hotel Rwanda alluded to but avoided direct depictions of the brutality of the genocide. The limited violence that was shown was perpetrated entirely by men. There were no women perpetrators, only women victims, often in tears and huddled behind men. Such scenes did occur and with as much drama as the film so deftly described. But that is not the whole story.

At the same time, when women perpetrators are subject to analysis and discussion, the assessment is gendered, too. One survivor noted that, "Women were actually the worst of all butchers, although they are the one who are considered to be mothers and who should therefore owe respect to human lives." tions of women perpetrators, including the one offered here, often reserve particular horror for the atrocities committed by women. This is reminiscent of the shock expressed in the post-World War II period regarding German women perpetrators. But women's crimes during the genocide in Rwanda were not unusual. Rather, they were similar to those perpetrated by men. The only difference is the gendered reaction that greets women perpetrators.

What did these and other women do during the genocide? Were they all like Kristen, allegedly convicted for inadvertently bearing witness to genocide? The 
crimes perpetrated by women during the genocide fall into two forms: acts of direct violence and acts of indirect violence. The former requires and are perpetrated through the use of physical force, including killing, torture, rape, sexual assault, and beatings. ${ }^{17}$ Indirect violence includes acts that may not require physical force but in Rwanda included looting, theft, knowingly revealing those in hiding to a fatal end, inciting violence, and supervising and ordering instances of direct and indirect violence. As explained by Odette Kayirere, executive secretary of AVEGA Agahozo, and Sabine Uwasi, staff attorney at AVEGA Agahozo, the crimes of women who participated in the genocide in Rwanda fell into three unofficial categories. Ranked according to the frequency and intensity of the crimes, these were: exposing those in hiding by ululating when Tutsi were found in order to draw the Interahamwe; stealing resources and looting; and murdering Tutsis, often children. ${ }^{18}$

Thus, Kayirere and Uwasi asserted that women were more likely to commit indirect crimes by, for example, facilitating the murder of Tutsis by the Interahamwe, the FAR, or other murderous individuals rather than killing Tutsis themselves. Other community stakeholders echoed these assertions, including staff at AERG who held that, typically, men killed while women looted. But they also mentioned less frequent instances of women-perpetrated direct violence. ${ }^{19}$

The first publication about women-perpetrated crimes in Rwanda, Rwanda: Not So Innocent - When Women Become Killers, delineated a similarly broad range of women who participated in direct and indirect crimes. Their list included women who led the killings, who killed willingly, who killed due to coercion and threat of force, who served as "cheerleaders" for the killers, and women who finished off the already wounded. They went on to note that "above all, women and girls stripped the dead - and the barely living - stealing their jewellery [sic], money, and clothes." 20 This detailed list of offenses clearly emphasizes women's perpetration of indirect crimes over direct crimes.

The prevalence of indirect crimes was confirmed by the women perpetrators I interviewed. They admitted to a variety of genocide-related crimes that fell more often under the category of indirect violence, despite the broad list of offenses incorporated into Category 2 genocide crimes. It is possible that women participated in direct crimes to a lesser extent than men solely because they were denied entrance due to their sex into the primary groups tasked with mass murder: the FAR and, for the most part, the Interahamwe. Had women been integrated into these organizations in 1994, more women would have participated in murder. This theory was supported by Odeth Kantengwa, a genocide researcher in Rwanda and former fellow at the Rwanda Women Network, who noted that a culture of sex-based exclusion resulted in fewer women implicated in the genocide. ${ }^{21}$ Nevertheless, the statistics prompt a number of questions: What were the specific crimes of women during the genocide? Were they voluntary? What were the circumstances of their perpetration? Are women frank about the crimes they perpetrated? And do they experience remorse? 


\section{Perpetrators}

\section{Direct violence}

Suzanne, a gentle-appearing elderly woman, walked into our makeshift interview room in a TIG camp in Muhanga district. Borrowed from the camp administrators, the room was furnished with a hand-made bench and stool alongside a table piled high with handwritten ledgers. My interviews followed a semistructured script, ${ }^{22}$ but this one quickly went off course. After obtaining Suzanne's consent to be interviewed, which she enthusiastically gave as she clutched her white plastic rosary beads in both hands, I asked her for some basic biographical information. I then asked her to relate her background and how she came to be at this TIG camp. She replied in a sweet and matter-of-fact tone, “The reason why I'm here is because I'm accused, I actually killed my grandson, one of my grandkids during the war. That's why I came here." ${ }^{23}$ Without pause I asked, "Did you kill the child directly?"

It is necessary to pause here and acknowledge the layers of complexity in this exchange. It is difficult to sit across from convicted perpetrators and ask them to detail their crimes. Holocaust historian Saul Friedlander noted that scholars of the Holocaust struggle to,

keep some measure of balance between the emotion recurrently breaking through the "protective shield" and numbness that protects this very shield. In fact, the numbing or distancing effect of intellectual work on the Shoah is unavoidable and necessary; the recurrence of strong emotional impact is also often unforeseeable and necessary. ${ }^{24}$

Feminist scholar Carol Cohn once wrote of her own experiences,

Putting genuine intellectual curiosity - the desire to understand - at the center of who I am when doing research is not difficult. But some of the situations in which I have practiced that centering have made me feel that my head would explode. ${ }^{25}$

I was ever cognizant of the necessity for me to maintain emotional distance and give primacy to my intellectual curiosity for a number of reasons; chief among them was my position of authority as "the researcher" during these interviews. I tried to mitigate any influence my reactions - spoken or unspoken cues to my inner thinking - may have had on the trajectory of the interview or the respondent's narrative. With this in mind, I deliberately engaged in what I later termed "purposeful neutrality" when interviewing perpetrators.

Suzanne was 83 years old at the time of our interview and suffering from severe memory loss because of her age, and perhaps also from the trauma she experienced as a result of her crimes. This led to divergent versions of her complicity. Suzanne initially explained that she helped to murder her grandson at the behest of her daughter, who had borne a child with a Tutsi man who then left her to marry another woman. Later, Suzanne recanted her story and asserted that she did not kill her grandson; rather, she stated that her husband helped their 
daughter to kill the boy while she stood by, coerced into the role of bystander by her husband and daughter. In both versions, the role of her daughter, who partook in the killing of her child and is now incarcerated in prison, was never disputed. During the second telling, it is worth noting that Suzanne asserted that her husband and daughter killed the child out of fear that the Interahamwe would find him alive and kill all of them. When pressed for proof of this fear, such as a verbal threat, it was not clear whether her trepidation had been real, imagined, or constructed in order to assuage her guilt. ${ }^{26}$

Suzanne's narrative revealed her fraught feelings about the murder of her grandchild. Other women were so enthusiastic about killing that they began to target Tutsis before the genocide even began. Take the case of Valerie, as told by Nathan, a child of mixed parentage, born in 1984. He did not attach any significance to the fact that his mother was a Tutsi and his father a Hutu until officials entered his classroom in the early 1990s and separated the students according to ethnicity. He explained, "They would say, 'Those who are Hutu, go to this side' and then I would go there, and then 'Tutsi, go to this side' and then I would go there." ${ }^{27}$ After the "Hutu Ten Commandments" were published and as tensions escalated in 1992 and 1993, his father began to receive threats from their neighbors because his wife was a Tutsi. He was called a "traitor" to his ethnic group and a "snake with two heads." An elderly neighbor named Valerie repeatedly threatened Nathan's mother, telling her, "YYou know, one day you will die." "Nathan's family made light of her threats. "She's just saying that because she hates her [Nathan's mother] as everybody hates her [Nathan's mother] in the neighborhood - it's not a big deal." 28 They brushed aside neighborhood hostility and did not relocate or leave the country.

Then, one afternoon in 1993, Nathan's mother collapsed and was rushed to the hospital. The following morning, she died from apparent poisoning. The family was devastated. Shortly thereafter they received a handwritten note with a Kinyarwanda proverb: uwicimbwa urashaka nyirayo, or "someone who kills a dog wants the owner." Nathan interpreted its significance: "If you see your dog killed, it's because actually, they just want your head. It's not the dog that they are looking for." 29 The message was clear: though Nathan's mother was the victim, his father was the intended target. The neighborhood buzzed with rumors, and Valerie quickly took credit for the poisoning and the note. But given the tensions of the time, the threats facing Nathan's family, and the implications of the note that marked Nathan's father for death, the family did not seek justice for Valerie's crimes. This was compounded by the complicity of the community which supported the murder, either through vocal support or silent acquiescence.

One form of direct violence, women-perpetrated rape, is glaringly absent from the mainstream narrative of the genocide - although it did occur. According to Janvier Forongo, then executive secretary of IBUKA, numerous instances were reported in which women forced Tutsi boys and men to engage in sexual acts out of a desire for revenge and to dishonor the victims. ${ }^{30}$ Sociologist Ruth Seifert reminds us that, "rape is not an aggressive manifestation of sexuality, but rather a sexual manifestation of aggression. In the perpetrator's psyche it serves 
no sexual purpose but is the expression of rage, violence, and dominance...." ${ }^{\prime 3}$ These acts of sexual violence are intended to shame the victims as well as the community, tearing at the social fabric that binds them together. But then Seifert went on to conclude, "... over a woman." 32 Seifert's inclusion of "over a woman" illustrates how a system of gender roles has masculinized rape perpetration and feminized its victims. Men are assumed to be the perpetrators and wielders of power and aggression, and women are the assumed victims of that aggression. While this is too often the case during genocide, and Rwanda is no exception, that paradigm leaves little room for an inclusive discussion about the rape of men or women perpetrators who rape. Sexual violence researcher Inger Skjelsbæk notes the gender gap in documentation. "The documentation of sexual violence against women is widely seen as suffering from being anecdotal, but in the case of men the situation is even worse." ${ }^{33}$ And when men are victims of rape, their experiences are explained using feminized terms that are later adopted by the victims. One man described the experience of rape as having been made the perpetrator's wife. ${ }^{34}$ That de-masculinization, indeed that feminization, created an additional source of shame and exclusion from the community.

Silence prevails as a result of this gendered stigma that emasculates and isolates male victims of rape. A 2011 Guardian article about men victimized by rape highlighted this.

Of all the secrets of war, there is one that is so well kept that it exists mostly as a rumour. It is usually denied by the perpetrator and his victim. Governments, aid agencies and human rights defenders at the UN barely acknowledge its possibility. Yet every now and then someone gathers the courage to tell of it. ${ }^{35}$

In Rwanda, to be a man victimized by rape is to be likened to a woman and considered "no longer a man." Many prefer to remain silent, obscured by the same gendered lens that obfuscates the role of women perpetrators. This makes it difficult to find men victims willing to be interviewed. Just one agreed to speak to me.

Charles survived women-perpetrated gang rape during the genocide. He recounted his experiences in detail. Trapped in Kigali, he eventually found refuge in an abandoned home and hid there with his ailing friend, aided by an elderly woman who occasionally brought them food and water. One afternoon, she arrived and used a pre-arranged knock to alert Charles to her presence. He soon saw that she was not alone; she entered the house accompanied by four armed women. Charles described them as devils armed with "knives and grenades around them." The four women asked him, "AAre you cockroaches?", They then asked, "If we wanted you to do some things for us, would you do them?" Eager to avoid death, he said he would do what he could but he did not know what they meant. ${ }^{36}$

Charles then recounted how he was drugged with a white powder that he was instructed to inhale up his nose, injected with a liquid through a syringe, stripped 
naked using a knife, and tied to a bed. At this point, the woman who had brought him food was sent away and the door was locked behind her. Over the next three days, Charles was repeatedly drugged and raped by the four women in shifts. He was in considerable pain but could not stop.

It was so shameful. Very shameful. Violence really hurts. There are times when people just say the word but they don't really give it its content. To be raped is something unusual. It's unbelievable. ${ }^{37}$

Charles stressed that he was not alone in his victimization; he knew of other men who had experienced sexual violence at the hands of women during the genocide. However, no one else came forward. After the genocide, Charles' recovery was long and laborious. His physical and psychological wounds never fully healed and his status in society remains compromised as a result of his victimization. His identity is tied to his experiences of victimization. Still, this is shifting; the last time I visited with Charles in 2014, he had been appointed the leader of the survivors in his community. But the sex crimes of women have largely avoided the scrutiny of Gacaca. Charles never saw his abusers brought to justice; he heard a rumor that they had fled to the Democratic Republic of Congo and died there.

\section{Indirect violence}

While some women, like Valerie, perpetrated crimes on their own, most participated as part of a collective. And even in the case of Valerie, though she may not have been part of a group, the community supported her actions. When the genocide began, Tutsis were often murdered by killing mobs - groups who sought out Tutsis to murder. This was intentional, as it served to implicate everyone in the genocide, and was a purpose behind the formation of the Interahamwe, or those who attack together. A number of women were incarcerated for their participation in such groups. Women did not need to wield the weapon that delivered the death blow; their participation in a killing mob constituted an endorsement of the killing and an act of indirect violence. This was the case for Kristen, discussed previously, and for Agnes, who claimed that she was imprisoned due to her curiosity. She explained that she was at home when, "I heard people were around the place, I decided to go and see what was going on. And because I did that they blamed me for having participated." 38 Agnes refused to accept the testimonies of other members of the group, who asserted that she not only participated in murder but also aided in the discovery of Tutsis hiding in her area. Cindy, another woman accused of participating in a killing group, argued that she joined the others only after they had killed someone. She claimed to have "landed on a group of people who had finished killing someone and they were burying that person" and remained in order to watch the burial. ${ }^{39}$ As a result, she argued, she committed no crime. But it is necessary to acknowledge Cindy's agency, as limited as it may have been, and complicity. She chose to 
remain with the group as they buried their victim and therefore participate in an act of indirect violence within the necessarily broad understanding of genocide perpetration.

Indirect violence is no less dangerous or murderous than direct violence. The most well-known woman perpetrator of the genocide in Rwanda, Pauline Nyiramasuhuko, former Minister of Family and Women Affairs, perpetrated indirect violence on a genocidal scale. Nyiramasuhuko did not need to lift a machete and kill. As a woman of high rank and authority, she ordered and supervised abductions, detentions, murder, rape, and torture that were perpetrated by the Interahamwe and her son. ${ }^{40}$ Interestingly, she asserted her innocence by claiming, "I couldn't even kill a chicken. If there is a person who says that a woman, a mother, could have killed, I'll tell you truly then I am ready to confront that person." ${ }^{41}$ The ICTR judges did not accept her gendered argument; in June 2011, Nyiramasuhuko was found guilty of genocide, crimes against humanity, and war crimes.

Another instance of indirect violence perpetrated by a woman of high rank can be found in the role of Valerie Bemeriki, the RTLM radio journalist renowned for her extremism. As we have seen, ${ }^{42}$ while print media played a significant role in catalyzing participation in the genocide, the radio was, as scholar and human rights activist Alison Des Forges observed, "more effective in delivering the message of hate directly and simultaneously to a wide audience," 43 and Valerie Bemeriki was one of its most popular personalities. ${ }^{44}$ Bemeriki, aware of RTLM's extremist intentions from the beginning, was eager to join RTLM radio and left her position as a writer for two MRND print periodicals to become a radio journalist. ${ }^{44}$ Her role in perpetuating RTLM's message of genocidal hatred and violence was especially meaningful as she was one of just four women journalists at RTLM. But while Bemeriki worked alongside other women, her name stood out in interviews as the only woman radio journalist memorable enough to mention.

Bemeriki eagerly accepted my request to interview her. She promised a full and frank account, and she presented herself as a model for rehabilitation. She asserted she had cast away the genocidal ideology she had previously promulgated in an effort to promote peace in Rwanda. On the appointed day, we spoke at some length about her early career, RTLM recruitment, experiences during and following the genocide, and her role in its perpetration. Bemeriki deftly diminished her role throughout the interview. She spoke with ease in general terms about the genocide, and with passion about Hutu hardships in the Congolese refugee camps following the genocide. She recounted in great detail the evening the president's plane was shot down, describing her efforts to reach the airport and how she drove into live fire twice in order to report the story. But when she addressed the genocide, she did so in vague terms, brushing over the events that took place between 7 April and 4 July 1994. In contrast to her emotional depiction of Hutu suffering in Congo, she described the mass murder of Tutsis in brief, using callous terms. She used the expression "fighting for our rights" repeatedly to describe Hutu aggressions during the genocide. Insisting that she never saw dead bodies in Kigali, she reasoned speciously, 
Here in Kigali you could not see dead bodies, the trucks and machines for MINITRAPE [Ministère de Traveaux Public] were collecting dead bodies across the town, in the countryside when they killed people, they dumped them in rivers or somewhere else where you could not easily see. Surely I cannot say that I didn't see any dead bodies, I maybe saw one or two.... ${ }^{45}$

Once the genocide began, Bemeriki insisted that she did not go out much because she was afraid, limiting her travel to her daily commute to the radio station. The same woman who proudly depicted her bravado on 6 April suddenly hid from the fighting when there were stories to report. She apparently also lost her journalistic curiosity. "The other thing I saw is that they would snatch people from cars and arrest them on road blocks, but you couldn't know what they were doing with them., ${ }^{\prime 46}$ Bemeriki alleged she never bothered to ask, perhaps uninterested in the scoop. It is apparent that Bemeriki did believe in a Tutsi threat and experienced fear during the genocide. However, it is difficult to reconcile the woman who faced live fire twice to report on the death of President Habyarimana and whose fiery rhetoric during the genocide earned her infamy even today in Rwanda with the woman who allegedly hid for the remainder of the 100 days.

In her role as an RTLM announcer Valerie Bemeriki repeatedly incited violence before and during the genocide. Broadcasting messages of hate, she called upon the Hutu population to engage in genocide-related crimes. Seeking to ensure uninterrupted continuation, she promoted violence, often veiled in euphemisms and language of self-defense, against RPF assassins and infiltrators. ${ }^{47}$ Still, she became visibly uncomfortable and defensive when asked about her role in catalyzing genocide, a clear act of indirect violence. Throughout the interview, she repeatedly positioned herself as the victim of the pervasive hate propaganda in 1994, rather than one of its leading protagonists. At the very least, she demoted herself to the rank of a soldier who followed orders, reading lines written by others, swept up in events that she could not control. Her attempts to indemnify herself from complicity in the genocide and place blame on her superiors were predicated on a rejection of personal agency. At one point, flustered when questioned about specific language she had used during her radio show, she interjected.

I want to make a small comment. When they say that at RTLM, we were encouraging people to participate, you need to know that it was not coming from us. Even though on one hand we believed that we were defending ourselves, the announcements and what we read were coming from the Army joint staff because they had information of where they said RPF soldiers were hiding. So we would read them and government soldiers and Interahamwe would go to the specific locations mentioned to kill whoever was around, be them Tutsis, children or anyone around. ${ }^{48}$

When asked if she believed her position as a leader and role model for Rwandan women influenced them to participate in the genocide, she replied in vague 


\section{Perpetrators}

terms. "It is possible, but remember at that time they didn't see it as genocide, of course they followed what I was saying, it was like a call to defend ourselves." 49 Bemeriki went on to assert that she was not the only person calling for genocide and to deflect attention from her role as a promoter of genocide. According to Bemeriki, her participation, which was part of a larger strategy to rouse the masses and encourage them to commit genocide, was not the real crime. She absolved herself of blame by shifting it to the radio's audience. In her mind, the real crime lay with her listeners, who chose to believe her hateful rhetoric, repeated day in and day out for months. ${ }^{50}$

\section{Voluntary agency}

In general, the women described their participation in the genocide, if they admitted it at all, as voluntary. For example, although Kristen initially implied that her participation in the mob drowning of a man was a result of coercion, she later changed her account, according herself greater agency. But this voluntary agency was constrained by women's subordinate status in Rwanda. In some sense, women's participation could not be voluntary due to the patriarchal society that required obedience to men. When Suzanne asked her husband how her grandchild died, he admonished, "Don't you know how other people are dying?" She went on to explain that, after hearing his response, she could not challenge him, the head of the household, or question him further. "From that, I couldn't add any questions. I just kept silent." ${ }^{51}$ Vanessa, another respondent, readily confessed to being present when her brother and a nearby Interahamwe militia drowned a mother and four children and another brother killed the grandmother. According to her, as a woman, she had no choice but to stand by and watch, overlooking the fact that she could have walked away. Instead, she chose to participate as a witness. "If I had the power to stop what was happening, I would have done something.... There is no way you could confront any Interahamwe and say, "Stop what you are doing.,",52

Even as society was falling apart in the period leading up to and during the genocide, many of the rules controlling women remained in force. Most women were restricted to the domestic confines of their compound and farmland. Rose was caught by surprise when the genocide began and reasoned this was due to her gendered isolation. Asked if she heard or saw anything before the genocide unrolled in her area, she replied, "Usually when you are girl, what you do is you stay home, you eat, you do what you're being told. I didn't really focus on really putting my concentration on the radio or what." ${ }^{53}$ Cassie claimed to know little about the genocide taking place in her area since "most of the time I was at home." 54 Tracy concurred and added her domestic responsibilities as another reason she was caught by surprise.

I didn't know anything was going on outside until - this just came, like, abruptly. Unexpected. It's not that I had a radio to listen to. I never had a radio. Most of the time I was at home. I'd go to the market once in a while 
but I never heard anything in the market. I was more trying to find food for my family. ${ }^{55}$

While domestic spaces and responsibilities are gendered, pregnancy is a uniquely female experience. Elaine explained her limited mobility, and with it agency, as a result of her pregnancy and domestic responsibilities. "Most of the time I was home and I was pregnant, I had kids so all I could do was go in the garden close to home."56 Still, while a woman's agency was constrained, the existence of women rescuers ${ }^{57}$ proves that it was not wholly compromised; it was possible to say no or to abstain from violence. For example, while it may be true that Valerie Bemeriki did not draft the lines she read on the radio, she could have refused to read them. Beyond losing her job and status, the consequences would likely have been minimal. Only one woman, Jennifer, portrayed her participation as a result of the direct threat of violence. Serving a ten-year sentence for her crimes, Jennifer expounded,

They forced me to bring the stones.... The reason why I'm here is because during the genocide I was at home and then I heard an alarm.... I found they had thrown a person in the well and they were throwing stones at that person.... I was ordered by the men who were throwing stones at the person in the well who was drowning - they ordered us to bring stones. So I went to bring the stones. That's why I'm accused, that's why I'm here. ${ }^{58}$

And while Jennifer acknowledged that her participation was involuntary, she also accepted her sentence and expressed remorse for her role in the man's death. "The first thing I want to do when I go back [home after completing her TIG sentence] is to find the mother of the person I killed and ask for forgiveness." $" 59$

Jennifer was the only woman who claimed to participate as a result of direct threat of force, but two other women described their participation as unintentional: one as a result of trickery and the other due to accident. During the genocide, Elaine's in-laws hid Protaise, a Tutsi man who was a neighbor and close friend of the family. One afternoon, on her way home from a visit with her inlaws, she was approached by another neighbor who confided in her. He claimed to have secretly assisted two Tutsis, a man and his wife who were well known in the community. This neighbor went on to lament the loss of his friend, the very same Protaise protected by Elaine's family, and with whom he had shared beers for many years. When the man claimed a desire to aid Protaise, Elaine believed him and told him of Protaise's whereabouts and her family's role in hiding him. Later, when she learned that Protaise had been killed by that very same neighbor, she realized she had been tricked. Even though she alleges she had unknowingly contributed to this man's death, she confessed to Gacaca. ${ }^{60}$

Rose was a young woman still living at home when the genocide broke out in her region. She readily explained why she was serving a sentence at TIG. One day, she was given a common chore for children: walking to the garden (sometimes a distance away) to gather vegetables for a meal. While she harvested 


\section{Perpetrators}

beans, a man who was concealed among the banana trees jumped up and startled her. She screamed aloud and ran home. The man fled in the opposite direction. On her way, Rose encountered FAR soldiers who increased her terror since, "of course everyone used to fear soldiers." ${ }^{\prime} 1$ They questioned her and ran toward her family's garden when they learned of the man hiding there. Only later did Rose learn that the man was a Tutsi fleeing the FAR soldiers, who then murdered him near Rose's family farm. When asked if she felt complicit, Rose paused for a moment before responding, "I got scared. He ran away and afterwards he was caught because of me. So it's like it's a joint deed between me and the soldiers. ${ }^{\prime \prime 2}$ It is noteworthy that, contrary to the reactions of the other women incarcerated for genocide crimes, both Elaine and Rose viewed themselves as complicit in each respective murder, even though they were not a result of deliberate intent.

In the other testimonies, the women described their involvement, if at all, as a result of their own admittedly gendered and therefore constrained volition. Tanya, the self-proclaimed "general" of the women in her TIG camp, was very straightforward about her participation in the genocide, a contrast to the common rule. When the local Interahamwe militia, led by the local Conseilleur, Innocent, came to recruit in her area, Tanya volunteered to collect stones for an assault on a nearby church. In the end, her story was not so simple. She detailed the assault on Tutsis gathered at a nearby school complex, and the letter she wrote to Gacaca to confess her crimes before the trials even began. At the end of her narrative, she acknowledged her (surprisingly brief) sentence of five years at a TIG camp. And then she mentioned in passing, "We had hidden one Tutsi at home."

Pressed for details, Tanya explained that after the genocide began, the son of a nearby neighbor, nicknamed Magahura, arrived on her doorstep in the middle of the night in search of refuge. She and her husband quickly brought him inside though they both knew that in harboring Magahura they put their entire family at risk.

They used to tell us that we should check around everywhere for any remaining Tutsi.... We would hear that on the radio, saying that even those that are hiding them, if you find them hidden in their homes, kill them with him or her. ${ }^{64}$

Magahura stayed locked in the house during the day and slept under Tanya's bed at night. He had been with them for a week when Tanya volunteered with the Interahamwe.

When they [the Interahamwe] came to collect us and mobilize us to go and pick the stones, I didn't want to cause any suspicion, so I made sure - I didn't want them to come in the house! - so I went outside when they said, "Come out!" So I went out and I locked my kids in and Magahura in the house. I locked them in. ${ }^{65}$ 
In order to draw the Interahamwe away from her home, Tanya followed the militia to the school complex and gathered two stones. When the assault on the school began, Tanya fled to a nearby banana plantation. According to her, the Interahamwe, assisted by FAR soldiers, threw stones, showered the complex with bullets and grenades, and killed every Tutsi. But Magahura survived. When Tanya came before Gacaca, Magahura testified on her behalf, explaining her actions in the context of his rescue, and thus ensured that she received a significantly reduced sentence. Still, when asked if she felt any regret for picking up the stones when she sought to save, not murder, she replied,

Every time I go home, I tell them [her children], "In case anything happened, when I'm not around ... always lock yourselves in the house. If they want to kill you, they will kill you in the house. Don't accept if you are going to do anything."

Although Tanya's crime facilitated the survival of one man and perhaps her entire family, the Tutsis at the school died. She did not want her children to incur a similar fate. As a result, Tanya preferred death over participation in another genocide.

Another woman, Amy, described her participation in a plot to kill Tutsis as voluntary, even enthusiastic. She joined a group that included Interahamwe in order to plan an attack on Tutsis in her area. In the end, she claimed that the opportunity to kill never presented itself; her crime was solely one of intent. ${ }^{67}$ In general, while many women did admit to a varying degree of agency during the genocide, they typically focused on denying their crimes or evading my questions. Still, these diverging stories of perpetration and agency elucidate the complexity of women-perpetrated violence during the genocide.

\section{Denial}

Charlotte was in the middle of a 15-year prison sentence that had been reduced and transferred to a TIG facility following her confession when I spoke with her. She was also one of just four women who had been interviewed previously by foreign researchers and seemed well prepared for our meeting. Charlotte was found guilty of killing two children - a boy and a girl - and their grandmother during the genocide. Though Charlotte had given a full confession and begged forgiveness, when she sat down to be interviewed, she adamantly denied her crimes. Asked how she came to be at TIG, she offered an animated and lengthy explanation.

The reason why I'm here is because of the war that happened in this country. There are so many people who participated in the genocide but there are also those who did not participate but are accused of having participated in the war. So many have come here not because they participated but because they are being accused that they participated. Like me, I was accused that I killed people. I didn't kill any. I didn't and I've never killed anybody during the genocide. ${ }^{68}$ 
Charlotte was insistent, repeatedly admonishing me to put down my pen and wait until she finished her explanation of how she was framed for crimes she never committed. Her account was replete with intrigue, incompetent inyangamugayo, and deception. She explained that she had accepted the crimes, confessed, and begged forgiveness, but only in order to leave prison for a TIG camp and shorten her sentence.

Such efforts to diminish or obfuscate complicity were common and an unexpected issue I encountered repeatedly. Women described their participation in ambiguous terms, often contradicting themselves mid-interview. Of the 26 women interviewed, 22 denied their involvement in the genocide on some level, often entirely, and insisted that while they had confessed their guilt before the Gacaca courts, frequently in great detail, they were not truly guilty. Repeatedly, these same women insisted that the genocide erupted abruptly, without their knowledge or expectation. As Charlotte insisted, "I didn't hear anything really. Not even in markets. I didn't hear anything being talked about." ${ }^{\prime 9}$

Denial by women perpetrators is an acknowledged phenomenon. When asked about women perpetrators of the genocide in Rwanda, one man perpetrator noted that women "are more reluctant to admit their crimes. When they have done what they have done, they keep silent." ${ }^{70}$ Still, when pressed, some of the women recounted participating in mobs that murdered with machetes and clubs or by drowning, exposing Tutsis in hiding, encouraging others to participate in killings, and theft. And in some instances, it was possible to verify their testimony by accessing the Gacaca Court Archives located in Kigali and reviewing their court cases.

Kristen, for example, was found guilty even though she insisted that her participation was accidental at best and limited to the one drowning. Her case was one of nine testimonies randomly selected from 25 interviews and verified at the Gacaca Court Archives. ${ }^{71}$ Review of the 25-page handwritten transcript of the Gacaca proceedings detailed a level of involvement in the genocide far beyond what Kristen described in her interview. Numerous survivors and witnesses recounted Kristen's enthusiastic support for the extremist political party, Coalition pour la Défense de la République (CDR), often wearing the party colors in a display of loyalty. It was determined through witness testimony that Kristen regularly threatened young Tutsi women fetching water at the well, often refusing them access. Kristen's participation in the drowning of a man in the Nyabarongo river was also documented in the Gacaca transcripts. In it, her contribution to that murder was not restricted to an accidental witness, as she firmly claimed; contrary to her testimony when interviewed, the court records revealed that her participation began at a neighbor's home, where the victim was first tortured, and that she was present when he was later transported to the river and drowned. These transcripts indicate that Kristen's role in the 1994 genocide was active, up-close, and enthusiastic. ${ }^{72}$ She did not accidentally chance upon a mob in the midst of drowning a man. She was an active supporter of the genocide and a proponent of the extremist ideology behind its perpetration. 
In some instances, the women omitted a portion of the accusation levied against them, including corroborating details provided by witness, survivor, or perpetrator testimonies that were documented in the archived court transcripts. The Gacaca Archive transcripts confirmed that numerous respondents were less than truthful. Of the other eight cases reviewed, translated, and compared to the testimony provided during my interviews, six had substantial inconsistencies. Asking the same questions in a multitude of ways exposed inconsistencies in the narrative, but did not evince a confession. The women continued to deny or diminish their crimes.

Deena claimed that she was sentenced to 25 years in prison and TIG for not reporting a dead body she happened upon during the genocide. As the accidental discovery of a corpse would not merit such a lengthy sentence, I pressed for further details. Accused by a survivor who found her with the corpse, she insisted that she had not felt the need to come forward because "it wasn't necessary," as everyone else had remained silent. But who was everyone else? As it transpired, she had joined a group that killed a man, the very corpse she claimed to discover accidentally. Even then, however, she refused to acknowledge complicity in the murder. She fell back on her sex and presumed weakness as a defense. "Even if they thought I killed the other person, it wouldn't be realistic. He was a strong man by then. There was no way I could have done it." 73 Still, she had agreed to confess. "I accepted the crime of having been there and not reporting," she said, but not without insisting that there was a nefarious plot that resulted in her incarceration. "There was a conspiracy between the woman we were with, who went ahead and told the people in Gacaca and twisted the whole case. They pinned it on me." 74

Laura's denial took another form. At the very beginning of our interview, before I pushed the record button, she jumped up from her seat and began to pray, swearing to Jesus and God that she would tell me the truth. Twenty years old at the time of the genocide, she described her and her widowed mother's failed efforts to save a Tutsi man concealed in their home. According to her, when the Interahamwe arrived, they demanded she give up their charge, and beat Laura when she denied harboring a Tutsi. After storming the house, they offered the women two choices: either give the man up to die or pay a fine to spare his life. Because Laura did not possess any money, the man was taken and killed. In the end, she was found guilty of giving the man to the Interahamwe. ${ }^{75}$

Despite the disjointed telling and occasional problematic point embedded in her testimony, Laura's account was plausible. But she claimed not to know the name of the man they were trying to rescue. I probed further: Did he stay in the garden or in your home? In the home. For a few minutes or for longer? Overnight. Did your mother know this person? No. It seemed highly unlikely that a widow and her young daughter would invite a strange man into their home without asking his name. So I asked, "They took this man and they killed him. And you don't remember his name?" To which Laura replied, "I don't remember his name. It's been a long time." 76 At this point, her narrative began to unravel. While she did not challenge the reliability of the witnesses who spoke against 
her at Gacaca, she claimed that she was imprisoned only because she could not afford to bribe the inyangamugayo for her freedom. When asked if she ever saw other women participate in the genocide, she inadvertently implicated herself and suggested she was coerced into participating.

What happened is that there were no women in all these groups that were killing people but most of them would - they got involved in the same way I got involved. Not because you wanted someone to be killed but sometimes they would come and torment you or torture you and you would give in. ${ }^{77}$

Then, after initially admitting to hearing extremist rhetoric at political party meetings, she went on to deny being a member of a political party or participating in political activities. She quickly changed her tale to assert her innocence and ignorance.

Kathleen blamed her incarceration on the absence of anyone to verify her version of events. Everyone involved was dead except for her. Kathleen claimed she initially received a woman and her infant, secreting them into the house. Shortly thereafter, a young student appeared in search of refuge and Kathleen placed her in a concealed spot outside but along the side of the home. The Interahamwe soon arrived, apparently in pursuit of the woman and her infant, and searched the home after beating Kathleen with a machete.

When they couldn't find anyone at my house, they decided to take the cow that I had, thinking that I would give in and tell them about the person. So they took the cow and slaughtered it. After eating the cow, they came back and said, "We know you are hiding someone here," and they decided to search around the house and even in the gardens around the house. ${ }^{78}$

This time, the Interahamwe discovered the mother and her infant hidden in the house and brought her outside. Here, Kathleen's story took an unexpected turn. The Interahamwe decided not only to let the woman and child live, but entrusted them into the care of Kathleen, threatening her if she did not care for them. Kathleen continued without pause,

So I got the woman and took her inside the house and went outside to cook porridge for her and the baby. So meanwhile, I'm cooking, [and] the woman got the baby and threw the baby in the latrine, in the toilet. ${ }^{79}$

According to Kathleen, even though the woman and child were now safely in her care and with the blessing of the Interahamwe, the mother decided to murder her baby.

She told me, "The reason why I did that is I'm scared of her crying when I'm in hiding and even people trying to hide me - her crying would make 
people find me where I'm hiding, that's why I decided to throw her away." And this was her firstborn. She said, "If I survive, I will be able to give birth to other children." 80

Kathleen explained that because the woman had killed her infant, she, Kathleen, turned the woman out of her home and sent her to her parents. She was murdered shortly thereafter. When the genocide ended, Kathleen was jailed, but not for the murder of the woman. She was suspected and later found guilty of murdering the infant. After nine years in prison, Kathleen decided to beg forgiveness but stopped short of accepting direct complicity in the killing,

I accepted that in a way, I should have stopped her from killing the baby which I didn't do - and I decided to ask for forgiveness for that. Because I didn't stop her from killing the baby and also, there is no evidence now because she also died. So they think I came up with all this because the kid is not there to prove that I was trying to save her... I believe I participated in a way. ${ }^{81}$

Sylvia insisted she was wrongly accused of the murder of a person near her home. She evaded details about the death and the accusation against her. She acknowledged in general terms to have been accused by the Inkotanyi (RPF forces) as well as by survivors at Gacaca. But despite testimonies to the contrary, she maintained her innocence. Still, she had accepted her crime in the Gacaca court and had begged forgiveness, declaring it was prophesized in a vision by members of her prayer group well before the genocide began.

While I even have [the right] to be angry about what happened, when we were praying before the war ... they used to have these visions that, "This [genocide] is going to happen and remember there will be those who are innocent who will be accused of what happened when they are innocent anyway. So you shouldn't be angry, you should prepare yourselves and when it happens, just embrace it." $\$ 2$

She accepted her incarceration as fulfillment of this prophetic vision, omitting her agency entirely, instead focusing on the hardships she experienced in TIG and overlooking the violence and carnage that took place during the genocide.

How are we to understand women's refusal to acknowledge their participation in the genocide? One possibility is that they are telling the truth and the Gacaca system is so flawed that the entire judicial process has been compromised. Although legal scholars critique the Gacaca courts for their procedures and outcomes and there have been reported instances of corruption on the part of the inyangamugayo, the system has by and large held up to international scrutiny. A more likely possibility is that respondents worried that what they said to me could be used by Gacaca or the government. Despite assurances that these interviews were confidential, some women may have altered their narrative out of 


\section{Perpetrators}

fear that their testimony could be deployed against them in court or would undermine an appeal in process. Other women emphasized their suffering and victimhood and asked me for gifts like Bibles, Vaseline, or money to visit their families. ${ }^{83}$ The women may have feared that admitting to or describing their crimes would diminish their likelihood of success. Deena asked me directly, "The information I have given you, how is it going to help my kids, me, in terms of is it going to help in a way of reviewing my case or how is it going to help them?"84 Deena's question came at the end of the interview and indicated parallel intentions that likely influenced her account: to use her testimony as evidence in her pending appeal case before Gacaca (which asserted her innocence) and to gain monetary or material benefits for her family.

The reticence and outright deception of women perpetrators contrasted sharply with the men perpetrator testimonies housed at the Genocide Archive of Rwanda, ${ }^{85}$ and the interviews conducted by others, including political scientist Scott Straus and journalist Jean Hatzfeld (both of whom focused on men perpetrators). But why did the majority of women perpetrators deny their crimes? And why were they noticeably more reluctant then men perpetrators of the same genocide? Perhaps women diminish their role in the genocide because of traditional interpretations of women's participation in violence. Even during times of war and chaos - when Cynthia Enloe notes that policymakers "who believe in the naturalness and rightness of a patriarchal social order nonetheless will violate conventional tenets of masculine and feminine difference so that they can use women in new, 'nontraditional' ways for the sake of bolstering their war-waging efforts" and mobilized women. Pio, an incarcerated perpetrator interviewed by Hatzfeld, recounted that, "There were even healthy men who sent their wives to replace them for a day on the expeditions, but that didn't happen often because it was not legitimate." ${ }^{\prime 87}$ Women's participation in specific, direct acts of genocide, despite deliberate efforts to militarize and mobilize women to join perpetration efforts, was considered unacceptable. This perceived unseemliness may have in turn influenced narratives of the genocide in Rwanda and the role of women perpetrators, even among the very women incarcerated for genocide-related crimes.

Pio's assessment was not an anomaly. His observation echoes perceptions and reactions provided by interviewed government stakeholders, community stakeholders, witnesses, and perpetrators. Genocide survivor and peace scholar Ezechial Sentama remembered seeing women perpetrate crimes during the genocide and reasoned,

Women, I could say that they forgot their role as far as the Rwandan culture is, but actually the role, the role of women we know. A woman is a mother. She is somebody who seems to have much more compassion than men, you know. So they forgot their role of women. ${ }^{88}$

Omar Ndiyeze, a genocide survivor and then second vice-coordinator for AERG, a student genocide survivors' organization, understood the anonymity of women 
perpetrators as a result of gendered perceptions of women and in spite of direct knowledge of their participation.

Most of the truth from women we don't know. We don't discover all the truth about the participation of women because you see, we saw that the women used to scream to show the Interahamwe where the Tutsis are hiding, to go where the Interahamwe had finished killing people and then take the property off of the dead people. This phenomena [of women participating], you can't have someone to testify about it, even in Gacaca.... The genocide, it's not something easy to understand.$^{89}$

Emmanuel Nshimyimana elaborated further. He survived the genocide and went on to work for the Kigali Genocide Memorial. While on site at Murambi Genocide Memorial, he concluded,

Normally in Rwanda we are used to see men doing bad things like killing or fighting and other things. In our culture, women are the people who are, who are peaceful, who respect the people, the things. Actually it's very strange to hear about women participating in the period..$^{90}$

Holocaust survivor and author Primo Levi noted that "things whose existence is not morally comprehensible cannot exist."91 Far from being clichés, gendered assumptions about the sacredness of motherhood and women's passivity are still real in their function and application in Rwandan society, despite the country's current success in the area of gender mainstreaming and equality. Even today, and especially in rural areas, when a woman has children, she is referred to as "Mama $<$ Name of Baby $>$." This is one of many cultural practices when it comes to names but specific to mothers; it is considered disrespectful to call her by her first name because of her enhanced status as a mother, directly linking her maternity to her social standing and, with it, perceived norms about her character and behavior. Notwithstanding the historical fact that women were openly and deliberately mobilized to perpetrate genocide, and in spite of Rwanda's social advances, the populace continues to struggle to develop the critical imagination needed to see women's participation as actual and as instrumental to the perpetration of genocide in 1994. It may be that women perpetrators also struggle to address their role during the genocide and as a result are reticent to detail their participation. Thus, they elide their crimes along with any discussion of how women's participation in genocide contradicts societal norms. The women are hardly attempting to change the narrative by coming forward. And why would they? With that voluntary obscurity comes a pervasive anonymity that persists even today.

It is difficult to normalize women perpetrators and avoid the pitfall of categorizing women perpetrators according to Sjoberg and Gentry's "mother, monster, whore" paradigm, ${ }^{92}$ casting them as freak anomalies and citing instances of highlevel perpetration, like that of Pauline Nyiramasuhuko, in dehumanizing terms in order re-enforce the construct of women as peace-loving pacifists. Yet, as we 


\section{Perpetrators}

have seen, women perpetrators were not rare. Indeed, the people we have discussed illustrate women's capacity to perpetrate genocide. Falling into gendered mental ruts that ignore women's perpetration costs us the opportunity to examine and fully grasp what half of the Hutu population was doing during the genocide. It thus renders them invisible when exploring post-genocide realities.

These mental ruts are both external to the country - affecting those documenting and discussing the genocide in Rwanda from outside of Rwanda - and internal - within the mainstream narrative. Within Rwanda, we must ask why and how the mainstream narrative does not include accounts of womenperpetrated genocide crimes, especially when trials reveal their participation.

Another explanation for women's reticence to describe their crimes has more nefarious implications: The women denied their crimes, gave faulty confessions, and feigned contrition because they are not sorry and are not rehabilitated. ${ }^{93}$

\section{Remorse}

As my interviews progressed, a formula emerged: The less forthcoming the woman perpetrator, the less remorse she expressed and the more she emphasized personal suffering and loss. Alexa was incarcerated for abandoning a boy she had agreed to rescue. After attempting to save a three-year-old girl and then, fearing discovery, giving her back to her mother, she decided to aid a 13-yearold boy. This time, Alexa made sure to hide her complicity in the rescue, sending the boy down one path while she took another, promising to meet him at a prearranged destination. She claimed the boy was already dead when she arrived. Alexa's role in his rescue and death were difficult to determine. She dodged direct questions, focusing instead on her powerlessness.

There were times when you wanted to do something but because you didn't have a choice and you couldn't help someone who was being killed, so you would just look. Not because you didn't want to help, but because you couldn't do anything at that moment. ${ }^{94}$

In the end, she was reluctant to express remorse, again denying her agency and couching her regret in religious fatalistic terms. "I embrace the fact that I'm here because I believe it was God's will, whatever happened to this kid." 95

Tracy also denied complicity in the genocide, convinced she was incarcerated because of an inter-family land dispute and not because of the genocide. While witnesses claimed she called out in order to draw the Interahamwe to Tutsis in hiding, she insisted she had merely called to her child to lock the door because she saw the militia killers approaching. Referring to her situation as the "devil's trap," she focused on the consequences of her incarceration and lamented the fact that her youngest daughter was home alone, without anyone to care for her. And her husband was serving a 20 -year prison sentence for raping a mentally disabled young woman, a charge she asserted was also false. Ending her narrative, she returned to her incarceration and surmised that, "I wasn't around, 
that's why my husband had all those problems. If I had been there, he wouldn't be in jail right now." 96

Lucy was unique in that she denied her crimes but still articulated regret. While Lucy refused to accept responsibility for revealing the Tutsis hidden in her family's banana plantation to the killers, she did express remorse over their deaths. Her focus was not on her own hardships. Only later, when asked what she would do should someone try to incite hatred or start another genocide, did she refer to her suffering or that of her children. The reason she did not want segregation or violence was because the genocide had resulted in her incarceration. Orphaned at a young age, she did not wish for her children to experience a similar fate. "When I think of how I grew up as an orphan ... and now I'm here. I can't even take care of my kids." 97

Sally focused on semantics when it came to her crimes and her regret. She was found guilty, she said, of exposing her Tutsi neighbor to the Interahamwe militias. But, she protested, "I didn't do it." Yet, at another point, she explained that yes, she did do it and, "that's why I reported myself, because they considered everyone who was there to have participated in a way and I accept that I alarmed [alerted the militia]." 98 In the end, Sally was ambiguous about whether or not her guilt was a result of being present when her neighbor was killed or sounding the alarm that resulted in her neighbor's murder. Throughout the interview, she referred to both scenarios. When asked if she felt regret for her actions, her initial response was, "I do regret because if I didn't stand there and alarm, I wouldn't be here," emphasizing her personal suffering. When asked, "Do you regret that the person died, too?" she confirmed regret for the death of her neighbor but emphasized her own loss, closing with, "And I'm here." 99

Kristen too emphasized her own hardships. When asked if she regretted her actions, she was resolute, "So much. So much, I think I will never even think of going anywhere like this [TIG camp]." When asked what specifically she regretted, she grew emotional. "I regret because the outcome of having gone there [to the river] wasn't the best for me. I really had a bad experience." She paused to dry her eyes and then continued.

Because you see my three kids I told you, all of them, they don't have grandparents, they don't have any family members, so people from outside are the ones just helping to take care of the kids. And also where we used to stay, because I'm not there, it's more like a bush now. The place is not - it's like a deserted house. And there is no way - their way of living is not the best, it's not good. ${ }^{100}$

Again and again, the perpetrators described at length the hardships they endured and the regret they experience as a result of their own suffering, not as a result of the genocide or their role in its perpetration.

In Rwanda and abroad, the role of women perpetrators during the 1994 genocide remains a white spot and thus there is no discussion of how their participation contradicts societal norms. It is important to ask why it is difficult to 


\section{Perpetrators}

imagine women as participants in a society-wide phenomenon such as genocide. Instead of expressing skepticism about a woman's ability to participate in genocide, a more important question is why would women not be participants? Although their participation is obscured, overlooked, or outright denied due to gendered norms that skew the mainstream narrative, women played an active role in the perpetration of the genocide in Rwanda.

\section{Notes}

1 Interview G 12 "Kristen," interview by Sara. E. Brown, Ngororero, Rwanda, 21 February 2014.

2 Hollie Nyseth Brehm, Christopher Uggen, and Jean-Damascène Gasanabo, "Genocide, Justice, and Rwanda's Gacaca Courts," Journal of Contemporary Criminal Justice 30, no. 3 (2014): 335.

3 Sigall Horovitz, "Rwanda: International and National Responses to the Mass Atrocities and Their Interaction," DOMAC 6 (2010): 21-2.

4 These goals were previously available on the Inkiko Gacaca website which has since been shut down by the Rwandan government: www.inkiko-gacaca.gov.rw/En.

5 The original four categories, stipulated in Article 51 (pages 17-18) of "Organic Law No 40/2000 of 26/01/2001 Setting Up 'Gacaca Jurisdiction' and Organizing Prosecutions for Offences Constituting the Crime of Genocide or Crimes Against Humanity Committed Between October 1, 1990 and December 31, 1994" were defined as follows:

Category 1: a) The person whose criminal acts or criminal participation place among planners, organisers, incitators [sic], supervisors of the crime of genocide or crime against humanity; b) The person who, acting in a position of authority at the national, provincial or district level, within political parties, army, religious denominations or militia, has committed these offences or encouraged others to commit them; c) The well-known murderer who distinguished himself in the location where he lived or wherever he passed, because of zeal which has characterised him in killings or excessive wickedness with which they were carried out; d) The person who has committed rape or acts of torture against person's sexual parts.

Category 2: a) The person whose criminal acts or criminal participation place among authors, coauthors or accomplices of deliberate homicides or serious attacks against persons which caused death; b) The person who, with intention of giving death, has caused injuries or committed other serious violences, but from which the victims have not died.

Category 3: The person who has committed criminal acts or has become accomplice of serious attacks, without the intention of causing death to victims.

Category 4: The person having committed offences against assets. However, the author of the mentioned offences who, on the date of this organic law enforcement, has agreed either with the victim, or before the public authority or in arbitration, for an amicable settlement, cannot be prosecuted for the same facts.

6 Usta Kaitesi, Genocidal Gender and Sexual Violence: The Legacy of the ICTR, Rwanda's Ordinary Courts and Gacaca Courts (Cambridge: Intersentia Publishing, 2014): 64.

7 Ibid.: 206.

8 Reva N. Adler, Cyanne E. Loyle, and Judith Globerman. "A Calamity in the Neighborhood: Women's Participation in the Rwandan Genocide." Genocide Studies and Prevention 2, no. 3 (2007): 212. 
9 Rwanda Government, "Summary of the Report Presented at the Closing of Gacaca Courts Activities," (June 2012): 10.

10 Sociologist Hollie Nyseth Brehm is currently working with colleagues to develop a breakdown of the acquittal rates (pre- and post-appeals process) according to sex, reviewing both the cases as well as the individuals brought before the Gacaca courts.

11 Nyseth Brehm, Uggen, and Gasanabo, "Genocide, Justice, and Rwanda's Gacaca Courts": 340.

12 Rwanda Government. "Summary of the Report Presented at the Closing of Gacaca Courts Activities": 9.

13 A body of literature explores the militarization of women and their participation as combatants and armed insurgent. For example, see: For example, see: Carrie Hamilton, "The Gender Politics of Political Violence: Women Armed Activists in ETA," Feminist Review 86 (2007): 132-48; Ana Christina Ibanez, "El Salvador: War and Untold Stories - Women Guerillas." In Victims, Perpetrators, or Actors? edited by Caroline N. O. Moser and Fiona Clark (New York: Zed Books, 2001): 12-29; Keren Kampwirth, Women \& Guerrilla Movements: Nicaragua, El Salvador, Chiapas, Cuba (University Park: University of Pennsylvania Press, 2002); Megan MacKenzie, "Securitization and De-Securitization: Female Soldiers and the Reconstruction of Women in Post-Conflict Sierra Leone." In Gender and International Security, edited by Laura Sjoberg (New York: Routledge, 2010): 24-37; Sandra McEvoy's doctoral dissertation on women in the Loyalist paramilitary in Ireland; Dyan Mazurana and Susan McKay, "Where are the Girls? Girls in Fighting Forces in Northern Uganda, Sierra Leone, and Mozambique: Their Lives During and After War," Rights and Democracy (2004); Jan Jindy Pettman, Worlding Women (New York: Routledge, 1996); and Karen Turner, Even the Women Must Fight: Memories of War from North Vietnam (New York: John Wiley \& Sons, 1998).

14 The other two modified categories (First and Third) defined in Article 51 of "Organic Law No 40/2000 of 26/01/2001 Setting Up 'Gacaca Jurisdiction' and Organizing Prosecutions for Offences Constituting the Crime of Genocide or Crimes Against Humanity Committed Between October 1, 1990 and December 31, 1994" are as follows:

First Category: 1. Any person who committed or was an accomplice in the commission of an offence that puts him or her in the category of planners or organisers of the genocide or crimes against humanity; 2. Any person who was at a national leadership level and that of prefecture level: public administration, political parties, army, gendarmerie, religious denominations or in militia group, and committed crimes of genocide or crimes against humanity or encouraged others to participate in such crimes, together with his or her accomplice; 3 . Any person who committed or was an accomplice in the commission of an offence that puts him or her among the category of people who incited, supervised and ringleaders of the genocide or crimes against humanity; 4. Any person who was the leadership level at the Sub-Prefecture and Commune: public administration, political parties, army, gendarmerie, communal police, religious denominations or in militia, who committed any crimes of genocide or other crimes against humanity or encouraged others to commit similar offences, together with his or her accomplice; 5. Any person who committed the offence of rape or sexual torture, together with his or her accomplice.

Third Category: A person who only committed an offence related to property. However, when the offender and the victim come to a settlement by themselves, settle the matter before the authorities or before the witnesses before the commencement of this law, the offender shall not be prosecuted.

15 While I do not recommend reading Rusesabagina's memoirs as a factual account, those interested in learning more can see: Paul Rusesabagina with Tom Zoellner, 


\section{Perpetrators}

An Ordinary Man: An Autobiography (New York: Viking, 2006). For a survivor's account of his experiences in the Hotel des Milles Collines, see Edouard Kayihura's Inside the Hotel Rwanda: The Surprising Story ... and why it Matters Today (Dallas: Benbella Books, 2014).

16 Dieudonné Gakire, A Dreaming Child (Kigali: NPD Cotraco, 2014): 24.

17 Johan Galtung, "Violence, Peace, and Peace Research," Journal of Peace Research 6, no. 3 (1969): 169.

18 Interview Odette Kayirere and Sabine Uwasi, interview by Sara E. Brown, Kigali, Rwanda, 15 June 2011.

19 Interview Omar Ndiyeze and Richard Rugira, interview by Sara E. Brown, Kigali, Rwanda, 15 June 2011.

20 Africa Rights, Rwanda: Not So Innocent - When Women Become Killers (London: Africa Rights, 1995): 2.

21 Interview Odeth Kantengwa, interview by Sara E. Brown, Kigali, Rwanda, 16 June 2011.

22 For more on my methodology, see Chapter 1, "Finding the Right Flashlight," and appendices.

23 Interview G 2 "Suzanne," interview by Sara E. Brown, Muhanga, Rwanda, 30 June 2011.

24 Saul Friedlander, Memory, History, and the Extermination of the Jews of Europe (Indianapolis: Indiana University Press, 1993): 130.

25 Carol Cohn, "Motives and Methods: Using Multi-Cited Ethnography to Study National Security Discourses." In True Feminist Methodologies for International Relations, edited by Brooke Ackerly, Maria Stern, and Jacqui True (New York: Cambridge University Press, 2006): 106.

26 Interview G 2 "Suzanne."

27 Interview S 5 "Nathan," interview by Sara E. Brown, Kigali, Rwanda, 12 February 2014.

28 Ibid.

29 Ibid.

30 Interview Janvier Forongo, interview by Sara E. Brown, Kigali, Rwanda, 14 June 2011.

31 Ruth Seifert, "War and Rape: A Preliminary Analysis." In Mass Rape: The War Against Women in Bosnia-Herzegovina, edited by Alexandra Stiglmayer (Lincoln: University of Nebraska Press, 1994): 55.

32 Ibid.

33 Inger Skjelsbæk, "Sexual Violence in the Post-Yugoslav." In Women and War: Power and Protection in the 21st Century, edited by Kathleen Kuehnast, Chantal de Jonge Oudraat, and Helga Hernes (Washington, DC: United States Institute of Peace Press, 2011): 82.

34 Interview S 2 "Charles," interview by Sara E. Brown, Kigali, Rwanda, 29 June 2011.

35 Will Storr, "The Rape of Men: The Darkest Secret of War," Guardian, 16 July 2011. www.theguardian.com/society/2011/jul/17/the-rape-of-men?CMP=share_btn_fb.

36 Interview S 2 "Charles."

37 Ibid.

38 Interview G 6 “Agnes," interview by Sara E. Brown, Muhanga, Rwanda, 30 June 2011.

39 Interview G 18 "Cindy," interview by Sara E. Brown, Jali, Rwanda, 16 February 2014.

40 See International Criminal Tribunal for Rwanda, "Judgement and Sentence: The Prosecutor v. Pauline Nyiramasuhuko et al. Case No. ICTR-98-42-T," 24 June 2011. www.unictr.org/sites/unictr.org/files/case-documents/ictr-98-42/trial-judgements/en/ 110624.pdf. 
41 Mark A. Drumbl, "She Makes Me Ashamed to Be a Woman: The Genocide Conviction of Pauline Nyiramasuhuko, 2011." Michigan Journal of International Law 34, no. 3 (2013): 583.

42 See Chapter 3, "Mobilization and Militarization."

43 Alison Des Forges, Leave None to Tell the Story: Genocide in Rwanda (New York: Human Rights Watch, 1999): 67. A body of scholarship deals with Nazi propaganda. While much of Nazi propaganda was intended to promote the cult ideology of the Nazi party, radio - alongside print and film - played instrumental roles in sensitizing the German populace toward violence and mobilizing many to participate in genocide.

44 Interview Valerie Bemeriki.

45 Ibid.

46 Ibid.

47 Des Forges: 678. For a detailed account of Bemeriki's radio transmissions, refer to the section on her crimes in Rwanda: Not So Innocent: 149-53.

48 Interview Valerie Bemeriki.

49 Ibid.

50 Ibid.

51 Interview G 2 "Suzanne."

52 Interview G 22 "Vanessa," interview by Sara E. Brown, Cyungo, Rwanda, 17 March 2014.

53 Interview G 5 "Rose," interview by Sara E. Brown, Muhanga, Rwanda, 30 June 2011.

54 Interview G 8 "Cassie," interview by Sara E. Brown, Ngoma, Rwanda, 14 February 2014.

55 Interview G 25 "Tracy," interview by Sara E. Brown, Rwamagana, Rwanda, 29 April 2014.

56 Interview G 13 "Elaine," interview by Sara E. Brown, Ngororero, Rwanda, 21 February 2014.

57 As we see in Chapter 4, "Rescuers."

58 Interview G 4 "Jennifer," interview by Sara E. Brown, Muhanga District, Rwanda, 30 June 2011.

59 Ibid.

60 Interview G 13 "Elaine."

61 Interview G 5 "Rose."

62 Ibid.

63 Interview G 11 "Tanya," interview by Sara E. Brown, Ngoma, Rwanda, 14 February 2014.

64 Ibid.

65 Ibid.

66 Ibid.

67 Interview G 7 “Amy,” interview by Sara E. Brown, Bugesera, Rwanda, 3 February 2014.

68 Interview G 19 "Charlotte," interview by Sara E. Brown, Jali, Rwanda, 16 February 2014.

69 Ibid.

70 Jean Hatzfeld, Machete Season: The Killers in Rwanda Speak (New York: Farrar, Straus and Giroux, 2005): 112.

71 The twenty-sixth case was tried by the National Courts as a Category 1 crime and was thus not available for cross-reference at the Gacaca Court Archives.

72 Gacaca Court Archives, transcripts for G 12, retrieved April 2014 in Kigali, Rwanda.

73 Interview G 17 “Deena," interview by Sara E. Brown, Jali, Rwanda, 16 February 2014.

74 Ibid.

75 Interview G 16 "Laura," interview by Sara E. Brown, Jali, Rwanda, 16 February 2014.

76 Ibid. 


\section{Perpetrators}

77 Ibid.

78 Interview G 14 "Kathleen," interview by Sara E. Brown, Ngororero, Rwanda, 21 February 2014.

79 Ibid.

80 Ibid.

81 Ibid.

82 Interview G 21 "Sylvia," interview by Sara E. Brown, Cyungo, Rwanda, 13 March 2014.

83 The women requested Vaseline because it is commonly used by low income Rwandans as a moisturizer. The more affluent use cocoa butter or other imported moisturizers.

84 Interview G 17 "Deena."

85 Staff at the Genocide Archive of Rwanda, who were collecting testimonies all over the country, were baffled by the difficulties I described to them. Revisiting their collection of testimonies, I realized that the perpetrator testimony collection was, at that time, exclusively male.

86 Cynthia Enloe, Globalization and Militarism: Feminists Make the Link (New York: Rowman \& Littlefield Publishers, 2007): 81.

87 Hatzfeld: 73.

88 Interview Ezechial Sentama, interview by Sara E. Brown, Kigali, Rwanda, 25 June 2011.

89 Interview Omar Ndiyeze and Richard Rugira.

90 Interview Emmanuel Nshimyimana, interview by Sara E. Brown, Murambi, Rwanda, 28 June 2011.

91 Primo Levi, "Beyond Judgment," New York Review of Books, 17 December 1987: 14.

92 Laura Sjoberg and Caron Gentry, Mothers, Monsters, Whores: Women's Violence in Global Politics (London: Zed Books, 2007).

93 We shall explore that possibility in greater detail in the Chapter 6, "Post-Genocide Trajectories."

94 Interview G 20 "Alexa," interview by Sara E. Brown, Cyungo, Rwanda, 17 March 2014.

95 Ibid.

96 Interview G 25 "Tracy."

97 Interview G 3 "Lucy," interview by Sara E. Brown, Muhanga District, Rwanda, 30 June 2011.

98 Interview G 10 "Sally," interview by Sara E. Brown, Ngoma, Rwanda, 14 February 2014.

99 Ibid.

100 Interview G 12 "Kristen."

\section{References}

Adler, Reva N., Cyanne E. Loyle, and Judith Globerman. "A Calamity in the Neighborhood: Women's Participation in the Rwandan Genocide." Genocide Studies and Prevention 2 , no. 3 (2007): 209-33.

African Rights. Rwanda: Not So Innocent - When Women Become Killers (London: African Rights, 1995).

Cohn, Carol. "Motives and Methods: Using Multi-Cited Ethnography to Study National Security Discourses." In True Feminist Methodologies for International Relations, edited by Brooke Ackerly, Maria Stern, and Jacqui True, 91-107 (New York: Cambridge University Press, 2006). 
Des Forges, Alison. Leave None to Tell the Story: Genocide in Rwanda (New York: Human Rights Watch, 1999).

Drumbl, Mark A. "She Makes Me Ashamed to Be a Woman: The Genocide Conviction of Pauline Nyiramasuhuko, 2011." Michigan Journal of International Law 34, no. 3 (2013): 559-603.

Enloe, Cynthia. Globalization and Militarism: Feminists Make the Link (New York: Rowman \& Littlefield Publishers, 2007).

Friedlander, Saul. Memory, History, and the Extermination of the Jews of Europe (Indianapolis: Indiana University Press, 1993).

Gacaca Court Archives. Transcripts for G 12. Retrieved April 2014 in Kigali, Rwanda.

Gakire, Dieudonné. A Dreaming Child (Kigali: NPD Cotraco, 2014).

Galtung, Johan. "Violence, Peace, and Peace Research." Journal of Peace Research 6, no. 3 (1969): 167-91.

Hatzfeld, Jean. Machete Season: The Killers in Rwanda Speak (New York: Farrar, Straus and Giroux, 2005).

Horovitz, Sigall. "Rwanda: International and National Responses to the Mass Atrocities and Their Interaction." DOMAC 6 (2010).

International Criminal Tribunal for Rwanda. "Judgement and Sentence: The Prosecutor v. Pauline Nyiramasuhuko et al. Case No. ICTR-98-42-T" 24 June 2011. www.unictr. org/sites/unictr.org/files/case-documents/ictr-98-42/trial-judgements/en/110624.pdf

Interview Emmanuel Nshimyimana. Interview by Sara E. Brown. Murambi, Rwanda, 28 June 2011.

Interview Ezechial Sentama. Interview by Sara E. Brown. Kigali, Rwanda, 25 June 2011. Interview G 2 "Suzanne.” Interview by Sara E. Brown. Muhanga, Rwanda, 30 June 2011. Interview G 3 "Lucy." Interview by Sara E. Brown. Muhanga District, Rwanda, 30 June 2011.

Interview G 4 "Jennifer." Interview by Sara E. Brown. Muhanga District, Rwanda, 30 June 2011.

Interview G 5 “Rose.” Interview by Sara E. Brown. Muhanga, Rwanda, 30 June 2011. Interview G 6 “Agnes.” Interview by Sara E. Brown. Muhanga, Rwanda, 30 June 2011. Interview G 7 “Amy.” Interview by Sara E. Brown. Bugesera, Rwanda, 3 February 2014. Interview G 8 "Cassie." Interview by Sara E. Brown. Ngoma, Rwanda, 14 February 2014.

Interview G 10 "Sally." Interview by Sara E. Brown. Ngoma, Rwanda, 14 February 2014. Interview G 11 "Tanya." Interview by Sara E. Brown. Ngoma, Rwanda, 14 February 2014.

Interview G 12 “Kristen.” Interview by Sara. E. Brown. Ngororero, Rwanda, 21 February 2014.

Interview G 13 "Elaine.” Interview by Sara E. Brown. Ngororero, Rwanda, 21 February 2014.

Interview G 14 “Kathleen.” Interview by Sara E. Brown. Ngororero, Rwanda, 21 February 2014.

Interview G 16 "Laura." Interview by Sara E. Brown. Jali, Rwanda, 16 February 2014. Interview G 17 “Deena.” Interview by Sara E. Brown. Jali, Rwanda, 16 February 2014. Interview G 18 "Cindy." Interview by Sara E. Brown. Jali, Rwanda, 16 February 2014. Interview G 19 "Charlotte." Interview by Sara E. Brown. Jali, Rwanda, 16 February 2014.

Interview G 20 “Alexa.” Interview by Sara E. Brown. Cyungo, Rwanda, 17 March 2014. Interview G 21 “Sylvia.” Interview by Sara E. Brown. Cyungo, Rwanda, 13 March 2014. 
Interview G 22 "Vanessa." Interview by Sara E. Brown. Cyungo, Rwanda, 17 March 2014.

Interview G 25 "Tracy." Interview by Sara E. Brown. Rwamagana, Rwanda, 29 April 2014.

Interview Janvier Forongo. Interview by Sara E. Brown. Kigali, Rwanda, 14 June 2011. Interview Odeth Kantengwa. Interview by Sara E. Brown. Kigali, Rwanda, 16 June 2011. Interview Odette Kayirere and Sabine Uwasi. Interview by Sara E. Brown. Kigali, Rwanda, 15 June 2011.

Interview Omar Ndiyeze and Richard Rugira. Interview by Sara E. Brown. Kigali, Rwanda, 15 June 2011.

Interview S 2 “Charles.” Interview by Sara E. Brown. Kigali, Rwanda, 29 June 2011.

Interview S 5 "Nathan." Interview by Sara E. Brown. Kigali, Rwanda, 12 February 2014.

Interview Valerie Bemeriki, interview by Sara E. Brown, Kigali, Rwanda, 26 March 2014.

Kaitesi, Usta. Genocidal Gender and Sexual Violence: The Legacy of the ICTR, Rwanda's Ordinary Courts and Gacaca Courts (Cambridge: Intersentia Publishing, 2014).

Levi, Primo. "Beyond Judgment." New York Review of Books, 17 December 1987.

Nyseth Brehm, Hollie, Christopher Uggen, and Jean-Damascène Gasanabo. "Genocide, Justice, and Rwanda's Gacaca Courts." Journal of Contemporary Criminal Justice 30, no. 3 (2014): 333-52.

Rwanda Government. "Organic Law No 40/2000 of 26/01/2001 Setting Up 'Gacaca Jurisdiction' and Organizing Prosecutions for Offences Constituting the Crime of Genocide or Crimes Against Humanity Committed Between October 1, 1990 and December 31, 1994." (26 January 2001, modified 2008).

Rwanda Government. "Summary of the Report Presented at the Closing of Gacaca Courts Activities." (June 2012).

Seifert, Ruth. "War and Rape: A Preliminary Analysis." In Mass Rape: The War Against Women in Bosnia-Herzegovina, edited by Alexandra Stiglmayer (Lincoln: University of Nebraska Press, 1994): 54-72.

Skjelsbæk, Inger. "Sexual Violence in the Post-Yugoslav Wars." In Women and War: Power and Protection in the 21st Century, edited by Kathleen Kuehnast, Chantal de Jonge Oudraat, and Helga Hernes (Washington, DC: United States Institute of Peace Press, 2011).

Sjoberg, Laura, and Caron Gentry. Mothers, Monsters, Whores: Women's Violence in Global Politics (London: Zed Books, 2007).

Storr, Will. "The Rape of Men: The Darkest Secret of War.” The Guardian. 16 July 2011. www.theguardian.com/society/2011/jul/17/the-rape-of-men?CMP=share_btn_fb. 


\section{Post-Genocide Trajectories}

In 1995, Rwandan national Beatrice Munyenyezi, then living in Nairobi, Kenya, with her three small children, requested asylum in the United States. Granted refugee status in 1998, she was relocated to New Hampshire. With the exception of filing for bankruptcy in 2008, Munyenyezi's experiences were typical of a resettled refugee: she learned English, found a job, enrolled in college classes, and watched her daughters grow up. Life was normal. Then, in February 2013, after a five-year federal investigation and two trials, she was found guilty of procuring U.S. citizenship illegally and lying to U.S. officials about her role in the genocide in Rwanda and in the political infrastructure responsible for the genocide.

The first trial went awry from the beginning. The prosecution asserted in opening arguments that, in contrast to the victim Munyenyezi claimed to be, she led Interahamwe killing militias, selected and imprisoned women to be raped, and ordered the murder of countless victims. Sitting in the courtroom, I observed that rather than directly challenge these accusations, Munyenyezi's defense asserted that, as a woman and a then-pregnant mother, Munyenyezi was incapable of committing mass murder. In their opening statement and throughout the trial, the defense relied upon a patriarchal interpretation of genocide, contending that women and mothers do not victimize others, do not loot or steal, and certainly do not kill. The defense did not offer moral or religion-based compunctions or allude to moderate thinking on the part of their client. They relied on essentializing myths about women, as explained by feminist scholars Sjoberg and Gentry, which "include those that define what women are (pure, peaceful, etc.) but can also include those that define what women cannot be (perpetrators of genocide)." Using Munyenyezi's sex and motherhood to argue her inability to perpetrate genocide, her lawyers went beyond painting her into the background of the horrific events that ravaged Rwanda in 1994; they erased her from the picture entirely.

Throughout the proceedings, Munyenyezi, the daughter-in-law of Pauline Nyiramasuhuko and wife of Arsène Shalom Ntahobali, two of the most infamous perpetrators of the genocide in Rwanda, sat in silence, a stark contrast to the woman described by victims and perpetrators alike as full of vicious agency. She played her part well; when the jury was absent, she appeared nervous but 
buoyant, her back straight and her eyes clear. When the jury entered the room, her countenance changed. She hunched her shoulders, clutched a tissue, and kept her eyes downcast. In the end, the defense's strategy was effective: the jury was unable to determine her guilt or innocence, resulting in a mistrial.

Charged anew, Munyenyezi was brought back to court the next year. On the heels of the conviction of Prudence Kantengwa, Munyenyezi's sister who was also charged with immigration fraud, ${ }^{2}$ the prosecution changed tactics and adopted a new approach at Munyenyezi's second trial. The charges were the same: "two counts of procuring citizenship illegally by making false statements to the government." 3 But the emphasis shifted from her active participation in the perpetration of genocide to her repeated deception on federal forms and to federal officials. The prosecutors did not try to prove that she had committed crimes during the genocide. Instead, they focused on inconsistencies in her immigration paperwork, emphasizing that time and again she lied in response to questions specifically designed by the U.S. Department of State to identify (and reject) any person who, through political affiliation with the genocidal government or direct participation, was complicit in the 1994 genocide. While the first jury was reticent to acknowledge Munyenyezi's capacity to staff a notoriously violent checkpoint outside her home or shoot a nun in the head, the second jury readily accepted her capacity to lie. In February 2013, more than 14 years after she had moved to the U.S. and begun a new life, Munyenyezi was sentenced to two consecutive 120-month prison sentences and stripped of her U.S. citizenship.

On the other side of the world, Rwanda followed the U.S. legal proceedings against Munyenyezi, but coverage of the second trial was overshadowed by political discussions in advance of the 2013 election. A few months later, in September, millions of Rwandans queued at local polling stations to cast their vote and elected 51 women to Rwanda's Lower House of Parliament, 64 percent of the available 80 seats. Hailed as unprecedented and remarkable by international media, Rwandans appeared unfazed, or at the very least unsurprised, by the election results. The highest percentage of women in any parliament worldwide, this victory was welcomed as the anticipated product of the country's post-genocide gender mainstreaming policies. Rwanda had already made headlines in 2008, achieving an international benchmark when it became the first country in the world to elect a majority-women parliament (at 56 percent), including the speaker's chair. Many viewed the 2013 election as merely a continuation of the gender-inclusive transition that had begun in the aftermath of the genocide.

Clearly, women's roles had begun to shift in Rwanda, following an international trend observed by legal scholar Kelly D. Askin. "Women are increasingly recognized as actors, enablers, and even perpetrators, instead of simply as victims of wartime violence," Askin noted. "As more women participate as combatants and government officials, women are being accused of responsibility for war crimes, crimes against humanity, and genocide." Still, despite the electoral results, and notwithstanding widespread acknowledgement of the participation by individual women such as Beatrice Munyenyezi in the genocide, the role of 
women as a broader category of participants of the genocide remains largely ignored in Rwanda and unacknowledged by the international community.

At the same time, women rescuers continue to be obscured by the existing supra-narrative of the genocide. Although a few women have gained recognition nationally and abroad, most went unacknowledged after the genocide. And for myriad reasons, few sought notice. ${ }^{5}$ Indeed, whatever recognition women rescuers gained was local and often negative. Some were celebrated by the people they rescued; others were targeted as collaborators by remaining perpetrators in their area.

For women rescuers and perpetrators, the post-genocide trajectories shaped by this relative anonymity are uniquely gendered. Anonymity for many women began as soon as the genocide ended when efforts to rebuild, rehabilitate, and reconstruct the country did not sufficiently take these women into account. When the Rwandan Patriotic Front (RPF) conquered the capital city of Kigali in July 1994, it faced seemingly insurmountable challenges. Labeled the "fastest genocide in modern history," loss of life was compounded by the flight of another two million people (the majority of whom were Hutu) to neighboring countries. In total, Rwanda lost nearly 40 percent of its population in just three months. The country was physically destroyed and its landscape bore evidence of the "scorched earth" policies of the FAR and Interahamwe. "The capital city, Kigali, was left in ruin," a 1995 U.S. Institute of Peace report declared. "Of the 350,000 inhabitants before the war, only 40,000 to 50,000 remained. There was no running water, no electricity, no government infrastructure, and nearly every building was damaged." Aloisea Inyumba, founding member of the RPF, former Minister of Gender and Social Affairs, Senator, and first Minister for Gender and Family Promotion (MIGEPROF), recalled the destruction following the genocide. "The country was completely broken: the social, the cultural, everything was completely broken."7

The RPF worked quickly, establishing a "National Unity" power-sharing government, formed in accordance with the 1993 Arusha Accords agreement. Rose Kabuye, then a major in the RPF, was appointed mayor of Kigali and charged with rebuilding the city despite the absence of a municipal budget. The RPF militia-turned-national-military patrolled the country, combating insecurity and violence within and beyond its borders as genocidal violence continued in some parts of Rwanda, and the FAR and Interahamwe led attacks along its border with the Democratic Republic of the Congo. Genocide perpetrators who had not fled to Congo and elsewhere were rounded up and incarcerated in over-crowded, often-makeshift prisons throughout the country.

Many initiatives promoted by the government focused on inter-ethnic cooperation and were championed by women in high-level positions within the RPF. These included Inyumba's nationwide campaign to close the orphanages that had sprung up to house many of the 95,000-150,000 unaccompanied minors orphaned by the genocide. ${ }^{8}$ In an interview, Inyumba emphasized that the very success of the campaign relied upon Hutu and Tutsi women working together. "The fact that women, irrespective of their background, whether they are Hutus 
or Tutsis, were willing and were going to respond to children [meant that] we managed to close 80 orphanage centers." Other inter-ethnic women's groups were formed, including the women's rights organization, National Women Council (NWC) and the non-partisan Rwanda Women Parliamentarian Forum, and the work of Pro Femme Twese Hamwe, founded before the genocide, resumed.

The RPF consciously promoted the women in its ranks and included them in decision-making processes, and these women went on to spearhead peace, democracy, and women's rights throughout Rwanda. ${ }^{10}$ Their attempts met with some success. Women in leadership positions quickly reached out to women on the grassroots level to organize, empower, and mentor women, promoting reconciliation and peace through women's collaboration throughout Rwanda. The ripple effects of this empowerment spread slowly, however, and in some parts of the country were not felt at all. Throughout the planning processes, women rescuers and perpetrators were barely visible on the margins of the RPF's grand vision for Rwanda.

Overlooked on a national level, some women gained visibility and recognition on the local level. In communities across the country, women rescuers and perpetrators were often known but rarely received direct or official recognition. It is possible their agency constituted an example of "uncomfortable knowledge" that becomes, according to sociologist Stanley Cohen, an "open secret: known by all, but knowingly not known." ${ }^{11}$ In the odd instance when the local transcended the national, and community reactions to women perpetrators or rescuers were overt and publicized, the government took action. Still, for the most part, the women quietly resumed their day-to-day lives.

The international community shared this gendered blindspot. In the immediate post-genocide period (mid-1994-95), emergency humanitarian assistance was largely directed to relief efforts in the refugee camps in neighboring countries. Disproportionately less went to the survivors of the genocide within Rwanda. In 1996, a United States Agency for International Development (USAID) report found that,

Of the more than US\$2 billion spent on the Rwandan crisis since April 1994, the vastly larger share has gone to maintenance of refugees in Zaire, Tanzania, and Burundi. Although such a disproportionate allocation is understandable - refugees must be supported - it appears to Rwandans who have lived through the horror of genocide that the international community is more concerned about the refugees than the survivors. ${ }^{12}$

Following a re-evaluation of the humanitarian relief efforts in 1996, funding priorities began to shift to the internal needs in Rwanda, including reconstruction, rehabilitation, and development assistance. ${ }^{13}$ But the effectiveness of this assistance was hindered by Rwanda's poverty, land-locked geography, unstable neighbors to the west (Democratic Republic of Congo) and south (Burundi), and limited natural resources. Still, international aid flooded in and focused on 
agricultural rehabilitation, roads and transportation, military aid, refugee aid, judicial reform, economic reform, health care and emergency aid, and rehabilitating education.

Funds were also allocated to assist women and girls, estimated by the USAID report to represent between 60-70 percent of the population in $1996 .{ }^{14}$ While the attention provided to women and girls during this period was necessary and addressed a gap in the existing aid regime, it also reinforced the narrative of women as agency-less victims of the genocide.

By some estimates, between a third and a half of all women in the most hard-hit areas are widows. Further, several thousand women were raped. During the initial stages of emergency assistance, women were not given special treatment as a group. Rather, it was assumed that they would benefit from the assistance provided to various sectors.... Over time, PVOs [private voluntary organizations] working in the community began to recognize the distinctive needs of women - widows, victims of violence, and heads of households. These organizations developed ad hoc initiatives to support communities in caring for the most vulnerable. ${ }^{15}$

Leaping from emergency to emergency, the international community and various aid agencies rarely paused to address a more complicated narrative of the genocide. They did not incorporate a more nuanced approach to women's participation in the genocide or expand their gendered paradigm to include roles apart from woman-as-victim or woman-as-bystander. Justice and recognition only came much later, and not to all women.

The emphasis on justice in post-genocide Rwanda (necessary at the time) overshadowed in-depth examination of acts of rescue during the genocide. Justice was viewed as a funding and manpower priority; identifying rescuers, less so. This resulted in a disparity in available research on women perpetrators and women rescuers. And within that justice-driven campaign, a gender gap is evident, with men comprising the majority of the suspects held on suspicion of genocide crimes. While Rwandan society was determined to include and empower women in the public sphere following the genocide, women perpetrators and, more notably, women rescuers remained conspicuously absent from the national discourse on genocide. Nor were women given much thought when developing post-genocide policies specific to perpetrator rehabilitation and reintegration or society-wide reconciliation.

\section{Punishment and justice}

Often, women perpetrators rejoined society and resumed their lives, work, and community as though they had committed no crime. They were overlooked by national and international actors with their post-genocide reconstruction and rehabilitation discourse, policies, and programs. Until the implementation of the Gacaca courts a decade later, women like Deena lived in relative anonymity. Her 
life returned to normal after the arrival of RPF troops in her area brought an end to the genocide. In appearance and manner, ${ }^{16}$ she comported herself as a guiltless bystander to the genocide that had just devastated the countryside. She did not flee from the RPF soldiers; she stayed at home and resumed the same routine that had occupied her days prior to the genocide. During the week, she farmed her land; on Sundays, she attended a nearby Pentecostal church. Widowed just before the genocide, she raised her children alone and described their childhood as happy. As time passed and her children grew into adults, Deena celebrated their weddings and welcomed grandchildren into her expanding family. "It was like normal life again. I wasn't scared, I was there until when this whole Gacaca case came up." 17

Many women perpetrators shared Deena's experience. As we have seen, ${ }^{18}$ in the decade following the genocide over 120,000 Rwandans suspected of taking part in the genocide were arrested and detained in prisons crowded to the bursting point. The majority of incarcerated suspects were men, with women constituting just 3.4 percent of the prison population. Between 2004 and 2012, however, the number of women suspected of genocide crimes increased from approximately 3,000 incarcerated to 96,653 who were brought to dock. What were those women doing between 1994 and 2004?

Kathleen was one of the first to be incarcerated on suspicion of genocide perpetration, before the establishment of the Gacaca courts. Implicated by local Interahamwe after they were arrested, she was accused of murdering an infant in her care. "When the war stopped [in 1994], they got me and took me to jail for nine years. ... By the time Gacaca started in 2003, I had served nine years and seven months." ${ }^{\text {19 }}$ Kathleen had been unable to blend into society and resume her daily routine and activities. She was held in prison, awaiting trial, while many women rejoined society and continued their lives with little to no pause. Kathleen was the only one of the 25 interviewed who was arrested at the end of the genocide. When the Gacaca courts began to hear cases, hers was one. She was convicted for murder and sentenced to an additional 12 years in prison and in TIG.

Sylvia's history is more typical. She was questioned by the RPF in 1994 but, unlike Kathleen, she did not face justice for over a decade. When the RPF arrived in her area, everyone began to flee the country. With young children in tow, Sylvia could not join them, and she and her children hid with another family in a nearby banana plantation. The RPF soldiers were surprised to find them and questioned her group. As Sylvia explained,

They asked those who remained, "Since we found this person killed near your home, who killed them? Where were you when they were killing them?" So they started gathering information about how these people were killed and who killed them and why. ${ }^{20}$

Sylvia's claims of ignorance prompted more questions. "What was your involvement? What did you do during this time? What were you doing? Because 
you never fled - you were in your house. And you don't know who killed this person? And you didn't flee?'” The RPF did not believe her when she claimed she had been at home and unaware of any killings. " "This person was killed next to your house and you are saying you didn't see the person who was killed?" Still, apart from their questions, the RPF left Sylvia alone. She was not arrested or held on suspicion of genocide crimes. Only much later was Sylvia sentenced by the Gacaca courts to 12 years for her participation in a killing mob. ${ }^{21}$

This obfuscating gendered lens that initially overlooked or ignored women perpetrators is not unusual to Rwanda. Human rights researcher Chiseche Salome Mibenge recently criticized the Truth and Reconciliation Commission in Sierra Leone's final report for perpetuating an "essentializing image of Sierra Leonean women and girls as perpetual victims not only of war but also of patriarchy in peacetime." ${ }^{22}$ In a study that included 39 women from Angola, Burundi, the Democratic Republic of Congo, Liberia, Rwanda, Sierra Leone, Somalia, Somaliland, South Africa, Sudan, Uganda, and Zimbabwe, gender and conflict scholar Dyan Mazurana found that, despite evidence of women's participation in conflict, women were often excluded from post-conflict initiatives intended to prevent further violence. "The majority of women and girls associated with armed opposition groups in Africa did not participate in official DDR [disarmament, demobilization, and reintegration] programs. The first primary reason is they are blocked by narrow definitions of 'combatant'. ${ }^{\prime 23}$ Another study by Mazurana and her colleague Susan McKay found that girl soldiers in Uganda, Sierra Leone, and Mozambique were overlooked by international and national nongovernmental organizations because, until very recently, girls had not been recognized as participants in fighting forces and subject to similar psycho-social trauma as boy soldiers. ${ }^{24}$ Elided as combatants or participants in genocide, women were excluded from post-conflict processes, including DDR, justice, and truth initiatives. ${ }^{25}$ In Rwanda, a similar oversight born of gendered stereotypes meant the majority of women perpetrators went unacknowledged and returned to their daily lives as though they had done nothing.

As early as 1995, researchers worried about future instability as a result of the gendered omission. The non-profit organization African Rights warned,

The national and international failure to address women's involvement in the genocide and murder of Hutu political opponents reinforces the impunity that is enjoyed by genocidal criminals. Many of these women are living in comfortable exile in Zaire, Kenya and Europe.... Thousands more are living in Rwanda, confident that their crimes will never be revealed. ${ }^{26}$

It took over a decade, but ultimately the repercussions of this gender-based impunity-by-attrition culture were recognized as subversive in Rwanda. As a result, the Gacaca courts were established to try men and women alike and bring justice to and further rehabilitate the post-genocide society.

In some cases, the women accused by Gacaca were caught unaware. Julie lived a full life up to and following the genocide. She was initially ignored by 
the authorities in her area, despite her husband's incarceration soon after the killing ended. Accused of participating in the genocide, he spent 12 years in prison while Julie remained at home with their children, raising them on her own and supporting the family through farming. She described relations in her area as friendly. "We do not have any grudge with each other, we are very ok." When Gacaca was established, court officials reached out to community members for personal accounts. "I was sitting at home when they came and brought a letter, calling people to come and give their testimonies of what they saw."27

Julie described an exchange with a neighboring woman who attended her church and who invited Julie to her home in order to request her testimony. While Julie was reticent to disclose the details of the conversation, she acknowledged that the woman pleaded with her to go to the Gacaca courts and beg for forgiveness. Julie was adamant that she had done nothing that required an apology. Still, eventually she was brought before Gacaca. In 2007, shortly after her husband's return from prison, she was found complicit in the murder of several Tutsi children and of espousing extremist rhetoric. She described the accusations against her as sudden and unexpected. "I really don't know where all these accusations came from.... We shared beer and stuff and afterwards when we came back, that's when these other [accusations] came out." ${ }^{\prime 28}$ In her mind, the relative "normality" that followed the genocide and reigned in her region for nearly a decade meant that her crimes had been forgotten, overlooked, and remained unknown. To be accused and convicted took her by surprise.

Although just one Tutsi woman remained in her immediate area, Gloria was quick to describe the post-genocide environment in her area as fraught with insecurity. "They used to come and attack people at night, but I didn't know where they were coming from." While it became clear that Gloria was referring to violence perpetrated by Tutsis, she avoided using the ethnic distinction and instead focused on the identity of the victims. "They would kill Hutus at night and we didn't know where they were coming from." Still, apart from the insecurity, she described a post-genocide life that revolved around her two adopted children and her husband. When the Gacaca courts were established, she testified against her in-laws, describing how they had banded together and murdered her husband's aunt by marriage because she was a Tutsi. Her in-laws in turn implicated Gloria, claiming she had not only witnessed the killing (which Gloria had admitted - "I went there because I had heard what was going on and I decided to go there and see"29) but had participated as well. Gloria's husband was devastated and could not believe it. "When they were taking me in the car in Gisenyi, he wept because he never believed that I could be along with the people who did this. ${ }^{30}$ He died shortly thereafter of unknown causes, convinced of his wife's innocence. Gloria is currently serving her sentence at a TIG camp.

The Gacaca courts closed in 2012 and the final report declared its work complete. Not everyone agrees. Asked in 2014 whether he believed the work of Gacaca was indeed finished, Denis Bikesha, former Director of Training, Mobilization \& Sensitization for Gacaca, asserted, "No, it's not really finished." While 
he was quick to acknowledge the accomplishments of the Gacaca courts, Bikesha also noted that some people hesitated to come forward to give their testimony, opting instead to wait to see how the process turned out before deciding to participate. Sometimes they waited too long. Then too, a number of high-level perpetrators remain abroad and have not faced justice. Without their full testimony, it is difficult to ascertain the actions of the planners of the genocide. And lastly, he cited genocide survivors who still do not know the whereabouts of their loved ones. "There are those who are telling us that the dead bodies of their family members have not been identified, have not been buried with dignity. So that shows that there is some truth that's being hidden somewhere." ${ }^{1}$

\section{Rescuer recognition}

Were women rescuers recognized and acknowledged by the local population, country, and broader international community? Until recently, women rescuers largely went unnoticed on the national and international levels, although their activities were often known to the community immediately following the genocide. Marginalization of rescuers remains a challenge for Rwanda and includes men and women alike. Some searches have been undertaken, including one conducted by IBUKA, an umbrella organization that supports survivors throughout Rwanda. IBUKA borrowed from standards established by Israel's Yad Vashem to identify: the "Righteous" and interpreted as: "a non-Jew who risked his/her life, freedom and security to rescue one or several Jews threatened by death or deportation to a death camp, without requesting any financial or other compensation." ${ }^{32}$ In Rwanda, this translated as a non-Tutsi who risked his/her life, freedom, and security to rescue one or several Tutsis threatened by death without requesting financial or other compensation. The pilot study covered just 14 percent of the sectors before funding ran out. ${ }^{33}$

Other organizations have sought to acknowledge rescuers in Rwanda. Examples include Learning From History, an organization that selected 15 rescuers from the IBUKA list to receive gifts; the Kigali Genocide Memorial's collection and publication of women-rescuer testimonies in its Genocide Archive of Rwanda; and a U.S. Department of State event held to mark the sixtieth anniversary of the United Nations' Refugee Convention. But these piecemeal initiatives have not brought significant gains. Once again, we find seemingly dichotomous priorities: the need to bring suspected perpetrators to trial became the primary focus of national and international efforts to develop a full rendering of the events that took place during the genocide. But what of the stories of rescue? They also constitute an important component of this history. And within these stories of agency and action, what of the women who rescued?

Response to rescue is shaped by ethnicity. Tutsis typically react to stories of rescue and rescuers with enthusiasm and warmth. Every so often, someone will learn of Rosanne's acts of rescue. She notes that Tutsis are more likely to approach her and express gratitude, saying “ 'Ohhhh, we got to know about you, what you did, thank you so much, that was so good." " ${ }^{34}$ Allison observed that, 
there was a lot of respect for me, especially from many people who survived. They kept on really telling others how heroic I am, standing and taking care of a kid I didn't know where it was coming from and taking care of her as my own child. ${ }^{35}$

Among Hutu neighbors, particularly those complicit in the perpetration of the genocide, the reaction is cold or hostile. In many instances, women rescuers continue to hide their acts of heroism for fear of retribution or, at the very least, alienation from Hutu neighbors. This has had lasting effects. These women experience a version of feminist sociologist Cynthia Cockburn's "continuum of violence," evident in disruption to their everyday life, displacement, continued insecurity, and silences buried. ${ }^{36}$ This has hindered further attempts to highlight acts of rescue in Rwanda.

Some women were unable to hide their rescue activities. Joan's neighbors were aware of her actions as soon as the RPF soldiers arrived in her area. "When the Inkotanyi came, they all took us to this camp in Byumba, Rutare. All of us, even those we had rescued, everyone. After that, they shifted us to another place in Byumba." ${ }^{37}$ As a result of being moved along with the Tutsis she had harbored to a protected internally displaced persons camp under RPF guard, the local community surmised that Joan and her husband had rescued. When they returned home, Joan saw the community's reaction. "We found out that our homes had been looted. They had destroyed, demolished everything, everything. ... And everything that was inside was taken." 38

The culprits were her neighbors. Because Joan and her husband had dared to rescue, "They took us as the same as the Tutsis. They said we are traitors." When the Gacaca courts began hearing cases in her area, Joan's neighbors unsuccessfully accused her husband of assisting the Interahamwe. Many of them were jailed and some were forced to pay for the damage done to her home. Twenty years later, Joan does not feel an immediate sense of threat but she is aware of her neighbors' underlying hostility.

My neighbors? It's just the normal routine. Although you really see there is something - they can't express it.... Of course outside, they don't show it. But because you don't see someone's heart, you can just feel it. But because they can't do anything, it's always like a camouflage, covered on the face, outside, people don't see. You just pretend the relationship is good but deep inside, you don't know what they think. ${ }^{39}$

While Joan was able to find a way to cope with her neighbors and develop a "normal routine," Ruth lives in a state of constant fear and insecurity because of her rescue activities. She insisted on giving her testimony but the act of retelling her experiences during the genocide was traumatizing. Her neighbors were well aware of her actions during the genocide and reported her to the Interahamwe and FAR on numerous occasions. These days, Ruth can barely speak to them. "They are always cursing. How would you feel secure when you are in a 
community that is always cursing you but because the government is watching so, that's why I'm still there?"40

Like Ruth, Martha feared reprisals from her neighbors if they learned what she did during the genocide. As a result, she had never publicly shared her testimony.

I always kept quiet. I didn't want to be in the spotlight because I was scared they would kill me. Because they used to throw insults to me where I used to stay, "When are you going to go and give birth to Tutsi babies;" "You go and the Inkotanyi will make you rich;" "You are nothing;" all sorts of things. ${ }^{41}$

In the midst of the genocide, her husband disappeared and his body was never discovered. From comments and taunts by her neighbors, Martha suspects that he was a victim of murder. Still, she remained with the six Tutsis she was hiding. When the RPF arrived in her area, she brought the Tutsis out, shocking some neighbors and confirming the suspicions of others. She then traveled with them to an internally displaced persons camp that was guarded by the RPF. Several months later, when she returned home with her four children, her neighbors attacked her as punishment for her acts of rescue, with her own godson beating her about the head.

So then they came and attacked me because they were saying, "Oh you are the person who hid the Tutsis." So they beat me seriously on my head. Actually, I still have [problems from the beatings] - it took me two months to recover. I found they had taken everything in the house, everything. So I spent three months, three months recovering from all these wounds, and I started my life over from scratch. ${ }^{42}$

One of her assailants was jailed, the other went free. The ongoing taunts of her neighbors served as a daily reminder that Martha was not safe. She moved with her children to another hill, lost faith in the Catholic Church, became a Jehovah's Witness, and kept her acts of rescue a secret, refusing to give her testimony to the government or various non-governmental agencies. "They always told me to come and give my testimony, but I always stayed away because I didn't want to be attacked again, I was like, 'I don't want to die the second time.' ",43

\section{Intersection of sex and security}

Women rescuers faced significant problems in post-genocide Rwanda, sometimes as a result of their bravery or eventual recognition, but also due to their sex. ${ }^{44}$ Women rescuers who lived alone were more likely to report feeling unsafe. Some openly discussed this intersection of sex and security, assessing their security according to the absence or presence of a man in the home.

Martha attributed her vulnerability to her status as a widow, with no man in her home to protect her. As she put it, "I was tried so much when especially my 
husband died.... And after that, that's why they came after me ... all my friends became my enemies.... I'm always scared now."45 This association between security and the presence or absence of a man in the household was a recurrent theme. Some expressed relief that they were not alone. Denise readily discussed the hostility of her neighbors and the importance of her husband's presence.

There are those who are not happy with what I did and those are the ones who used to actually mobilize the militias to come to my house. Even up to now, for a person who could mobilize or alarm or alert the militias to come in your home and kill the people you are hiding, even up to now there are those who are still not happy with what I did.

Still, she confided that, "Right now I feel safe and most especially because my husband came back and he was with me and I felt more safe. But if I was still alone, I don't think I would be safe here." 46

Others rejected this association and insisted that they were secure despite being the head of the household. Nicole, rescuer of a young boy, feels perfectly safe in her community, exclaiming, "I don't have any problems. I have full security - I'm safe. I have enough security here.” Her neighbors did not react negatively when the father of the child came forward and recognized her publicly for her act of rescue. Instead, "the community was very happy after hearing this deed that I did. Even those who didn't know [before the genocide ended], you could see that they were really happy. ${ }^{~} 47$ She and her three children openly discuss their experiences during the genocide and their family's role in saving a life. One possible reason for her confident assertions may be found in the fate of the perpetrators in her community: "those who participated, most of them are not around. They don't live here." ${ }^{48}$ Allison concurred with Nicole. Though she was the only woman in her area to rescue, she also does not feel tensions with her neighbors; on the contrary, "They're like 'Oh that woman is a real hero." ",49 Still, Josephine was the only interviewed woman rescuer who explicitly asked that her real name be used "so that people learn from it."

When asked if she felt comfortable and safe in her community, it didn't occur to Janet to discuss her personal well-being. She interpreted her sense of security in terms of her maternity, emphasizing the safety of the children she first rescued and later adopted.

I feel safe where I am because two of the kids have already gotten married. Now they have their own homes with the exception of the young one who is at school most of the time and also has an elder brother where she usually goes and then comes home and then goes back to school so I feel safe. I don't think I have any security problems. ${ }^{51}$

It is possible that Janet did not discuss personal insecurity as a result of her rescue because of her socioeconomic status. As an educated teacher in a position of prominence with a non-agrarian source of income, she may have been 
insulated from the insecurities and hostilities experienced by women who farmed for a living and relied upon their rural communities for their survival. ${ }^{52}$

Women who share the dual identity of rescuer and survivor face compounded risks. Margaret returned home after the genocide only to find her dwelling demolished and many of the perpetrators free. Although her house was later rebuilt and her daughter provided with a scholarship to study, Margaret continues to struggle with the frequent reminders of her loss. "There are some men that I know really participated but are still out there free. They haven't faced justice." 53 The one woman perpetrator she recognized from her experiences at Murambi passed away of natural causes before charges were brought. And "most the people that I see are men who participated and who are still out here." $" 54$ These regular reminders often traumatize her and prompt feelings of insecurity and isolation. With her daughter away at school, Margaret spends most of her time alone.

Some Tutsi survivors benefit from housing initiatives that provide security in numbers. One rescuer and survivor, Beth, explained the reason for her sense of security. "I don't have any problems because they [the government] built for us houses, a village for all survivors and I don't have any problem with my neighbors." ${ }^{55}$ Beth lives in a rural community built specifically for genocide survivors. As she does not regularly interact with people from outside her village, she feels safe. ${ }^{56}$ Still, she struggles with her trauma.

We stay together nicely except the only problem that I have is my sickness. This headache, it comes and sometimes I fall in a coma and I might spend like three months in a hospital and they have to take me to Kigali for treatment. ${ }^{57}$

Other women tend not to care about the opinions of their neighbors. As Rosanne asserted, 'I'm the way I am with everyone. I'm so - depends on what you think about me, I don't care. But I try to do my best to stay in peace with everyone.... I'm just the same with everyone." ${ }^{58}$ She holds a pragmatic view about her security and stability.

Bad people will always be there, you are not going to make everyone be on the same path with you. There will always be other bad people with bad intentions and mentality but to me, when I see how they are staying together, kids are going to school, you see the country is moving forward. ${ }^{59}$

Despite piecemeal efforts that have emerged to recognize and reward those who rescued during the genocide, the opportunity to celebrate and emulate women rescuers, models for society and the next generation of "upstanders," has thus far been largely overlooked. 


\section{Thanks}

IBUKA recently began to gift cows to rescuers of the genocide during the annual commemoration period. This expression of gratitude carries symbolic weight in the context of Rwanda's cattle culture and prior practices of cattle gifting. A pilot study report in 2010 noted that,

... each year, during the commemoration of genocide, IBUKA insists on showing a gesture of gratitude, however small, to the Righteous who rescued genocide survivors. So far, twenty-eight (28) persons have been so far honoured within this framework. The real goal of this ceremony is to promote acknowledgement of these courageous men and women on national as well as international level [sic]. The cow donation so far reserved to them may seem insignificant comparatively to their action and the risks they were exposed to, especially to a foreign observer. In reality, there is no price for their altruistic action. But in our tradition and culture, this donation represents the highest symbol for the esteem they enjoy. ${ }^{60}$

Three women, Wendy, Josephine, and Janet, were recipients of this initiative and were proud of the gift and recognition they received. ${ }^{61}$ But the practice also had an unintended consequence: it led to a rise in rescuer imposters who misrepresented themselves to obtain gifts from the state and non-profit organizations. This denigrated the process and those rescuers who deserved recognition. Then too, envy and jealousy accompanied those few women rescuers who have been recipients of this national initiative. Thus, local-level expressions of gratitude loom large.

Despite Amanda's poverty, when asked if Elana should be recognized for rescuing her and her children, she exclaimed, "What can I say to that question? It's obvious - I even, I wish I could have a cow to give her, really, as a gift of appreciating the act that she did." ${ }^{\prime 62}$ Elana has never been recognized by the local officials in her area. And despite the enormous respect and affection Allison receives from her neighbors in response to her rescue efforts, she has never been recognized.

The community where I stay - no one did anything like that. There is no one who rescued, no one rescued anyone in the area where I stay. And all of them know and up to now they love me because of what I did. But surprisingly there is no recognition of what I did, because I know some other rescuers were given cows or something and some other people came and asked me, "Why weren't you recognized and given something, a present, or a gift?" ... Maybe the local leaders should do something about it. But because they don't put anything for recognition, that's maybe why they don't given it priority and you are kind of, more like forgotten. ${ }^{63}$

Rosanne brushed aside the question of gratitude. For her, it did not matter. 
I must say that first of all, whatever I did, it wasn't based on being thanked or something. It was the right thing to do. I don't think anyone - whoever did it - did it to be thanked. It was the right thing to do and even at some point, I would find myself having done whatever I had to do. ${ }^{64}$

When asked if she was recognized for her acts of rescue, Joan began to laugh and exclaimed, "Not even a matchbox!" 65

But the perception among many, particularly in the western region of Rwanda where IBUKA conducted research on rescuers and gave gifts during commemoration events, was that rescuers were rich thanks to government and survivor largesse. For some, this exacerbated existing tensions. Ruth asked that we meet at a municipal office in the center of town, far from her home. She lamented,

I can't ask anybody even for salt because every time they see a visitor coming in my house, they think they have brought me money and they start talking, "Oh, they say that she saved people and they've come to give her money and make her rich," and stuff like that. ${ }^{66}$

Ruth's community already resented her for her acts of rescue. Now they felt justified in shunning her, thanks to these myths of wealth gained through rescue.

Many women rescuers remain impoverished as a result of their acts of rescue. As we have seen, Allison refused to give up the young girl she was hiding and resorted to bribery multiple times in order to save the young girl's life. "I would sometimes give him money or sometimes I would give him maybe a goat or anything that I had so that he would go." ${ }^{67}$ Eventually, Allison ran out of money and ran out of livestock and she resorted to lying to the Interahamwe, claiming that the girl was no longer in her home. Twenty years later, she continued to suffer from persistent poverty, unable to recuperate or make up for the lost wealth. For women like Allison, or Denise, who never made back the 20,000 RwF she paid to two Interahamwe in exchange for her life and the lives of her two charges, the economic consequences of rescue were devastating. Instead of receiving thanks, they and others live in indigent circumstances.

\section{Repercussions: perpetrators}

Reflecting on her experiences, Clémentine observed that,

the wives of the killers never talk about the genocide. They never mention this word among themselves. It no more exists than the repentance that goes with it.... They pray, they sing, they deny, and not only because they are afraid. They feel more furious than guilty. ${ }^{68}$

This fury harkens back to periods of Tutsi-rule in Rwanda and stems from instances of hardship and suffering following the genocide. Rather than 
acknowledging the complicity of the perpetrators, these women blame the victim groups and the RPF-controlled government.

What happens when a perpetrator population remains unacknowledged or is not subject to justice, rehabilitation, re-education, and reintegration into the civilian population? Rwanda is by-and-large stable with a strong and ever-present security apparatus. Kigali is a bustling and fast-developing city filled with people espousing their views on social media and enjoying fine dining and a lively night-life. Every so often, the fragility of this scene is briefly exposed. One morning in 2014, a rumor swept the country that President Paul Kagame was dead. It was just a rumor, the result of a paranoia that occasionally grips the country. But it sparked a range of responses. In Goma, a DRC city along Rwanda's northwestern border, celebrations broke out. People danced in the streets, reportedly carrying a coffin overhead. Hysteria and panic prevailed in parts of Rwanda, mostly rural. Some Rwandans even fled to the border. Clearly the security and stability that appeared to prevail, especially in the capital city of Kigali, was more tenuous than it seemed.

Women stand on the fault lines of the fragile stability that currently exists in Rwanda, and women perpetrators may have a destabilizing role, especially if they continue to deny their participation in the genocide and lay blame on a faulty judicial system. Traditionally responsible for raising the family, maintaining the home, and educating their children, Rwandan women are well positioned to transmit their ideologies. Odeth Kantengwa stressed the importance of parents. "This genocidal ideology was taught right from the family ... it was their [the children's] parents that had to narrate whatever happened, or whatever ideology they had, and this was transmitted from the parents to the children." ${ }^{69}$ If a mother denies the genocide, continues to perpetuate the ethnic divisions and hatred that preceded the genocide, or experiences bitterness for what she lost when she fled to Congo or was incarcerated, or her position in society was compromised, there is little doubt that she will influence her children. As Nederveen Pieterse has explained,

Prejudices are often said to be emotionally based, and therefore education and information are credited with having relatively little impact. Early socialization is usually regarded as particularly influential in the formation of a child's attitudes. Thus what happens in the nursery has a double importance: because it takes place in the emotional sphere and because early socialization carries so much weight, events there are both trivial and crucial. ${ }^{70}$

Many women perpetrators insisted that upon their release they would do the opposite: they would return home and teach their children coexistence and harmony. Asked what she would tell her children about the genocide, Cassie paused before responding.

I would tell them the reason I was away. I would tell them why I was jailed but also emphasize on them not listening to anything to do with the genocide 
and if anybody, anybody talked to them about doing anything like it to run away from that person, very far away if they can. And also, I will try to mend the relationship with my neighbors and whatever happened, ask for forgiveness, visit each other, share godparents with their children, and also intermarry and build the new Rwanda completely. Start all over.... And stay together. That is my target - this is what I want to do after TIG. ${ }^{71}$

This peaceful coexistence Cassie envisioned for her children stands in stark contrast to the divisionism and violence that had defined her life.

It is possible that women perpetrators are traumatized by their experiences during the genocide and require additional rehabilitation and treatment. During the twentieth commemoration of the genocide in 2014, Mukesh Kapila made a powerful point when he suggested that perpetrators of the genocide were traumatized by the genocide and their guilt. Their collective response was to deny the crime and their individual role in its perpetration. Perhaps women who lie about their crimes believe their version of the event and no longer remember their participation. What are the implications for unity and reconciliation when a group willfully, or as a result of trauma, experiences collective amnesia? And if women perpetrators deny the crimes of genocide and respond with anger rather than guilt or repentance, youth may be indoctrinated. It is in this domestic space that either a new generation of extremists, denialists, and angry youth, or, alternatively, a new generation of upstanders, forms.

\section{Repercussions: rescuers}

Women rescuers' anonymity may shield them from further insecurity but this silence shapes the national discourse which, in turn, prolongs and preserves the silence. ${ }^{72}$ Although these women require protection due to their vulnerability, their stories are essential to the genocide narrative for several important reasons. First, documenting rescue by women may counter the culture of silence and fear that currently accompanies most women rescuers. Making their stories mainstream, accepted, and cause for celebration would shift the paradigm of rescuers and make it socially unacceptable to target them for discrimination or violence.

Then too, their experiences enrich the narrative of the genocide in Rwanda that is still being developed. This is an untold chapter of great importance to policy makers and the Rwandan people, and would add to the historical record as well as the nation's efforts to rebuild. Elucidating the complicated story of women rescuers during the genocide in Rwanda also assists efforts to document, learn from, and prevent mass violence. Additionally, identifying rescuers who could then serve as peace brokers may benefit Rwanda's efforts to unify the country. Naphtal Ahishakiye, executive secretary of IBUKA, highlighted the role of rescuers as a potential bridge between survivors and perpetrators living in communities where rescuers are known and celebrated. He contended that rescuers are also more likely to be trusted by the survivor community as a result of 
their heroism and also by the perpetrators because of their shared ethnic background..$^{73}$ As a result, they may play a role in facilitating reconciliation.

Psychologist Ervin Staub has noted that there are widespread benefits to the act of rescue. Rescue motivates self-help, empowers both the rescuer and others, inspires others, creates a more caring society, and can lead to a form of altruism born of suffering. Those who have been helped or have helped themselves are more liable to help others. ${ }^{74}$ These stories thus serve future generations.

Investigation and recognition of women rescuers provide an opportunity to celebrate and emulate the women who rejected the culture of genocide and took a stand against the murderers. Embodiments of the U.S. Ambassador to the United Nations Samantha Power's concept of "upstanders," women rescuers can serve as role models for the next generation of youth in Rwanda. Rwanda's prisons and TIG work camps are filled with genocide perpetrators who serve as cautionary tales for the youth: women rescuers provide that generation with positive examples of who they could become.

\section{Transitioning gender norms?}

While Rwanda's effort to institute a policy of gender balance has produced impressive results, the government still has a way to go to ensure real, meaningful, and widespread gender equality. A continued rural-urban divide extends into culturally dictated codes of conduct for men and women. In the city centers, women participate actively in meetings, take lead roles in the household, make financial decisions, indeed, even wear pants. All of these are less common in the rural regions, where women typically dress in skirts, speak quietly into their hands, or, in many instances, allow the men to speak on their behalf, and frequently defer to the men in their households to make decisions. These disparities speak to a widening divide between Rwanda's urban centers and its rural regions and to the very different spaces available to women in the respective political and public spheres.

The capital, Kigali, struggles with gender equality, too. Advertising in Rwanda has become incredibly savvy, with flashy headlines, catchy tunes, and clever messages. One particular billboard, seen in a host of locations, advertised a local beer, "Turbo." The ad showcased a handful of half-dressed muscular men dressed for construction work. The logo nzoga y'abagabo, or "beer for" or "of men," blazed proudly. Women have made many advances in Rwanda but still, the culture is rife with norms about masculinity, "manly" occupations, and their accompanying beverages. It is in this space that women are obscured and their anonymity perpetuated by gendered norms about women.

Gender norms and stereotypes continue to adapt with the times. Radio shows remain popular in Rwanda, reaching rural and urban audiences simultaneously. An English-language shock-jock radio show on one of Rwanda's popular radio stations intended for a more international and (often) educated and informed multi-lingual audience, articulated deeply embedded patriarchal values. One morning, the first segment focused on how a woman should treat her husband. 
The male host was very direct in his recommendations: women should take care of their husbands the same way their mother would but, in the bedroom, "they must be a slut." The next segment focused on pregnancy and abortion, a relatively new issue for public debate in post-genocide Rwanda. Another man took charge of the conversation and placed responsibility for birth control solely on women and refused to discuss any male responsibility for contraceptives. When his female co-host tried to raise this point and address the shared responsibility of men and women in the prevention of unwanted pregnancy, he accused her of getting an abortion and being a sullied woman.

This issue can be found in academia as well. During a discussion of women's rights, scholar Ezechial Sentama lamented,

We're teaching the men to give rights to women instead of teaching men to give love to their women.... Because if we have love, I make sure you have all the rights you could afford. I will give you the rights. ${ }^{75}$

This statement is predicated on the belief that the rights of a woman - her human rights, her universal rights - are in the possession of men and that they are his to give to her. It was not an anomalous sentiment; similar beliefs and norms can be found in modern Rwandan culture, music, and practices. His argument hints at a continuum of patriarchy within Rwandan society that has yet to be fully unearthed and addressed.

While there has been considerable progress in Rwanda, there is more to be done to ensure that gender mainstreaming and gender equality are both priorities and indicators of post-conflict reconstruction and rehabilitation. Rwanda has taken measures to guarantee that women and girls play a meaningful role in the development of the country, reserving a space in which women operate in the political and public spheres. The government has enacted laws that correct preconflict gender-based marginalization or discrimination. Yet, although women have been empowered in the public and political spheres, in their private, domestic sphere they remain constrained by deeply engrained prescribed and proscribed gender roles that have yet to be uprooted. The ten-year lapse in judicial processes for perpetrator women and continued marginalization of women rescuers serves as both a cause and a symptom of the work that remains to be done. It is in this continuously evolving space that the role of women rescuers and perpetrators has the potential to have a significant impact.

\section{Notes}

1 Laura Sjoberg and Carol Gentry, Mothers, Monsters, Whores: Women's Violence in Global Politics (London: Zed Books, 2007): 172.

2 Between Munyenyezi's trials, the same team of prosecutors tried Kantengwa, who was convicted of immigration fraud. She had received refugee status in 2004 despite her documented political affiliation with the MRNDD government and had lived a free life in Massachusetts before the court's verdict.

3 United States v. Beatrice Munyenyezi, 13 F. 1950 (1st Cir. 2015). 
4 Kelly D. Askin, “The Quest for Post-Conflict Gender Justice," Columbia Journal of Transitional Law 41, (2002-3): 513.

5 Similar to women rescuers in Rwanda, Holocaust rescuers studied by psychologists Pearl and Samuel Oliner rarely sought acknowledgement for myriad reasons. See Samuel P. Oliner and Pearl M. Oliner, The Altruistic Personality: Rescuers of Jews in Nazi Europe (New York: The Free Press, 1988).

6 United States Institute for Peace, "Rwanda: Accountability for War Crimes and Genocide - Special Report" (January 1995): 5.

7 Interview Aloisea Inyumba, interview by Sara E. Brown, Kigali, Rwanda, 7 June 2011.

8 Ibid.

9 Ibid.

10 For more on the role of the state in addressing gender equality, see: Valerie M. Hudson, Bonnie Ballif-Spanvil, Mary Caprioli, and Chad F. Emmett, Sex and World Peace (New York: Columbia University Press, 2012).

11 Stanley Cohen, States of Denial: Knowing About Atrocities and Suffering (Cambridge: Polity Press, 2001): 138.

12 USAID, "Rebuilding Postwar Rwanda: The Role of the International Community," Evaluation Special Study Report no. 76 (July 1996): vi. (A variation of this quote is cited on page 12 of the Joint Evaluation of Emergency Assistance for Rwanda report titled "Rebuilding Postwar Rwanda.")

13 The challenges facing post-conflict reconstruction and rehabilitation are not limited to Rwanda. See, inter alia: Sultan Barakat, "Setting the Scene for Afghanistan's Reconstruction: The Challenge and Critical Dilemmas," Third World Quarterly 23, no. 5 (October 2002): 801-16; Derek Chollet and James M. Goldgeier, "The Faulty Premises of the Next Marshall Plan," The Washington Quarterly 29, no. 1 (Winter 2005-06): 7-19; Paul Collier and Anke Hoeffler, "Aid, Policy and Growth in PostConflict Societies," European Economic Review 48, no. 5 (October 2004): 1125-45; Sara Gibbs, "Post-War Social Reconstruction in Mozambique: Re-Framing Children's Experience of Trauma and Healing," Disasters 18, no. 3 (2007): 268-76; John J. Hamre and Gordon R. Sullivan, "Towards Postconflict Reconstruction," The Washington Quarterly 25, no. 4 (Autumn 2002): 85-96; and James Rae, "War Crimes Accountability: Justice and Reconciliation in Cambodia and East Timor?" Global Change Peace \& Security 15, no. 3 (June 2003): 157-78.

14 USAID: viii.

15 Ibid.

16 Both deemed necessary components of what sociologist Erving Goffman identifies as the "personal front." For more, see: Erving Goffman, The Presentation of Self in Everyday Life (New York: Anchor Books, 1959).

17 Interview G 17 "Deena," interview by Sara E. Brown, Jali, Rwanda, 16 February 2014.

18 See Chapter 5, "Perpetrators."

19 Interview G 14 "Kathleen," Interview by Sara E. Brown, Ngororero, Rwanda, 21 February 2014.

20 Interview G 21 "Sylvia," interview by Sara E. Brown, Cyungo, Rwanda, 13 March 2014.

21 Ibid.

22 Chiseche Salome Mibenge, Sex and International Tribunals: The Erasure of Gender from the War Narrative (Philadelphia: University of Pennsylvania Press, 2013): 89.

23 Dyan Mazurana, "Women in Armed Opposition Groups in Africa and the Promotion of International Humanitarian Law and Human Rights and Human Rights," Program for the Study of International Organization(s) (2005): 5.

24 Dyan Mazurana and Susan McKay, "Where are the Girls? Girls in Fighting Forces in Northern Uganda, Sierra Leone, and Mozambique: Their Lives During and After War," Rights \& Democracy (2004). 
25 This gendered lens functions across time and geography. For example, during the Nazi era, women nurses at Obrawalde psychiatric hospital in Germany participated in the Nazi's T-4 euthanasia program, murdering 18,232 patients. It took 19 years to try the nurses and all 14 were acquitted and found to be agency-less orderlies following orders. See: Susan Benedict and Jane M. Georges, "Nurses in the Nazi 'Euthanasia' Program," Advances in Nursing Science 32, no. 1 (2009): 63-74.

26 African Rights, Rwanda: Not So Innocent - When Women Become Killers (London: African Rights, 1995): 4.

27 Interview G 24 "Julie," interview by Sara E. Brown, Rwamagana, Rwanda, 29 April 2014.

28 Ibid.

29 Interview G 15 "Gloria," interview by Sara E. Brown, Ngororero, Rwanda, 21 February 2014.

30 Ibid.

31 Interview Denis Bikesha, interview by Sara E. Brown, Kigali, Rwanda, 15 January 2015.

32 Jean-Marie Kayishema and François Masabo, "The Rwandan Righteous 'Indakemwa' Pilot Study," IBUKA (December 2010): 13.

33 Interview Naphtal Ahishakiye, interview by Sara E. Brown, Kigali, Rwanda, 14 January 2014.

34 Interview R 15 "Rosanne," interview by Sara E. Brown, Kanombe, Rwanda, 29 April 2014.

35 Interview R 4 "Allison," interview by Sara E. Brown, Butare, Rwanda, 20 February 2014.

36 Cynthia Cockburn, "The Continuum of Violence." In Sites of Violence, edited by Wenona Giles and Jennifer Hyndman (Los Angeles: University of California Press, 2004): 24-44.

37 Interview R 14 “Joan,” interview by Sara E. Brown, Gasabo, Rwanda, 24 April 2014.

38 Ibid.

39 Ibid.

40 Interview R 7 "Ruth,” interview by Sara E. Brown, Kibuye, Rwanda, 22 February 2014.

41 Interview R 12 "Martha," interview by Sara E. Brown, Gasabo, Rwanda, 24 April 2014.

42 Ibid.

43 Ibid.

44 Gender-based insecurity is common in post-conflict societies. See, for example, Tilman Brück and Marc Vothknecht, "Impact of Violent Conflicts on Women's Economic Opportunities." In Women and War: Power and Protection in the 21 st Century, edited by Kathleen Kuehnast, Chantal de Jonge Oudraat, and Helga Hernes (Washington, DC: United States Institute of Peace Press, 2011): 85-114; and the aforementioned book by J. Ann Tickner, Gendering World Politics (New York: Columbia University Press, 2001). Still, in Rwanda, women have organized with some success to counteract this insecurity. See Erin Baines, "Les Femmes aux Mille bras: Building Peace in Rwanda." In Gender, Conflict, and Peacekeeping, edited by Dyan Mazurana, Angela Raven-Roberts, and Jane Parpart (New York: Roman and Littlefield Publishers, Inc., 2005): 220-41; Sara E. Brown, "Reshaping Gender Norms in PostGenocide Rwanda," Genocide Studies International, 10, no. 2 (Fall 2016): 230-250 and Swanee Hunt, Rwandan Women Rising (Durham: Duke University Press, 2017).

45 Interview R 12 "Martha."

46 Interview R 9 "Denise," interview by Sara E. Brown, Rwamagana, Rwanda, 18 March 2014.

47 Interview R 11 "Nicole," interview by Sara E. Brown, Rwamagana, Rwanda, 18 March 2014. 
48 Ibid.

49 Interview R 4 "Allison."

50 Interview R 6 Josephine Dusabimana, interview by Sara E. Brown, Kibuye, Rwanda, 20 February 2014.

51 Interview R 5 "Janet," interview by Sara E. Brown, Butare, Rwanda, 20 February 2014.

52 See Chapter 7, "Sharing Salt," for more on the significance of sharing and interdependency in rural Rwanda.

53 Interview R1, S 1 "Margaret," interview by Sara E. Brown, Murambi, Rwanda, 28 June 2011.

54 Ibid.

55 Interview R 8, S 6 "Beth," interview by Sara E. Brown, Kibuye, Rwanda, 22 February 2014.

56 Beth's sense of security in her government-constructed village contrasts sharply with the conclusions drawn by Catharine Newbury. See her chapter, "High Modernism at the Ground Level: The Imidugudu Policy in Rwanda." In Remaking Rwanda: State Building and Human Rights after Mass Violence, edited by Scott Straus and Lars Waldorf (Madison: University of Wisconsin Press, 2011): 223-39.

57 Interview R 8, S 6 "Beth."

58 Interview R 15 "Rosanne."

59 Ibid.

60 Kayishema and Masabo, “The Rwandan Righteous": 12.

61 Josephine opted for a cash gift because she did not have the land necessary for animal husbandry.

62 Interview S 8 “Amanda," interview by Sara E. Brown, Rwamagana, Rwanda, 14 March 2014.

63 Interview R 4 "Allison."

64 Interview R 15 "Rosanne."

65 Interview R 14 "Joan."

66 Interview R 7 "Ruth."

67 Interview R 4 "Allison"; See Chapter 4, "Rescuers."

68 Jean Hatzfeld, Machete Season: The Killers in Rwanda Speak (New York: Farrar, Straus and Giroux, 2005): 233.

69 Interview Odeth Kantengwa, interview by Sara E. Brown, Kigali, Rwanda, 16 June 2011.

70 Jan Nederveen Pieterse, White on Black: Images of Africa and Blacks in Western Popular Culture (New Haven: Yale University Press, 1992): 166. There is a significant popular and scholarly literature on transgenerational taught hate. Nelson Mandela wrote in his memoir Long Walk to Freedom (New York: Little, Brown and Company, 1994) that, "No one is born hating another person because of the color of his skin, or his background. Or his religion. People must learn to hate ... for love comes more naturally to the human heart than its opposite." See examples: Mary Elizabeth Massy, Women in the Civil War (Lincoln: University of Nebraska Press, 1966) on hatred passed down from mother to child during the Civil War era in the United States; Kathleen M. Blee, Women of the Klan: Racism and Gender in the 1920s (Los Angeles: University of California Press, 2009) on the role of the mother in teaching race-based hatred; the already cited by Jan Nederveen Pieterse, White on Black on the influence of race-based stereotypes and imagery on generations; the aforementioned book by the Oliners, The Altruistic Personality on the impact of parental conditioning on future acts; and Ervin Staub, The Roots of Evil: The Origins of Genocide an Other Group Violence (New York: Oxford University Press, 2011).on the significance of learning by doing and the role of the parent.

71 Interview G 8 "Cassie," interview by Sara E. Brown, Ngoma, Rwanda, 14 February 2014. 
72 For more on the power of silences, see Cynthia Enloe, The Curious Feminist: Searching for Women in a New Age of Empire (Los Angeles: University of California Press, 2004), especially Part I.

73 Interview Naphtal Ahishakiye.

74 Ervin Staub's keynote address, "Picturing Moral Courage: Stories of Rescue Conference," Sarajevo, Bosnia-Herzegovina, 15 July 2011.

75 Interview Ezechial Sentama, interview by Sara E. Brown, Kigali, Rwanda, 25 June 2011.

\section{References}

African Rights. Rwanda: Not So Innocent - When Women Become Killers (London: African Rights, 1995).

Askin, Kelly D. "The Quest for Post-Conflict Gender Justice," Columbia Journal of Transitional Law 41 (2002-3): 509-21.

Cockburn, Cynthia. "The Continuum of Violence." In Sites of Violence, edited by Wenona Giles and Jennifer Hyndman, 24-44 (Los Angeles: University of California Press, 2004).

Cohen, Stanley. States of Denial: Knowing About Atrocities and Suffering (Cambridge: Polity Press, 2001).

Hatzfeld, Jean. Machete Season: The Killers in Rwanda Speak (New York: Farrar, Straus and Giroux, 2005).

Interview Aloisea Inyumba. Interview by Sara E. Brown. Kigali, Rwanda, 7 June 2011. Interview Denis Bikesha. Interview by Sara E. Brown. Kigali, Rwanda, 15 January 2015. Interview Ezechial Sentama. Interview by Sara E. Brown. Kigali, Rwanda, 25 June 2011. Interview G 8 "Cassie." Interview by Sara E. Brown. Ngoma, Rwanda, 14 February 2014.

Interview G 14 “Kathleen.” Interview by Sara E. Brown. Ngororero, Rwanda, 21 February 2014.

Interview G 15 “Gloria.” Interview by Sara E. Brown. Ngororero, Rwanda, 21 February 2014.

Interview G 17 “Deena.” Interview by Sara E. Brown. Jali, Rwanda, 16 February 2014.

Interview G 21 "Sylvia." Interview by Sara E. Brown. Cyungo, Rwanda, 13 March 2014.

Interview G 24 "Julie." Interview by Sara E. Brown. Rwamagana, Rwanda, 29 April 2014.

Interview Naphtal Ahishakiye. Interview by Sara E. Brown. Kigali, Rwanda, 14 January 2014.

Interview Odeth Kantengwa. Interview by Sara E. Brown. Kigali, Rwanda, 16 June 2011. Interview R1, S 1 "Margaret." Interview by Sara E. Brown. Murambi, Rwanda, 28 June 2011.

Interview R 4 “Allison.” Interview by Sara E. Brown. Butare, Rwanda, 20 February 2014.

Interview R 5 “Janet.” Interview by Sara E. Brown. Butare, Rwanda, 20 February 2014.

Interview R 6 Josephine Dusabimana. Interview by Sara E. Brown. Kibuye, Rwanda, 20 February 2014.

Interview R 7 “Ruth.” Interview by Sara E. Brown. Kibuye, Rwanda, 22 February 2014.

Interview R 8, S 6 "Beth.” Interview by Sara E. Brown. Kibuye, Rwanda, 22 February 2014.

Interview R 9 “Denise.” Interview by Sara E. Brown. Rwamagana, Rwanda, 18 March 2014. 


\section{Post-Genocide Trajectories}

Interview R 11 "Nicole." Interview by Sara E. Brown. Rwamagana, Rwanda, 18 March 2014.

Interview R 12 "Martha.” Interview by Sara E. Brown. Gasabo, Rwanda, 24 April 2014. Interview R 14 “Joan.” Interview by Sara E. Brown. Gasabo, Rwanda, 24 April 2014.

Interview R 15 "Rosanne.” Interview by Sara E. Brown. Kanombe, Rwanda, 29 April 2014.

Interview S 8 “Amanda." Interview by Sara E. Brown. Rwamagana, Rwanda, 14 March 2014.

Kayishema, Jean-Marie, and François Masabo. "The Rwandan Righteous 'Indakemwa' Pilot Study.” IBUKA (December 2010).

Mazurana, Dyan. "Women in Armed Opposition Groups in Africa and the Promotion of International Humanitarian Law and Human Rights and Human Rights." Program for the Study of International Organization(s) (2005).

Mazurana, Dyan, and Susan McKay. "Where are the Girls?: Girls in Fighting Forces in Northern Uganda, Sierra Leone and Mozambique: Their Lives During and After War." Rights \& Democracy (2004).

Mibenge, Chiseche Salome. Sex and International Tribunals: The Erasure of Gender from the War Narrative (Philadelphia: University of Pennsylvania Press, 2013).

Pieterse, Jan Nederveen. White on Black: Images of Africa and Blacks in Western Popular Culture (New Haven: Yale University Press, 1992).

Sjoberg, Laura, and Carol Gentry. Mothers, Monsters, Whores: Women's Violence in Global Politics (London: Zed Books, 2007).

Staub, Ervin. Keynote address. "Picturing Moral Courage: Stories of Rescue Conference,” Sarajevo, Bosnia-Herzegovina, 15 July 2011.

USAID. "Rebuilding Postwar Rwanda: The Role of the International Community." Evaluation Special Study Report no. 76 (July 1996).

United States v. Beatrice Munyenyezi, 13 F. 1950 (1st Cir. 2015).

United States Institute for Peace. "Rwanda: Accountability for War Crimes and Genocide - Special Report” (January 1995). 


\title{
7 Sharing Salt
}

\author{
"Umuntu asiga ikimwirukaho ntasiga ikimurimo." \\ A person can escape from something that is chasing after her/him, \\ but s/he cannot escape from what's inside of her/him.
}

(Rwandan proverb)

Women working in a line in the fields, hoes swinging in unison, preparing a field for cultivation, is a common sight in rural Rwanda. The women are not day laborers nor are they working collectively owned land. Most of the time, the land they till belongs to a single family and their labor is voluntary. Such community efforts prevail. When someone needs assistance, the community is expected to come together to help prepare land for cultivation, erect a home, assist in medical emergencies, and provide material support during hard times. The interconnectedness of communities, particularly in rural areas, is necessary to ensure survival during health crises, failed crops, droughts, and other hardships. Rural society is founded upon this interdependency and cooperation; to prosper as a community, the individuals that comprise the group must be protected.

Thus, community members share. From voluntary labor to basic food items and water, sharing is a cornerstone of the hillside patchwork of farming plots that comprise a community in rural Rwanda. Sharing in its myriad forms is also part of customary behavioral norms known as ikinyabupfura, an umbrella term for proper behavior. Without sharing practices, particularly in the rural regions, the social fabric that binds the community together begins to fray. Journalist Philip Gourevitch provides an anecdote that indicates the at once personal and communal nature of sharing. One night, stranded on the road to Kibuye, a lakeside town in western Rwanda, he heard the whooping cry of a woman followed by a cacophony of ululating responses. Later, a Rwandan explained to him that the woman cried out because she was being sexually assaulted and the responding cries were her neighbors.

He explained the whooping we'd heard was a conventional distress signal and that it carried an obligation. "You hear it, you do it, too. And you come running ... no choice. You must. If you ignored this crying, you would have 
questions to answer. This is how Rwandans live in the hills.... The people are living separately together so there is this responsibility."1

Sharing thus serves as an important indicator of post-genocide unity and reconciliation. Sharing, as demonstrated through customary behaviors and social practices, came up frequently in interviews, from the sharing of beer and salt to the sharing of supplies for a wedding. Many respondents measured their relationships by the degree of sharing - the more sharing, the stronger the relationship, the less sharing, the more tenuous. The pervasiveness of sharing, specifically necessary items such as water and salt, provides an indication, symbol, and cultural reference point of friendship, trust, reconciliation, and unity, and is of great significance in post-genocide Rwanda.

\section{Sharing pre-genocide}

According to Emmanuel Nshimyimana, former Gacaca and Kigali Genocide Memorial staff member, sharing was the basis of pre-genocide Rwandan culture. "In our society, the people, we are living together in villages, sharing the things. Sometimes in the areas where they don't have the cars, if they have the one who is sick, they can help each other to bring to hospitals and other things." 2 Nshimyimana stressed the inclusive nature of this ethos of sharing. He blamed the government for introducing hatred and suspicion into rural communities that, prior to the genocide, had shared everything regardless of ethnicity. In contrast to this narrative, Odeth Kantengwa noted that while sharing was and remains of great significance in Rwanda, it was not always uniform between ethnic groups. In some instances, preference was given to members of the same ethnic group at the expense of the other ethnicity, indicating rifts under the surface that were violently exposed during the genocide. ${ }^{3}$ In even greater contrast, scholar Phil Clark conducted over 200 interviews with Gacaca judges, genocide suspects, and survivors, and concluded that, "An overview of Rwandan history makes it difficult to accept that this allegedly lost sense of unity ever existed."4

Still, some women perpetrators referenced sharing as a sign of inter-ethnic cooperation and community health prior to the genocide. When asked what life was like before the genocide, Alexa asserted, "We were very peaceful, we were staying together, we shared everything." Cindy agreed, describing relations between Hutu and Tutsis in her area as strong and the community united. "We used to share everything, we used to stay together, drink together, share everything together." Deena had warm memories of inter-ethnic cooperation and affection prior to the onset of the genocide. "Since even before the genocide, we lived happily together. Kids were playing together, we would share everything. My kids would be going to their mothers...."7 Deena emphasized the attention and care children received from all of the community's mothers, irrespective of ethnicity. Laura specifically referenced the high prevalence of sharing among the Hutu and Tutsi members of her church congregation. "We used to pray together and be together and share everything." 9 
Like Emmanuel Nshimyimana, some women perpetrators blamed the government for inciting hatred and dividing previously united communities. Lynn spoke specifically about the detrimental effects of the MRNDD political meetings in her area on the pervasive culture of sharing culture in her community before the genocide. She recalled worrying at the time that, "they are trying to separate us yet we have been living together, sharing everything together, and their ideas during the meetings are totally destroying this community." ${ }^{10}$ Cindy agreed and asserted the genocide was, "something that was planned by the bad government," not by the local communities. These detailed descriptions of pregenocide unity and sharing contrast sharply with the events of April, June, and July 1994. While these women perpetrators readily described the pre-genocide period as one of peace and inter-ethnic cooperation, and the ethnic divisions as the work of bad governance, they and many others still forsook their Tutsi neighbors during the genocide.

The concurrence of several women rescuers with these depictions of life before the genocide bolsters the authenticity of women perpetrator accounts. Janet described in detail her affection for her Tutsi neighbors. "We used to share everything, they were godparents for my kids and I was a godparent for their kids." ${ }^{\prime 11}$ While it does not include the responsibilities and obligations common in western societies, the role of godparent in Rwanda is especially meaningful and indicates a close intimacy between families. Janet combined the intimacy of godparenting with that of sharing to illustrate how close she was with her neighbors.

When asked if tensions existed in her community before the genocide, Allison openly acknowledged that the Hutu and Tutsi communities were distinct and separate in her area. Still, she referenced sharing as an indicator of inter-ethnic harmony.

We were more like a separate community. They are on one hill and we were on another.... As much as we might have been staying more separately, we used to share most of the time. [We would] even go out and drink together, share. At gatherings, we would be together, we were staying together in harmony as much as the community was, you know, located in a more or less separate kind of way. But we shared everything together. ${ }^{12}$

For Allison, although the Tutsi and Hutu communities maintained a degree of ethnic-based separation, that they came together at social functions and shared demonstrated their peaceful coexistence.

Beth recognized persistent ethnic divisions in pre-genocide Rwanda, yet she described Hutu-Tutsi relations at that time in generally positive terms and the onset of the genocide as both sudden and unanticipated. "We used to stay together, share everything together, inter-marrying - you wouldn't see any problems." According to her, "The problem came afterwards."13 Beth was not aware of an escalation in ethnic divisionism or hateful rhetoric leading up the genocide. She was also not alone in expressing astonishment. One woman rescuer interviewed by the Kigali Genocide Memorial recalled her shock at the events of 
April 1994 because, "Before, people could not kill each other, people were sharing everything." 14 For her, the violence that erupted during the genocide came as a total surprise in part because of the high level of inter-ethnic sharing in her area; she was astounded when the genocide began.

Community stakeholders, perpetrators, and rescuers alike described a high frequency of sharing among Rwandans. While some alluded to pre-existing divisions or preferential treatment, references to sharing were recurrent and their illustrations diverse. Combined, they indicate a high prevalence of sharing prior to the genocide and its significance as the cornerstone of community strength and well-being.

\section{Sharing during genocide}

When the genocide began, the culture of sharing fractured, as did the traditional gendered role of women, rule of law, and state institutions. The social fabric that bound Rwanda together was rent apart, ikinyabupfura was blatantly ignored, and the traditions of sharing and cooperation - the foundation of Rwandan rural life and inter-connectedness - was upended. Key extremists, the government, and their media outlets manipulated the binding ties of community interconnectedness and shared responsibility to perpetuate and justify genocide as necessary for community survival and stability. Hutus turned on their Tutsi neighbors, murdering, raping, and stealing. Mass murder became a bonding rite for Hutus with the shared goal of Tutsi eradication.

The prevalence of theft during the genocide indicates the complete perversion of the previous norm of sharing. Analysis of a sample of Gacaca courts trials shows over 90 percent of trials convicting women were for Category 3 offenses (see Figures 7.1 and 7.2). ${ }^{15}$

These figures indicate the high incidence of theft among women perpetrators tried by the Gacaca courts. The prevalence of Category 3 crimes exists across

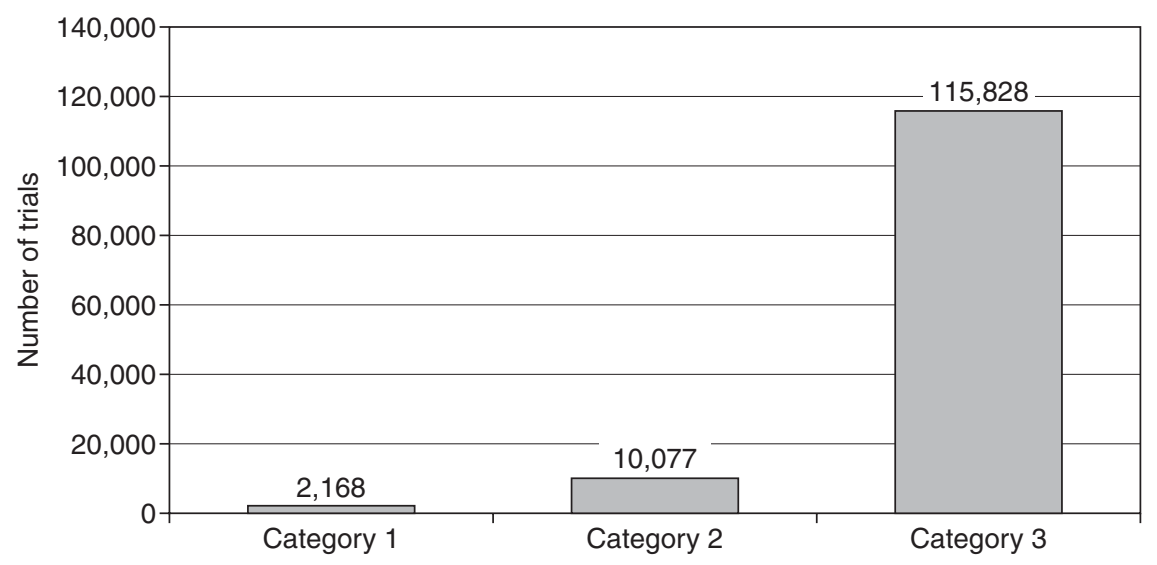

Figure 7.1 Women found guilty in Gacaca court trials. ${ }^{16}$ 


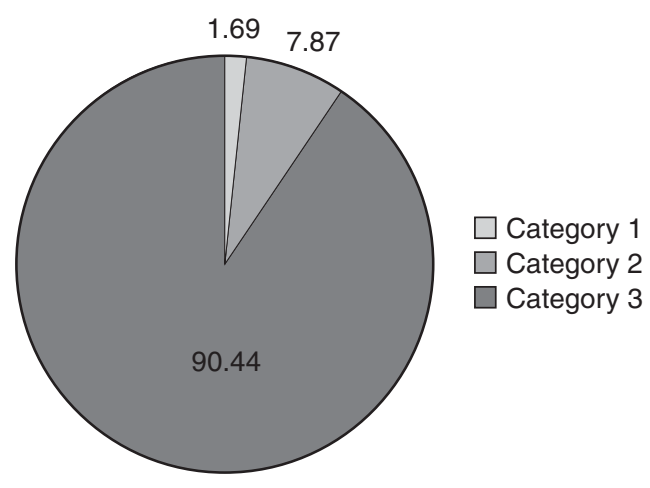

Figure 7.2 Percentage of Gacaca trials with a guilty verdict for women, by category of crime. ${ }^{17}$

sexes; a 2012 report found that of the 1,958,634 cases tried by Gacaca, 1,266,632 were Category 3 offenses. But the role of women in facilitating and perpetrating theft during the genocide speaks both to the breakdown of societal norms that dictated inter-personal relations and to a shift in the gender norms that dictated women's behavior.

Survivors of the genocide recalled the high incidence of theft and destruction perpetrated by men and women alike. One survivor, Gabriella, lost her entire family save for three people, and noted that the perpetrators not only murdered and raped, they also stole. "They destroyed all the houses and stole everything. They left nothing. They even cut down the banana trees. They left nothing.",18 Another survivor, Marjorie, also described both destruction and theft. When asked what was stolen, she replied, "Everything, all the contents of the house, they ate our cows." ${ }^{.19}$ Meredith recalled that before setting her home afire, Hutu community members looted it and took all of her belongings. ${ }^{20}$ And Jamie detailed the nefarious intentions of her neighbors.

There was even a neighbor with whom we had made an alliance by gifts of cows, but instead of saving us, they only waited for us to leave so they could pillage our goods, because everyone wanted to loot before the others did. These were people we considered friends, who maliciously plotted to take our belongings. They came and said, "Isn't it prudent for you to give me your goods so I can safeguard them and return them if you survive?" We had no response to this, knowing the whole time that our hour had come. ${ }^{21}$

A number of women perpetrators readily recounted instances of widespread theft during the genocide, though they were reticent to admit their role in perpetrating these acts. Kathleen explained the succession of crimes in chronological order. "They would kill them, afterwards they would take their things, they would loot, and then they would take their cows and everything. ${ }^{.22}$ Both Deena and Elaine 
recalled witnessing women robbing Tutsi gardens and stealing food, such as sweet potatoes. Some women perpetrators argued that their incarceration was a result of exposing theft perpetrated by their neighbors. Kristen claimed she was reported to Gacaca by one woman who sought revenge because Kristen had already reported her to Gacaca for looting homes. Charlotte made a similar claim, asserting that she was accused in Gacaca only after giving up a neighbor who went to Kibeho to loot cows. ${ }^{23}$

But not everyone was so untrustworthy. Lori, a survivor of the genocide, told a different story. She left her home in the care of neighbors she knew and trusted, and she found the home intact and untouched when she returned. ${ }^{24}$ While her unusual story is not indicative of the typical progression of events during the genocide, the culture of sharing and ikinyabupfura sometimes held firm. For women rescuers, this sharing even extended to acts of rescue. Their interconnectedness with Tutsi neighbors trumped extremist propaganda and these women provided assistance much as they would during other less-violent times of need.

Women rescuers spoke of acts of rescue during the genocide and they spoke, too, of sharing. Martha hid five Tutsis in her home and elaborated on the circumstances of their rescue. "We used to share the little food we had, we weren't all that wealthy at all, we were very poor, but we shared the little food I had with everyone." ${ }^{25}$ For Martha, rescuing her Tutsi neighbors from harm was not enough. She could not leave them to fend for themselves, nor could she let them starve while they remained in her care. She extended the culture of sharing of food items, a common practice during peaceful times turned unusual in the genocide, as a sign of hospitality and welcome.

Josephine also shared what little food she had with her charges. She noted that this became a point of contention between her and her husband. He argued that her generosity affected their children adversely, and that they deserved preferential treatment. "He was complaining that there is not enough food, look at how the kids now are, they are not in good condition because they are not eating well. The only food we get, we shared it all around. ${ }^{206}$ Still, Josephine persisted in sharing what little she could gather among all the people in her care without discrimination. Later, when she feared her husband would give her up to the authorities in part due to her persistent sharing, she smuggled everyone across the lake to the Democratic Republic of Congo.

When Elana's husband brought home a woman and two children and joked, "Elana, you know what?! I brought more!" she described her next steps without pause. "I had finished taking [eating] ugali [starch porridge] and I had prepared those little remaining and beans. I decided to share it among them." ${ }^{27}$ Elana and her family did not hesitate to risk their lives to protect this family from death. But first and foremost, Elana made sure to share her remaining food with them. 


\section{Sharing post-genocide}

The significance of sharing in post-genocide Rwanda cannot be overstated even today, sharing remains a cultural reference point for friendship, trust, reconciliation, and unity. Yet, occasionally, as the following incident exemplifies, the impact of the genocide is laid bare, revealing frayed, even broken, social norms. Driving in Rwanda can be a precarious experience. Bridges are not well marked and often lack barriers on either side. One evening, just outside Kigali, a car missed a turn and fell nose-first into a steep ditch. The crash drew attention from afar, and enough people ran toward the vehicle that it seemed possible to lift the car out of the ditch and set it back on its course. But instead of providing assistance, everyone milled about, gesticulating animatedly as a few discussed something with the driver. When asked why there was a delay, why the people gathered did not help pull the car out of the ditch, one man laughed, "Of course they are negotiating a price for their help!" In response to the exclamation niba ufite ikinyabupfura, ufasha bila amafaranga, or "if you have ikinyabupfura, you help without money," the man laughed again. Since the genocide, Rwandans no longer have ikinyabupfura, he replied. If this assertion is true, it poses a challenge. How will Rwandans reverse the damage caused by the genocide and repair the rifts in once-unified communities? As was often the case during the genocide, many have turned to the government in search of answers.

As we have seen, many blame bad governance for the genocide that ravaged Rwanda. For example, Nshimyimana elaborated that,

the system used for convincing people to hate others - it was the government. If the government did not participate, I think the genocide would not have been done as it was done. So, it's the hatred, the hatred taught by the government. ${ }^{28}$

Reconciliation thus requires the rejection of the government-endorsed genocidal ideology that dominated the mainstream narrative in 1994 and overturned the prior culture of sharing and interdependence. The government is cognizant of this and adopted two measures, ingando and umuganda ${ }^{29}$ with reunification and re-education in mind.

Ingando, or solidarity camps, were established by the government throughout the country "both to plant the seeds of reconciliation, and to disseminate proRPF ideology through political indoctrination. ${ }^{30}$ Rwandans from all walks of life were encouraged and, in some instances, required to attend ingando "to study government programs, Rwandan history, and unity and reconciliation."”31 Camp sessions last up to several months and are intended to reverse the divisionist ideologies and genocidal mobilization that prevailed. ${ }^{32}$ TIG incarceration camps include a modified version of ingando training as part of their rehabilitation curriculum. While the program has sustained intense criticism from the international community as a practice in pro-RPF propaganda and brainwashing, ingando also emphasizes inter-ethnic unity and cooperation. This focus on the 


\section{Sharing Salt}

peaceful coexistence that preceded colonial rule and shared values, history, culture, myths, and practices has had a positive impact, according to many women perpetrators.

Another practice, umuganda, or mandatory labor, has been re-instituted by the government. The practice and philosophy of umuganda has deep roots in precolonial monarchical rule and a violent history during the genocide. Initially a kingdom-instituted practice of mandatory labor known as uburetwa, it was later manipulated into primarily Hutu forced labor by the Belgian colonialists and later still, albeit in a less exploitative fashion, by President Habyarimana who referred to it as a " "necessary obligation' for all of Rwanda's inhabitants." 33 During the genocide, the regime manipulated the culturally familiar practice of umuganda, collective labor to benefit the community, to compel citizens to participate in murder. Thus, the state used umuganda as a catalyst for widespread killing. ${ }^{34}$ Despite its loaded history, the RPF government decided in 1998 to reclaim and re-define the practice of umuganda as a means of reunifying the Rwandan people.

More recently, on the last Saturday morning of every month, shops close across the country, streets empty of all foot, bicycle, and vehicle traffic, and Rwandans aged 18 to 65 are required to work on a common project identified by the community as necessary for its betterment. Projects vary in scope and size but typically include repairing rain-damaged roads, digging trenches, constructing buildings, or rehabilitating fields for cultivation. Responsibility for the manual labor falls upon community members from all walks of life who work side by side. Once the morning's work is completed, the community comes together to vet future projects, address pressing matters in the neighborhood, and hear announcements from local leaders. Umuganda receives mixed reactions from Rwandans. Some reject it because of the required manual labor; others view it as another government vehicle for pro-RPF propaganda. While these criticisms are salient, still, umuganda has become both an equalizer for community members and a leverage point for state-led unity and reconciliation initiatives.

With these and other measures in place, many government leaders remain optimistic about the future. Aloisea Inyumba cited numerous initiatives, organizations, and cooperative projects dating back to the period immediately after the genocide as proof of unity and reconciliation among Rwandans. ${ }^{35}$ She pointed, for example, to the success of a national shelter program as an affirmative indicator of reunification.

That was also another sign that people were ready to receive the survivors, give them accommodation, give them shelter and food.... It was also highly remarkable since all these program were not discriminatory. People were not asking questions [like] "are you a perpetrator?" [It was] just a national crisis that people were responding to. ${ }^{36}$

At the core of the success of this initiative was sharing, though Inyumba did not use that term. She instead emphasized the Rwandan character of working 
together regardless of ethnic identity or difference. Her focus was on the absence of bitterness or discord among survivors and returnee Tutsis toward Hutus. For her, the fact that Tutsis were willing to provide assistance to the homeless - in other words, share - without discrimination or preference according to ethnicity was a clear sign that the country was rehabilitating.

Sharing among survivors was a necessary component of survival in the wake of the genocidal devastation. Marjorie was safe once she made it to the Nyarushishi camp, but resources were scarce. "Where we were, on the hills, we tried to share what little we had. Those who had more, gave to the poor clothes, building materials." To her, these acts were born of necessity but also symbolized unity and caring. She stressed, "We loved one another a lot." ${ }^{37}$ Survivors banded together and formed a host of organizations, including umbrella groups Survivors Fund (SURF) and IBUKA, to meet short- and long-term needs. Specific organizations were also established to assist particular survivor needs, for example widowed women (Association des Veuves du Genocide, or AVEGA Agahozo), students (Association des Etudiants et Elèves Rescapés Du Génocide, or AERG), and orphans (Association des Orphelins Chefs de Ménages, or AOCM). Still, even with the establishment of survivor aid organizations, resources remained scarce and hardships persisted. After Marjorie returned home, she continued to suffer. "We also have a problem of thieves who attack every night. They steal the harvest and the night watchmen demand a lot of money." Hers is not a unified and inter-connected community, so Marjorie is forced to fend for herself. "I have given up everything. I am content to harvest whatever there is." 38

Some women rescuers experienced vulnerability and insecurity as a result of their actions during the genocide ${ }^{39}$ others noted that their neighbors refused to share with them because of their rescue initiatives. Ruth lamented, "I can't ask anybody even for salt," the most basic of goods. She knew the response she would receive if she asked her community members to share with her. "You can't ask for anything because when you do they are like 'Oh, I thought they [Tutsis] have brought you money." "40 Ruth's neighbors adduced falsehoods about rescuer wealth to justify their parsimony. She feared hosting me at her home for fear of provoking them further and sparking more rumors about her hidden wealth. The belief that rescuers had benefitted financially meant that some rescuers' neighbors no longer shared basic food items and water with them, or boycotted their businesses, thereby causing continued economic harm post-genocide. $^{41}$

For Ruth, the meaning of these actions are clear: Because she rescued, she is not considered a member of the community. While the government seeks to ensure that women are provided equal access to economic opportunities, land, and inheritance, the cooperation and inter-reliance of neighbors is vital to rural communities. When the community ostracizes an individual or family, the outcasts are vulnerable. They cannot rely on their neighbors to support them in instances of crop failure, business failure, illness, or unexpected emergencies. Ostracized and suffering, this isolation is especially felt by women, who are 


\section{Sharing Salt}

often restricted (financially as well as socially) in their ability to relocate to a new community. As a result, Ruth is on her own and no longer benefits from the usual protective measures afforded to a unified community.

Sula gave a blunt analysis of unity and reconciliation in Rwanda. When asked what could be done to achieve these goals, she replied, "Unity and reconciliation? ... Do you really want me to talk about unity and reconciliation?" She burst out laughing.

Let me tell you! Unity and reconciliation! You [a Tutsi] will go and sit there and share a beer [with a Hutu], when you go to the toilette [sic], he/she [Hutu] will put in the poison. When you come back, you drink and die. Me, I won't reconcile with them and share something. ${ }^{42}$

Sula was dubious that government efforts to reconcile the country would be successful. In her mind, reconciliation, and notably sharing, were impossible. Letting down her guard would result in death.

Others described relations in their community using restrained but positive terms. When Allison's community learned she had rescued a young girl, they revered her and celebrated her actions. She depicted relations in her community in glowing terms. "They share, they stay together, you don't see any bad intention or bad tensions around." ${ }^{43}$ Her evaluation was similar when relating the community's reception of her as a woman rescuer. "I don't have any problems, we stay together, we share water, firewood, or anything, we share all these things." Still, despite the warm reception of her and her repeated references to sharing, Allison remained cautious, adding almost as an afterthought, "But you never know what someone has in their heart even when all this is going on." 44

Women incarcerated at TIG camps around the country offered similar expressions of unity and reconciliation. For the most part, the content of these references were uniform, due perhaps to the standardized curriculum taught in every camp that emphasizes these processes. Rebecca gave a glowing review of her time at TIG.

For the last four years I have been here, I've learned so much in terms of understanding how to be and stay together, with even those that I might have hurt in any way. I've learned to share with them, talk to them, share everything, if it's a drink, we share together, basically, to me, I've learned so much. ${ }^{45}$

Learning to share again is one thing; implementing those lessons in day-to-day life another. It remains to be seen if the curriculum learned at TIG will shape Rebecca's behavior after she is released.

Cassie was hopeful that she would repair relations with her community once she completed her sentence. For her, sharing was an integral part of that process.

I will try to mend the relationship with my neighbors and whatever happened, ask for forgiveness, visit each other, share godparents with their children and 
also intermarry and build the new Rwanda completely. Start all over. And stay together. That is my target - this is what I want to do after TIG. ${ }^{46}$

Charlotte had already taken steps to ensure she would reintegrate. During her annual visits home, she enacted the lessons she learned at TIG. She described her existing relations with her community in optimistic terms.

There is no problem - we share everything. If I serve my food early, I can come and share anything. If they have a wedding, I can contribute so the way of living is good. There are even those who escort me up to this place [TIG] ${ }^{47}$

Charlotte was quick to point out that her experience was not unusual. She went on to describe more broadly the state of relations between Hutus and Tutsis in her area.

What I see is the relationship is very good. Tutsis and Hutus live together, they live in harmony, they share everything. If one is sick, the other one would come to rescue and the same applies to the other person. If one is getting married, the other one has to come and contribute in some way. ${ }^{48}$

Charlotte's account of the myriad ways the community shares is promising. But then she continued,

There is a lot of sharing and staying together and living in harmony with each other. In case anyone did not, or refused, to help another person based on ethnicity, then that person would be punished or would be questioned why. Because that is not acceptable in their community. ${ }^{49}$

Beneath this seemingly glowing account of community unity and reconciliation is the threat of punishment. If sharing occurs only as a result of coercive force, then the reconciliation that act embodies is not voluntary and may not be genuine. While actions are of considerable importance, the sentiment behind them must also be considered.

Polly gave a positive, encouraging, assessment of relations in her community in the aftermath of the genocide. "We used to share beer, we used to visit each other, there was no problem! There was no problem even after the genocide!" But when asked if any Tutsi remained in her area during this time, she acknowledged that, "The men are not there, it's only the women. Three men, the others are women, and I don't have any problem." ${ }^{50}$ In her estimation, inter-ethnic relations were perfectly fine, though she did not consider that the survivors were few and almost exclusively women. It is not surprising that the women survivors did their best to get along with their neighbors despite the genocide. ${ }^{51}$ They were doubly vulnerable: as Tutsis in a predominantly Hutu area, and as women in a male-dominated society. Addressing residual tensions, property loss, or injustices would not be possible without incurring additional risk to themselves and surviving family members. 


\section{Sharing Salt}

Having reconciled with the widow of the man she reportedly gave up by accident to killers, Elaine was optimistic about re-integrating into her community. "They are very okay. If I have a wedding, I would send out invitations to everyone, even to the wife [of Protaise]." For Elaine, reconciliation meant sharing in a celebration such as a wedding. Then she goes further. Elaine views herself as complicit in Protaise's death, yet she still manages to enjoy warm relations with his widow. "We share beer, we share drink. It's ok. If one has harvested beans, we share, we bring some and then I would say maybe sweet potatoes I also have and we give each other, we share food and everything., ${ }^{52}$ Elaine not only shares on special occasions with Protaise's widow, she also shares in day-to-day activities like drinking beer together and harvests.

Despite the overwhelmingly positive rhetoric about reconciliation and unity espoused by many women perpetrators, there is cause for concern. Reunifying the country requires utter rejection of the genocidal ideology that upturned the normal social order, and there is evidence that this is not the case for some women perpetrators. Words carry meaning. In Kinyarwanda, many words can be used to describe the same thing and the use of one word over another carries additional weighted meanings. Noted linguist and anthropologist Edward Sapir wrote, "the 'real world' is to a large extent unconsciously built up on the language habits of the group ... We see and hear and otherwise experience very largely as we do because the language habits of our community predispose certain choices of interpretation.." ${ }^{53}$ Professor Benjamin K. Bergen has pondered the link between metaphors and concepts in individual thinking. "It's because you think metaphorically - because you systematically map certain concepts unto others in your mind - that you speak metaphorically. The metaphorical expressions are merely (so to speak) the tip of the iceberg." ${ }^{54}$ When a women perpetrator chooses to use one word or phrase over another, it provides us clues as to her interpretations, inner thinking, and mental mapping.

Following our interview with Valerie Bemeriki, my translator, a survivor, observed that while it was clear that Bemeriki was withholding information and remained defensive, what stood out as especially suspicious was her lexicon. Throughout the interview, Bemeriki repeatedly used the expression ibimenyetso simusiga, or "tangible evidence." A seemingly innocuous phrase, this term carried layers of meaning. It was popular among extremists during the pregenocide period and was used regularly by perpetrators during the genocide to justify targeting Tutsis for discrimination, marginalization and, eventually, annihilation. As a result of its loaded history, the expression is no longer accepted in mainstream society and its current usage is indicative of genocidal ideology on the part of the speaker. That Bemeriki continued to use a term popularized by extremists and used against Tutsis may suggest that she was not the model of rehabilitation she purported to be.

Bemeriki is not alone in this. As we have seen, controversy abounds over the use of intambara (war) over jenocide (genocide), to describe the events of $1994 .^{55}$ This word choice occurred in many interviews with an additional interesting twist. When the women referred to the genocide as intambara, my 
translator automatically translated it into "genocide" in English. When asked why she used the word "genocide" and not "war," she was surprised. She did not realize she was erroneously translating the word as the mapping in her mind identified that term as a synonym for genocide. It was not clear whether most of the women meant "genocide" or "war" when they said intambara. We can only guess as to the mapping in their minds. This is not proof of widespread, persistent genocidal ideology. Still, it is worth considering if, despite the many references to sharing and reconciliation, the post-genocide education and training initiatives are having a meaningful impact on women incarcerated at TIG and in prison.

Just as sharing was the cornerstone for stable rural societies in pre-genocide Rwanda, and a primary indicator of community health and well-being, so too has sharing become elemental to Rwanda's post-genocide reconstruction, and an indicator of post-genocide unity and reconciliation. References to sharing were widespread among community and government stakeholders, survivors, rescuers, and perpetrators. While government officials remain optimistic that the community can mend the social fabric torn apart by the genocide, women rescuers were cautious in their assessment. In addition, survivors focused less on interethnic sharing and more on sharing among themselves. While the repeated references to sharing among women perpetrators is promising, it remains unclear whether that sharing is voluntary or the product of coercive measures. Without voluntary sharing, we cannot be sure that the reconciliation and unity Rwanda seeks is genuine and long-term.

\section{Notes}

1 Philip Gourevitch, We Wish to Inform you that Tomorrow we will be Killed with our Families (New York: Farrar, Straus and Girous, 1998): 34.

2 Interview Emmanuel Nshimyimana, interview by Sara E. Brown, Murambi, Rwanda, 29 June 2011.

3 Interview Odeth Kantengwa, interview by Sara E. Brown, Kigali, Rwanda, 16 June 2011.

4 Phil Clark, "Hybridity, Holism, and Traditional Justice: The Case of the Gacaca Courts in Post-Genocide Rwanda," George Washington International Law Review 39, no. 4 (2007): 818.

5 Interview G 20 “Alexa," interview by Sara E. Brown, Cyungo, Rwanda 17 March 2014.

6 Interview G 18 "Cindy," interview by Sara E. Brown, Jali, Rwanda, 16 February 2014.

7 Interview G 17 "Deena," interview by Sara E. Brown, Jali, Rwanda, 16 February 2014.

8 It is interesting to note that Deena's narrative runs counter to research done on the complicity of the churches in fomenting genocide in Rwanda. For example, see Genocide in Rwanda: Complicity of the Churches? edited by Carol Rittner, John K Roth, and Wendy Whitworth (St. Paul: Paragon House, 2004).

9 Interview G 16 "Laura," interview by Sara E. Brown, Jali, Rwanda, 16 February 2014.

10 Interview G 9 "Lynn," interview by Sara E. Brown, Ngoma, Rwanda, 14 February 2014. 
11 Interview R 5 "Janet," interview by Sara E. Brown, Butare, Rwanda, 20 February 2014.

12 Interview R 4 “Allison,” interview by Sara E. Brown, Butare, Rwanda, 20 February 2014.

13 Interview R 8, S 6 "Beth,” interview by Sara E. Brown, Kibuye, Rwanda, 22 February 2014.

14 KGMC Interview K 4 "Julian Nyirabatumwa," retrieved in Kigali, Rwanda, February 2014.

15 As noted in Chapter 5, "Perpetrators," Category 3 crimes include a person who only committed an offense related to property. However, when the offender and the victim come to a settlement by themselves, settle the matter before the authorities or before the witnesses before the commencement of this law, the offender shall not be prosecuted.

16 Evelyn Gertz, Hollie Nyseth Brehm, and Sara E. Brown, "Women Perpetrators: Theorizing Gender and Genocide." In Perpetrators: Dynamics, Motivations, and Conceptsfor Participating in Mass Violence, edited by Timothy Williams and Susanne Buckley-Zistel (forthcoming).

17 Ibid.

18 AVEGA interview A 4 "Gabriella," retrieved in Kigali, June 2011.

19 AVEGA interview A 3 "Marjorie," retrieved in Kigali, June 2011.

20 AVEGA interview A 7 "Meredith," retrieved in Kigali, June 2011.

21 AVEGA interview A 13 "Jamie," retrieved in Kigali, June 2011.

22 Interview G 14 "Kathleen," interview by Sara E. Brown, Ngororero, Rwanda, 21 February 2014.

23 Interview G 19 "Charlotte," interview by Sara E. Brown, Jali, Rwanda, 16 February 2014.

24 AVEGA interview A 6 "Lori," retrieved in Kigali, Rwanda, June 2011.

25 Interview R 12 "Martha," interview by Sara E. Brown, Gasabo, Rwanda, 24 April 2014.

26 Interview R 6 Josephine Dusabimana, interview by Sara E. Brown, Kibuye, Rwanda, 20 February 2014.

27 Interview R 10 "Elana," interview by Sara E. Brown, Rwamagana, Rwanda, 18 March 2014.

28 Interview Emmanuel Nshimyimana.

29 Both ingando and umuganda have been widely criticized by scholars critical of the RPF government, who view the programs as part of state-led efforts to control and forcibly indoctrinate the populace. For example, see portions of Remaking Rwanda: State Building and Human Rights after Mass Violence, edited by Scott Straus and Lars Waldorf.

30 Chi Mgbako, "Ingando Solidarity Camps: Reconciliation and Political Indoctrination in Post-Genocide Rwanda," Harvard Human Rights Journal 18 (2005): 202.

31 Ibid.

32 See Chapter 3, "Mobilization."

33 Scott Straus, The Order of Genocide: Race, Power, and War in Rwanda (Ithaca, NY: Cornell University Press, 2006): 218. For more on the pre-colonial, colonial, and postcolonial forms of uburetwa and umuganda, see inter alia Alison Des Forges and David S. Newbury, Defeat is the Only Bad News: Rwanda under Musinga, 1896-1931 (Madison: The University of Wisconsin Press, 2011); Des Forges' Leave None to the Tell the Story: Genocide in Rwanda (New York: Human Rights Watch, 1999); and Jan Vansina's Antecedents to Modern Rwanda: The Nyiginya Kingdom (Madison: University of Wisconsin Press, 2004).

34 See Chapter 4, "Rescuers."

35 See the Chapter 6, "Post-Genocide Trajectories," for some examples.

36 Interview Aloisea Inyumba, interview by Sara E. Brown, Kigali, Rwanda, 7 June 2011. 
37 AVEGA Interview A 3 "Marjorie."

38 Ibid.

39 See Chapters 4, "Rescuers" and 6, "Post-Genocide Trajectories."

40 Interview R 7 "Ruth," interview by Sara E. Brown, Kibuye, Rwanda, 22 February 2014.

41 Ibid. This phenomena was documented by "The Rescuers" project run by PROOF: Media for Social Justice, viewed while on display in Sarajevo, Bosnia-Herzegovina, July 2011.

42 KGMC interview K 1 "Sula Karuhimbi," retrieved in Kigali, Rwanda, February 2014."

43 Interview R 4 "Allison."

44 Ibid.

45 Interview G 1 "Rebecca," interview by Sara E. Brown, Muhanga, Rwanda, 30 June 2011.

46 Interview G 8 “Cassie," interview by Sara E. Brown, Ngoma, Rwanda, 14 February 2014.

47 Interview G 19 "Charlotte."

48 Ibid.

49 Ibid.

50 Interview G 26 "Polly," interview by Sara E. Brown, Rwamagana, Rwanda, 14 April 2014.

51 See Chapters 4, "Rescuers" and 6, "Post-Genocide Trajectories" for discussions on women's vulnerability.

52 Interview G 13 "Elaine," interview by Sara E. Brown, Ngororero, Rwanda, 21 February 2014.

53 Edward Sapir, "The Status of Linguistics as a Science." In Culture, Language, and Personality: Selected Essays, edited by David G. Mandelbaum (Berkeley: University of California Press, 1949): 69.

54 Benjamin K. Bergen, "Metaphors are in the Mind." In This Explains Everything: Deep, Beautiful, and Elegant Theories of How the World Works, edited by John Brockman (New York: Harper Perennial, 2013): 220.

55 See Chapter 1, "Finding the Right Flashlight."

\section{References}

AVEGA interview A 3 "Marjorie.” Retrieved in Kigali, June 2011.

AVEGA interview A 4 "Gabriella." Retrieved in Kigali, June 2011.

AVEGA interview A 6 "Lori." Retrieved in Kigali, Rwanda, June 2011.

AVEGA interview A 7 "Meredith.” Retrieved in Kigali, June 2011.

AVEGA interview A 13 "Jamie." Retrieved in Kigali, June 2011.

Bergen, Benjamin K. "Metaphors are in the Mind." In This Explains Everything: Deep, Beautiful, and Elegant Theories of How the World Works, edited by John Brockman, 218-20 (New York: Harper Perennial, 2013).

Clark, Phil. "Hybridity, Holism, and Traditional Justice: The Case of the Gacaca Courts in Post-Genocide Rwanda." George Washington International Law Review 39, no. 4 (2007): 765-838.

Gertz, Evelyn, Hollie Nyseth Brehm, and Sara E. Brown. "Women Perpetrators: Theorizing Gender and Genocide." In Perpetrators: Dynamics, Motivations, and Concepts for Participating in Mass Violence, edited by Timothy Williams and Susanne BuckleyZistel (forthcoming).

Gourevitch, Philip. We Wish to Inform you that Tomorrow we will be Killed with our Families (New York: Farrar, Straus and Girous, 1998). 
Interview Aloisea Inyumba. Interview by Sara E. Brown. Kigali, Rwanda, 7 June 2011. Interview Emmanuel Nshimyimana. Interview by Sara E. Brown. Murambi, Rwanda, 29 June 2011.

Interview G 1 "Rebecca.” Interview by Sara E. Brown. Muhanga, Rwanda, 30 June 2011. Interview G 8 "Cassie." Interview by Sara E. Brown. Ngoma, Rwanda, 14 February 2014.

Interview G 9 “Lynn.” Interview by Sara E. Brown. Ngoma, Rwanda, 14 February 2014.

Interview G 13 "Elaine." Interview by Sara E. Brown. Ngororero, Rwanda, 21 February 2014.

Interview G 14 "Kathleen.” Interview by Sara E. Brown. Ngororero, Rwanda, 21 February 2014.

Interview G 16 "Laura.” Interview by Sara E. Brown, Jali, Rwanda, 16 February 2014.

Interview G 17 "Deena.” Interview by Sara E. Brown. Jali, Rwanda, 16 February 2014.

Interview G 18 “Cindy.” Interview by Sara E. Brown. Jali, Rwanda, 16 February 2014.

Interview G 19 "Charlotte." Interview by Sara E. Brown. Jali, Rwanda, 16 February 2014.

Interview G 20 “Alexa.” Interview by Sara E. Brown. Cyungo, Rwanda, 17 March 2014.

Interview G 26 "Polly." Interview by Sara E. Brown. Rwamagana, Rwanda, 14 April 2014.

Interview Odeth Kantengwa. Interview by Sara E. Brown. Kigali, Rwanda, 16 June 2011.

Interview R 4 “Allison." Interview by Sara E. Brown. Butare, Rwanda, 20 February 2014.

Interview R 5 “Janet.” Interview by Sara E. Brown. Kibuye, Rwanda, 20 February 2014.

Interview R 6 Josephine Dusabimana. Interview by Sara E. Brown. Kibuye, Rwanda, 20 February 2014.

Interview R 7 "Ruth.” Interview by Sara E. Brown. Kibuye, Rwanda, 22 February 2014.

Interview R 8, S 6 "Beth." Interview by Sara E. Brown. Kibuye, Rwanda, 22 February 2014.

Interview R 10 "Elana.” Interview by Sara E. Brown. Rwamagana, Rwanda, 18 March 2014.

Interview R 12 “Martha.” Interview by Sara E. Brown. Gasabo, Rwanda, 24 April 2014.

KGMC interview K 1 "Sula Karuhimbi." Retrieved in Kigali, Rwanda, February 2014.

KGMC interview K 4 "Julian Nyirabatumwa." Retrieved in Kigali, Rwanda, February 2014.

Mgbako, Chi. "Ingando Solidarity Camps: Reconciliation and Political Indoctrination in Post-Genocide Rwanda." Harvard Human Rights Journal 18 (2005): 201-224.

Sapir, Edward. "The Status of Linguistics as a Science." In Culture, Language, and Personality: Selected Essays, edited by David G. Mandelbaum (Berkeley: University of California Press, 1949).

Straus, Scott. The Order of Genocide: Race, Power, and War in Rwanda (Ithaca, NY: Cornell University Press, 2006). 


\section{Epilogue}

My first visit to Rwanda coincided with the tenth commemoration of the 1994 genocide. Ten years and several trips later, I returned, this time for Kwibuka20, the twentieth anniversary commemoration of the genocide. Rwanda launched Kwibuka20 on 7 January 2014, a national and international initiative to commemorate the anniversary. Over 250 scholars, officials, activists, and diplomats sat in attendance at the Kigali Genocide Memorial for the lighting of the Urumuri Rutazima, Rwanda's Flame of Remembrance. For the next three months, leading up to the official commemoration period beginning on 7 April, Kwibuka20 organizers ${ }^{1}$ hosted, coordinated, and publicized commemoration activities and programs in Rwanda and around the world. Combining a diverse social media platform with culturally traditional symbols and rituals, Kwibuka20 was intended to represent a new era in genocide commemoration that merged modern technology and memorialization practices with the traditional elements popularized in prior years.

Tens of thousands of people filled Amahoro Stadium on 7 April 2014. Soon after the program began, a survivor was invited to the center stage in the middle of the field to recount his testimony. Despite modern adaptations, key traditional elements were present, including public testimonies of personal experiences of victimization, survival, and rescue during the genocide. ${ }^{2}$ As the first survivor began to recount his experiences during the genocide to the audience at Amahoro Stadium, a woman in the crowd began to cry out. Another scream came from another section. Soon the stadium filled with the sounds of shrieking men and women, some muffled, some echoing off the walls of the stadium. The survivor at the center stage continued to recount the horrors he lived through without pause, as did the speakers who followed him. Mothers called out the names of children, others screamed until they ran out of breath before starting anew, still others cried out incomprehensibly. Many visiting dignitaries present at their first commemoration in Rwanda were visibly shaken, but for those who had attended in past years, this served as a poignant reminder that while much has changed in Rwanda, much has remained the same.

The 2014 commemoration reflected Rwanda's post-genocide reconstruction and rehabilitation over the past two decades: a revolutionary dynamism on the one hand, and a sometimes dichotomous attachment to pre-1994 patterns of 


\section{Epilogue}

thought and practice on the other. Rwanda has taken enormous strides toward reconciling the country, embracing measures and implementing initiatives that have contributed to its security, steady economic growth, and rapid development. Still, Rwanda has not yet managed to fully incorporate the history of women's agency into its mainstream narrative, nor society's memory of past experiences.

In 1994, extremist-controlled media, government propaganda, and local leaders created an atmosphere of fear and tension before the genocide. The mass media, controlled by extremist elements in society and the state, disseminated messages of fear and divisionism that mobilized Hutu men and women against their Tutsi neighbors. Thus, when Habyarimana's plane was shot out of the sky on 6 April 1994, the stage had been carefully set and the actors strategically placed to facilitate genocide. However, some women refused to heed the call to murder and instead chose another path. The myriad of actions undertaken during the genocide and variety of motivations that compelled these women to rescue, often with deadly consequences in the event of discovery, is informative, providing the first glimmers of a replicable blueprint for developing a new generation of upstanders.

A nationwide formalized mechanism for identifying women (and men) who rescued others during the genocide would benefit the historical record as well as the nation's efforts to rebuild. Elucidating the complicated story of women rescuers during the genocide in Rwanda would also assist efforts to accurately document, learn from, and prevent mass violence. Additionally, identifying more rescuers who could serve as peace brokers would benefit Rwanda's efforts to unify the country.

At the same time, Rwanda would be well served to acknowledge and mainstream the Rwandan women who participated in the destruction of their Tutsi compatriots, as well as the broad range of activities that comprise direct and indirect acts of violence. Their participation and relative anonymity following the end of the genocide serve as a cautionary tale and lesson not just for Rwanda's next generation, but also for future post-conflict reconstruction and rehabilitation initiatives. And expanding the prevailing conversation on agency and perpetration to include women's constrained agency and indirect acts of violence is a critical component. Lastly, omissions in the academic community, which has also largely overlooked the women who participated in the genocide, have a deleterious effect on the overall narrative. ${ }^{3}$ Scrutinizing and studying women rescuers and perpetrators would help overcome the women-as-victims or womenas-bystanders categories academia so often forces upon women.

It is possible that many of these necessary changes will come from the women of Rwanda who have consciously and proactively prioritized gender mainstreaming and gender-equality initiatives. Many women are up to the task. One survivor, Marjorie, insisted that the widowed survivors of the genocide "must not be like butterflies ... we must be sure of ourselves, that no one will intimidate us, that no one will dishonor us." "Rwanda Parliament member Connie Bwiza knew inclusive rights for men and women was a necessity when 
she joined the transitional parliament in 1999, asserting, "You can never talk about democratic governance when you have a part of the society left behind - over 50 per cent women are the Rwandan society members."5 Rosine Urujeni, the director of a non-profit, concurred, noting that while more women became involved in business post-genocide, "It's not because women couldn't do it before, it's because they weren't given the opportunity to go into it before." ${ }^{6}$ These women do not assume equal rights will come to them; they proactively make certain that they receive them. And they may be the ones to ensure Rwanda adapts its historical record to include the role of women during its most painful chapter.

More than 20 years after genocide decimated Rwanda, Gender and the Genocide in Rwanda: Women as Rescuers and Perpetrators tells the history of women who not only experienced it, but also participated in it. Documenting their mobilization and militarization pre-genocide, their participation either as rescuers or as perpetrators during the genocide, and their post-genocide trajectories, Gender and the Genocide in Rwanda adds another layer to Rwanda's evolving narrative. Rwanda is engaged in a dynamic process of reconstruction and rehabilitation that includes not only the physical apparatuses of the country, but also the country's national identity, collective memory, and ethos. The role of women is elemental to this process and to Rwanda's future success. In order to be part of Rwanda's future, women must first be accurately represented in its past.

\section{Notes}

1 Ever the participant-observer, I assisted as a volunteer during the Kwibuka20 commemoration and accompanying Kigali International Forum.

2 The survivors selected to recount their testimony were limited, however. After a number of public mishaps, women who experienced sexual violence during the genocide are no longer asked to give public testimony. Their experiences have proved too traumatizing for the broader audience. As a result, women survivors invited to give their narratives before an audience are restricted.

3 For example, when addressing the crowded Hutu-majority refugee camps that dotted Rwanda's border with the Democratic Republic of the Congo post-genocide, African studies and government expert Catherine Newbury asserted that,

moreover, the majority of refugees in the camps were women and children who were neither major perpetrators of the genocide nor a military threat. In the Goma area, for example, 80 percent of the people in the camps were women and children.

While the demographic breakdown of the camps may constitute an accurate observation, the assumptions drawn from those statistics speak to a gendered frame of analysis that erroneously overlooks women's participation in the Rwandan genocide. See her article "Ethnicity and the Politics of History in Rwanda," Africa Today 45, no. 1 (1998): 7-24.

4 AVEGA interview A 3 "Marjorie," retrieved in Kigali, June 2011.

5 Interview Connie Bwiza, interview by Sara E. Brown, Kigali, Rwanda, 4 August 2014.

6 Interview Rosine Urujeni, interview by Sara E. Brown, Kigali, Rwanda, 3 August 2014. 


\section{Epilogue}

\section{References}

AVEGA interview A 3 “Marjorie.” Retrieved in Kigali, June 2011.

Interview Connie Bwiza. Interview by Sara E. Brown. Kigali, Rwanda, 4 August 2014.

Interview Rosine Urujeni. Interview by Sara E. Brown. Kigali, Rwanda, 3 August 2014.

Newbury, Catherine. "Ethnicity and the Politics of History in Rwanda." Africa Today 45, no. 1 (1998): 7-24. 


\section{Appendix A}

\section{Ethnographic interview questions for community and government stakeholders}

\section{General biographical information}

- What is your age?

- Which region are you from?

- Did you grow up in Rwanda or did you live outside of Rwanda at any time?

- Did you go to school? How many years of schooling did you receive?

- Do you work?

\section{Genocide-specific questions}

I'm going to ask you some questions regarding the genocide.

- Did you experience the 1994 genocide?

If yes, the following questions are asked:

- What was the environment like in Rwanda leading up to the genocide?

- Were there tensions in your area?

- Please describe your experience.

- Did you see women participating?

- If yes, in what capacity were women participating?

- Did you see or experience women rescuing others? If yes, please describe in detail.

- Did you see or experience women perpetrating crimes? If yes, please describe in detail.

\section{Work specific}

Please describe your organization for me.

Who is your beneficiary population? 


\section{Appendix A}

Do you work with genocide survivors, witnesses, rescuers, or perpetrators?

Did your organization exist before the genocide?

What has your work entailed following the genocide?

In your culture, is it normal for women to participate in acts of violence?

In your culture, is it normal for women to participate in acts of rescue?

In your work, do you deal with women who participated in the genocide?

- If yes, how did they participate?

- If perpetrators, do you believe that Gacaca, the National Courts, and the ICTR tried all of the women who perpetrated crimes during the genocide? Please explain your answer.

Do you think that the role of women during the genocide is discussed openly? Please explain.

Should more research be done to determine the role of women during the genocide? Please explain.

Today, how would you describe the situation in Rwanda?

Are there tensions between Hutus and Tutsis?

Do you believe that a recurrence of violence could occur?

Do you feel safe? 


\section{Appendix B}

\section{Semi-structured interview questions for individuals who are survivors, witnesses, rescuers, or perpetrators}

\section{General biographical information}

What is your age?

Which region are you from?

Did you grow up in Rwanda or did you live outside of Rwanda at any time?

Did you go to school? How many years of schooling did you receive?

Do you work?

\section{Genocide-specific questions}

General: I'm going to ask you some questions regarding the genocide.

Did you experience the 1994 genocide?

If yes, the following questions are asked:

- What was the environment like in Rwanda leading up to the genocide?

- Were there tensions in your area?

- Please describe your experience.

For rescuers/perpetrators: Did you participate in the genocide?

If yes, the following questions are asked:

- Please detail your participation.

- Did you rescue?

If yes, the following questions are asked:

- Who did you rescue?

- How did you rescue them?

- Why did you rescue?

- Did you perpetrate crimes? 
If yes, the following questions are asked:

- Were you tried by Gacaca or the National Courts?

- If accused, what were you accused of?

- Were you found guilty?

- If found guilty, what type of sentence did you serve?

- Do you believe you are guilty of these crimes?

- If yes, why did you perpetrate these crimes?

General: Did you see women participating?

If yes, in what capacity were women participating?

Did you see or experience women rescuing others?

If yes, please describe in detail.

Did you see or experience women perpetrating crimes?

If yes, please describe in detail.

\section{Post-genocide questions}

I want to ask you questions related to what happened after the genocide.

After the genocide, where did you go? Did you stay at home or did you move? If you moved, why did you move?

What was life like after the genocide?

- $\quad$ Did you marry?

- Did you have children?

- Did you go back to school?

- Did you work?

- Who were your neighbors?

- Was your community "mixed," with Tutsis and Hutus living together?

- If yes, were there tensions?

If the subject answered yes to having rescued and/or perpetrated crimes during the genocide, the following questions are asked:

- After the genocide, were your actions committed during the genocide recognized?

- If yes, when?

- By whom?

- Why?

- Were you comfortable with this recognition?

- If no, why were you not recognized?

Today, how do you feel about relations between Hutus and Tutsis?

Do you feel safe?

Do you think that a genocide could happen again? 


\section{Glossary}

Akazu Meaning "little house;" a network that enjoyed positions of power in business and government, closely linked to President Juvenile Habyarimana and his wife, Agathe.

Forces Armées Rwandaises (FAR) Rwanda's national army under President Juvenile Habyarimana.

Gacaca courts (Inkiko Gacaca) A hybrid court grounded in a traditional conflict-resolution process familiar to Rwandans that incorporates modern western judicial systems.

Hutu Manifesto (also known as "The Manifesto of the Bahutu" and "Note on the Social Aspect of the Racial Native Problem in Rwanda") 1957 document drafted by nine Hutu intellectuals and submitted to the United Nations decolonization mission that denounced Tutsi domination and called for popular rule.

Ingando Solidarity camps established by the government throughout the country after the genocide.

Interahamwe Killing militias active during the genocide in Rwanda; many received training prior to the start of genocide under the pretense of defending neighborhoods and tracking down infiltrators.

Inyangamugayo Elected members of the community who served as Gacaca court judges.

Kangura A popular print periodical that served as the mouthpiece for Hutu extremists.

Mise au Point (Clarification) 1957 document drafted by the King's court and submitted to the United Nations decolonization mission that called for a transfer of power from the Belgians to the Tutsi king and his council.

Radio Télévision Libre des Mille Collines (RTLM) A popular radio station that served as the mouthpiece for Hutu extremists.

Rwandan Patriotic Front (RPF) A rebel group formed by Tutsi exiles that invaded Rwanda from Uganda in October 1990. After the genocide, the RPF became a prominent political party in Rwanda.

Umuganda Mandatory voluntary labor that was instituted by Rwanda's precolonial monarchy and modified to fit the needs of colonialists and, later, those of the government. In its current form, it includes mandatory countrywide collective labor on a monthly basis and usually addresses a common project identified by the community as necessary for its betterment. 


\section{Index}

Ackerly, B. 7

Adichie, C.N. 8

Adler, R.N. 6

African Rights 9, 127

agency 5; attitudes to 9; constraint of 7, 39,

44-5; defining 16; denial of 6-7, 33;

expression of 44; and faith 79;

perpetrators $102-5$

Agnes 99

Ahishakiye, N. 137-8

Alexa 112, 146

Allison 79, 129-30, 132, 134, 135, 147, 154

altruism 60

Amahoro Stadium 161

Amanda 59, 134

Amy 105

anonymity $110-11,123$

Article 7329

Arusha Accords 34

Askin, K.D. 122

Association des Etudiants et Elèves

Rescapés Du Génocide (AERG) 46, 49, 153

Association des Orphelins Chefs de

Ménage (AOCM) 153

Association des Veuves du Genocide

(AVEGA) 153

Association for the Defense of Women and

Children's Rights (HAGARUKA) 32

Baines, E. 5

balance of power 27

Barayagwiza, J.-B. 45

Barnett, V. 7

Bauer, Y. 10

Belgian colonialism see colonization

Belgian invasion 1896 25-6

Bemeriki, Valerie 46-7, 53, 100-2, 103, 156
Bergen, B.K. 156

Beth 67-8, 74, 133, 147-8

Bikesha, D. 128-9

Bikindi, S. 47

Bjørnlund, M. 45

Blee, K. 6

book: contribution 9; method 5-6; narrative structure $2-3$; overview 1 ; questions asked 2; recommendations 162; summary and conclusion 163

Browning, C. 10

business, women in 163

Butler, J. 43

Bwiza, C. 162-3

bystanders $16,65-6,77$

Cassie 102, 136-7, 154-5

Category 2 offenders 94

Catholic Church 30, 31

Charles 60, 98-9

Charlotte 105-6, 150, 155

chastity 43

children, parental influence 136-7

choice, rescuers 78

choiceless choices 65

Chrétien, J.P. 23, 33

Christian evangelism 23, 28-9

Christianity 71,79

Cindy 50, 51, 99-100, 146, 147

Clark, P. 146

Clementine 83

clientship relationships 24

Coalition pour la Défense de la République (CDR) 106

Cockburn, C. 5, 130

cockroaches 46, 49, 50, 52, 53

Cohen, S. 124

Cohn, C. 96

collective violence 99-100 
colonization 23, 26-8; legacy of 7, 31

Comités de Salut Public 33

commemoration 161-2

communities: helping 145; see also sharing

community, sense of 80

comparative historical approach 10

constructivism 11

continuum of violence 130

convention, violation of 110-11

coup d'état 32

culture-coded racism 26

Davis, N.Y. 40

decision-making 65

decolonization mission 29

Deena 107, 110, 125-6, 146, 149-50

definitions 16-17

Degni-Ségui, R. 2

denial, perpetrators $105-13$

Denise 76-7, 78, 81, 82-3, 132, 135

Des Forges, A. 24, 28, 41-2, 46, 47

destruction 148-9

dictatorship 32

differences, differentiating 40

direct violence 95, 96-9

disclosure, and reluctance 14-15

"Do not let yourselves be invaded" speech 49

domestic space, gendered demarcation 73

Durkheim, E. 11, 60

Dusabimana, Josephine 47-8, 69-70, 74-5, 78-9, 132, 134, 150

Dwork, D. 60

Dworkin, A. 7

education: as divisive 27,79 ; as catalyst for rescue 82-3; participants' 12-13

Elaine 103, 149-50, 156

Elana 59, 61, 134, 150

elections 2013122

Emmanuel 68-9

Enloe, C. 5, 6, 39, 44, 60, 110

epilogue 161-3

Esoteric Code 24, 25

ethnic-based atrocities 29

ethnic categories, and roles 24

ethnic divisions 30,33

ethnicity: identification of 28; and response to rescue 129-30; as shared identity 40 ; and sharing 146-7

family culture, rescuers $81-3$

FAR 34 fear: gendered 43; mobilization and militarization 50-3; perpetrators 103 , 104; post-genocide $130-1$

feminist analysis 9

feminist theory $5-7,10-11$

Forongo, J. 97

France 32

Friedlander, S. 96

friendship, rescuers 80

Fujii, L.A. 48

Gabriella 149

Gacaca courts 12, 15, 91-4, 127-8; aims 92; convictions 148-9, 148, 149; gender 93; model 92-3; origins 91-2; statistics 93; see also post-genocide trajectories

Gasanabo, J.-D. 79

Gashumba, C. 64

gender: Gacaca courts 93; performance of 43; as shared identity 40

gender analysis, value of 5

gender blindness 124

gender mythology 121

gender norms: post-genocide trajectories 138-9; rescuers 72-7

gendered isolation 102

gendered lens, effects of 6

gendered perspective, post-genocide 127

gendered roles, mobilization and militarization 39

genocidal ideology $34-5$

Genocide Archive of Rwanda 110, 129

genocide, defining 16

Gentry, C. 7, 9-10, 111, 121

German colonization see colonization

German Protectorate 26

Globerman, J. 10

Gloria 128

Gobineau, Arthur de 26

Golda 61, 79, 80

Gourevitch, P. 34, 43, 145-6

government, blame 147

grounded theory 11-12, 16

group identity 40

groups, valorization of 44

Gurr, T.R. 10, 40

Habyarimana, J. 31, 32, 34, 152, 162

Hamitic myth 26-7, 49

Harff, B. 10, 40

Harrison, S. 51

Hatzfeld, J. 8, 110, 135

helping 145; see also sharing

High Council 30 
historical context 10

history: Belgian rule 27; colonization 23, 26-8; context and overview 23; coup d'état 32; dictatorship 32; ethnic-based atrocities 29; ethnic categories and roles 24; ethnic divisions 30, 33; genocidal ideology 34-5; German Protectorate 26; government reform 30 ; ID cards 71 ; independence $30-2$; independence movement 29-30; invasion 1896 25-6; legacy of colonization 31 ; monarchy 23-5; notions of racial superiority 26 ; post-World War II 29; power struggle 25; power vacuum 25; pre-colonial 23, 24; revolution 1959 30; role of Catholic Church 30, 31; Rwabugira 25; social structure 26-7; socially divisive policies 26-8; ties with France 32; Tutsi invasion 33-4; women's violence 33; world wars 29

Holocaust, rescuers 41, 60

Horovitz, S. 92

Hotel Rwanda 94

Human Rights Watch 44

humanity, rescuers $80-1$

husbands, role of 73-6

"Hutu Ten Commandments" 42-5, 46, 97

hyper-sexualization 7, 43-4

ibimenyetso simusiga, use of phrase 156

IBUKA 12, 129, 134, 153

identification mechanism 12, 60, 162

identity: construction and maintenance 11 ; duality of 65 ; ethnic divisions 30 ;

fluidity 24 ; group 40 ; shaping 39 ; shared 40

ideology: genocidal 34-5; transmission of 136-7

ikinyabupfura 145, 148, 150, 151

Imandwa belief system 28-9

imprisonments, post-genocide 123, 126

independence $30-2$

independence movement 29-30

indirect rule 27

indirect violence 95, 99-102

individualism, of rescuers 59-60

infrastructure damage 123, 152

ingando $151-2$

Interahamwe $34,62,64,66,67,68,71,76$, $78,82-3,99,102,104-5,108$; gender norms 73 ; recruitment $72-3$

international aid, post-genocide $124-5$

international community, gender blindness 124
International Criminal Tribunal for Rwanda (ICTR) 45, 91, 100

interviews 11, 12; questions asked 165-6, 167-8; scope of responses 40-1; semistructured 13-14

invasion $189625-6$

invisibility 7

Inyumba, A. 123-4, 152-3

Islam 71

isolation $102,153-4$

Jamie 149

Jane $70-1$

Janet 48-9, 79-80, 132-3, 134, 147

Jean 83

Jennifer 103

Joan $61,71,130,135$

Josephine 47-8, 69-70, 74-5, 78-9, 132, 134,150

Julian 63-4, 66, 81-2

Julie $127-8$

justice: post-genocide 125-9; rescuers 81

justice system 92; see also Gacaca courts and International Criminal Tribunal for Rwanda (ICTR)

Kagame, P. 136

Kaitesi, U. 93

Kandt, R. 23, 25, 26

Kangura 41-2, 43, 51

Kanjogera 25, 28

Kantengwa, O. 95, 136, 146

Kantengwa, Prudence 122

Kanzina, A. (Habyarimana) 32, 34

Kapila, M. 137

Karuhimbi, Sula 71, 83

Kathleen 50, 108-9, 126, 149

Kayibanda, G. 31-2

Kayirere, O. 95

Kigali Genocide Memorial 129

Kinyarwanda language 16

kirazira 77

knowledge: local 69-72; supernatural 71-2; uncomfortable 124

Koonz, C. 6

Kristen 50, 91, 94, 99, 102, 106, 113, 150

Krosell, A. 7

Kwibuka20 161-2

Langer, L.L. 65

language 14; choice of 156-7; and education 27 ; meaning of 156 ; metaphors 156; and terminology 16

Laura 107-8, 146 
Learning From History 129

legal records, availability 15

Lemarchand, R. 31, 43

Levi, P. 111

liberal history 23

liberation, by war 44-5

literacy 41

literature, limitations 2

"little house" network 32

local knowledge, rescuers 69-72

local leadership, role of 48-50

Longman, T. 27, 32

looting 149

Lori 150

Lower, W. 6

Loyle, C. 10

Lucy 113

Lynn 46, 147

MacKinnon, C. 7

Mamdani, M. 8, 27, 31, 43

mandatory labor 152 see also umuganda

Margaret 64-5, 66, 133

marginalization, of rescuers 129

Marjorie 50-1, 149, 153, 162

Martha 62-3, 66, 73, 82, 131-2, 150

Mathilde 65-6, 81

Mazurana, D. 127

McKay, S. 127

media: and fear 51; message 52; print publications $41-5,51,52$; radio 41 , $45-8,51,52-3,100$; trials 45

meetings 11

memory, lapses 14-15

men and boys, as rape victims 97-9

Meredith 149

metaphors, and thinking 156

method 5-6

methodology 11-15; challenges 14-15; data sources 11,15 ; interviews 12 ; language 14, 16; modified grounded theory 11-12, 16; participant criteria 11-12; participant identification and contact 15; reluctance to disclose 14-15; researcher effect 13; researcher role 15; role of translators 13; sampling 11-12, 15; semi-structured interviews 13-14; triangulation 12,15

Mibenge, C.S. 127

militarization 39; see also mobilization and militarization

Mise au Point 29

mobility, limited 103

mobilization and militarization: and agency 39; context and overview 39; effects of 41 ; factors affecting $40-1$; fear 50-3; and gendered roles 39 ; and identity 39; local leadership 48-50; preconditions 40; print publications $41-5$; radio $45-8$

modesty 43

modified grounded theory 11-12, 16 monarchy 23-5; of the Mwami 24-31

Moshman, D. 6

motherhood, rescuers 79

motivations: combined factors $81-2$; effects of education 82-3; family culture 81-3; friendship 80; humanity $80-1$; justice 81 ; motherhood 79 ; narrative similarity 83-4; religion 77-9; rescuers 77-83; sense of community 80

Mouvement Républicain National pour la Démocratie et le Développement (MRNDD) 32, 41

Mouvement Révolutionnaire National pour la Démocratie et le Développement (MRNDD) 32, 49

Mouvement Révolutionnaire National pour le Développement (MRND) 41

Mugesera, L. 49; "Do not let yourselves be invaded" speech 49

Mukobwajana, M.L. 53

Munyenyezi, Beatrice 121-3

Murambi 64

music 47

Musinga 26

Mutari 30

Mwami 23, 24

myths, about women 121

Nahimana, F. 45

narratives: reliability 96-7; restraint on 9; similarity 83-4

Nathan 42, 47, 97

national shelter program 152-3

Ndiyeze, O. 110-11

Ngeze, H. 42, 43, 44

Nicole 73, 132

normalization, of violence 7

Nshimyimana, E. 111, 146, 151

Ntahobali, Arsène Shalom 121

Nyabingi 71-2

Nyiramasuhuko, Pauline 9-10, 100, 111, 121

Ofer, D. 9

Oliner, S. and P. 7, 41

onlookers 91 
oral histories 11, 13

oral testimonies 11

orphans, post-genocide trajectories 123-4

othering 7

pacificism, myth of 6-7

parents, transmission of ideology 136-7

participant criteria $11-12$

participants: identification and contact 15; overview 12; overview of perpetrators 12-13; overview of rescuers 13 ; risks for $109-10$

paternalism 28-9, 31

patriarchy 24, 31, 39, 62

Patty 74

performance, of gender 43

perpetrators: actions $94-5$; anonymity

110-11; asking for gifts 110; categories

95; collective violence 99-100; context and overview 94-5; defining 16-17; denial 105-13; direct violence 96-9; fear 103, 104, 109-10; gendered assumptions 110-11; indirect violence 99-102; interviewees 94; justice and punishment 125-9; limited mobility 103 ; locating 60 ; men 110; nature of violence 95 ; omissions 107; overview 12-13; position as women 102-3; position of researchers 96; rape 97-9; reliability of narratives 96-7; reluctance to disclose 14-15; remorse 112-13; repercussions for 135-7; representation of 111-12; summary and conclusions 113-14; traumatization 137; violation of convention 110-11; voluntary agency 102-5

Pettman, J.J. 7

Pieterse, N. 136

Pio 110

political parties $34,48-9$

politics, shift in women's roles $122-3$

Polly 155

Portelli, A. 14

post-genocide trajectories: academic studies 127 ; anonymity and recognition 123-4; dealing with violence 123 ; fear 130-1; gender norms 138-9; gendered perspective 127; government reform 123; hopes 154-5; imprisonments 123 , 126; international aid 124-5; justice 125-9; Munyenyezi case 121-3; orphans 123-4; punishment 125-9; repercussions for perpetrators 135-7; repercussions for rescuers $137-8$; rescuer recognition 129-31; sex and security 131-3; sharing 151-7; shift in women's roles 122-3; succeeding generations 136-7; summary and conclusions 139; thanks 134-5; see also Gacaca courts

Power, S. 2

power-sharing 24, 123

Powley, E. 27-8

print publications $41-5,51,52$

Pritchard, M. 7

Pro Femme Twese Hamwe 32

punishment 125-9

Queen Mothers 24, 28 see also Kanjogera

race, pseudoscience 26-7; see also

Hamitic myth

Rachel 51, 60, 68-9

radical history 23

radio $41,45-8,51,52-3,100$

Radio Télévision Libre des Mille Collines (RTLM) 41, 45-6, 51, 100, 101

rape $44,76,97-9$

Rebecca 154

recognition 123, 129-31

reconciliation: attitudes to 154 ; meaning of 156; requirements for 151

recruitment, Interahamwe 72-3

refugees $123,124-5$

religion: Catholic Church 30; Christian evangelism 23; Christianity 71; Islam 71; participants' 13; paternalism 28-9; rescuers 77-9; traditional 28-9

remorse 112-13 see also White Fathers

repercussions: for perpetrators $135-7$; for rescuers $137-8$

"Report on the situation of human rights in Rwanda" 8

rescuers 81-3; actions 59ff; choice 78; cost to 67-8; defining 16; dual identities 65; effects of education 82-3; failed attempts 67-9; fear 61, 130-1; fear of retribution 60-1; friendship 80; gender norms $72-7$; humanity $80-1$; imposters 134; individualism 59-60; justice 81; local knowledge 69-72; locating 60-1; motherhood 79; motivations 41, 77-83; narrative similarity $83-4$; overview 13 ; post-genocide recognition 129-31; poverty 135 ; religion $77-9$; repercussions for $137-8$; representation of 60 ; risks 61,77 ; role of husbands 73-6; self-blame 68-9; sense of 
community 80 ; sex issues $131-3$;

sharing 150; status as women $65,66,67$,

77 ; summary and conclusions 84 ; thanks

$134-5$; vulnerability $66-8,153$

researcher effect 13

researcher role 15

researchers, position of 96

responsibility, attribution and acceptance of 46

retribution, fear of $60-1$

reunification 156

revolution 195930

rhetoric, rescuer responses to 59

righteous, identification of 12,129

rights, need for inclusivity 162-3

risks, for rescuers 61,77

Rosanne 51, 78, 81, 133, 134-5

Rose 102, 103-4

royal court 24

royal family 24

Rusesabagina, P. 94

Rutarindwa 25

Ruth 62, 66, 75-6, 79, 80, 130-1, 135, 153

Rwabugira 25

Rwanda: Not So Innocent - When Women Become Killers 9, 33, 95

Rwandan Patriotic Front (RPF) 33, 34, 35, $42,43,49,51,52,53,63,72,76-7,130$, 131; post-genocide $123-4,125-7$

\section{Sally 113}

sampling 11-12, 15

Sandrart, G. 25

Sapir, E. 156

security, and sex 131-3

Seifert, R. 97-8

semi-structured interviews 13-14

sense of community 80

Sentama, E. 33, 110, 139

sex, and security see security, and sex

sexism 72

sharing: among survivors 153; as

behavioral norm 145; car crash story

151; context and overview 145-6; and

ethnicity 146-7; during genocide

148-50; national shelter program 152-3;

post-genocide 151-7; pre-genocide

146-8; significance of 151 ; summary and conclusions 157

Sharlach, L. 9, 40

Sjoberg, L. 7, 9-10, 111, 121

Skjelsbæk, I. 98

snakes 46, 50, 97

social structure $26-7$ solidarity camps 151-2

stability, fragility of 136

Statement of Views 30

Staub, E. 7, 44, 138

stereotypes 2, 7, 8, 26, 43-4, 138-9; see also typecasting

stigma 75

Straus, S. 8, 72, 110

studying silences 6-7

subordinate roles 8

Sula $71,83,154$

supernatural knowledge 71-2

survivor organizations 153

Survivors Fund (SURF) 153

Suzanne 1, 96-7

Sylvia 109, 126-7

tangible evidence, use of phrase 156

Tanya 104-5

targeting, of victims 76

Tec, N. 7

terminology 16, 46

thanks, rescuers 134-5

"The Manifesto of the Bahutu" 29-30

theft $148-50,153$

theoretical framework: comparative historical approach 10; context and overview 5; definitions 16-17; feminist theory $5-7,9,10-11$; identity 11 ; individual roles 7-10; methodology 11-15

threat, perceptions of 52

Tickner, J.A. 5

Tracy 102-3, 112-13

translation, quality of $14-15$

translators, role of 13

traumatization, perpetrators 137

triangulation 12,15

Truth and Reconciliation Commission, Sierra Leone 127

Tutsi, invasion 1990 33-4

Tutsi women: representation of 43-4; targeting 7

typecasting 7; see also stereotypes

ubupfura 77, 79

umuganda 72, 151, 152

uncomfortable knowledge 124

United Nations: Article 73 29; decolonization mission 29

United Nations Economic and Social Council 8

United States Agency for International Development (USAID) report 124 


\section{Index}

unity 154,156

upstanders 2,7

Urujeni, R. 163

U.S. Department of State, rescuer recognition 129

Uwasi, S. 95

"us vs. them" mentalities 11

Uwilingiyimana, A. 34

Valerie 97, 99

valorization, of groups 44

van Pelt, R.J. 60

Vanessa 102

Vansina, J. 24

violence: collective 99-100; direct 95, 96-9; indirect 95, 99-102;

normalization of 7; post-genocide 123;

women's 33; see also rape

violent social movements, women's participation 6

visibility 7

voluntary agency $102-5$

vulnerability: rescuers $66-8,153$; survivors 155

Wadley, J. 9

Waller, J. 7, 40

war, as liberation $44-5$

Weitzman, L. 9

Wendy $1,61,77-8,134$

White Fathers 25, 26, 27 see also religion women: exclusion 27-8, 32-3; gender norms 138-9; international aid 125; violence 33

women's groups 32,123-4

women's rights 32

women's roles, shift in 122-3

Works for General Interest (TIG) camps 91, 92-3

world wars 29 